\author{
UNIVERSIDADE DE BRASÍLIA (UnB) \\ PROGRAMA DE PÓS-GRADUAÇÃO EM PATOLOGIA MOLECULAR \\ FACULDADE DE MEDICINA (FM)
}

\title{
MECANISMOS MOLECULARES DAS PROTEÍNAS ACESSÓRIAS NEF E VPU RELACIONADOS À PATOGÊNESE DO HIV-1
}

MARCOS VINÍCIUS PEREIRA GONDIM

ORIENTADOR: ENRIQUE ROBERTO ARGAÑARAZ 
UNIVERSIDADE DE BRASÍLIA - UnB

PROGRAMA DE PÓS-GRADUAÇÃO EM PATOLOGIA MOLECULAR

FACULDADE DE MEDICINA- FM

\section{MECANISMOS MOLECULARES DAS PROTEÍNAS ACESSÓRIAS NEF E VPU RELACIONADOS À PATOGÊNESE DO HIV-1}

MARCOS VINÍCIUS PEREIRA GONDIM

ORIENTADOR: ENRIQUE ROBERTO ARGAÑARAZ CO-ORIENTADOS: MICHAEL MARTIN SCHINDLER

Tese apresentada ao Programa de Pós-Graduação em Patologia Molecular da Universidade de Brasília, como requisito parcial para obtenção do título de Doutor

Brasília, 02 de Março de 2015

UNIVERSIDADE DE BRASÍLIA - UnB

PROGRAMA DE PÓS-GRADUAÇÃO EM PATOLOGIA MOLECULAR

FACULDADE DE MEDICINA - FM 


\title{
MECANISMOS MOLECULARES DAS PROTEÍNAS ACESSÓRIAS NEF E VPU RELACIONADOS À PATOGÊNESE DO HIV-1
}

\author{
Banca Examinadora
}

Prof. Dr. Enrique Roberto Argañaraz (orientador) - Universidade de Brasília

Prof. Dr. Francisco de Assis Rocha Neves - Universidade de Brasília

Prof. Dr. Carlos André Ornelas Ricart - Universidade de Brasília

Prof. Dr. Robert Edward Pogue - Universidade Católica de Brasília

Prof. Dr. Gustavo Romero - Universidade de Brasília

Prof. Dr. Rinaldo Wellerson Pereira - Universidade Católica de Brasília 
"Para cada esforço disciplinado há uma retribuição múltipla."

Jim Rohn

"Se você não mudar a direção, terminará exatamente onde começou"

Antigo provérbio chinês 
Dedico este trabalho

Àqueles que sempre estiveram ao meu lado desde meu nascimento, aos meus amados pais, Anair e Éder. Obrigado pai por ser exemplo de persistência e me mostrar que a carreira acadêmica é o caminho para o sucesso pessoal. Agradeço a minha amada mãe, por ser meu maior exemplo de perseverança e sucesso, TE AMO! Obrigado aos dois por serem meus exemplos.

À minha esposa, Déborah, pela sua doçura e por ter abdicado tanto de sua vida para me seguir, apoiar nas minhas dúvidas, me alegrar nos momentos difíceis e sempre ajudar a me levantar quando caio. $\mathrm{E}$ o mais importante, muito obrigado por sempre me fazer sentir o homem mais amado e feliz do mundo.

Aos meus irmãos, Sarah e Raphael, e amigos por fazer meus dias mais felizes.

A todos meus familiares. 


\section{AGRADECIMENTOS}

$\checkmark$ Ao meu orientador e colega, Prof. Dr. Enrique Roberto Argañaraz, por estar sempre me pressionando, fazendo ver que minhas limitações estão onde eu quero que elas estejam, e que sempre posso melhorar. Por acreditar no meu trabalho e na minha capacidade, me proporcionando a oportunidade de abrir os meus horizontes e crescer tanto profissionalmente quanto espiritualmente. Pela grande chance de mostrar meu trabalho no exterior. Por se dedicar esses quase dois anos, também, ao meu ensino. A tudo isto e muito mais, meus sinceros e profundos agradecimentos. Obrigado professor.

$\checkmark$ Ao meu companheiro de churrasco, grande anfitrião, chefe singular, parceiro de trenó, o Prof. Dr. Michael Schindler do HelmHoltz Zentrum Munique-Alemanha, que me ensinou, acolheu, ajudou em momentos difíceis e me fez sentir em casa mesmo tão longe. vielen Dank mine Freund .

$\checkmark \grave{A}$ minha esposa amada por estar sempre do meu lado mesmo que isto tenha que muitas vezes abandonar os próprios interesses. Ter sempre compreendido e me apoiado a tomar as melhores decisões para o nosso futuro. Ter suportado as várias vezes que tivemos que estar separados fisicamente. Por sempre me receber com um sorriso e trazer alegria ao meu coração quando estou cabisbaixo, me fazendo sentir o homem mais feliz. Por atravessar o mundo e aceitar em cima de um altar estar sempre comigo. Te amo.

$\checkmark$ Aos meus pais e irmãos, esta família que esteve sempre do meu lado, nos bons e maus momentos, acompanhando e fazendo parte do meu crescimento como homem. A estes quem devo meu caráter e minha educação. Em especial, agradeço a minha mãe por me ensinar que o bom de viver é viver. Por ser uma vencedora e me ensinar o caminho para ser um vencedor. A vocês; mãe, pai, irmão e irmã. Muito obrigado pelo amor, carinho $e$ compreensão!

$\checkmark$ A todos os amigos que fiz no HelmHoltz Zentrum. Principalmente ao Stephan, Karen, Herwig, Kristin, Sacha, Markus e Ruth, que me acolheram tão e me trataram tão bem. Dank Kollegen.

$\checkmark$ À minha amada sogra, Jovânia de Oliveira, que tenho certeza está algum lugar muito 
melhor e finalmente descansando depois muita dor e luta. Sentimos muito a sua falta mamãe.

$\checkmark$ Aos meus familiares que sempre se lembraram de mim quando estava longe.

$\checkmark$ Aos meus amigos e padrinhos Shila e Thiago, pela presença em minha vida, pelo carinho e apoio. Obrigado amigos.

$\checkmark$ À minha querida amiga Lisa Minari, pelo apoio e preocupação.

$\checkmark$ Ao meu grande amigo Mikael, que tanto me ajudou e tantas memórias divertidas de dentro e fora do laboratório e do país.

$\checkmark$ Ao Prof. Dr. Bergmann Morais, pela oportunidade de obter o título de doutor e dar continuidade a minha jornada no caminho da ciência.

$\checkmark$ Enfim, a todos aqueles que de alguma forma me auxiliaram no desenvolvimento deste projeto. Meus sinceros agradecimentos. 


\section{PARTE I}




\section{Lista de Figuras}

Figura 1.1. Incidência mundial de indivíduos portadores de HIV no ano de 2012 .6

Figura 1.2. Estrutura da partícula viral do HIV-1. .11

Figura 1.3. Estrutura genômica do vírus da Imunodeficiência Humana (HIV-1) 11

Figura 1.4. Ciclo de replicação do vírus da Imunodeficiência Humana (HIV-1). .15

Figura 1.5. Mecanismos envolvidos na diminuição da expressão de CD4 da superfície da célula pelo HIV-1 .21

Figura 1.6. Localização de motivos funcionais na estrutura da proteína Nef do HIV-1 .22

Figura 1.7. Alinhamento de diferentes alelos da proteína Nef do HIV-1 e a localização de seus motivos funcionais. .24

Figura 3.1. Esquema de clonagem das sequências dos diferentes genes nos vetores de expressão pECFP/YFP. .39

Figura 3.2. Construção do vetor lentiviral pNL-SIN-PGK-EGFP-NEO. .41

Figura 3.3. Construção do vetor lentiviral pNL-SIN-PGK-EGFP-NEO-shRNA. .41

Figura 3.4. Estratégia para medir FRET por FACS .46

Figura 4.1. Confirmação da construção de vetores de expressão pECFP contendo as diferentes sequências correspondentes aos genes celulares. . .50

Figura 4.2. Expressão e localização celular de proteínas de fusão. .51 
Figura 4.3. Caracterização da interação entre as proteínas celulares e a proteína Nef Na7 por FRET.

Figura 4.4. Níveis de interação direta entre as proteínas celulares e a proteína Nef NL4.3 por \% de FRET.

Figura 4.5. Níveis de interação direta entre as proteínas celulares e a proteína Nef Mac239 por $\%$ de FRET. .56

Figura 4.6. Níveis de interação direta entre as proteínas celulares e a proteína celular CD4 por $\%$ de FRET. .57

Figura 4.7. Interação das proteínas celulares com os diferentes alelos de Nef. 61

Figura 4.8. Caracterização da localização celular das proteínas celulares parceiras de Nef na presença da variante Nef NA7 do HIV-1 .64

Figura 4.9. Caracterização da localização celular das proteínas celulares parceiras de Nef na presença da variante Nef NL4.3 do HIV-1. . .66

Figura 4.10. Caracterização da localização celular das proteínas celulares parceiras de Nef na presença da variante Nef Mac239 de SIV. .68

Figura 4.11. Caracterização da localização celular das proteínas celulares parceiras de Nef na presença do receptor de superfície celular CD4 70

Figura 4.12. Confirmação da construção de vetores lentivirais codificando RNAis contra diferentes proteínas celulares. .71

Figura 4.13. Bloqueio da expressão de proteínas celulares fusionadas a CFP mediante o uso de shRNA

Figura 4.14. Inibição da expressão endógena por shRNA de proteínas celulares envolvidas na degradação de CD4 mediada por Nef. 
Figura 4.15. Níveis de expressão do receptor CD4 em células Jurkat transduzidas com vetores lentivirais expressando shRNA.

Figura 4.16. Niveis de expressão de CD4 na presença de shRNAs contra diferentes proteínas celulares... .76

Figura 4.17. Nivies de expressão do receptor CD4 em diferentes linhas de celulas $\mathrm{T}$ e linfocitos de sangue periférico. .76

Figura 4.18. Niveis de expressão de MHC-I na presença de shRNAs contra diferentes proteínas celulares.

Figura 4.19. Degradação de CD4 e MHC-I pela proteína Nef em células transduzidas com shRNAs para diferentes proteínas celulares .78

Figure 4.20. Modulação de CD4 mediada pela proteína Nef em linfócitos CD4 positivos isolados .80 


\section{Lista de Tabelas}

Tabela 1.1. Relação dos genes do HIV-1 e algumas de suas funções.

Tabela 1.2. Descrição das interações entre Nef e proteínas celulares .25

Tabela 3.1. Sequências de primers para amplificação de proteínas celulares e alelos de Nef..

Tabela 3.2. Listagem de anticorpos .43

Tabela 4.1. Porcentagem de interações entre as proteínas celulares, os alelos de Nef e a proteína CD4, determinados por FRET. .59

Tabela 4.2. Relação dos alelos da proteína viral Nef previamente descritos serem moduladores dos receptores de superfície celular em PBMC e suas respectivas linhagens. . .60

Tabela 4.3. Níveis de interação/co-localização observados pela microscopia confocal..... .79 


\section{Sumário}

\section{CAPÍTULO 1. Introdução}

1.1. Síndrome da Imunodeficiência Adquirida......................................................................

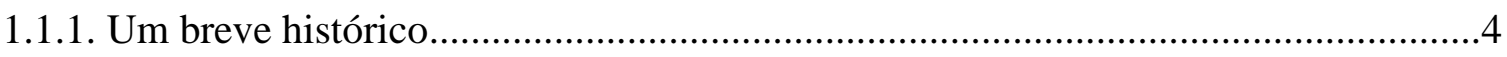

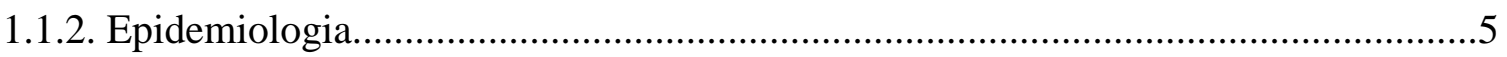

1.1.3. Perspectivas no controle da AIDS....................................................................6

1.2.Diagnóstico, Manifestações Clínicas e Tratamento..............................................................7

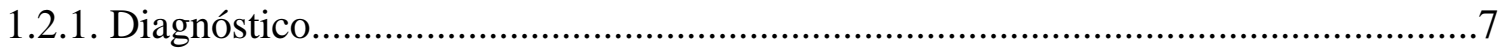

1.2.2. Manifestações Clínicas........................................................................................

1.2.3. Tratamento

1.3. O Vírus da Imunodeficiência Humana (HIV-1)..............................................................

1.3.1. Classificação Filogenética..................................................................................

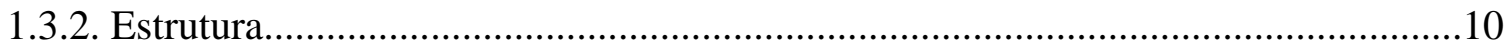

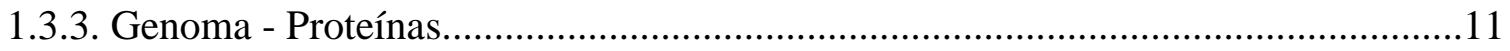

1.4. Ciclo de vida do HIV - "Uma extraordinária viagem pela célula" ....................................15

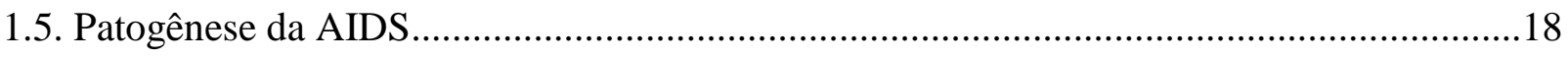

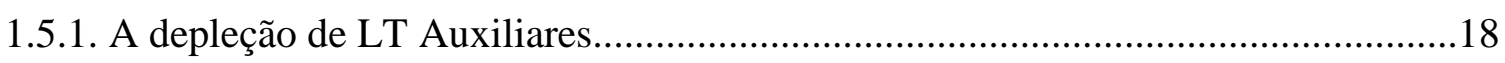

1.5.2. Diminuição da expressão do receptor viral CD4 e sua relevância na patogênese da

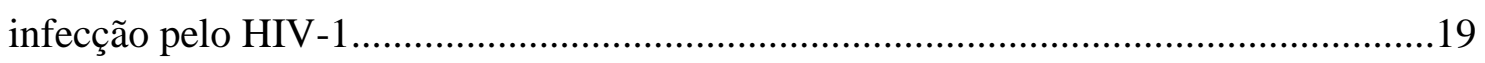

1.6. Estrutura de Nef e interação com as proteínas celulares....................................................22

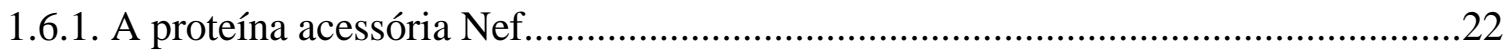

1.6.2. Os parceiros celulares de Nef na degradação de CD4.............................................24

1.6.2.1. A molécula de CD4 ..................................................................................26

1.6.2.2. As proteínas adaptadoras de complexos (APs).............................................27

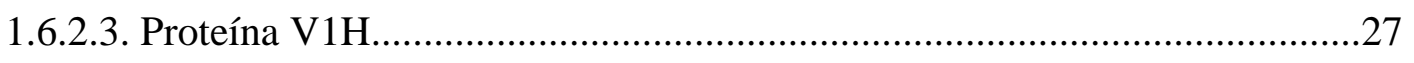

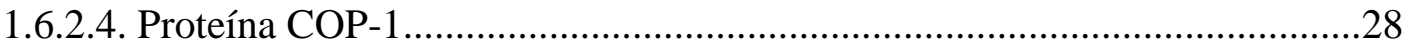

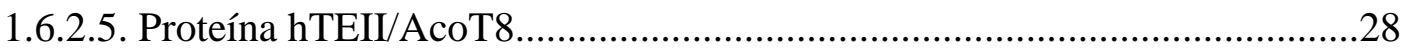

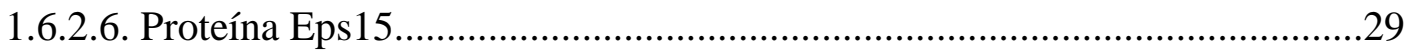

1.6.2.7. Proteína Dyn 2.......................................................................................29

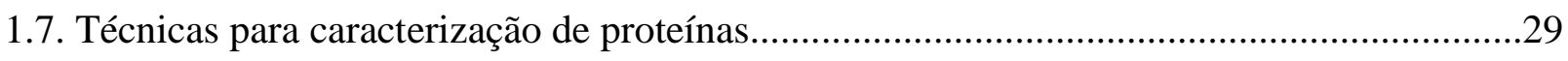

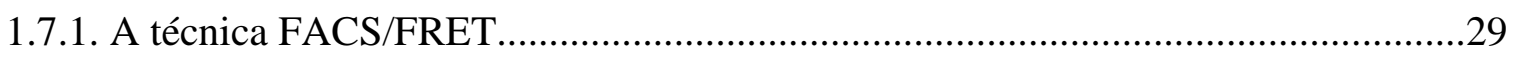

1.7.2. A técnica de RNA de interferência..................................................................... 


\section{CAPÍTULO 2. Relevância da Pesquisa e Objetivos}

2.1. Relevância da Pesquisa.

2.2. Objetivos

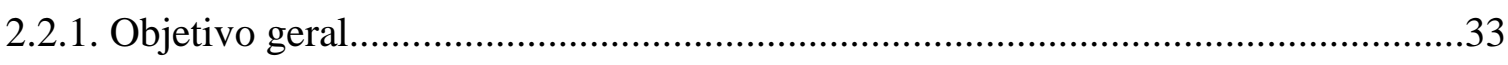

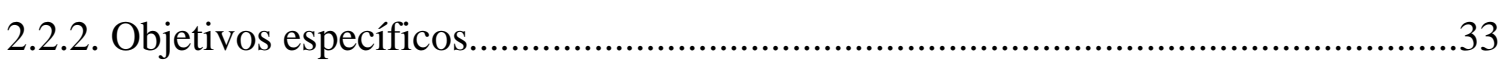

\section{CAPÍTULO 3. Materiais e Métodos}

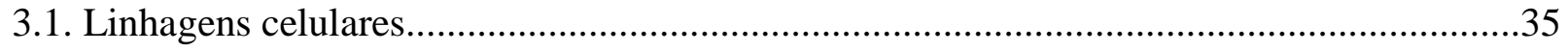

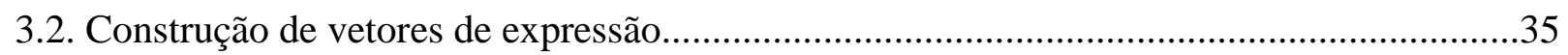

3.2.1. Desenvolvimento de vetores de fusão codificando proteínas celulares e alelos da

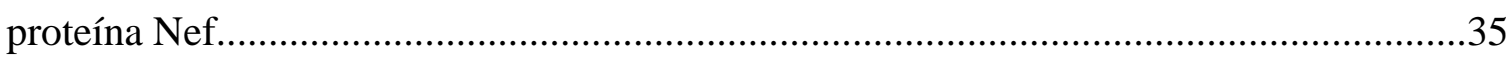

3.2.1.1. Reação de Polimerização em Cadeia (PCR)............................................. 35

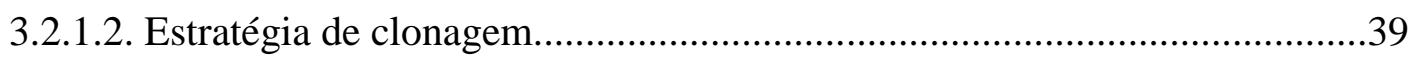

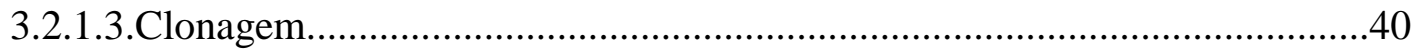

3.2.2. Desenvolvimento de vetores lentivirais codificando shRNA para proteínas

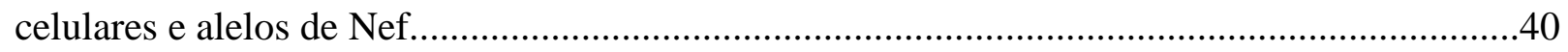

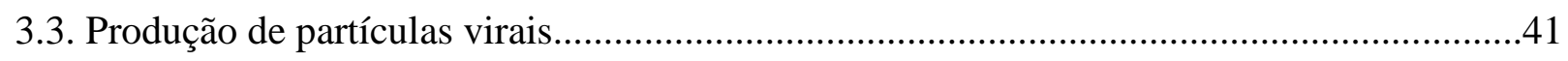

3.3.1. Transfecção de células e quantificação de partículas virais......................................41

3.4. Bloqueio da expressão gênica das proteínas celulares por shRNA.....................................41

3.4.1. Transdução de células........................................................................................41

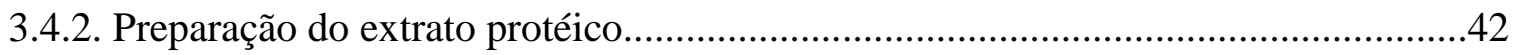

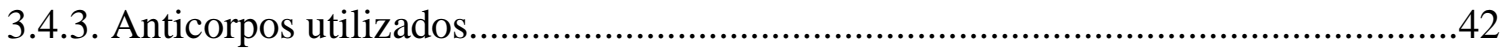

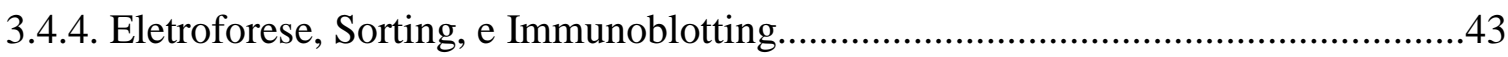

3.5. Avaliação da relevância fisiológica dos parceiros celulares de nef na modulação do

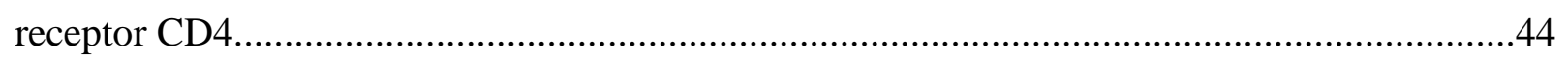

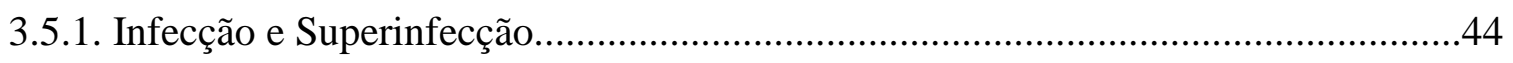

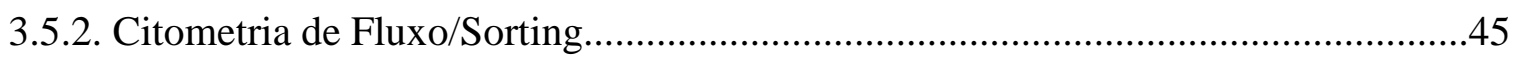

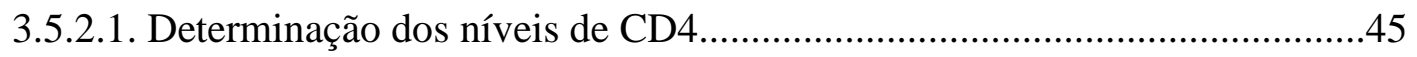

3.6. Frequência Ressoante de Energia Transferida - FRET ......................................................45

3.6.1. Transfecção de células para FRET ..................................................................... 45

3.6.2. Frequência Ressoante de Energia Transferida (FRET/FACS) ..............................46

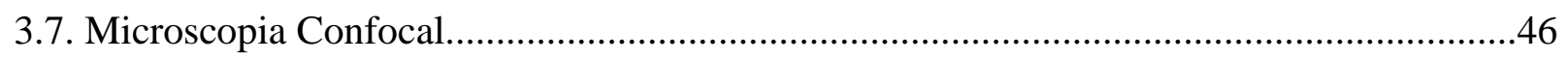

3.7.1. Transfecção de células para Microscopia Confocal...............................................46

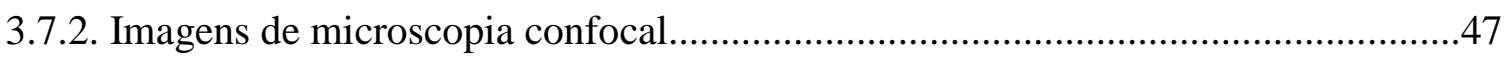




\section{CAPITULO 4. Resultados e Discussão}

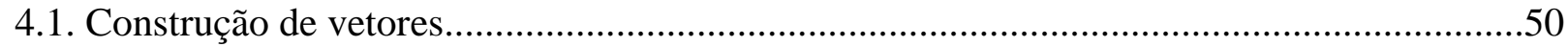

4.1.2. Construção de vetores de expressão de proteínas de fusão........................................50

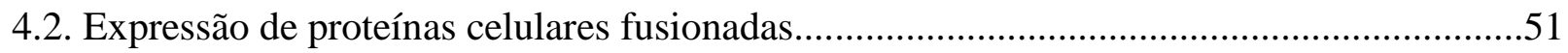

4.3. Caracterização da interação entre proteínas celulares e virais.............................................51

4.3.1. Interação entre proteínas celulares e o alelo NA7 da proteína Nef...........................52

4.3.2. Interação entre proteínas celulares e o alelo NL4.3 da proteína Nef........................53

4.3.3. Interação entre proteínas celulares e o alelo Mac239 da proteína Nef do SIV.........55

4.3.4. Interação entre proteínas celulares e o receptor CD4 ..............................................56

4.3.5. Identificação da interação de variatens humanas e não humanas de Nef- com as proteínas celulares que apresentaram direta interação com Nef..............................................60

4.4. Análise de co-localização das proteínas celulares por microscopia confocal.....................61

4.4.1. Caracterização de interação entre proteínas celulares e o alelo Nef NA7 por microscopia confocal.

4.4.2. Caracterização de interação entre proteínas celulares e o alelo Nef NL4.3 por microscopia confocal.

4.4.3. Caracterização de interação entre proteínas celulares e alelo Nef Mac239 por microscopia confocal.

4.4.3. Caracterização de interação entre proteínas celulares e o receptor CD4 por microscopia confocal.

4.5. Avaliação do bloqueio das proteínas celulares induzido por short hairpin RNA . .71

4.5.1. Construção dos vetores codificando short hairpin RNA de interferência................71

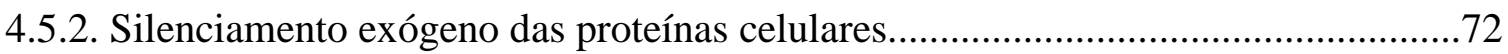

4.6. Produção de partículas virais, infecção e superinfecção....................................................72

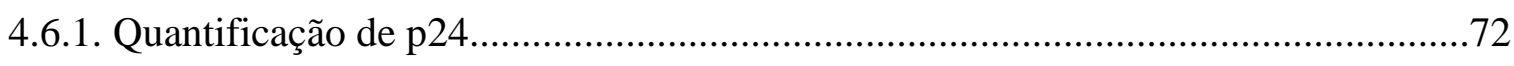

4.6.2. Silenciamento endógeno das proteínas celulares.................................................73

4.6.3. Relevância fisiológica de proteínas celulares na modulação do receptor CD4 mediada por Nef...

\section{CAPITUlO 5. Conclusões e Perspectivas}

5.1. Conclusões.

5.2. Perspectivas 


\section{Lista de Siglas e Abreviaturas}

AIDS - Síndrome da Imunodeficiência

AP1 $\sigma$ - proteína adaptadora 1 subunidade sigma

AP1 $\gamma$ - proteína adaptadora 1 subunidade gamma

AP $2 \mu$ - proteína adaptadora 2 subunidade mu AP2 $\sigma$ - proteína adaptadora 2 subunidade sigma

AP3 $\mu$ - proteína adaptadora 3 subunidade mu

ARV - AIDS - Associated Retrovirus

AZT - zidovudina

Bst-2/CD317/Theterin - Bone Marrow Stromal Antigen 2

CA - capsídeo

CD1d-Cluster of differentiation 1d

CD4 - Cluster of differentiation 4

DNA - ácido desoxirribonucléico

dsRNA - RNA de dupla fita

Dyn 2 - Dynamina 2

Eps 15 - Substrato de Crescimento Epidermal 15

FACS - Fluorescence activated cell sorting

FRET - Fösters resonance energy transfer gp120 - glicoproteína 120

TARV - Terapia Antiretroviral

Hck - kinase

HIV - Vírus da Imunodeficiência Humana

HIV-1 - Vírus da Imunodeficiência Humana tipo 1

HIV-2 - Vírus da Imunodeficiência Humana tipo 2

hTE/AcoT8 - Tioesterase humana II Humana
ICTV - International Committee on Taxonomy

of Viruses

IN - integrase

$\mathrm{Kb}$ - kilobases

$\mathrm{kDa}$ - kilodalton

LT - Linfócitos T

LTRs - Long Terminal Repeat Sequences

MHC-I/II - $\quad$ Complexo de

Histocompatibilidade do tipo I/II.

miRNA- Micro RNA

NTB-A - B cell antigen

NTK - Células natural killer

OMS - Organização Mundial da Saúde

$\mathrm{pb}$ - pares de base

PBMC - células mononucleares de sangue periférico

$\mathrm{PR}$ - protease

RE - retículo endoplasmático

RNA - ácido ribonucléico

RNAi - RNA de interferência

shRNA - Short Hairpin RNA

RNAm - RNA mensageiro

SDS - Sodium dodecylsulfate

siRNA - Pequenos RNAs de interferência

$\mathrm{V} 1 \mathrm{H}$ - proteína vacuolar 1 subunidade $\mathrm{H}$

SIV - Vírus da himunodefisciência simiana

Vpu - Proteina viral U

NFk-B - Fator de transcrição

$\beta$-COP - coatomer protein subunit beta 
PARTE I

Caracterização fisiológica de proteínas celulares na modulação do receptor celular CD4 mediada pela proteína viral Nef do Virus da Imunodeficiência Humana Tipo 1. 


\section{RESUMO}

A modulação de CD4 é uma das principais características da infecção por HIV e Nef desempenha um papel importante neste processo. Foi observada uma clara relação entre a degradação do receptor viral CD4, com o aumento da infecciosidade e a replicação viral, sugerindo a participação deste fenômeno na patogênese e progressão da infecção. No entanto, os mecanismos envolvidos na internalização e degradação de CD4 mediada por Nef não são totalmente compreendidas e diferentes proteínas celulares têm sido apontadas como importantes parceiros celulares de Nef. Nef agiria na superfície celular como um conector da cauda citoplasmática da molécula CD4, com membros do complexo adaptador heterotetramérico de clatrina, redirecionando a molécula CD4 para vesículas endocíticas. Uma bomba de prótons vacuolar (V-ATPase) e a proteína Epsn15 foram envolvidas no aumento da força de ligação Nef e a subunidade $\mu 2$ de AP-2. Com a finalidade de evitar a reciclagem de CD4 para a superfície celular, uma segunda conexão entre CD4 e a proteína $\beta$-COP é estabelecida por Nef, o que permitiria direcionar o receptor para degradação lisossômica. Adicionalmente, duas proteínas foram também envolvidas no mecanismo a tioesterase humana II (hTE-II/AcoT8) e a dinamina 2 (Dyn2). Entretanto experimentos para validar a relevância fisiológica dessas proteínas não foram conclusivos. Neste trabalho, pretendemos determinar a relevância fisiológica das proteínas: AP1, AP2, AP3, VH1 ATPase vacuolar, $\beta$-COP e AcoT8, na modulação de CD4 mediada por Nef, em linhas de células T e linfócitos T $\mathrm{CD}^{+}$de sangue periférico, infectados pelo HIV-1 . Primeiramente, análises de FRET-FACS entre alelos de Nef e as proteínas celulares apresentaram diferentes níveis de interação. O receptor CD4 mostrou variáveis níveis de interação com os alelos de Nef, NA7, NL4.3 e Mac239 (39\%, 15\% e 13\%, respectivamente) e uma forte interação com as proteínas Ap2, $\beta$-COP $(50,4 \%, 32 \%$ respectivamente). Por outro lado os alelos de Nef mostraram interagir principalmente com Ap2, $\beta$-COP e AcoT8, este ultimo apenas com o alelo NA7. Experimentos de microscopia confocal confirmaram os resultados obtidos por FACS-FRET mostrando em alguns casos alterações claras na localização subcelular destas proteínas. Finalmente, o silenciamento da expressão endógena das proteínas celulares na linha de célula T SupT-1 e em linfócitos primários $\mathrm{CD}^{+}$mostrou a proteína AP2 como sendo necessária e suficiente para a modulação de CD4 mediada por Nef.

Palavras-chave: Alelos Nef, FRET, HIV-1, Ap2, Diminuição da expressão de CD4, Patogênese CD4 


\begin{abstract}
Down-modulation of CD4 is one of the hallmarks of HIV infection and Nef plays a major role in this process. Has been observed a clear relation between the CD4 viral receptor degradation with the infectivity and viral replication, which suggest the high relevance of this mechanism during the pathology and infection progress. However, the exact mechanisms governing Nef mediated internalization and degradation of CD4, are incompletely understood and different cellular proteins have been suggested as key players. Nef would act on the cell surface as a connector in cytoplasmic tail of CD4 molecule with members of heterotetrameric clathrin adapter complex, redirecting the CD4 molecule for endocytic vesicles. Vacuolar proton pump (V-ATPase) and Epsn15 protein would be involved enhancing the strength binding of Nef on subunit $\mu 2$ of AP-2. In order to avoid recycling of CD4 to the cell surface, a second connection between CD4 and $\beta$-COP is established by Nef protein, which would direct the receptor to lysosomal degradation. Additionally, two proteins were also involved in the mechanism human thioesterase II (hTEII/AoT8) and dynamin 2 (DYN2). However experiments to validate the physiological relevance of these proteins were not conclusive. In this work, we aim to address the physiological relevance of AP1, AP2, AP3, VH1 vacuolar ATPase, $\beta$-COP and AcoT8 for Nef mediated down-modulation of CD4 receptor in T-cell lines, and infected primary isolated CD4 positive cells. First, FRET-FACS analyses with different Nef HIV-1 strains showed different levels of interaction. The receptor CD4 shown variable level of interaction with Nef alleles; NA7, NL4.3 and Mac239 (39\%, 15\% e 13\%, respectively) and a strong interaction with Ap2, $\beta$-COP (50,4\%, 32\% respectively). On other hand, the alleles shown interacts mainly with Ap2, $\beta$-COP, and AcoT8 (only with NA7 alleles). Confocal microscopy experiments confirmed FACS-FRET results showing clear changes in subcellular localization of these proteins. Finally, endogenous cellular proteins knock-down experiments by RNA interference in transduced SupT1 and primary lymphocyte $\mathrm{CD}^{+}{ }^{+}$cells showed AP2 protein as being necessary and sufficient for Nef CD4 down-modulation.
\end{abstract}

Key words: Nef alleles, FRET, HIV-1, Ap2, CD4 down-modulation, pathogenesis. 


\section{Capítulo 1. Introdução}




\subsection{Síndrome da Imunodeficiência Adquirida}

\subsubsection{Um breve histórico}

A Sindrome da imunodeficiência Adiquirida (Acquired Immune Deficiency Syndrome AIDS) é causada pelo vírus da imunodeficiência humana (Human Immunodeficiency Vírus HIV).

Os primeiros casos de infecção pelo HIV-1 foram relatados na década de 80 e associados principalmente ao homossexualismo masculino. Por outro lado, a progressão à síndrome era relacionada ao câncer Sarcoma de Kaposi (tumor no endotélio linfático), ou a uma série de outras doenças oportunistas que afetassem diretamente aqueles indivíduos infectados [1].

Os primeiros indícios de que a AIDS tinha como agente infeccioso um retrovírus, surgiram em 1983, quando um grupo de pesquisadores francês liderado por Luc Montainger no Instituto Pasteur em Paris isolou um vírus aparentemente novo. Esse vírus foi denominado de Lymphadenopaty Associated Virus (LAV) [2, 3]. Nessa mesma época, outro grupo de pesquisadores, dos Estados Unidos, liderado pelo pesquisador Robert Gallo, relatou o isolamento de um novo vírus que infectava as células $\mathrm{T}$, denominando de Human TLymphotropic Virus (HTLV), que receberia a designação de HTLV tipo III [4]. Posteriormente, foi descoberto que o vírus descrito pela equipe norte-americana era o mesmo descrito pelo grupo francês. Em 1984, Jay Levy e colaboradores conseguiram isolar o vírus de pacientes assintomáticos, sugerindo então, que se tratava de pacientes portadores, recebendo a denominação de retrovírus associado à AIDS (AIDS - Associated Retrovirus (ARV) [5]. Ainda em 1984, a relação do HIV como agente etiológico da AIDS foi aceita pela comunidade científica e médica [6], [2], [1] e em 1986, o Comitê Internacional de Taxonomia de Vírus (International Committee on Taxonomy of Viruses - ICTV), determinou que o vírus recebesse a designação de Vírus da Imunodeficiência Humana (HIV-1) [1, 7]. Nesse mesmo ano, outro vírus com características semelhantes, entretanto menos patogênico foi denominado de (HIV2). Também nesse ano foram criados testes comerciais para detecção do HIV (estratégia que diminuiu significativamente a transmissão do vírus por transfusão de sangue). Outros avanços importantes no tratamento da AIDS e com grande impacto no aumento das expectativas de vida e melhoria da qualidade de vida dos portadores de HIV-1, foram o descobrimento do AZT (1987) e o desenvolvimento da terapia antirretroviral altamente ativa (TARV) $(1995)[6,8][5]$.

A AIDS rapidamente alcançou proporções pandêmicas e a ocorrência em diferentes populações como; homens homossexuais ou heterossexuais, usuários de drogas, portadores de hemofilia, crianças e receptores de transfusões de sangue mostrou uma mesma forma de 
transmissão, por meio de fluídos corporais das pessoas sadias com as infectadas [9].

\subsubsection{Epidemiologia}

Segundo o reporte da Joint United Nations Programme on HIV/AIDS de novembro de 2013 a [10] no ano de 2012 mais de 1,7 milhões de pessoas vieram a óbito em decorrência da AIDS, sendo que no ano de 2011 foram relatados 2,5 milhões de novos casos e aproximadamente 34 milhões de pessoas encontravam-se infectadas [10]. A região da África Subsaariana apresenta a maior incidência de recém infectados do mundo, sendo estes em sua maioria de idade entre 15-49 anos [10].

No Brasil, o órgão responsável pela notificação e investigação de doenças e agravos que constam na lista nacional de doenças de notificação compulsória, dentre elas a AIDS, é o Sistema de Informação de Agravos de Notificação - SINAN. Segundo estimativas realizadas pelo Departamento de DST, Aids e Hepatites Virais aproximadamente 718 mil pessoas vivem com HIV/Aids no Brasil. Considerando os dados acumulados de 1980 a junho de 2013 no Brasil, foram notificados no Sinan, declarados no SIM e registrados no Siscel/Siclom um total de 686.478 casos de aids, dos quais 445.197 (64,9\%) são do sexo masculino e 241.223 $(35,1 \%)$ do sexo feminino. Do total de casos registrados entre 1980 e junho de 2013, 379.045 $(55,2 \%)$ são das seguintes regiões: Região Sudeste; 137.126 (20,0\%) da Região Sul; 95.516 $(13,9 \%)$ da Região Nordeste; 39.691 (5,8\%) da Região Centro-Oeste; e $35.100(5,1 \%)$ da Região Norte [11].

A prevalência da AIDS nos países mais populosos permanece relativamente baixa, mas em muitos deles, as condições para o surgimento de uma epidemia em grande escala já existe. Entretanto, nos países industrializados da América do Norte, Sul e Oeste Europeu, as características da epidemia mudaram, onde o índice baixo de prevalência associado ao acesso à terapia retroviral teve um impacto favorável, tanto na progressão como na mortalidade. Já nas minorias étnicas e populações pobres dentro destes países o impacto benéfico da terapia é menos pronunciado, onde a incidência da AIDS aumentou quando comparado com populações mais ricas [12]. Em alguns destes países, a transmissão heterossexual passou a ser a principal via de contaminação. Por outro lado, o acesso à terapia retroviral teve alguns efeitos contrários, já que se detectou um aumento na incidência devido a um tipo de comportamento chamado de "fadiga do sexo seguro" [13].

As vias de transmissão do HIV são diversas. O vírus pode ser transmitido por meio do contato com sangue e/ou secreções contaminadas, seja por intercurso sexual, transmissão 
vertical, pelo uso de seringas e agulhas contaminadas, ou por transfusão de sangue contaminado $[12,14]$. A transmissão pela via oral é pobremente entendida. Tem sido sugerido, que os riscos de transmissão oral seriam maiores do que previamente estimados, no entanto, a transmissão oral é de oito a dez vezes menos provável que a via vaginal ou retal [15]. Entretanto, estudos em macacos neonatos mostraram que a infecção por esta via parece ser bem mais frequente que em adultos $[16,17]$. Também foram detectados vírus na secreção lagrimal de pacientes infectados. Estima-se que mais de $90 \%$ das infecções em recém-nascidos e crianças são causadas pela transmissão perinatal [18], sendo que, em 2013, foi estimado que 800.000 crianças tivessem sido infectadas, antes ou durante o nascimento ou por meio da amamentação [10]. Sem tratamento, o risco da transmissão vertical é de aproximadamente $25 \%$ a 30\%, embora esta taxa de transmissão seja aumentada na África [19].

Outro dado preocupante, é que a AIDS tem aumentado significativamente entre as mulheres. Quase 60\% dos infectados com o HIV-1 são mulheres [20] despertando a necessidade em desenvolver vacinas, microbicidas e outras estratégias de prevenção para amenizar a propagação do HIV, principalmente nesses casos.

\section{CASOS REGIONAIS}

\begin{tabular}{|lr|}
\hline \multicolumn{2}{|c|}{ CASOS REGIONAIS } \\
\hline Tailandia & 780.000 \\
\hline Indonésia & 490.000 \\
\hline Leste Europeu & 380.000 \\
\hline Brasil & 1.400 .000 \\
\hline Estados Unidos da América & 490.000 \\
\hline Oriente Médio & 1.300 .000 \\
\hline Caribe & 300.000 \\
\hline Oceania & 230.000 \\
\hline Republica da Tanzânia & 53.000 \\
\hline África do Sul & 1.600 .000 \\
\hline Uganda & 5.600 .000 \\
\hline Moçambique & 1.400 .000 \\
\hline Nigéria & 1.400 .000 \\
\hline Zâmbia & 3.000 .000 \\
\hline
\end{tabular}




\begin{tabular}{|lr|}
\hline Etiópia & 790.000 \\
\hline Zimbábue & 1.200 .000 \\
\hline Quênia & 1.600 .000 \\
\hline
\end{tabular}

Figura 1.1. Incidência mundial de indivíduos portadores de HIV no ano de 2012[20].

\subsubsection{Perspectivas no controle da AIDS.}

Desde sua descoberta, a pandemia da AIDS continua excedendo todas as expectativas em severidade e impacto sócio-global deixou de ser uma epidemia para passar a ser considerada uma pandemia, e se, os números de novas infecções continuarem crescendo no mesmo ritmo, as consequências devastadoras observadas até aqui poderão ser mínimas, ao serem comparadas com as de um futuro próximo.

O desenvolvimento de novas drogas e estratégias para controle e redução do número de pessoas infectadas, se faz necessário e urgente. Em 2006, na XVI Conferência Internacional de AIDS, ficou claro que é necessário o empenho de toda população mundial para que possa se lograr o controle e até a cura desta síndrome.

Um dos grandes problemas no controle da AIDS está no surgimento de variantes resistentes aos inibidores presentes no coquetel antirretroviral, a permanência de reservatórios virais latentes, a presença de efeitos tóxicos colaterais causados pelo tratamento e o alto custo das drogas disponíveis no mercado. Dessa forma, a pesquisa de mecanismos básicos de patogênese volta a desempenhar um papel crucial na identificação de novos alvos farmacológicos e consequentemente no desenvolvimento de novas estratégias terapêuticas e de vacinas eficientes e seguras.

\subsection{Diagnóstico, Manifestações Clínicas e Tratamento}

\subsubsection{Diagnóstico}

O diagnóstico para detecção da infecção pelo HIV é realizado por meio de testes laboratoriais que envolvem a detecção de anticorpos por ensaio imunoenzimático (ELISA), entretanto, este exame pode ser reativo devido à alta sensibilidade do teste, fazendo-se necessário o uso de métodos mais específicos, como "western blotting", imunofluorescência e diagnóstico molecular, em caso de janela imunológica, como a reação de polimerização em cadeia (PCR) usada em pesquisas [5].

Os testes utilizados são incapazes de identificar pessoas recentemente infectadas, uma vez que após a infecção demora- se de 6 a 12 semanas para que haja a produção de anticorpos (soroconversão), período este denominado janela imunológica. Os testes utilizados apresentam geralmente níveis de até $95 \%$ de positividade nos primeiros seis meses após a infecção [10, 21]. 


\subsubsection{Manifestações clínicas}

A infecção pelo HIV pode ser dividida em dois diferentes estágios ou fases: fase aguda e fase crônica. Na fase aguda, que pode ser assintomática, a contagem de linfócitos T CD4 é superior a 500 células $/ \mathrm{mm}^{3}$. Quando presentes os sintomas, que só aparecem durante o pico de viremia e no início da resposta imunitária (apresentados em sintomas como; gripe, febre, linfoadenopatia causada pela dilatação dos gânglios linfáticos e linfonôdos, certa perda de peso, náusea, vômito e hepatoesplenomegalia decorrente pelo inchaço do baço e fígado provocada pelo aumento da atividade de defesa imonológica do organismo), é possível que também surjam doenças oportunistas como candidíase oral, meningoencefalite, tuberculose, pneumonia e síndrome de Guillain-Barré que consiste no ataque do sistema imunitário ao próprio sistema nervoso [5].

$\mathrm{Na}$ fase crônica ou tardia, a contagem de linfócitos T CD4 cai drasticamente entre 50 a 200 células $/ \mathrm{mm}^{3}$. Nessa fase os pacientes estão muito mais susceptíveis a infecções oportunistas causadas por vírus, bactérias, fungos e protozoários, como exemplos: pneumonia decorrente da infecção por Pneumocystis carinii, criptosporidíase, encefalite por Toxoplasma Gondii, e alguns tipos de neoplasia, como sarcoma de Kaposi e linfoma não Hodgkin, câncer nos gânglios [5].

A maioria dos pacientes infectados, dentro de um período de até 10 anos, progridem para um quadro clínico conhecido como AIDS, caracterizado este por uma profunda disfunção do sistema imunológico, levando a ocorrência de diversas doenças infecciosas oportunistas e por fim ao óbito em ausência de tratamento anti-retroviaral [22].

Um dos fatos mais intrigantes da infecção pelo HIV é que embora a maioria dos pacientes desenvolva AIDS, chamados de progressores (Prog) [23]. 2-5\% são aparentemente saudáveis e apresentam níveis estáveis de LT-CD4 ${ }^{+}$por uma década ou mais, sem tratamento antirretroviral [24]. Dentro deste grupo se encontram os pacientes não progressores de longo prazo (LTPN), e os controladores de elite (CE). Os LTPN são caracterizados por uma carga viral relativamente baixa $\left(<10,000\right.$ copies $/ \mathrm{mm}^{3}$ de plasma) e manutenção de níveis estáveis de células T $\mathrm{CD}^{+}\left(\geq 400 / \mathrm{mm}^{3}\right)$ durante pelo menos sete anos. No entanto, a progressão à doença pode ainda ocorrer em alguns destes pacientes [25, 26]. Já os CE representam uma pequena percentagem no grupo de LTNP (0,5 a $1 \%$ de pacientes HIV-positivos) e se caracterizam por uma carga viral $<50$ copies $/ \mathrm{mm}^{3}$ de plasma, e a concentração normal de LT-CD4 ${ }^{+}$, na ausência de tratamento [27-32]. Por outro lado, outros indivíduos, apesar de ter um comportamento de alto risco, são soro negativos mostrando serem resistentes a infecção [22]. 


\subsubsection{Tratamento}

O surgimento da terapia antirretroviral altamente ativa (TARV) proporcionou ao paciente drástica supressão da replicação viral, aumentando-lhe o tempo e a qualidade de vida. Atualmente, os diversos antirretrovirais licenciados têm como alvo molecular, principalmente, as enzimas transcriptase reversa (RT), protease (PR) e integrase (IN). Após o uso do coquetel antirretroviral por mais de uma década, o tratamento mostrou ter sérias limitações: ineficácia na erradicação da infecção, dada à persistência de reservatórios virais, o surgimento de variantes resistentes, devido a mutações e finalmente, por apresentar sérios efeitos colaterais, como alterações no metabolismo de lipídeos que redundam, em alguns casos, em acidentes cardiovasculares, lipodistrofia muscular e ainda alterações neurológicas [33, 34]. Dentro dessa nova realidade e graças aos novos conhecimentos trazidos pela pesquisa básica, novas drogas e abordagens terapêuticas estão sendo desenvolvidas.

Uma nova tendência no tratamento antirretroviral é a indução de resposta imunitária capaz de complementar o tratamento. Dessa forma, mediante o fenômeno chamado de "autoimunização", conseguido pela interrupção temporária da terapia, busca-se estimular a resposta imune específica em pacientes submetidos à terapia antirretroviral. Grande parte das mais promissoras drogas que estão sendo testadas em ensaios clínicos visa inibir a interação entre as proteínas virais e celulares. Estas drogas agem, basicamente, nos três diferentes estágios da entrada do vírus na célula hospedeira. As drogas mais promissoras são as que agem no último estágio, onde ocorre a fusão das membranas virais e celulares. A mais promissora, dentre elas, é o inibidor T-20 [35], que foi aprovado pela "US Food and Drug Administration".

Todavia, a implantação dessas novas drogas ainda esta em fase de teste e requer grandes investimentos por parte das companhias farmacêuticas e por parte dos consumidores destes produtos. Frente a isso, o desenvolvimento de novas formas de terapia faz-se necessário.

\subsection{O Vírus da Imunodeficiência Humana (HIV-1)}

\subsubsection{Classificação Filogenética}

O HIV-1 é um típico membro do gênero Lentivírus da família Retroviridae. O nome é derivado do latim Lente, uma referência ao longo período de incubação nos hospedeiros e sua capacidade de persistir e replicar-se por muitos anos, antes de causar sinais clínicos da doença.

Os Lentivírus apresentam como características principais: (i) causar efeitos citopáticos; (ii) provocar deficiências imunológicas, desordens hepáticas e nervosas; (iii) deixar o indivíduo susceptível a doenças autoimunes. Apresentam ainda contínua mutação viral e capacidade de integração de uma cópia do DNA viral no DNA do hospedeiro. O vírus passa a ser denominado 
provírus, após seu genoma ser integrado no genoma da célula hospedeira [36]. Trata-se de um vírus constituído de duas moléculas de RNA fita simples, e por ser um retrovírus, utiliza a enzima transcriptase reversa para a transcrição do RNA em DNA. Além de possuir características gerais dos retrovírus, como a presença dos genes estruturais, gag, pol e env, os Lentivírus codificam proteínas acessórias (Nef, Vif, Vpr e Vpu) e regulatórias (Tat e Rev) da replicação viral. A descoberta do HIV estimulou a caracterização de vários outros Lentivírus, como aqueles isolados de primatas não humanos, SIV ("simian immunodeficieny vírus”) [37], [38], [9].

A análise de diversas sequências isoladas do HIV-1 permitiu a distinção de três grandes grupos: M (major), O (outlier) e N (non M, non O) [9] [37]. Acredita-se que cada grupo seria resultado de um evento de transferência independente de lentivírus de primatas não humanos para humanos. No caso do HIV-1, teria ocorrido a transferência do vírus $\operatorname{SIV}_{\mathrm{cpz}}$ (chimpanzé) para seres humanos e oito linhagens de HIV-2 surgiram a partir da infecção por SIV $_{\mathrm{sm}}$ (sooty mangabeys). O grupo M do HIV-1 tem a maior prevalência entre os casos de AIDS no mundo, principalmente o subtipo B, o de maior prevalência também no Brasil (Morgado et al., 1998). O grupo major $(\mathrm{M})$ pode ser subdividido em subtipos A, B, C, D, E, F, G, H, J e K e suas formas recombinantes CRFs (circulating recombinant forms) [9].

\subsubsection{Estrutura}

O vírion ou partícula viral possui um diâmetro que varia entre 80 - $110 \mathrm{~nm}$, um genoma de aproximadamente 9,8 kb. As glicoproteínas do envelope viral, gp120 de superfície (SU) e gp41, a glicoproteína transmembrana (TM), são derivadas de um precursor gp160, que é clivado por uma protease celular. Na superfície do vírion, é possível detectar entre 7 e 14 spikes, trímeros de gp41-gp120, No interior do envelope, encontra-se outro envoltório, a matriz, que é constituído pela proteína p17. O capsídeo, que possui formato cônico é formado pela proteína p24, e no interior dele encontram-se as duas cópias do genoma de RNA fita simples, com polaridade positiva, formando o nucleocapsídeo. As enzimas virais transcriptase reversa (RT), integrase (IN) e protease (PR) proteina viral "R" (Vpr), Fator negativo (Nef), entre outras, também são encontradas dentro da partícula viral. Pode ocorrer ainda a presença de proteínas oriundas da célula hospedeira, como o MHC-II (MHC de classe 2) associado ao envelope e à ciclofilina a associada ao capsídeo (Figura 1.2) [39], [40]. 


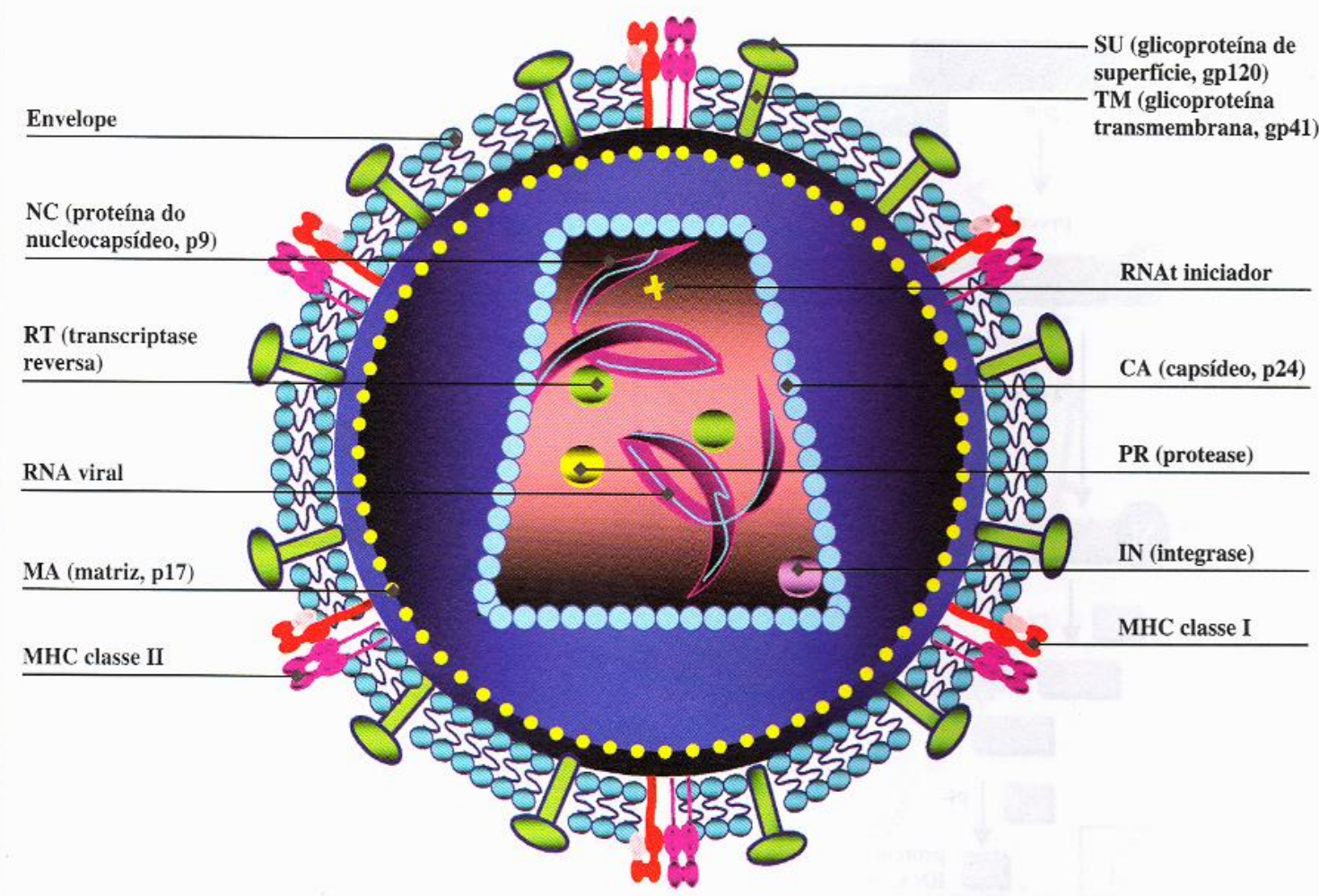

Figura 1.2. Estrutura da partícula vira do HIV-1. O HIV-1 é envolto por um envelope de natureza lipoprotéica. Em sua face interna, localiza-se a matriz, e na porção central da partícula viral, encontra-se o capsídeo com formato cônico. O genoma viral é constituído por duas fitas de RNA estabilizadas pelas proteínas do nucleocapsídeo. No interior do capsídeo, encontram-se as enzimas Protease (PR), Transcriptase Reversa (RT), Integrase (IN) e as proteínas (Nef, Vif e Vpr) [5].

\subsubsection{Genoma - Proteinas}

O genoma do HIV (Figura 1.3) é relativamente grande, apresentando um número maior de genes quando comparados a outros retrovírus [41].

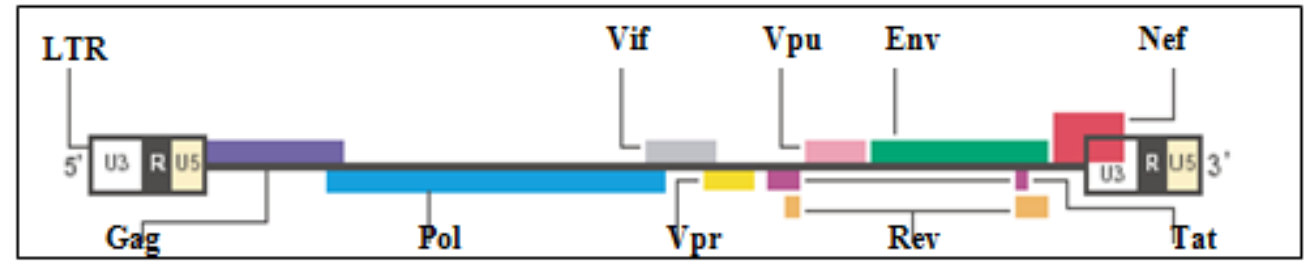

Figura 1.3. Estrutura genômica do vírus da Imunodeficiência Humana (HIV-1). Os genes gag, pol e Env (barras lilás, azul e verde respectivamente) codificam proteínas estruturais. Os genes Tat e Rev (barras roxas e laranjas respectivamente) codificam proteínas regulatórias. Os genes nef, vif, vpr e Vpu (barras vermelhas, cinzas, amarelas, rosas e azul claras, respectivamente) codificam proteínas acessórias. Nas terminações 3' e 5', encontram-se as sequências repetitivas longas, chamadas de LTRs [42].

O genoma do HIV-1 contém nove genes diferentes, sendo três deles comuns a todos os retrovírus: "gag" (que codifica as proteínas estruturais), "pol” (que codifica as enzimas virais protease (PR), transcriptase reversa (RT) e integrase (IN)), além de "env" (que codifica as glicoproteínas do envelope, gp120 e gp41). Esses genes são considerados estruturais. Os genes $g a g, p o l$ e Env são traduzidos em poliproteínas precursoras, que são posteriormente clivadas 
por proteases celulares e por uma protease viral [38], [9].

Diferentemente dos demais retrovírus, o genoma do HIV possui ainda os genes regulatórios, Tat e rev, além de quatro genes acessórios: nef, vif, vpr e vpu. Essa denominação de genes acessórios está baseada no fato de que as proteínas oriundas desses genes não são essenciais para a replicação do vírus in vitro, entretanto, desempenham importante papel in vivo, principalmente em relação a aspectos relacionados à evasão e manipulação da resposta imunológica adaptativa e inata [43].

O gene Gag é traduzido em uma poliproteína precursora de $55 \mathrm{kDa}$, denominada p55 Gag. Essa é clivada pela protease viral em quatro proteínas menores: p17, que forma a matriz; p24, que constitui o capsídeo; p7, que constitui o nucleocapsídeo; p6, que tem função de intermediar a incorporação da proteína Vpr aos "vírions"; e dois peptídeos espaçadores p1 e p2. Essas proteínas são encontradas nas partículas virais maduras do HIV-1 [44], [40].

O gene pol codifica uma poliproteína precursora das enzimas virais PR, RT e IN. A sequência do gene pol não possui um códon de iniciação. Assim, não pode ser traduzida de forma independente. As poliproteínas Pol e Gag são traduzidas de maneira fusionada, formando um precursor denominado Gag-Pol. A protease viral cliva o polipeptídeo Pol, separando-o de Gag, e, posteriormente, cliva Pol para gerar PR, RT e a IN. [40], [39], [9].

O gene Env codifica uma poliproteína precursora, que é sintetizada na forma de um trímero, com ligações não covalentes entre as subunidades gp120 e gp41 [38], [45].

O gene Tat codifica um transativador transcricional que é essencial à replicação do HIV 1. Tat é uma proteína originalmente descrita como um ativador do promotor LTR do HIV-1, tendo sido mostrada posteriormente sua capacidade de regular a transcrição reversa, o que afeta a expressão de vários genes celulares e virais. Tat liga-se ao RNA, reconhece uma sequência em forma de loop, denominada elemento de resposta à transativação (transactivation response element- TAR), localizada na extremidade 5' de todos os RNA's mensageiros do HIV-1. Algumas proteínas celulares ligam-se à TAR, dentre elas uma quinase, que fosforila componentes do complexo da RNA polimerase II. Como resultado dessa ligação, há o aumento na taxa de produção de transcritos virais primários de pelo menos 1000 vezes [40], [38], [9].

O transcrito completo do HIV possui múltiplos sítios de processamento alternativo (splicing). O processamento alternativo dos RNA's mensageiros é requerido para expressão eficiente dos genes virais. As proteínas Tat, Rev e Nef são processadas na fase inicial da infecção e acumulam-se devido à ativação transcricional produzida por Tat. O acúmulo da proteína $R e v$ é responsável pela mudança da fase inicial para a fase tardia do ciclo de replicação do HIV-1. Rev é uma proteína que se liga ao RNA e reconhece um elemento estrutural 
específico na região de $e n v$, denominado elemento de resposta à Rev (Rev-Response ElementRRE). Essa proteína ativa a exportação nuclear de transcritos não processados completos ou parcialmente processados, ou seja, que não sofreram processamento e contêm o elemento RRE. Dessa forma, Rev facilita a síntese das proteínas virais estruturais e garante a viabilidade do genoma completo de RNA do HIV-1. Rev também está envolvida no transporte dos transcritos de fase tardia dos genes $V p r, V p u$ e Vif para o citoplasma da célula hospedeira. No entanto, esses mRNAs só saem do núcleo após múltiplas cópias de $R E V$ ligarem-se nestes mRNAs [46], [40], [38], [39].

O gene nef (negative factor) originalmente recebeu esse nome devido à uma informação incorreta de que seria responsável por regular negativamente a transcrição dos vírus. No entanto, nef promove a persistência viral e leva a uma progressão mais rápida para a AIDS. Nef constitui-se numa proteína que interage com outras proteínas da célula hospedeira para facilitar sua resistência à ação do sistema imune e diretamente contribuir para a infectuosidade do vírus [47].Mais adiante serão abordadas por extenso as principais funções desta proteina por ser o alvo do estudo

A proteína viral $U$ ou $V p u$ é essencial à maturação e liberação das partículas virais. Da mesma forma que Vif e $V p r, V p u$ tem como alvo a degradação proteínas celulares da célula hospedeira, utilizando como via as ubiquitinas ligases [48], [49], [50]. Vpu também foi relatado estar diretamente relacionado na formação de canais iônicos em membranas celulares, com o objetivo de manter a homeostase iônica dentro e fora da célula [51]. Através desses atributos, ele antagoniza os fatores celulares capazes de restringir a liberação dos vírions nascentes das células infectadas. Um dado recente indica que um desses fatores de restrição celular é a proteína transmembrana BST-2/CD317 (Tetherin), que retêm vírions na superfície da célula [52], [53].

A proteína viral regulatória “R" ou VPR é incorporada à partícula viral pelo peptídeo p6 de Gag. Vpr foi caracterizada como um importante regulador de apoptose na célula infectada, existindo fortes evidências de que ela esteja envolvida na sobrevida viral e progressão à AIDS. Entretanto, esta proteína desempenha outras funções vitais ao ciclo viral, tais como: (i) aumento da eficiência do processo de transcrição reversa; (ii) transativação do promotor do HIV-1 (long-terminal repeat, LTR); (iii) facilitação da importação do complexo de préintegração viral (PIC); (iv) interrupção do ciclo celular no estágio $\mathrm{G}_{2}$ e modulação da sinalização do receptor de célula T (TCR) (T-cell receptor). [54], [55].

A proteína viral Vif, fator de infectuosidade viral (viral infective factor), tem papel importante na infecção e na replicação do vírus em células não permissivas, sendo essencial 
para infecções in vivo. A principal função de Vif é neutralizar a atividade antiviral de membros da família de citidina deaminases celulares, APOBEC3B, APOBEC3F e APOBEC3G. Na ausência de Vif, APOEBEC3G é empacotado nos vírions, resultando na deaminação de citidina em uracila durante a replicação viral, culminando na produção de provírus não funcionais [56], [57].

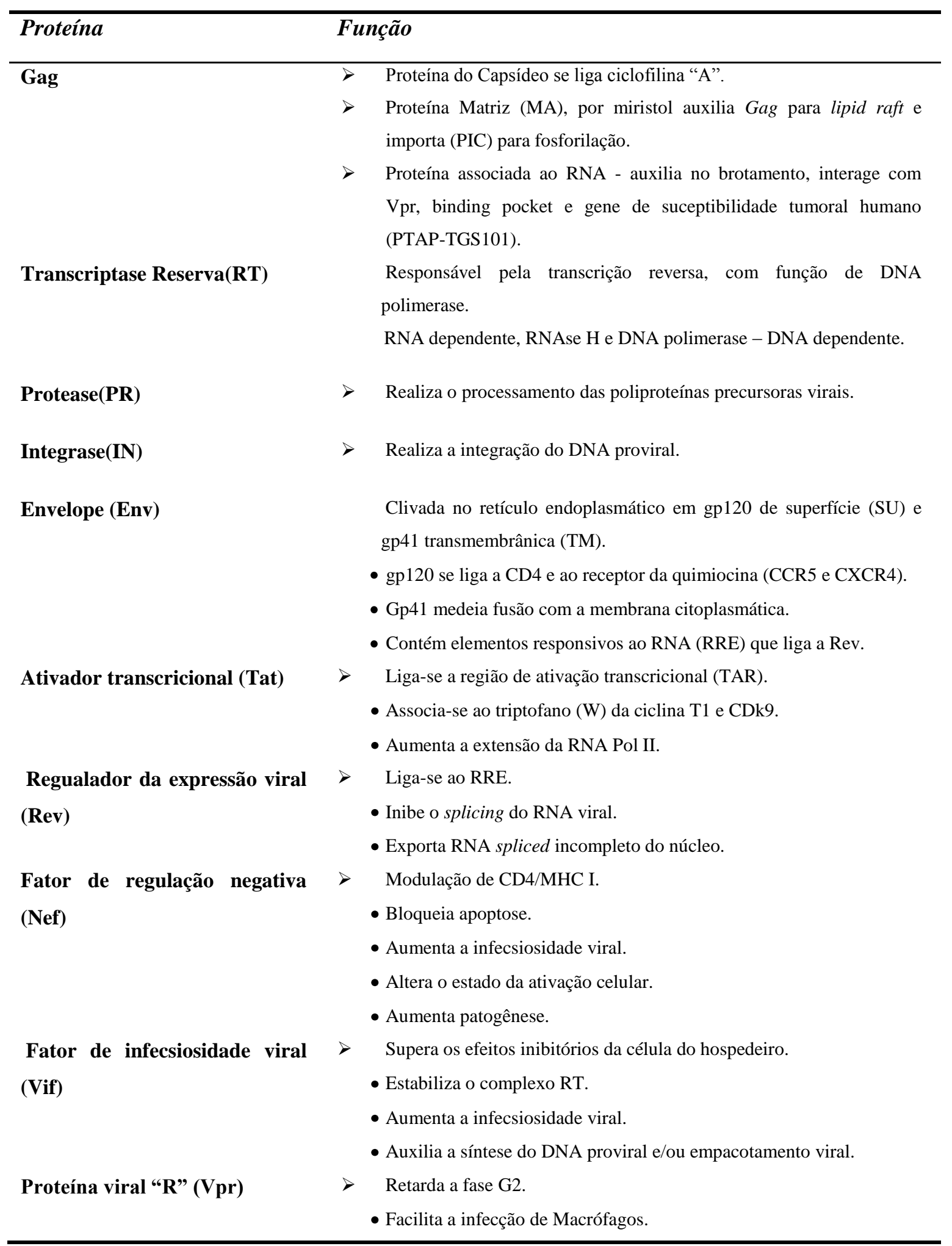




\begin{tabular}{lll}
\hline Proteína viral "U" (Vpu) & Promove a degradação de CD4/BST-2. \\
& $\bullet$ Auxilia a liberação do vírus. \\
Proteína viral "X" (Vpx) & $>\quad$ Auxilia na infecção \\
\hline
\end{tabular}

Tabela 1.1. Relação dos genes do HIV-1 e algumas de suas funções.

\subsection{Ciclo de vida do HIV - "Uma extraordinária viagem pela célula"}

Da mesma maneira que outros vírus, o HIV replica-se dentro da célula do hospedeiro para garantir sua permanência no mesmo. Para que isso ocorra, precisa passar por um longo caminho desde sua entrada até o núcleo da célula alvo, onde integrará seu material genético (Figura 1.4).

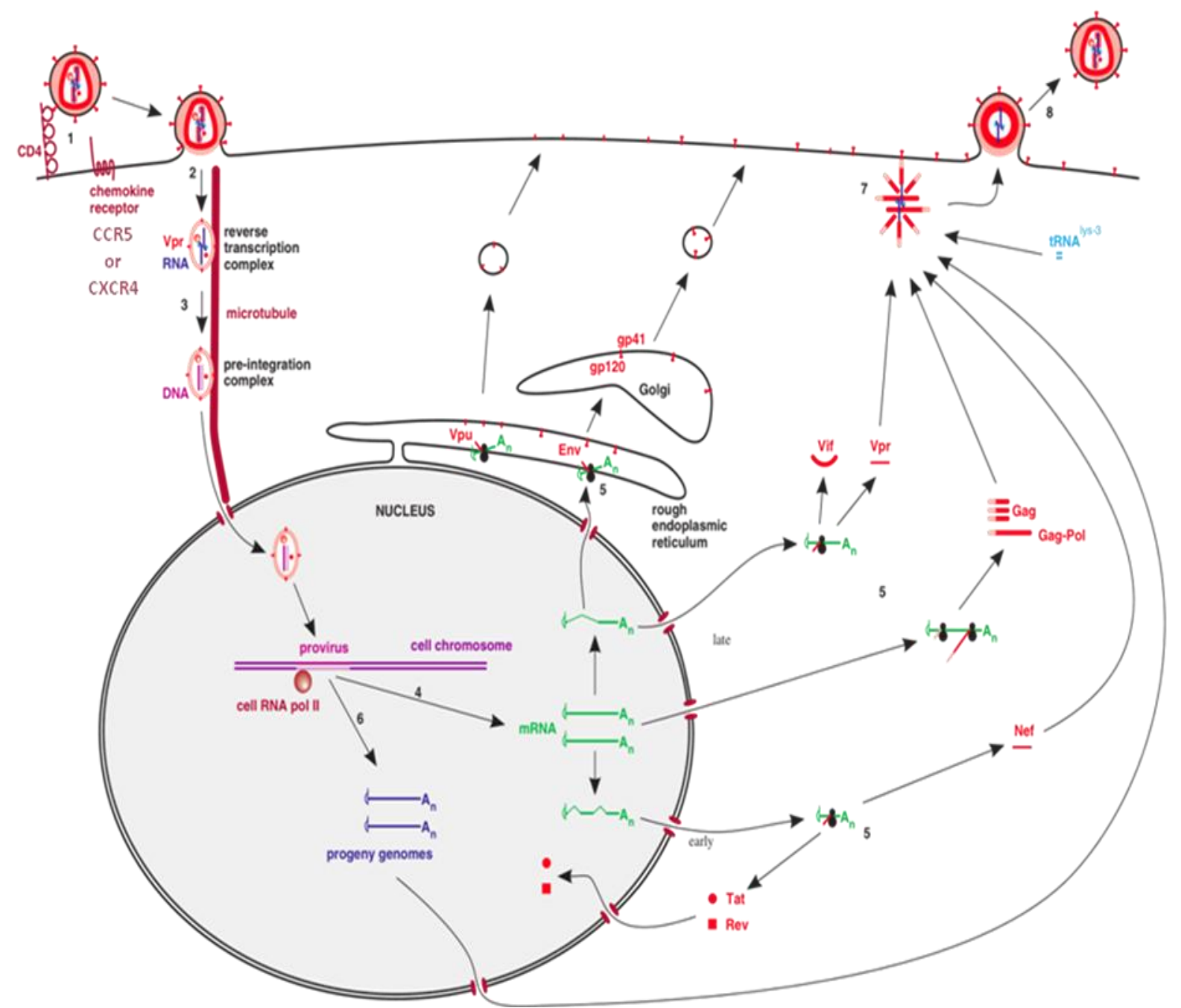

Figura 1.4. Ciclo de replicação do vírus da Imunodeficiência Humana (HIV-1) [58].

\section{1-Ancoramento}

2-Entrada 


\section{3-Transcrição reversa}

\section{1-Integração}

4-transcrição

5-Tradução

6-Replicação do genoma viral

7-Montagem da partícula viral

8-Saída

A infecção da célula hospedeira inicia-se pelo reconhecimento do receptor CD4 pela glicoproteína de superfície do vírus, gp120. Em seguida, como consequência de mudanças conformacionais induzidas pela ligação CD4-gp120, outra glicoproteína também presente na superfície viral, a gp41, reconhece um correceptor, um dos receptores de quimiocinas CCR5 ou CXCR4, e esse processo resulta na fusão de ambas as membranas [59]. A fusão permite que o capsídeo viral alcance o citoplasma. A maioria das linhagens do HIV-1 usa CCR5 como correceptor, sendo conhecidos como vírus R5. Infectam preferencialmente macrófagos e não induzem a formação de sincícios. As linhagens de vírus que usam o co-receptor CXCR4 são conhecidas como vírus X4 e infectam principalmente linfócitos, induzindo a formação de sincícios, que está vinculada a progressão acelerada da doença onde a alça da gp120 pode originar células gigantes multinucleadas que podem gerar grandes quantidades de vírus antes da morte celular. O receptor de quimiocina CCR5 encontra-se na superfície das principais células alvo, como LT CD4 ${ }^{+}$, macrófagos e células dendríticas e o co-receptor CXCR4 é encontrado em linfócitos [60], [58]. Em metade das infecções causadas pelo vírus do subtipo B, o surgimento do co-receptor CXCR4 está associado à progressão da doença [61].

Uma vez dentro da célula, o vírus abre o capsídeo, por um processo pouco entendido, mas que provavelmente envolve proteínas celulares e virais, como a ciclofilina “A” [62], Nef e Vif [63], [64]. Logo depois, forma-se um complexo, que recebe o nome de complexo de préintegração (PIC), o qual compreende as moléculas de RNA viral, molécula de tRNA ${ }^{\text {Lys-3 }}$ e as proteínas virais: transcriptase reversa, integrase, matriz, nucleocapsídeo, Vpr, Vif e duas proteínas do hospedeiro, HMGI (Y) e a barreira de autointegração (BAF), que se ligam ao DNA viral e auxiliam na sua integração [65], [66]. A RT viral é a responsável pela síntese do DNA dupla fita do vírus.

O PIC se move em direção ao núcleo usando a rede de microtúbulos da célula. Neste processo, a interação de Nef com a proteína celular Vav (um fator de intercâmbio de guanina) ou GEF (guanine nucleotide exchange factor) desencadearia uma série de funções efetoras, culminando com o reordenamento do citoesqueleto e consequentemente facilitando a migração 
do PIC para o núcleo [67], [68]. Uma vez na vizinhança do núcleo, o PIC deve enfrentar outro obstáculo, atravessar um poro nuclear significante menor que o seu tamanho. Neste processo, algumas proteínas virais teriam um papel chave, como a proteína viral MA (matriz), que está envolvida neste fenômeno, caracterizando assim um sinal de localização nuclear (NLS), que é reconhecido pelas importinas a e b, as quais fazem parte da via clássica de importação de proteínas para o núcleo.

Após passar por todos esses obstáculos, o DNA proviral se integra em diferentes locais no genoma do hospedeiro, podendo levar a um estado de latência ou de replicação, dependendo do local e da disponibilidade de fatores transcricionais. A integração eficaz do DNA viral dentro do cromossomo, em regiões próximas a genes ativos após a infecção pelo HIV, é mediada pelos integrantes do PIC, citados anteriormente (proteína viral IN e duas proteínas celulares identificadas, como HMGI(Y) e a barreira da autointegração (BAF) [69]. Os provírus da maioria dos retrovírus são constituídos por uma dupla fita de DNA. Mas como outros lentivírus o HIV também possue uma estrutura conhecida como DNA flap, que consiste na formação de um domínio triplo-helicoidal no DNA durante o processo de transcrição reversa e foi descrito como um importante fator na migração do PIC, com papel vital nos estágios iniciais de infecção [70] [39].

A transcrição do DNA viral é dirigida pelo 5' LTR (long terminal repeat), o qual possui sequências promotoras e sítios de ligação a fatores de transcrição, incluindo AP-1 e Sp-1. Upstream a essas sequências são encontrados sítios para a ligação de outros fatores como NF$\kappa \beta$ e NFAT. Uma transcrição eficiente é promovida após a ligação da proteína viral Tat com uma sequência localizada em LTR, que recebe o nome de TAR (Tat Activating Region). Essa, por sua vez, possui um sítio de interação com a ciclina T. Tat também se liga a ciclina T, e então a proteína quinase Cdk9 é recrutada e interage com a ciclina T. Essa interação ativa Cdk9, que hiperfosforila o domínio C-terminal da RNA polimerase II, aumentando a elongação dos transcritos virais do HIV-1 [71]. Tat liga-se aos transcritos nascentes e garante que todo o genoma do vírus seja transcrito. Rev liga-se ao RNA viral que sofreu "splicing" incompleto e ao RNA que não sofreu "splicing” e auxilia seu transporte para o citoplasma, enquanto as proteínas virais tardias são traduzidas. Rev é reciclado para ser utilizado novamente no núcleo [39]. A transcrição do genoma viral gera vários transcritos primários, alguns como os codificantes para Tat, Nef e Rev, os quais são processados na ausência de sequências inibitórias de RNA de "splicing” e são transportados para o citoplasma [72]. Outros são processados de forma incompleta ou não são processados, devido à carência de sítios de "splicing" nos transcritos, e a efeitos inibitórios da proteína viral Rev, que interage com alguns fatores 
celulares [73]. Estes transcritos codificam algumas proteínas estruturais e proporcionam o genoma viral necessário para ser empacotado dentro do capsídeo. Dessa forma, o equilíbrio entre estes dois mecanismos, "splicing" total e parcial, é requerido para a propagação da infecção.

Alguns genes virais apresentam expressão na fase tardia de replicação do vírus, como Gag e a poliproteína Gag-Pol, traduzidos a partir de transcritos que não sofreram "splicing”. As demais proteínas virais (Vif, Vpr, Vpu e Env) são traduzidas com base em transcritos que sofreram processo de "splicing" de maneira independente. Env e Vpu são traduzidos no retículo endoplasmático rugoso.

Os vírions são montados no citoplasma da célula hospedeira e têm como principais componentes as proteínas virais Nef, Vpr, Vif, TR e IN, além de um dímero de RNA. Moléculas de Gag e Gag-Pol formam um arranjo ordenado, e seus domínios ligam-se ao genoma do vírus e em proteínas que serão incorporadas aos vírions "nascentes". Os domínios básicos do núcleo capsídeo (NC) ligam-se ao genoma viral, inicialmente em um domínio conhecido como $\psi$, que é essencial no sinal de "empacotamento". Os domínios do CA ligam-se a proteína da célula hospedeira ciclofilina A, enquanto a região p6 de Gag liga-se a proteína viral Vpr.

Após a formação do dímero Gag-Pol, a protease sofre um processo autocatalítico de clivagem para a formação das enzimas virais PR, RT e a IN. Em seguida, a protease cliva as poliproteínas de Gag nos constituintes dos vírions maduros. Após o recrutamento de proteínas celulares, relacionadas com a formação dos corpos multivesiculares (MVBs), a particular viral utiliza a via de exocitose para formar vesículas intraluminais [74], o que culmina no brotamento das partículas virais englobadas em uma porção da membrana plasmática da célula.

\subsection{Patogênese da AIDS}

\subsubsection{A depleção de LT Auxiliares}

Logo após a descoberta da AIDS em 1981, ficou evidente que o número de LT-CD4 ${ }^{+}$ decrescia à medida que a infecção progredia [75]. Entretanto, quase 32 anos depois e apesar dos enormes esforços realizados pela comunidade científica, os motivos para tal depleção e o porquê do HIV evoluir para a síndrome continuam sendo motivos das mais diversas especulações e hipóteses.

$\mathrm{O}$ mecanismo patogênico direto, onde a perda dos LT-CD4 ${ }^{+}$ocorreria devido à lise ocasionada pela infecção [76] encontra-se praticamente descartada desde que a quantidade de linfócitos infectados na periferia não superaria o $10 \%$. Entretanto, Douek e colaboradores [77], demonstraram que os LT-CD4 ${ }^{+}$específicos para o HIV-1, são preferencialmente infectados, 
apoiado pela descoberta de uma maior frequência de DNA proviral integrado em LT-CD4 ${ }^{+}$de memórias específicas para epítopos do vírus, que o presente em linfócitos de memória com outras especificidades. Este estudo proporciona uma possível explicação para a perda de LTCD4 ${ }^{+}$HIV específico e consequentemente para a perda do controle da infecção [77].

Uma hipótese bastante aceita sugere que a depleção de LT-CD4 obedeceria a uma resposta exagerada e descontrolada do sistema imune, uma ativação policlonal especifica. Este tipo de resposta seria induzida pela transposição para corrente sanguínea de antígenos presentes no trato intestinal, fato este devido a destruição - morte da população de linfócitos localizados na parede intestinal como consequência de um efeito direto da infecção viral [78]. Este estado de ativação persistente redundaria a uma total exaustão do sistema imunitário.

Torna-se cada vez mais claro que os aspectos pró-inflamatórios desta resposta podem ser prejudiciais. Assim, muito provavelmente, a crescente ativação contribui diretamente para depleção das células $\mathrm{CD}^{+}$, talvez como uma consequência da exaustão e acelerado "envelhecimento" do sistema imune [79] e[80]. Curiosamente, Emu e colaboradores (2005), sugerem que o controle virológico está associado à preservação da produção de duas citocinas, IFN- $\gamma$ e IL-2, produzidas por LT-HIV específico, mas incompletamente diferenciados e com baixos níveis de proliferação. Esse estado imunológico pode ser definido, como um estágio em que o sistema imune mantém a capacidade de responder ao HIV se expandindo, pela ação da IL-2, mas não chegando a se exaurir, ou seja, se manteria num estágio relativamente quiescente. Esses dados trazem um novo paradigma na regulação da resposta imune, onde a produção de IL-2 pode ser benéfica, já que diminuiria os níveis de reposição dos "LT naive". Este novo modelo encontra sustentação no trabalho de Sereti e colaboradores [81], onde, a administração da IL-2 levou a um aumento no número de células $\mathrm{T}$ foxP3 ${ }^{+}$, o que poderia exercer uma leve supressão da ativação policlonal de "LT naive"[82].

Finalmente, recente evidencia aponta ao nível de infecção de linfócitos central de memoria central (TCM) e linfócitos "stem cell" de memoria (TSCM) como responsáveis dos diferentes graus de progressão observados entre os pacientes HIV positivos [83]. Assim o controle da viremia na fase crônica requereria a preservação do "pool" de LT de memória, mas em ausência de ativação generalizada.

Neste cenário, diversas evidências obtidas nos últimos anos ajudaram a melhorar o entendimento dos possíveis mecanismos que levam à depleção do sistema imune.

1.5.2. Diminuição da expressão do receptor viral CD4 e sua relevância na patogênese da infecção pelo $\mathrm{HIV-1}$ 
O HIV-1 se liga ao receptor CD4 presente na superfície de linfócitos e macrófagos através da glicoproteína gp120 presente no envelope do HIV-1. Após a interação com CD4 a gp120 sofre mudanças conformacionais que culminam na fusão das membranas virais e celulares [84], [85]. Momentos após o evento de entrada viral, vários processos são iniciados com o objetivo de assegurar a integração do genoma pró-viral e consequente produção de partículas virais infecciosas. Dentro deste contexto a diminuição da expressão do receptor viral CD4 é um dos mais importantes eventos durante a infecção pelo HIV-1, sendo conservada tanto no HIV-1, HIV-2, como no SIV[86], [87].

Dentre os nove genes virais, três deles: nef, Env e Vpu participam deste processo, demonstrando que a modulação do receptor viral da superfície celular possui papel crítico no ciclo de replicação destes retrovírus. De fato, níveis de CD4 levemente superiores aos observados nos linfócitos primários podem vir a saturar a maquinaria viral [88]. Destas três proteínas, Nef é a única empacotada no vírion e expressa logo após a infecção, sendo seus transcritos os mais abundantes nesta fase, desempenhando o papel mais relevante na modulação de CD4[89], [90]. Assim, seu efeito pode ser detectado entre 12 a 16 horas após a infecção [88], porém a contribuição de Env e Vpu na modulação de CD4 é detectada apenas em estágios tardios da infecção [91].

Os efeitos de Nef (produto inicial) e Vpu/Env (produtos tardio) são quantitativa e qualitativamente distintos [90]. A modulação de CD4 (Figura 1.5) acontece em três diferentes níveis e localizações: na membrana plasmática, no retículo endoplasmático (ER) e em menor grau no aparelho de Golgi. Na membrana, Nef agiria como conector ligando o domínio citoplasmático do receptor viral CD4 ao complexo heterotetramérico adaptador de clatrina, AP2 [92]. Essa interação levaria à formação de vesículas endocíticas, que são direcionadas para o endossoma [93], [94] e posteriormente para degradação lisossômica via interação com outras proteínas celulares como $\beta$-COP e proteínas adaptadoras de clatrina (AP-1 e AP-3) [95]. Também foi proposto que Nef direcionaria as moléculas de CD4 presentes no trans-Golgi para os endossomas iniciais e tardios por meio de interações com as subunidades gamma $(\gamma)$ e mu $(\mu)$, reespectivamente, dos complexos AP-1 e AP-3, contribuindo assim com a degradação de proteínas recêm sintetizadas [94], [96] e [97].

As outras duas proteínas virais, $V p u$ e Env, agem no reticulo endoplasmático bloqueando o transporte das moléculas recém- sintetizadas. No entanto, devido à sua alta afinidade, a gp160 liga-se fortemente à molécula CD4 proporcionando a formação de agregados que bloqueiam o transporte do receptor viral para a superfície celular propiciando uma degradação com perda para ambas as partes, viral e celular [98], [99]. 
Posteriormente, $V p u$ que é uma proteína viral muito conservada entre os diversos isolados virais, mas ausente em HIV-2 e na maioria dos vírus da imunodeficiência simiana (SIV) [100], age de forma similar a Nef, como conector entre o domínio citoplasmático de CD4 e a proteína $\beta \operatorname{TrCP}$, membro do complexo protéico de ubiquitinação, Skp1p-CDc53-F-boxE3, que direciona o CD4 para a degradação proteassômica [48].

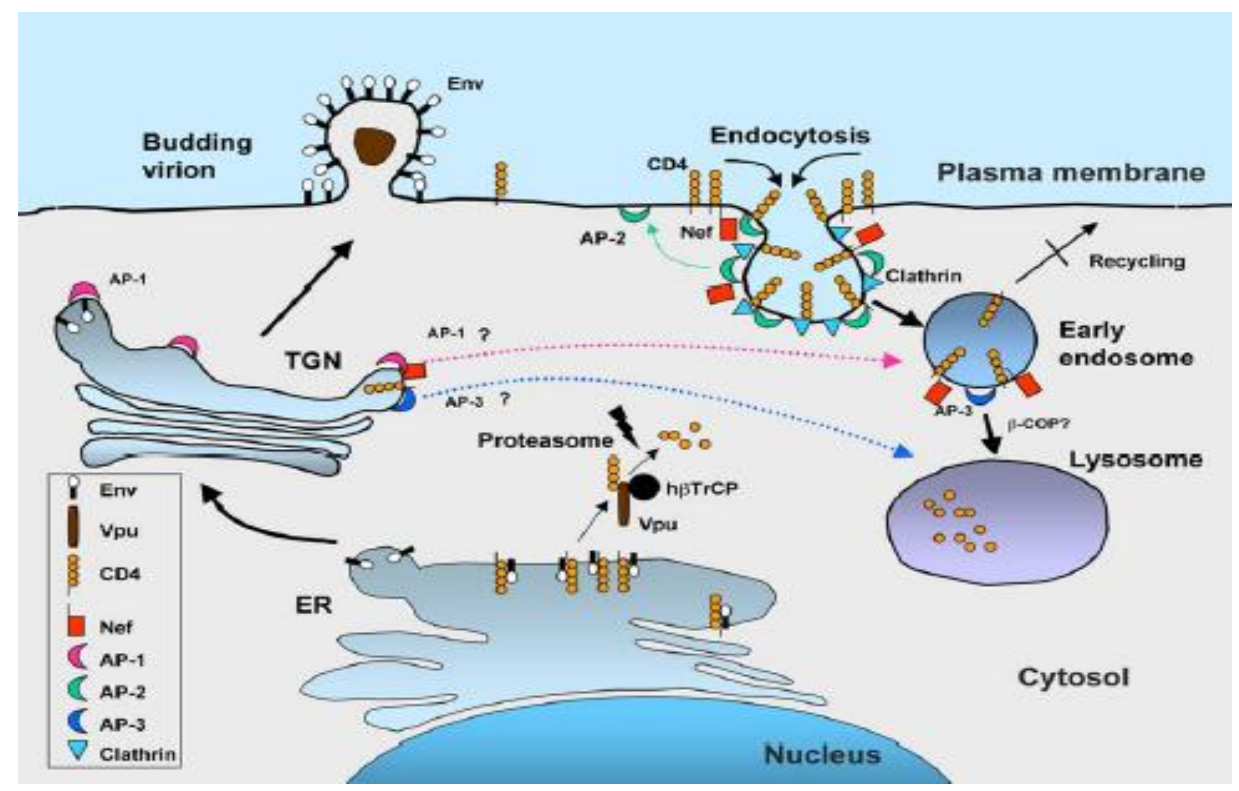

Figura 1.5. Mecanismos envolvidos na diminuição da expressão de CD4 da superfície da célula infectada pelo HIV-1. A modulação de CD4 ocorre em diferentes locais da célula infectada e envolve as proteínas virais Nef, Vpu e Env. Nef age como um conector na superfície da célula ligando o domínio citoplasmático de CD4 com o complexo proteico adaptador da clatrina AP-2, induzindo a formação de vesículas endocíticas, que posteriormente por recrutamento da proteína $\beta$-Cop, são direcionadas ao lisossoma para degradação. Já as proteínas $V p u$ e Env redirecionam as moléculas CD4 recém- sintetizadas presentes no RE, para degradação proteassômica [91].

Existem diversas hipóteses relacionadas a relevância fisiológica deste fenômeno na patogênese da AIDS, dentre as mais aceitas podem-se citar: a) evitar a ligação cruzada da molécula CD4 na superfície de células infectadas, para evitar a transdução de sinais inibitórios, os quais podem inibir a transcrição do DNA viral a partir do "Long Terminal repeat" (LTR); b) inibir a indução de apoptose e efeitos citopáticos, antes que a liberação viral aconteça [101],[102],[103]; c) impedir a superinfecção, o que poderia comprometer a produção viral [104]; d) favorecer a liberação de partículas virais [105],[106]e finalmente, evitar a diminuição da infecciosidade das partículas virais liberadas [107], [88], [91]. Porém, vale ressaltar que estas hipóteses não são excludentes podendo ocorrer concomitantemente, aumentando a eficiência do processo infeccioso.

Os primeiros trabalhos mostrando os efeitos inibitórios da expressão de CD4 na replicação viral foram de Marshall et al (1992) [108]. Posteriormente, trabalhos de Lama et al (1999), mostraram que a superexpressão do receptor viral CD4 levava a diminuição da 
infecciosidade e liberação das partículas virais e que as proteínas Nef e $V p u$ por meio da participação na diminuição da expressão do receptor da superfície viral, eram capazes de impedir os efeitos inibitórios mediados por CD4 [107]. Por outro lado, a eliminação dos efeitos inibitórios mediante o uso de partículas virais pseudotipadas, com as glicoproteínas dos vírus da estomatite vesicular (VSVg) ou com a do vírus da leucemia viral murina (MLV), mostraram claramente que este fenômeno requeria a interação da molécula CD4 e a glicoproteína de superfície viral, a gp120. Entretanto, estes estudos foram realizados em células 293T previamente transfectadas com vetores expressando a molécula CD4, o que pode levar a maior expressão da que é observada nas células infectadas naturalmente, já que estas células não expressam a proteína de transmembrana Lck, a qual se associa a CD4 na superfície viral. Com o objetivo de abordar estas questões, Cortes et al (2002) realizaram os mesmos estudos de inibição em linhagem de células Jurkat, que expressam Lck, com altos e baixos níveis de expressão de CD4. Desta forma, foi possível observar a diminuição da infecciosidade entre 75$85 \%$, ainda em células com baixos níveis de CD4, o que mostrava que pequenas quantidades de CD4 eram prejudiciais para a infecciosidade viral. Já em células expressando altos níveis de CD4 os níveis de inibição atingiram 95\% [88].

Evidências proporcionadas pelos trabalhos de Cortes et al[88] e posteriormente pelos de Argañaraz et al[91], onde foram detectados níveis de incorporação da molécula CD4 na superfície das partículas virais, sugeriram a inativação funcional da gp120 como consequência da coexpressão de ambas as proteínas na superfície do vírus.

\subsection{Estrutura de Nef e interação com as proteínas celulares}

\subsubsection{A proteína acessória Nef.}

Nef é uma proteína não enzimática miristoilada que possui entre 27 a $34 \mathrm{kDa}$, expressa exclusivamente no vírus da imunodeficiência humana (HIV - 1 e 2) e no vírus da imunodeficiência simiana (SIV). Esta proteína possui, em sua estrutura terciária, domínios específicos de ligação para diferentes proteínas celulares (Figura 1.6). 


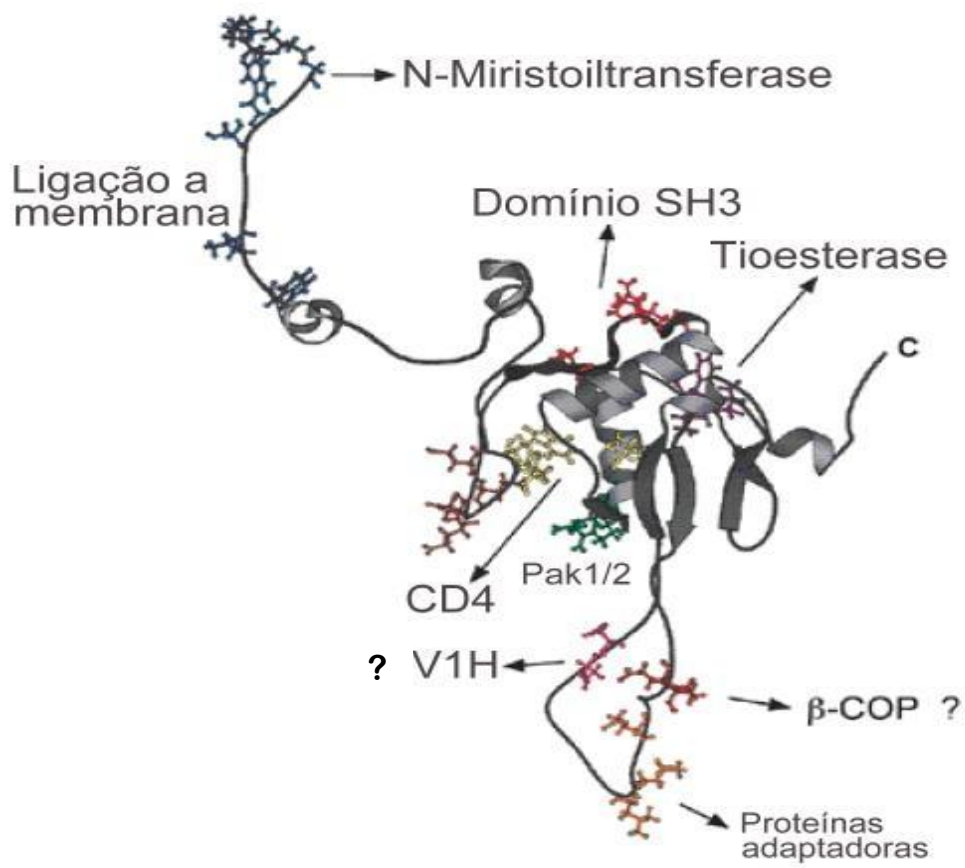

Figura 1.6. Localização de motivos funcionais na estrutura da proteína Nef do HIV-1. Representação dos motivos funcionais de Nef para interação com fatores celulares como: Tioesterase, CD4, V1H, proteínas adaptadoras de clatrina, PAK 1, PAK 2, Vav (SH3), Lck (SH3), Hck (SH3) e possivelmente $\beta$-Cop. A região Nterminal da proteína é a região de ancorameto à membrana, devido principalmente a ação da N-miristoiltrasferase [109].

A região N-terminal desta proteína, de aproximadamente 60 resíduos de aminoácidos, apresenta grande diversidade genética e flexibilidade estrutural, sendo responsável por sua ancoragem à membrana. Essa região é seguida de um domínio C-terminal (domínio central), de aproximadamente 130 aminoácidos, é bastante conservada e caracterizada pela presença de estrutura terciária estável. Entre esses dois domínios existe um sítio de clivagem para protease viral e uma região enrolada de aproximadamente 30 resíduos aminoácidos projetada para fora do domínio central. Precisamente, o sítio de clivagem pela protease do HIV 1 se encontra entre os resíduos dos aminoácidos W57 e L58. Estes aminoácidos são altamente conservados, principalmente o triptofano 57. A proteína Nef ainda possui um domínio SH3 que está envolvido na interação com proteínas de sinalização intracelular como, por exemplo, Hck, Vav e $L c k$, sendo que estas interações são fundamentais para a ativação celular mediada por Nef [110], [67] e consequentemente para a replicação viral. Nef é modificada após a tradução por fosforilação, além da miristoilação, na porção N-terminal [111], [109], [112]. Também apresenta em sua estrutura região onde se liga a cinase p21 ativada (PAK) 1 e 2, tioesterase, CD4, uma ATPase vacuolar V1H (NBP1), proteínas adaptadoras de clatrina (AP) e uma região possivelmente de interação com $\beta$-Cop [113] (Figura 1.6).

A N-miristoilação de Nef é necessária para sua associação com a membrana celular, característica esta crítica para todas as funções biológicas da proteína, tais como: modulação de 
CD4, modulação de MHC I, infecciosidade e ativação de PAK [113].

A fosforilação possivelmente está envolvida na interação entre o grupo mirístico e os seis primeiros resíduos do N-terminal de Nef. A introdução de carga negativa dentro da região de ancoragem pode bloquear a estável associação com a membrana devido a repulsão desencadeada pela carga negativa da região polar dos fosfolipídeos presentes na membrana [111].

Na figura 1.7 se encontram detalhadas as sequências de aminoácidos de quatro alelos de Nef das cepas NL43, SF2 e NA7 presentes em primatas humanos e Mac239, presentes em primatas não humanos, com os diferentes domínios de ligação as proteínas celulares.
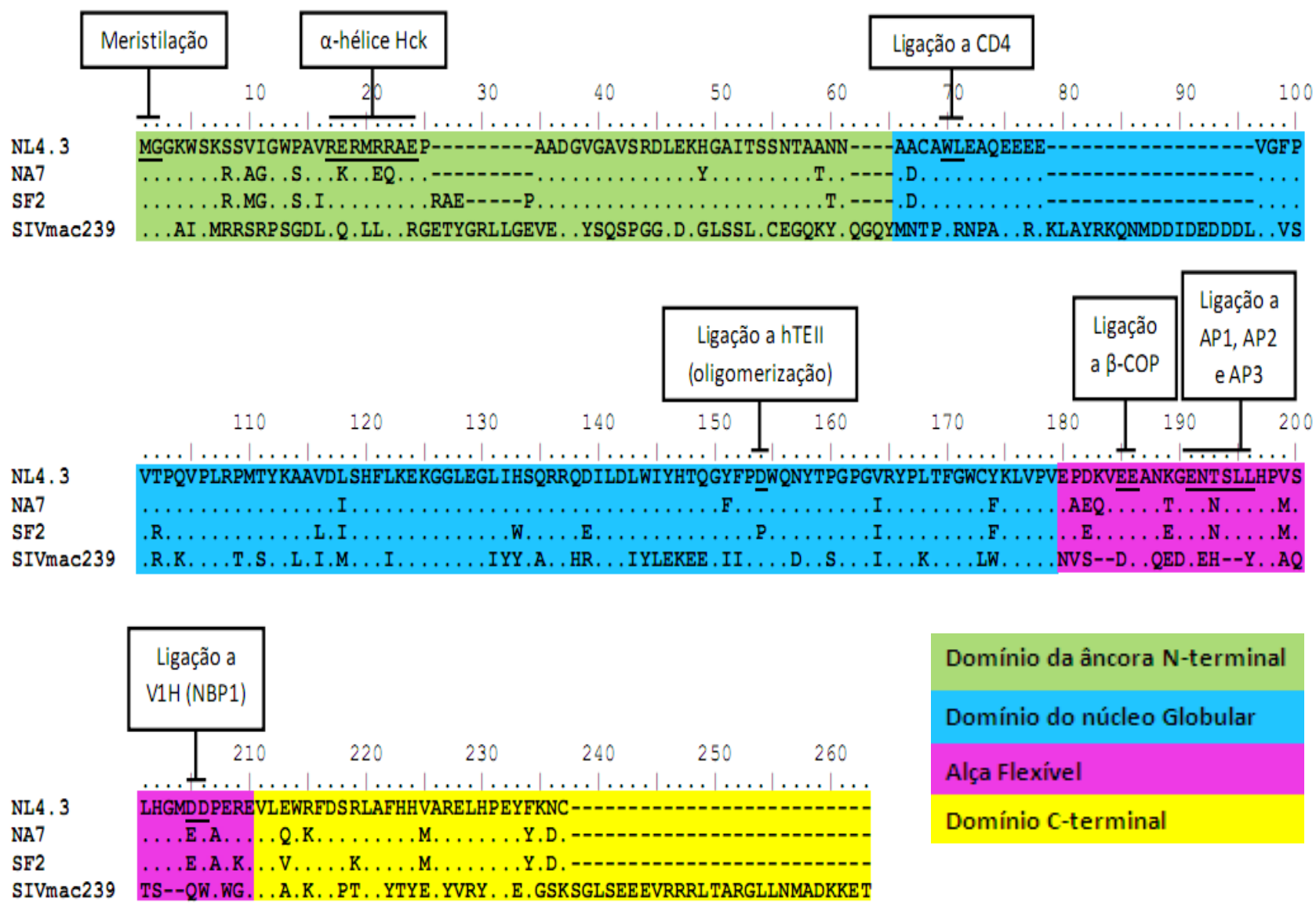

Figura 1.7. Alinhamento de diferentes alelos da proteína Nef do HIV-1 e localização de seus motivos funcionais. Representação dos motivos funcionais de Nef, em diferentes alelos, para interação com fatores celulares como: Tioesterase, CD4, V1H, proteínas adaptadoras de clatrina, Hck (SH3) e $\beta$-Cop. A região Nterminal da proteína é a região de ancoragem à membrana, devido principalmente a ação da $\mathrm{N}$-miristoiltrasferas.

Além de ser um dos fatores de virulência e patogenicidade mais importantes, as diversas funções desta proteína ainda são pouco compreendidas. A importância biológica de Nef para a replicação viral e desenvolvimento da doença foi demonstrada, "in vivo", em macacos infectados com SIV [114] e confirmada através da observação da falta de progressão à doença em pacientes infectados por vírus apresentando mutação ou deleção total de Nef [115], [116]. 
"In vitro", a falta desta proteína leva à diminuição da replicação e infecciosidade viral [117] e [93]. Mesmo sendo pouco conhecidos os efeitos de Nef "in vivo", sabe-se que "in vitro" Nef está envolvida no aumento da replicação, “release” e da infecciosidade viral em células primárias, na alteração do estado de ativação de células $\mathrm{T}$, na interferência das vias de transdução de sinais de macrófagos e na indução da modulação de moléculas de superfície celular tais como: CD4, MHC I, MHC-II, CXCR4 e CD28 [118], [119], [120], [121] e [122].

\subsubsection{Os parceiros celulares de Nef na modulação de CD4}

O mecanismo de ação de Nef tem sido estudado extensivamente e, até o momento, acredita-se que Nef atue na superfície celular como um conector da cauda citoplasmática da molécula CD4 com a proteína clatrina AP-2, pertencente ao complexo adaptador heterotetramérico [95, 123]. Essa conexão possibilita a formação de vesículas endocíticas contendo o receptor CD4 [97, 124]. Por outro lado, outras duas proteínas foram envolvidas na estabilização da ligação entre Nef e Ap2. Uma subunidade da bomba de prótons vacuolar (VATPase) ou (NBP-1) e a proteína Epsn15 um membro do sistema endocitico-interactosomo, aumentando a força de ligação de Nef a subunidade $\mu 2$ de AP-2 [125, 126] (Tabela 1.2).

Com a finalidade de evitar a reciclagem de CD4 para a superfície celular, uma segunda conexão entre CD4 e a maquinaria de tráfego celular é estabelecida por Nef, o que permite direcionar o receptor para degradação lisossômica. Foi proposto que nesse último passo Nef interagiria com Ap1, Ap3 (proteínas adaptadoras) e/ou $\beta$-COP, uma subunidade da proteína de revestimento COP-1, o principal componente das vesículas não revestidas por clatrina [95, 127].

Adicionalmente, uma tioesterase humana $h T E-I I$, que hidrolisa ligações tioéster de acilCoA in vitro, também foi proposta estar envolvida na modulação de CD4 por Nef com o alelo NL43 [128, 129]. A habilidade de algumas mutantes de Nef em modular negativamente CD4 foi correlacionada com a capacidade das mesmas de se ligar a hTE-II/AcoT8 [128, 130], entretanto, sua relevância ainda não é bem esclarecida. Finalmente, a proteína dynamin2 (Dyn2), outra proteína também reguladora do tráfego vesicular, mostrou ligar-se a Nef, aumentando a infecciosidade e potencializando a modulação de CD4 [131] (Tabela 1.2).

\begin{tabular}{|c|c|c|c|}
\hline Proteína Celular (domínio) & Métodos de Detecção & Domínio de Nef & Ref \\
\hline CD4 (cauda citoplasmático) & $\begin{array}{c}\text { NMR, Yeast 2-hybrid,Co- } \\
\text { IP, Fluorescence } \\
\text { spectroscopy, BRET }\end{array}$ & $\mathrm{WL}_{58}$ & 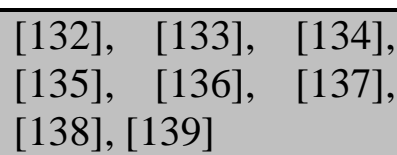 \\
\hline AP-1 (hemicomplex) & $\begin{array}{c}\text { Yeast 2-hybrid, Yeast 3- } \\
\text { hybrid, GST pulldown, Co- } \\
\text { IP }\end{array}$ & EXXXLL $_{165}$ & $\begin{array}{ll}{[125],} & {[140],} \\
{[141],[142],} & {[109],} \\
{[143],[144],} & {[145],}\end{array}$ \\
\hline
\end{tabular}




\begin{tabular}{|c|c|c|c|}
\hline AP-2 (hemicomplex) & GST pulldown, Co-IP & EXXXLL $_{165}$ & [148], [109], [143] \\
\hline AP-3 (hemicomplex) & $\begin{array}{c}\text { Yeast 2-hybrid, Yeast 3- } \\
\text { hybrid,GST pulldown, Co- } \\
\text { IP }\end{array}$ & EXXXLL $_{165}$ & $\begin{array}{ll}{[140],[141],} & {[143],} \\
{[144],} & {[145],} \\
{[146],[147]} & \end{array}$ \\
\hline$\beta$-COP (C-terminal) & $\begin{array}{c}\text { Yeast 2-hybrid, GST } \\
\text { pulldown, Co-IP }\end{array}$ & $\mathrm{EE}_{155}$ & $\begin{array}{l}{[149], \quad[150], \quad[151],} \\
{[95]}\end{array}$ \\
\hline V1H (aa 133-363 e 402-283) & GST pulldown, Co-IP & $\begin{array}{c}\text { EXXXLL }_{165} \mathrm{e} \\
\mathrm{DD}_{175}\end{array}$ & [109] \\
\hline AcoT8/hTEII (C-terminal) & $\begin{array}{c}\text { Yeast 2-hybrid, GST } \\
\text { pulldown, Co-IP }\end{array}$ & $\mathrm{D}_{123}$ & [128] \\
\hline Hck ( $\alpha$-hélice) & $\begin{array}{l}\text { Yeast 2-hybrid, GST } \\
\text { pulldown, Co-IP }\end{array}$ & RERMRRAE $_{24}$ & $\begin{array}{l}{[67,110,137,152-} \\
154]\end{array}$ \\
\hline
\end{tabular}

Tabela 1.2. Descrição das interações entre Nef e proteínas celulares. São descritas as proteínas celulares parceiras da proteína Nef do HIV-1 e as sequências de aminoácidos correspondentes aos domínios de ligação presentes em Nef.

Recentemente, foi descrito que a ubiquitinização de $N e f$, fenômeno conservado em todas as linhagens de HIV e SIV, seria crítica na degradação de CD4 [155].

Até o momento nenhuma atividade catalítica foi atribuída à proteína Nef, corroborando a hipótese de que as funções desta proteína viral são mediadas por interações específicas com seus parceiros celulares, interações estas que foram comumente caracterizadas em ensaios de "sistema duplo híbrido" (two-hybrid-system), realizados em leveduras, e posteriormente validados com experimentos de imunoprecipitação e colocalização em células de mamífero. Devido à dificuldade em neutralizar a expressão endógena destes genes, a relevância fisiológica destas interações não foi confirmada. Experimentos realizados para avaliar o papel destes parceiros celulares de $\mathrm{Nef}$ usualmente foram realizados como auxílio de versões negativas das diferentes proteínas celulares [156]. Evidências adicionais têm sido obtidas correlacionando os efeitos das mutantes dos parceiros celulares com a habilidade de $N e f$ de modular a expressão de CD4. Entretanto, nenhum destes estudos tem apresentado evidências conclusivas com relação ao envolvimento destas proteínas celulares na diminuição de CD4 mediada por Nef, uma vez que as estratégias experimentais se basearam somente na superexpressão de proteínas mutantes, o que pode levar a resultados confusos. Por outro lado, nos trabalhos descritos anteriormente o papel das diferentes proteínas celulares não foram avaliados na presença dos diferentes alelos de Nef, fator este de extrema importância, levando em consideração a grande diversidade de sequências apresentada pelas diferentes cepas do HIV, o que sugere a utilização de mecanismos alternativos na degradação do receptor CD4. No entanto, mesmo levando em considerações a falta de exploração de resultados em outras cepas, há ainda um outro agravante que é grande contraversão nos resultados publicados no qual o nível de interação entre $N e f$ e fatores celulares 
não foram esclarecidos e tão pouco, se confirmada a interação, qual seria a relevância fisiológica destas interações na indução da modulação do receptor CD4 pela proteína viral Nef $[96,97,123,125,151,157]$.

\subsubsection{A molécula CD4}

A molécula de CD4 (“cluster of differentiation 4") é uma glicoproteína integral com 55 kDa encontrada na superfície de linfócitos $\mathrm{T}$ e macrófagos [158, 159]. Esta proteína está envolvida na adesão celular [160], sinalização molecular durante a ativação celular [161] e também serve como receptor para o vírus da imunodeficiência humana (HIV) [162]. A molécula de CD4 possui 5 resíduos de cisteína espalhados pelos domínios citoplasmáticos e transmembrânicos. Dois destes resíduos, C420 e C422, fazem parte dos oito resíduos de aminoácidos presentes na parte citoplasmática da molécula envolvida na ligação de CD4 com a proteína Nef do HIV-1 [163, 164].

Nef liga-se à CD4 e utiliza da maquinaria celular de reciclagem endógena do receptor para reduzir a expressão deste na célula [165].

\subsubsection{As proteínas adaptadoras de complexos (APS)}

Estas proteínas são responsáveis pela formação de complexos vesiculares que mediam o tráfego intracelular de proteínas [166]. As APs são seletivamente recrutadas pelas proteínas por ligações com motivos lineares contendo os aminoácidos tirosina ou dileucina canônicos em domínios citoplasmáticos.

A especificidade do recrutamento de AP baseia-se, em parte, na distribuição subcelular do complexo AP. Por exemplo, AP-1 se localiza no trans-Golgi (TNG), AP-2 na membrana plasmática e por sua vez AP-3 em endossomos, sendo diretamente mediados em cargo da seleção local [167], [168], [169], [170].

Há algumas sobreposições na atividade das APs, portanto, proteínas acessórias são recrutadas dependendo de sua especificidade. Por exemplo, anfifisina, endofilina, epsina, AP180, e Hip1/Hip1R são associadas com AP-2 [171]. Epsina R[172], entoprontina [173], e proteínas possivelmente associadas ao Golgi [167], participam com AP-1. Estes complexos multiproteicos formados por AP-1 e AP-2 e suas respectivas proteínas acessórias permitem a formação de moléculas com revestimentos de clatrina com facilidade [174]. Em contraste, AP3 mostrou-se capaz de mediar a formação tanto de moléculas revestidas por clatrina como moléculas vesiculares [175].

Finalmente, a localização e composição lipídica, também estão diretamente relacionadas ao recrutamento AP, por exemplo; as kinases lipídicas têm sido utilizadas como transportes 
vesiculares em várias localizações intracelulares [174].

\subsubsection{Proteína V1H}

A subunidade $\mathrm{H}(\mathrm{V} 1 \mathrm{H})$ da ATPase vacuolar de membrana é uma enzima que media a acidificação de organelas intracelulares eucarióticas. Essa acidificação faz-se necessária em vários processos intracelulares, tais como: seleção de proteínas, ativação zimogênica, reciclagem de receptores mediados por endocitose e vesícula sináptica para geração de gradiente de prótons. Em células eucariontes o gradiente de prótons é utilizado para direcionar a formação de ATP e o transporte de metabólicos através da membrana mitocondrial interna [176], [177].

A proteína $\mathrm{V} 1 \mathrm{H}$ é composta por um domínio $\mathrm{V} 1$ citosólico e um domínio V0 transmembrânico. O domínio V1 consiste em subunidades; A, B, G, C, D, E, F e H, este domínio possui o sítio de ATP catalítico. A subunidade H é a responsável pela regulação do domínio V1, que é necessário para a catálise de ATP[85],[178].

V1H se liga no sítio da cadeia " $\mu$ " de AP-2, e está descrito interagir na ligação com CD4 pelo complexo AP-2 clatrina [126], [125],[179].

\subsubsection{Proteína COP-1}

A proteína COP-1 é um “coatomer”(proteína de revestimento) que desempenha um papel relativamente definido na segmentação retrógrada das proteínas do retículo endoplasmático (RE), assim como selecionar vesículas transportadoras no Golgi [180]. Outra interessante, mas ainda não muito elucidada atividade de COP-1 é na participação na movimentação dos endossomos. COP-1 vem sido mostrado como capaz de se ligar às membranas de endossomos, de maneira pH-dependente [181], [135], e se envolver na reciclagem endocítica [182], na biogênese do comportamento multivesicular [183], formação de fagosomos [184], [185], e no transporte retrógrado da membrana plasmática para o RE [186],[187].

A interação entre Nef e $\beta$-COP, um componente de COP-1, foi identificada por Benichou, S. et al em 1994 [149], e há evidências que esta interação está diretamente correlacionada com a acidificação de endossomos tardios responsáveis pela modulação de CD4 Nef-induzida [188].

Devido ao grande número de parceiros Nef teria capacidade de controlar o transporte intracelular de várias proteínas em diferentes níveis. De fato, foram descritas anormalidades na morfologia endossomal de vários grupos de proteínas induzidos por Nef [127], [151], [189], e a expressão de Nef aumentaria a quantidade de endossomos, lisossomos e corpos multivesiculares [189], [190], [91], [151], [191], [121], [118],[192]. 


\subsubsection{Proteína hTEII/AcoT8}

A tioesterase humana II (hTE/AcoT8) também foi envolvida no processo de endocitoses de CD4 mediado por Nef [128]. Entretanto, a participação desta proteína no mecanismo de modulação de CD4 foi questionada desde que alguns alelos de Nef, como os presentes nas cepas SF2 do HIV-1 e mac239 no SIV, não interagem com esta proteína celular, mas continuam diminuindo eficientemente a expressão da molécula CD4 [129]. O resíduo D123 de Nef foi descrito como crítico na interação com AcoT8, assim como na dimerização da proteína viral na modulação de CD4 e do complexo de histocompatibilidade do tipo I (MHC I) [128].

Ornelas (2007), mostrou que o bloqueio desta proteína, aumentaria os níveis de expressão de CD4 independentemente da presença da proteína Nef, o que confirmaria a importância de AcoT8 para a reciclagem endógena do receptor de superfície CD4 [193].

\subsubsection{Proteína Eps 15}

Esta proteína é um componente da via Receptores de Fatores de Crescimento Epidermal (EGFR). E está presente em vesículas formadas por clatrina, envolvidas na endocitose de receptores de superfície. A Eps15 é um fator importante na formação, envaginação e fusão de complexos endocíticos de clatrina mediado pela proteína AP2 [194].

Não há relatos da participação desta proteína na modulação de CD4 mediada por Nef, entretanto, já está bastante elucidado seu papel na reciclagem de receptores de superfície [195].

\subsubsection{Proteína Dyn 2}

Proteína da família de GTPases, possui no N-terminal um domínio GTP, responsáveis por se ligarem e hidrolisarem a molécula de guanosina trifosfato. A Dinamyna 2 (Dyn2), é um importante fator no processo de endocitose e mobilidade intracelular [196].

Foi descrita, por exercer um importante papel no aumento na infectuosidade viral Nef dependente, embora não interaja diretamente com a proteína viral [197], [198].

\subsection{Técnicas para a caracterização de proteínas}

\subsubsection{A técnica FACS/FRET}

Uma das poucas técnicas, não evasivas, para o estudo de interação entre proteínas seria a técnica de Fösters resonance energy transfer (FRET) [199], [200]. A técnica FRET é baseada sobre a transferência de energia de um fluoróforo doador excitado para um fluoróforo aceptor próximo, resultando no aumento de fluorescência emitida pelo aceptor [201]. Entretanto, esta técnica é baseada por microscopia de fluorescência, o que além de demorado, essencialmente 
impede a análise de interação entre proteína em ensaios com grande número de células, highthroughput-screening (HTS) [199], [200].

A técnica de Fluorescence activated cell sorting (FACS), além de não evasiva, é uma técnica sensível e quantitativa, que permite medir um grande numero de células em um período de tempo razoável [202].

Em 2010, Banning, et al., mostrou que estas duas técnicas podem ser utilizadas em conjunto no estudo de interação entre proteínas. Estes estabeleceram um versátil ensaio de FACS, baseado em FRET, usando como padrão positivo para FRET o par CFP/YFP [203]. Ensaio que puderam demonstrar a aplicabilidade da técnica em ensaios de HTS, pela seleção de células FRET positivas [204].

\subsubsection{A técnica de RNA de interferência}

Um dos grandes avanços nas últimas décadas na biologia molecular foi a descoberta de que as moléculas de RNA podem regular a expressão de genes [205]. Por muitos anos as moléculas de RNA eram conhecidas apenas por participar em processos clássicos como transcrição, processamento e tradução. Porém estes conceitos começaram a ser mudados quando em 1998 cientistas descreveram um novo mecanismo de inibição da expressão gênica induzido pela presença de RNA de dupla fita (dsRNA), conhecido como silenciamento da expressão gênica por RNA de interferência (RNAi) [205]. Este fenômeno foi inicialmente caracterizado como um mecanismo de defesa celular contra infecção viral e mobilização de transposons que funcionavam através da inibição traducional por dsRNA [206]. Desde então, este mecanismo também foi descrito em plantas, protozoários, nematóides e insetos. Mostrando sua conservação através da evolução das espécies [207].

O mecanismo de RNAi se tornou poderosa ferramenta para estudo das funções gênicas e bloqueio de infecções pela introdução de dsRNA homólogas ao RNAm alvo [208], [209], [210], [211].

O uso de RNAi também tem sido utilizado no combate a doenças como câncer, diabetes e outras doenças que envolvem patógenos como vírus, bactérias, fungos e protozoários [212], [213], [214], [215], devido o RNAi ter o poder de bloquear a expressão de genes possivelmente envolvidos nos processos patogênicos.

Apesar de que os genes virais possam servir como alvos para terapia gênica utilizando shRNA(short hairpin RNA), genes do hospedeiro também podem representar bons alvos, já que possuem maior estabilidade em seus processos de transcrição e tradução. Desta forma, a modulação do receptor CD4, que é um importante evento durante a infecção pelo HIV-1, pode 
ser um bom campo de estudo para a utilização da abordagem por RNA silenciador (shRNA) como ferramentas para melhor compreensão deste processo fisiológico. 
Capítulo 2. Relevância da Pesquisa e Objetivos 


\subsection{Relevância da Pesquisa}

Aproximadamente 20 anos após o desenvolvimento e implementação de terapia antiretroviral (TAR), a pesquisa em HIV/Aids atingiu uma encruzilhada. O surgimento de variantes virais resistentes às drogas antiretrovirais [216], o estabelecimento dos reservatórios virais latentes e resistentes ao TAR e a resposta imune do hospedeiro [217-219], assim como os efeitos citotóxicos causados pelo tratamento, fez com que a descoberta de novas abordagens terapêuticas seja uma prioridade na pesquisa relacionada HIV/Aids.

Diversos achados evidenciaram a importância da diminuição da expressão do receptor CD4 na patogênese da doença in vivo. As evidências mais diretas da participação deste fenômeno na progressão da doença foram obtidas de grupos de pacientes não-progressores, onde foi possível verificar uma correlação entre a presença de um pool de vírus deficientes nesta função, a falta de progressão à doença e a modulação do receptor CD4 mediada por Nef [220, 221]. Por outro lado, em estudos realizados pelo nosso grupo foi possível demonstrar que a maior infectividade observada em vírus isolados nos estágios finais da infecção se devia, pelo menos em parte, a maior eficiência destas variantes virais em diminuir da expressão de CD4 [91].

Estes estudos sugerem fortemente que a capacidade de diminuir a expressão do receptor viral CD4 pode contribuir para o aumento da carga viral observada em pacientes portadores de AIDS, o que nos levou a hipotetizar que a inibição desta função viral poderia retardar a progressão da doença e consequentemente melhorar o quadro clínico de pacientes HIV positivos.

Para nosso conhecimento, a modulação do receptor CD4 induzida pelo vírus HIV ainda não foi considerada como um alvo terapêutico. Entretanto, nosso grupo iniciou esforços para avaliar o impacto que esta nova abordagem terapêutica poderia ter na replicação viral. Dessa forma estudos preliminares mostraram que a expressão na membrana celular de moléculas CD4 insensíveis à modulação induzida por Nef reduz dramaticamente a infectividade e a replicação viral [222].

Baseando-nos nestes dados encorajadores, hipotetizamos que o bloqueio do mecanismo responsável pela diminuição da expressão de CD4, através da identificação e inibição dos parceiros celulares de Nef envolvidos nesta função poderia constituir uma nova e efetiva abordagem terapêutica. 


\subsection{Objetivos}

\subsubsection{Objetivo geral:}

Determinar a relevância fisiológica de putativos parceiros celulares da proteína viral Nef na modulação do receptor CD4.

\subsubsection{Objetivos específicos}

1. Desenvolver vetores lentivirais que expressem shRNA contra os diferentes parceiros celulares de Nef.

2. Avaliar a eficiência dos vetores lentivirais na inibição da expressão das proteínas celulares.

3. Avaliar a interação e co-localização entre as proteínas celulares e os diferentes alelos de Nef de primatas humanos e não humanos e o receptor CD4.

4. Analisar o efeito da redução dos níveis de expressão das proteínas celulares na modulação de CD4 mediada por diferentes alelos de Nef de primatas humanos e não humanos em linha de células T.

5. Determinar a relevância fisiológica da inibição dos parceiros celulares de Nef na modulação do receptor viral CD4 em linfócitos T de sangue periférico infectados pelo HIV-1. 
3. Materiais e Métodos 


\subsection{Linhagens celulares}

Para a produção de partículas virais foi utilizada a linhagem celular aderente de fibroblastos de rim humano denominada $293 \mathrm{~T}$ foi cultivada a $37^{\circ} \mathrm{C}$ em atmosfera de $5 \%$ de $\mathrm{CO}_{2}$ em meio de cultura Dulbecco Modified Eagle Medium (DMEM) suplementado com 10\% de Soro Bovino Fetal inativado (SFB). Os experimentos de avaliação da relevância fisiológica dos parceiros celulares de Nef na degradação de CD4 foram realizados na linha celular de linfócitos T-CD4 ${ }^{+}$, SupT-1. Esta linhagem celular foi cultivada a $37^{\circ} \mathrm{C}$ em atmosfera de $5 \%$ de $\mathrm{CO}_{2}$ em meio de cultura Roswell Park Memorial Institute (RPMI 1640) suplementado com 10\% de Soro Bovino Fetal inativado (SFB). Finalmente, também foram utilizados para tal fim linfócitos $\mathrm{T}-\mathrm{CD}^{+}$isolados a partir de células mononucleadas do sangue periférico "peripherical blood mononuclear cell" - PBMC os que foram cultivados em meio RPMI 1640 suplementado com 10\% de Soro AB Humano (SABH) e 50 U de interleucina-2 (IL-2) / ml. As células de PBMC foram ativadas com $5 \mu \mathrm{g} / \mathrm{ml}$ phytohemagglutinin (PHA) por 2 dias antes de serem infectadas ou transduzidas. Todo meio de cultura usado foi suplementado com $100 \mathrm{U}$ de penicilina/ml, $100 \mu \mathrm{g}$ de streptomicina/ml, $1 \mathrm{mM}$ de piruvato de sódio e $2 \mathrm{mM}$ de glutamina.

\subsection{Construção de vetores de expressão}

\subsubsection{Desenvolvimento de vetores de fusão codificando proteínas celulares e alelos da} proteína Nef

No primeiro momento foram construídos vetores de fusão codificando seis proteínas celulares, possíveis parceiras da proteína Nef na modulação de CD4, (hTEII, Ap1 $\sigma$, Ap2 $\sigma$, Ap2 $\mu, \mathrm{V} 1 \mathrm{H}, \beta-\mathrm{COP}$ ), três alelos da proteína Nef presentes em primatas humanos (NA-7, Sf2, NL4.3), um presente em primatas não humanos (Smm. Mac239) e o receptor celular CD4.

\subsubsection{Reação de Polimerização em Cadeia (PCR)}

As sequências dos genes correspondentes às diferentes proteínas foram amplificadas por PCR utilizando-se oligonucleotídeos específicos para cada proteína contendo os sítios para as enzimas de restrição Nhe I e Age I, e a sequência necessária para posterior clonagem e fusão destes genes nos vetores de expressão pECFP e pEYFP (proteína de fluorescência “cyan” e proteína de fluorescência “yellow”'respectivamente).

Os oligonucleotideos foram desenhados a partir da sequência de nucleotídeos correspondentes aos cDNA de cada uma das proteínas, obtidas no site do National Center for Biotechnology Information (ncbi) www.ncbi.nlm.nih.gov/RefSeq/HIVInteractions/nef.html. (Tabela 3.1). 


\begin{tabular}{|c|c|c|}
\hline Nome & Sequências & $\mathbf{N}^{\mathbf{0}}$ de bp \\
\hline 5'hTEII-Nhe I & TGCGGCTAGCATGtcgtccccgcagg & $1188 \mathrm{bp}$ \\
\hline 3'hTEII-Age I & TCGACCGGTGCACCTGCTCCcaggtctcagagag & $1188 \mathrm{bp}$ \\
\hline 5'CD4-Nhe I & TGCGGCTAGCATGaaccggggagtccc & $3134 \mathrm{bp}$ \\
\hline 3'CD4-Age I & TCGACCGGTGCACCTGCTCCaaagaaagtgg & $3134 \mathrm{bp}$ \\
\hline 5'VH1-Nhe I & TGCGGCTAGCATGaccaaaatggatatc & $1449 \mathrm{bp}$ \\
\hline 3'VH1-Age I & TCGACCGGTGCACCTGCTCCgcttcgggcggcagcgg & $1449 \mathrm{bp}$ \\
\hline 3'AP1 $\gamma$-Age I & TGCGGCTAGCATGcagtttatgttgctttttag & $2468 b p$ \\
\hline 5'AP1 $\gamma$-Nhe I & TCGACCGGTGCACCTGCTCCtgtcagtccaatttcttc & $2468 \mathrm{bp}$ \\
\hline 5 'AP2 $\sigma-$ Nhe I & TGCGGCTAGCATGatccgetttatcctcatccagaaccgggc & 428bp \\
\hline 3'AP2 $\sigma$-Age I & TCGACCGGTGCACCTGCTCCctccagggactgtagcatcagc & $428 \mathrm{bp}$ \\
\hline $5^{\prime} \mathrm{AP} 2 \mu-$ Nhe I & TGCGGCTAGCATGattggaggcttattcatc & $1301 b p$ \\
\hline 3'AP2 $2 \mu$-Age I & TCGACCGGTGCACCTGCTCCgcagcgagtttcataaatgccactgc & $1301 b p$ \\
\hline 5'AP3 $\mu$-Nhe I & TGCGGCTAGCATGatccatagtcttttcttgatca & $1256 \mathrm{bp}$ \\
\hline 3'AP3 $\mu$-Age I & TCGACCGGTGCACCTGCTCCggttcgaacttggaacttcccagctttgg & $1256 \mathrm{bp}$ \\
\hline $5^{\prime} \beta-\mathrm{COP} 1-\mathrm{Nhe} \mathrm{I}$ & TGCGGCTAGCATGacggcggctgagaacgtatg & $2861 \mathrm{bp}$ \\
\hline 3' $\beta$-COP1-Age I & TCGACCGGTGCACCTGCTCCtatactagttttettetg & $2861 \mathrm{bp}$ \\
\hline Nef. NL4.3-Nhe I & TGCGGCTAGCATGggtggcaagtggtc & $618 b p$ \\
\hline Nef. NL4.3-Age I & TCGACCGGTGCACCTGCTCCacttcaagaactgc & $618 b p$ \\
\hline Nef. NA-7 -Nhe I & TGCGGCTAGCATG ggtggcaagtggtc & $618 b p$ \\
\hline Nef. NA-7 -Age I & TCGACCGGTGCACCTGCTCCacttcaagaactgc & $618 b p$ \\
\hline Nef. SF2-Nhe I & TGCGGCTAGCATGggtggcaagtggtc & $618 b p$ \\
\hline
\end{tabular}




\begin{tabular}{|llc|}
\hline Nef. SF2-Age I & TCGACCGGTGCACCTGCTCCacttcaagaactgc & $618 \mathrm{bp}$ \\
Nef. Mac.239-Nhe I & TGCGGCTAGCATGggtggcaagtggtc & $618 \mathrm{bp}$ \\
Nef. Mac.239-Age I & TCGACCGGTGCACCTGCTCCacttcaagaactgc & $618 \mathrm{bp}$ \\
\hline
\end{tabular}

Tabela 3.1. Sequências de primers para amplificação de proteínas celulares e alelos de Nef. As sequências de primers foward e reverse para a amplificação dos cDNAs correspondentes as diferentes proteínas celulares, assim como para os alelos da proteína Nef do HIV-1 são descritos em caixa baixa. As sequências complementares às sequencias dos respectivos sítios de fusão entre proteínas de expressão e as proteínas celulares, juntamente com sítios específicos para clivagem encontram-se descritos em caixa alta.

Para amplificação dos diferentes cDNAs juntamente com a sequência necessária para a fusão dos mesmos nos vetores de expressão, foram utilizados dois diferentes programas de PCR dependendo do tamanho dos fragmentos a serem amplificados. O primeiro programa de PCR (programa 1) foi elaborado para genes de tamanho maior a 1.400 pares de bases (CD4, VH1, AP1 $\gamma$ e $\beta$-COP1). Já o segundo programa de PCR (programa 2) foi utilizado para amplificação de genes com menos de 1.400 pares de bases (AcoT8, AP2 $\sigma$, AP2 $\mu$ e os diferentes alelos da proteína Nef do HIV-1; Nef NL4.3; Nef NA7; Nef SF2 e o alelo do SIV, Nef Mac.239)

Em ambas as reações de amplificação das proteínas celulares, foi utilizado como "template" o banco de cDNA extraído de células HeLa (células de adenocarcinoma cervical humano). Já no caso da amplificação dos alelos de Nef, foi utilizado como "template" plasmídeos (cedidos gentilmente pelo Dr. Michael Schindler do Heinrich Pette Institut Hamburgo, Alemanha) carregando a versão selvagem da proteína $N e f$ de diferentes cepas do HIV-1 (SF2, NA7, Mac239 e NL4.3). Em todas as reações foi usada a enzima polimerase utilizada foi a "Phusion High-Fidelity DNA Polymarese", uma Taq polimerase de alta fidelidade e processamento (índice de erro 50 vezes menor que a Taq DNA Polymerase e 6 vezes menor que a "Pyrococcus furiosus" DNA Polymerase e com atividade exonuclease de "proofereading" 3'- 5')

Condições do primeiro programa de PCR: 1X "Phusion High-Fidelity Buffer"; 10 mM de cada deoxinucleotídeo trifosfato; $1 \mu \mathrm{l}$ de dimetilsulfóxido (DMSO); 0,75 $\mu \mathrm{M}$ de cada "primer"; uma unidade $(0,5 \mu \mathrm{l})$ de "Phusion ${ }^{\circledR}$ High-Fidelity DNA "Polymarese" ("New England Bio Labs”) e, por fim, quantidade de água mili Q suficiente para um volume final de $50 \mu 1$. 
$>\quad 1^{\circ}$ Programa de PCR.

$96^{\circ} \mathrm{C}-5 \mathrm{~min}$

$96^{\circ} \mathrm{C}-60 \mathrm{seg}$

$52^{\circ} \mathrm{C}-60 \mathrm{seg}$

$\left.72^{\circ} \mathrm{C}-8 \mathrm{~min}\right\} 37$ ciclos

$72^{\circ} \mathrm{C}-10 \mathrm{~min}$

$4^{\circ} \mathrm{C}-\infty$

$\left.\begin{array}{l}\text { CD4 - Nhe I : 5' - TGCGGCTAGCATGtcgtccegcagg - 3' } \\ \text { CD4 - Age I : 5' - TCGACCGGTGCACCTGCTCCcaggtctcagaGag - 3, }\end{array}\right\} 3134 \mathrm{pb}$

$\left.\begin{array}{l}\text { VH1 - Nhe I : 5' - TGCGGCTAGCATGaccaaatggatatc - 3, } \\ \text { VH1 - Age I : 5' - TCGACCGGTGCACCTGCTCCgcttcgggeggcagcgg - 3, }\end{array}\right\} 1449 \mathrm{pb}$

AP1 $\gamma$ - Nhe I : 5' - TGCGGCTAGCATGcagtttatgttgetttttag - 3' AP1 $\gamma$ - Age I : 5' - TCGACCGGTGCACCTGCTCCtgtcagtccaatttcttc - 3, $\} 2468 \mathrm{pb}$

B-COP1 - Nhe I : 5'-TGCGGCTAGCATGacggeggetgagaacgtatg - 3,

及-COP1 - Age I : 5'-TCGACCGGTGCACCTGCTCCtatactagttttettctg - 3, $\} 2861 \mathrm{pb}$

Condições do segundo programa de PCR: 1X Phusion High-Fidelity Buffer; $10 \mathrm{mM}$ de cada deoxinucleotídeo trifosfato; $0,5 \mu \mathrm{M}$ de cada primer; uma unidade $(0,5 \mu \mathrm{l})$ de Phusion ${ }^{\circledR}$ High-Fidelity DNA Polymarese (New England Bio Labs) e, por fim, quantidade de água mili Q suficiente para um volume final de $50 \mu l$.

$>\quad 2^{\circ}$ Programa de PCR.

$96^{\circ} \mathrm{C}-5 \mathrm{~min}$

$96^{\circ} \mathrm{C}-60 \mathrm{seg}$

$52^{\circ} \mathrm{C}-60 \mathrm{seg}$

$\left.72^{\circ} \mathrm{C}-4 \min \right\} 35$ ciclos

$72^{\circ} \mathrm{C}-8 \mathrm{~min}$

$4^{\circ} \mathrm{C}-\infty$ 
AcoT8 - Nhe I : 5' - TGCGGCTAGCATGtcgtccecgcagg - 3,

AcoT8 - Age I : 5' - TCGACCGGTGCACCTGCTCCcaggtctcagaGag - 3,

AP2 $\sigma$ - Nhe I : 5'-TGCGGCTAGCATGatcegctttatcetcatccagaaccgggc - 3' AP2б-AgeI: 5'-TCGACCGGTGCACCTGCTCCetccagggactgtagcatcagc-3'

$\mathrm{AP} 2 \mu \quad-\quad$ Nhe I : 5, - TGCGGCTAGCATGattggaggettattcatc - 3,

AP2 $\mu$-AgeI: 5'-TCGACCGGTGCACCTGCTCCgcagcgagtttcataatgecactgc-3'

Nef NL4.3 - Nhe I : 5' - TGCGGCTAGCATGggtggcaagtggtc - 3'

Nef NL4.3 - Age I : 5' - TCGACCGGTGCACCTGCTCCacttcaagaactge - 3,

Nef NA-7 - Nhe I : 5'- TGCGGCTAGCATGggtggcaagtggtc - 3'

Nef NA-7 - AgeI : 5'- TCGACCGGTGCACCTGCTCCacttcaagaactgc -3'

Nef SF2 - Nhe I : 5' - TGCGGCTAGCATGggtggcaagtggtc - 3'

Nef SF2- AgeI : 5'- TCGACCGGTGCACCTGCTCCacttcaagaactgc -3'

Nef Mac239 - Nhe I : 5' - TGCGGCTAGCATGggtggcaagtggtc - 3'

Nef Mac239 - Age I : 5'- TCGACCGGTGCACCTGCTCCacttcaagaactgc -3'

\subsubsection{Estratégia de clonagem}

Os produtos de PCR contendo os sítios de restrição para as enzimas Nhe I e Age I foram digeridos com as mesmas enzimas, purificados do gel de agarose por meio de coluna de cromatografia para extração de DNA em gel de agarose (Promega) e clonados nos vetores de expressão pECFP e pEYFP (Figura 3.1).

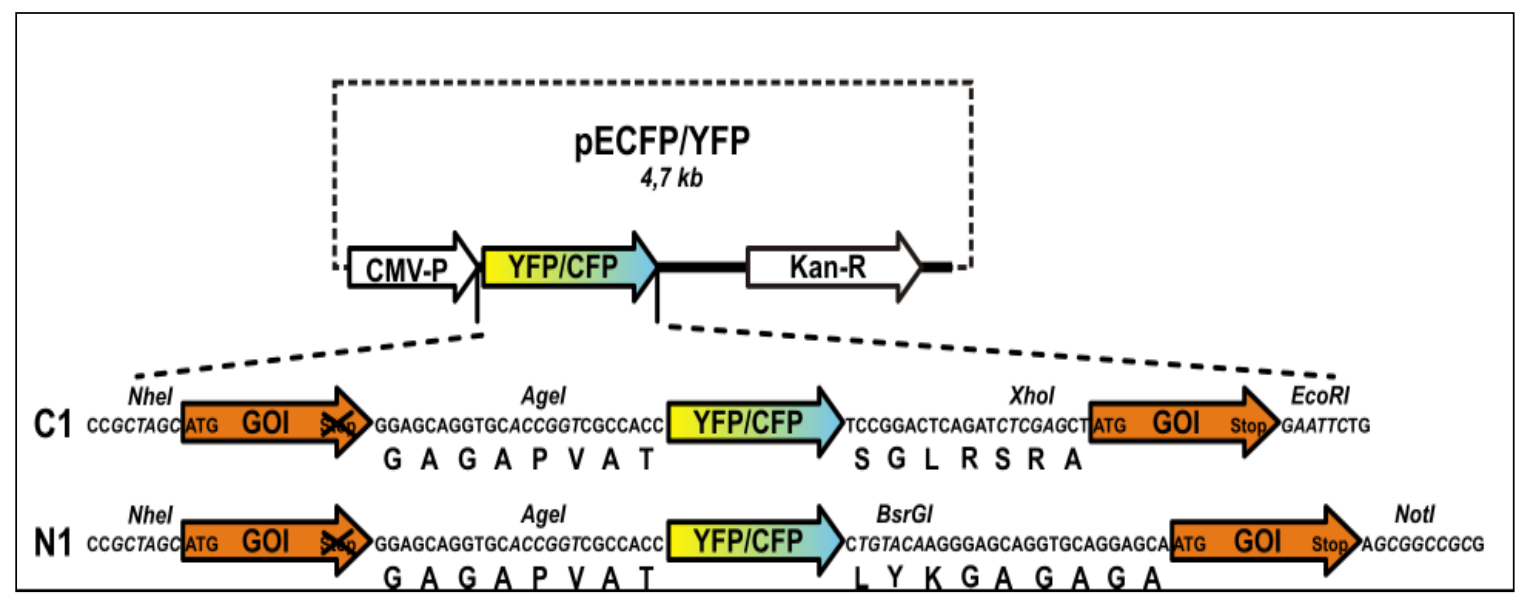


Figura 3.1. Esquema de clonagem das sequências dos diferentes genes nos vetores de expressão pECFP/YFP. As sequências de clonagem como os sítios de restrições Nhe I e Age I, são descritas no esquema acima, onde C1 corresponde a ligação do incerto amplificado no vetor, de expressão CFP, enquanto N1 corresponde à ligação do incerto amplificado no vetor, de expressão YFP. A sequência de aminoácidos GAGAPVAT é necessária para a ligação e fusão das proteínas celulares com os vetores pECFP/YFP, estas foram inseridas pelos primers no final da sequência, dos oligosnucleotideos.

\subsubsection{Clonagem}

A reação de ligação foi realizada utilizando-se $0,5 \mu \mathrm{g}$ de vetor digerido, $5 \mu 1$ de produto de PCR digerido, 10 unidades de T4 DNA ligase (Fermentas) juntamente com Taq DNA ligase (New England BioLabs) - para aumentar eficiência de formação de pontes fosfodiéster entre o extremo 5' fosfato com 3' hidroxil - e tampão da enzima T4 DNA ligase na concentração final de $1 \mathrm{X}$. A solução de ligação foi incubada a $20^{\circ} \mathrm{C}$ durante 3 horas. Para obtenção de clones contendo os genes das proteínas celulares e os diferentes alelos de Nef fusionados aos genes reporters, bactérias One Shot ${ }^{\circledR}$ TOP10 Chemically Competent E. coli foram transformadas com a reação de ligação pela técnica de choque térmico e posteriormente plaqueadas em meio LB-ágar (1,5\% de ágar bacteriológico, suplementado com $100 \mu \mathrm{g} / \mathrm{ml}$ de kanamicina). Após incubação à $37^{\circ} \mathrm{C}$ por 16 horas as colônias resultantes da seleção por antibiótico foram crescidas em $7 \mathrm{ml}$ de meio LB líquido suplementado com $100 \mu \mathrm{g} / \mathrm{ml}$ de kanamicina e submetidas a extração de DNA plasmideal por coluna pelo GeneJET ${ }^{\mathrm{TM}}$ Plasmid Miniprep Kit (Cat: \#K0501).

A confirmação da clonagem dos diferentes genes, previamente digeridos, foi realizada por eletroforese em gel de agarose, com posterior sequenciamento e análise de homologia em banco de dados BLAST - Basic Local Aligment (em anexo).

\subsubsection{Desenvolvimento de vetores lentivirais codificando shRNA para proteínas} celulares e alelos de Nef.

Os vetores lentivirais contendo as sequências dos shRNA específicos para o bloqueio das diferentes proteínas foram construídos em duas etapas. Num primeiro momento, vetor pSUPER-PGK-EGFP-NEO foi digerido com as enzimas de restrição Xho I e BamH I, juntamente com o vetor lentivrial pNL-SIN-CMV-BLR (gentilmente cedidos pelo Dr. Bryan R. Cullen do Howard Hughes Medical Institute). Um cassete foi liberado pelo vetor pSUPER, correspondendo à sequência PGK-EGFP-NEO. O vetor lentivrial pNL-SIN liberou o fragmento correspondente ao promotor $\mathrm{CMV}$ e à sequência que confere resistência ao antibiótico blastocidina (BLR). Em seguida, o cassete liberado pelo vetor plasmidial pSUPER foi ligado no vetor lentiviral pNL-SIN, obtendo-se o vetor lentiviral pNL-SIN-PGK-EGFP-NEO (Figura 3.2). 


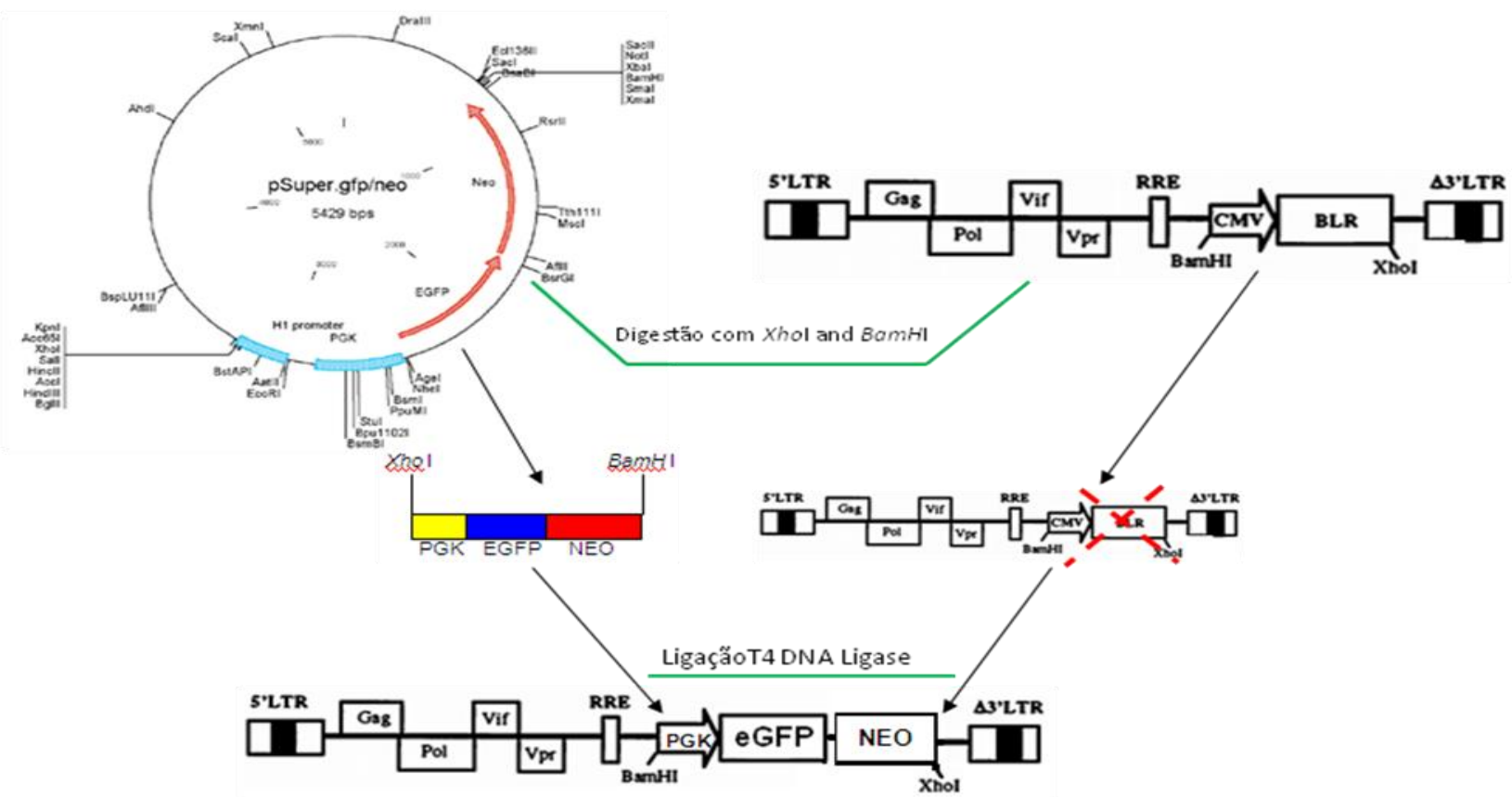

Figura 3.2. Construção do vetor lentiviral pNL-SIN-PGK-EGFP-NEO. Digestão dupla dos vetores, plasmidial pSUPER-PGK-EGFP/NEO e lentiviral pNL-SIN-CMV-BLR com Xho I e BamH I, seguida da ligação do cassete PGK-EGFP-NEO no vetor lentiviral pNL-SIN, formando o vetor lentiviral pNL-SIN-PGK-EGFP-NEO.

Posteriormente os vetores pSUPER-H1-shRNA codifocando os shRNA para as diferentes proteínas foram clonados no vetor lentivrial pNL-SIN-PGK-EGFP-NEO nos sítios Xba I e Cla I originando o vetor lentiviral pNL-SIN-EGFP-NEO-shRNA, carregando os shRNA específicos correspondentes à cada proteína (Figura 3.3). Os protocolos de clonagem utilizados se encontram descritos no tópico "3.2.1.3. Clonagem"

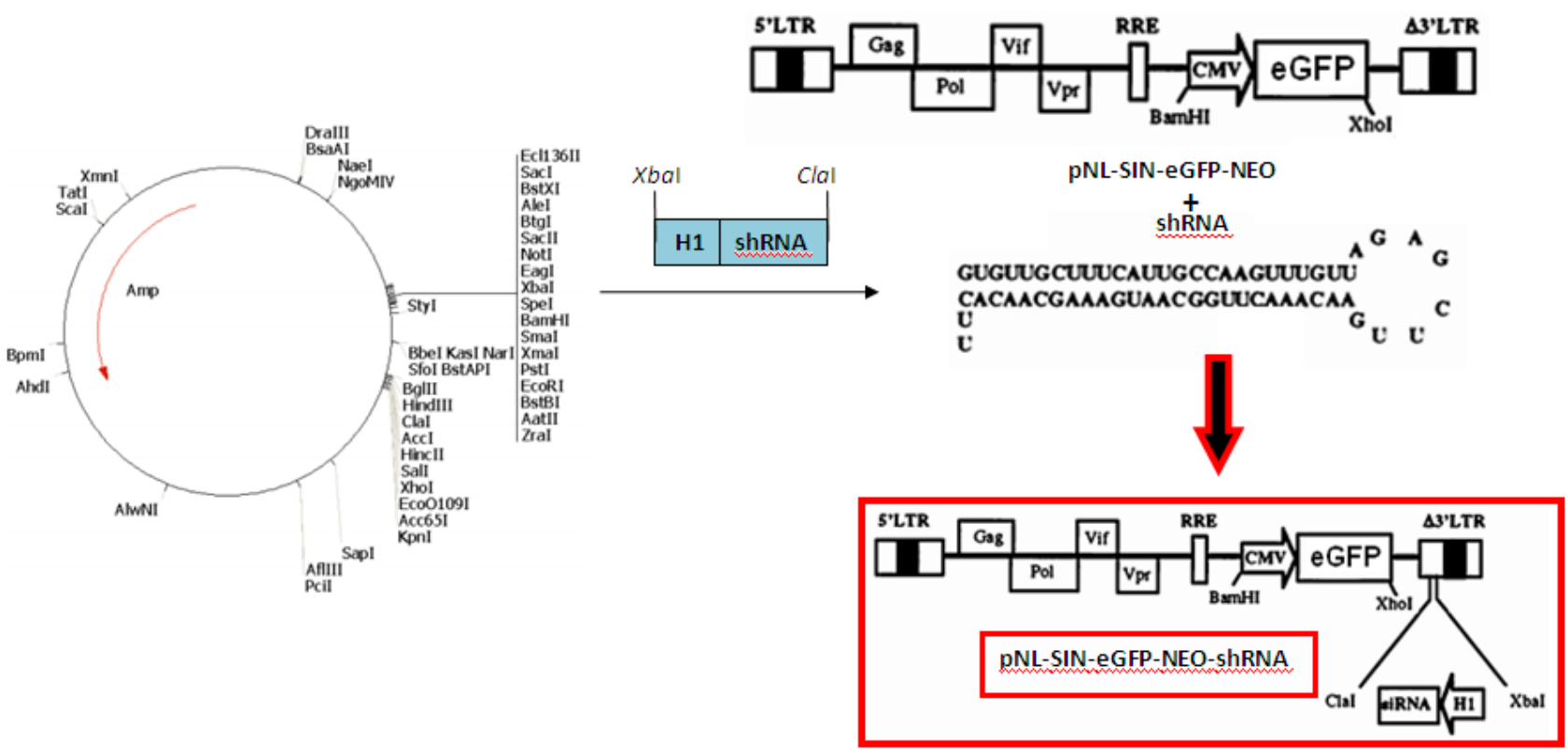

Figura 3.3. Construção do vetor lentiviral pNL-SIN-PGK-EGFP-NEO-shRNA. Após digestão dupla dos vetores, plasmidial pSUPER-PGK-EGFP/NEO e lentiviral pNL-SIN-CMV-BLR com as enzimas Xba I e Cla I os fragmentos contendo o promotor $\mathrm{H} 1$ e os correspondentes-shRNA foram clonados no vetor lentiviral pNL-SIN, formando o vetor lentiviral pNL-SIN-PGK-EGFP-NEO-shRNA. 


\subsection{Produção de partículas virais}

\subsubsection{Transfecção e quantificação de partículas virais.}

As partículas virias foram obtidas por transfecção de s células 293T pela técnica de precipitação de fosfato de cálcio. Resumidamente, 24 horas antes do experimento as células eram ressuspensas em solução de tampão fosfato (PBS) $1 \mathrm{X}$ e colocadas em placas de transfecção de seis poços a densidade de $4 \times 10^{5}$ células/poço em $2 \mathrm{ml}$ de meio de cultura DMEM suplementado.

Todos os experimentos foram realizados em triplicata. Para cada poço, 5 ug (quantidade total) de DNA plasmideal, distribuídas entre o vetor lentiviral (carregando os shRNA para as proteínas celulares) ou o vetor pBR (carregando diferentes alelos de Nef), pCTAT, pCREV e pVSV-G (em uma razão de 4,8;0,25;0,25;0,15 reespectivamente), foram diluídos na mistura de $125 \mu \mathrm{l}$ de água destilada e $125 \mu \mathrm{lde} \mathrm{CaCl}_{2}$ 0,5 M. Paralelamente, para a formação dos cristais de fosfato de cálcio, a solução contendo o DNA plasmideal foi acrescentada gota a gota a 250 $\mu \mathrm{l}$ de uma solução 2X HBS ( $\mathrm{NaCl} 280$ mM; KCl 10 mM; $\mathrm{Na}_{2} \mathrm{HPO}_{4} 1.5 \mathrm{mM}$; dextrose12 mM; Hepes $50 \mathrm{mM}$ ) sob agitação. Finalmente, a solução de transfecção foi espalhada gota a gota sobre a camada de células. Após 16 horas da transfecção, o meio de cultura antigo foi retirado e adicionado meio novo. Após 72 horas da transfecção, os sobrenadantes contendo as partículas virais foram recolhidos e estocados à $-86^{\circ} \mathrm{C}$.

A quantificação da produção das partículas lentivirais foi realizada pela técnica de ELISA utilizando o kit "HIV-1 p24 Antigen ELISA" (RETROtek ZeptoMetrix Corporation USA) e anticorpo específico para a proteína viral p24.

\subsection{Bloqueio da expressão gênica das proteínas celulares por shRNA}

\subsubsection{Transdução de células.}

O procedimento de feito para a análise do bloqueio de expressão proteica foi o mesmo que o utilizado para produção de partículas virais "3.3. Produção de partículas virais”, o sobreandantes foi recolhido e quantificado. $1 \times 10^{6}$ células $293 \mathrm{~T}$ plaqueadas em garrafas de $25 \mathrm{~cm}^{2}$, foram transduzidas com $1 \mathrm{~mL}$ de sobrenadante contendo as partículas virias codificando os shRNAs para as proteínas celulares numa concentração correspondente a aproximadamente $200 \mathrm{ng}$ de p24. Brevemente, as células foram lavadas duas vezes com PBS $1 \mathrm{X}$ e em seguida foram ressuspendidas em $1 \mathrm{ml}$ contendo as partícula virais. Após 4 horas incubadas à $37^{\circ} \mathrm{C}$ com $5 \%$ de $\mathrm{CO}_{2}$, foi adicionado $9 \mathrm{~mL}$ de meio DMEM+10\%SFB fresco. Finalmente, passadas 120 horas pós-transdução, estas células foram recolhidas e lisadas para WB. 


\subsubsection{Preparação do extrato protéico.}

A extração de proteínas celulares foi realizada através da adição de tampão RIPA (50 mM Tris-HCl, pH 7.4; $1 \%$ NP-40; 0.25\% deoxicolato de sódio; 150 mM NaCl; 1 mM EGTA; 1 $\mathrm{mM}$ PMSF; $1 \mu \mathrm{g} / \mathrm{ml}$ cada de aprotinina, leupeptina, pepstatina; $1 \mathrm{mM} \mathrm{Na} \mathrm{VO}_{4} ; 1 \mathrm{mM} \mathrm{NaF}$ ) sob vigorosa agitação e subsequente centrifugação a 14.500 rpm para eliminação de restos celulares que ficaram no fundo do tubo.

As determinações das concentrações de cada extrato proteico foram realizadas pelo método descrito por "Bradford Protocol - 1976" utilizando-se albumina sérica bovina (Sigma®) como padrão.

\subsubsection{Anticorpos utilizados.}

Os anticorpos utilizados neste trabalho se encontram listados abaixo (tabela 3.2), assim como suas respectivas companhias.

\begin{tabular}{llccc}
\hline Reagente & Produzido & Conjugado & Produzido & Número de catálogo \\
\hline Anti CD4 & camundongo & APC & BD Biosciences & 555347 \\
Anti hTEII & Coelho & - & Ab Cam & ab75070 \\
Anti B-COP1 & Coelho & - & Ab Cam & ab2899 \\
Anti ATP6V1H & Coelho & - & GeneTex & GTX110778 \\
Anti AP3 $\mu$ & Coelho & - & Ab Cam & ab87092 \\
Anti AP2 $\mu$ & camundongo & - & Santa cruz & sc-99026 \\
Anti AP1 $\gamma$ & Coelho & - & USBiological & A2298-48B
\end{tabular}

Tabela 3.2. Listagem de anticorpos. Lista de anticorpos utilizados, demonstrando em que animal foi produzido, se o anticorpo está conjugado com alguma enzima ou fluorocromo, a companhia produtora do reagente e o número de catálogo.

\subsubsection{Eletroforese e Immunoblotting.}

Aproximadamente $15 \mu \mathrm{g}$ dos diferentes extratos proteicos foram submetidos à eletroforese em gel de poliacrilamida na presença de dodecil sulfato de sódio (SDS-PAGE), sob condições desnaturantes e redutoras, conforme método originalmente descrito por "Laemmili Protocol - 1970”. Para isso utilizou-se o sistema de eletroforese vertical e os géis foram preparados com concentração de $10 \%$ para o gel separador e $4 \%$ para o gel concentrador (Current Protocols in Molecular Biology). As amostras foram diluídas em tampão de amostra 
5x (Tris-HCl 50 mM, pH 6,8; SDS 2\%; azul de bromofenol 0,1\%; $\beta$-mercaptoetanol (2-Me) 15 $\mathrm{mM}$ e glicerol 10\%) e fervidas por $5 \mathrm{~min}$. antes de serem aplicadas no gel. A eletroforese foi realizada em tampão de corrida (Tris- $\mathrm{HCl} 25 \mathrm{mM}, \mathrm{pH} 8,8$; glicina $250 \mathrm{mM}$ e SDS 0,1\%) à voltagem constante de $70 \mathrm{~V}$ e de $150 \mathrm{~V}$ durante a passagem das amostras pelo gel concentrador e separador, respectivamente. Como padrão de massas moleculares para o experimento de eletroforese, utilizou-se o marcador comercial da Bio-Rad: Precision Plus Protein Kaleidoscope Standards (MW: $10-250 \mathrm{kDa})$.

Após eletroforese, as proteínas foram transferidas para uma membrana de nitrocelulose em sistema semisseco de transferência horizontal (Trans-Blot SD Semi-Dry Transfer Cell, Bio$\mathrm{Rad})$, conforme as recomendações do fabricante. A transferência teve duração de 80 min. a corrente constante de $0,8 \mathrm{~mA} / \mathrm{cm}^{2}$, em tampão de transferência (Tris- $\mathrm{HCl} 48,4 \mathrm{mM}$; Glicna 39 mM; SDS 0,037\% e Metanol 20\%). Após a transferência, a membrana foi incubada em tampão de bloqueio (PBS 1X, Twen20 0,2\% e Leite em pó desnatado 5\%) por 1 hora a temperatura ambiente em agitação constante.

A membrana foi lavada três vezes em tampão de lavagem (PBS adicionado de Tween 20 , $2 \%$ ) e então incubado com o anticorpo primário especifico para cada proteína diluído 1:200 em PBS 1X contendo 1\% de leite em pó desnatado (PBS-Leite), por 1 hora. Após duas lavagens de 10 min. cada, com tampão de lavagem, a membrana foi incubada com o anticorpo secundário conjugado com fosfatase alcalina, na diluição de 1:2000 em tampão PBS Leite por 1 hora à temperatura ambiente. Após três lavagens com tampão de lavagem, de 10 min. cada, foi adicionado à membrana solução reveladora contendo $66 \mu \mathrm{l}$ de p-nitro azul tetrazólico (NBT) (Gibco-BRL) e $33 \mu \mathrm{l}$ de 5-bromo-4cloro-3-indolil-fosfato (BCIP) (Gibco-BRL) em $10 \mathrm{ml}$ de tampão Tris- $\mathrm{HCl}$ 100mM pH 9,5; $\mathrm{NaCl} 100 \mathrm{mM} ; \mathrm{MgCl}_{2} 5 \mathrm{mM}$. A reação de revelação foi interrompida com lavagens sucessivas com água destilada. As massas moleculares das proteínas eram conferidas de acordo com o marcador utilizado no gel.

\subsection{Avaliação da relevância fisiológica dos parceiros celulares de nef na modulação do receptor $\mathrm{CD} 4$}

\subsubsection{Infecção e Superinfecção}

$3 \times 10^{6}$. células SupT-1 foram infectadas com $1 \mathrm{~mL}$ de sobrenadante contendo as partículas virias codificando os shRNAs para as proteínas celulares numa concentração correspondente a aproximadamente $200 \mathrm{ng}$ de p24. Brevemente, as células foram lavadas duas vezes com PBS $1 \mathrm{X}$ e em seguida foram ressuspendidas em $1 \mathrm{ml}$ contendo as partícula virais. Passadas 4 horas de incubação à $37^{\circ} \mathrm{C}$ com $5 \%$ de $\mathrm{CO}_{2}$, foi adicionado $1 \mathrm{~mL}$ de meio 
RPMI+10\%SFB fresco e plaqueadas em placas de 6 poços. 48 horas pós-infecção foram adicionados $2 \mathrm{~mL}$ de meio RPMI+10\%SFB fresco em cada poço. Após 120 horas de incubação as células foram novamente lavadas e co-infectadas com $1 \mathrm{~mL}$ de vírus selvagem (WT) carregando os alelos de Nef (NL4.3), fusionadas com a proteína repórter BFP. Finalmente, após 96 horas pós-infecção, estas células foram recolhidas e analisadas por FACS.

\subsubsection{Citometria de Fluxo / "Sorting"}

\subsubsection{Determinação dos níveis de CD4}

Os níveis de expressão do receptor CD4 em células transduzidas com partículas virais expressando os diferentes shRNA e infectadas com vírus codificando o alelo NL4.3 de Nef foram quantificados por FACS 120 horas após a primeira infecção. Para isto as células foram lavadas duas vezes com solução de PBS 1X e incubadas por 45 min.s no gelo com o anticorpo anti-CD4-APC juntamente com o anticorpo anti-MHC-I-PE, ambos em concentração de $5 \mu \mathrm{L}$ /ml em PBS. Posteriormente, as células foram lavadas duas vezes com PBS 1X e ressuspensas em $200 \mu \mathrm{l}$ de PBS $+2 \%$ SFB. Os dados foram captados pela máquina FACS CANTO III, utilizando as seguintes florescências e seus respectivos filtros: GFP (530/30), BFP (470/15), PE (585/42) e APC (660/20). Os resultados foram analisados com o programa Diva (BD Biosciences).

O isolamento de linfócitos de sangue periférico foi realizado de acordo como descrito em [223]. Brevemente, células mononucleares do sangue periférico purificadas com ficollperiférico (PBMC) foram isoladas a partir de dadores saudáveis e cultivadas em RPMI 1640 suplementado com 10\% de soro AB humano. As células PBMCs foram activadas com $5 \mathrm{ng} / \mathrm{ml}$ de fito-hemaglutinina (PHA) durante 2 dias, anteriores à transdução de vectores lentivirais ou a infecção com vírus do HIV-1. Após a estimulação de PHA, as células foram mantidas em meio RPMI 1640 suplementado com 10\% de soro AB humano contendo $50 \mathrm{U}$ de interleucina-2 (IL2) / ml. Todos os meios de cultura utilizados aqui foram suplementadas com $100 \mathrm{U}$ de penicilina / ml, 100 ug de estreptomicina / ml, piruvato de sódio $1 \mathrm{mM}$ e $2 \mathrm{mM}$ de glutamina.

\subsection{Fluorescence Resonance Energy Transfer - FRET}

\subsubsection{Transfecção de células para ensaios de FRET}

Células $293 \mathrm{~T}$ foram transfectadas por técnica de fosfato de cálcio (técnica citada no tópico “3.4.1. Transfecção de células”), onde $1,5 \times 10^{5}$ células foram plaqueadas em placas de 12 poços com $1 \mathrm{~mL}$ de meio de cultura DMEM suplementado. Para cada poço, 2,5 $\mu \mathrm{g}$ (quantidade total) de DNA plasmideal foram distribuídas, sendo 1,25 $\mu \mathrm{g}$ do vetor CFP e 1,25 
$\mu \mathrm{g}$ do vetor YFP, fusionados às sequências de genes que expressam as diferentes proteínas celulares. Após 24-36 horas os sobrenadantes dos poços foram descartados e as células foram recolhidas e lavadas duas vezes com PBS+EDTA. Após a última lavagem, as células foram ressuspensas em $200 \mu \mathrm{l}$ de paraformaldehido $2 \%$ à $4^{\circ} \mathrm{C}$.

\subsubsection{Frequence Resonance Energy Transfer (FRET/FACS).}

Nas medições de FACS/FRET foram feitas utilizando o aparelho FACS CANTO III (BD Bioscience) equipado com os lasers de $405 \mathrm{~nm}, 488 \mathrm{~nm}$ e $633 \mathrm{~nm}$.

Para medir ECFP e FRET as células foram excitadas com o laser de $405 \mathrm{~nm}$. O resultado foi "plotado" no canal ECFP com o filtro padrão 450/40, enquanto o sinal de FRET foi medido com o filtro 529/24 (Semrock). Para medir EYFP, as células foram excitadas com o laser de 488nm, entretanto a emissão também era captada no filtro 529/24 (Semrock).

Na figura 3.4, abaixo, estão descritos os padrões utilizados para medir os níveis de
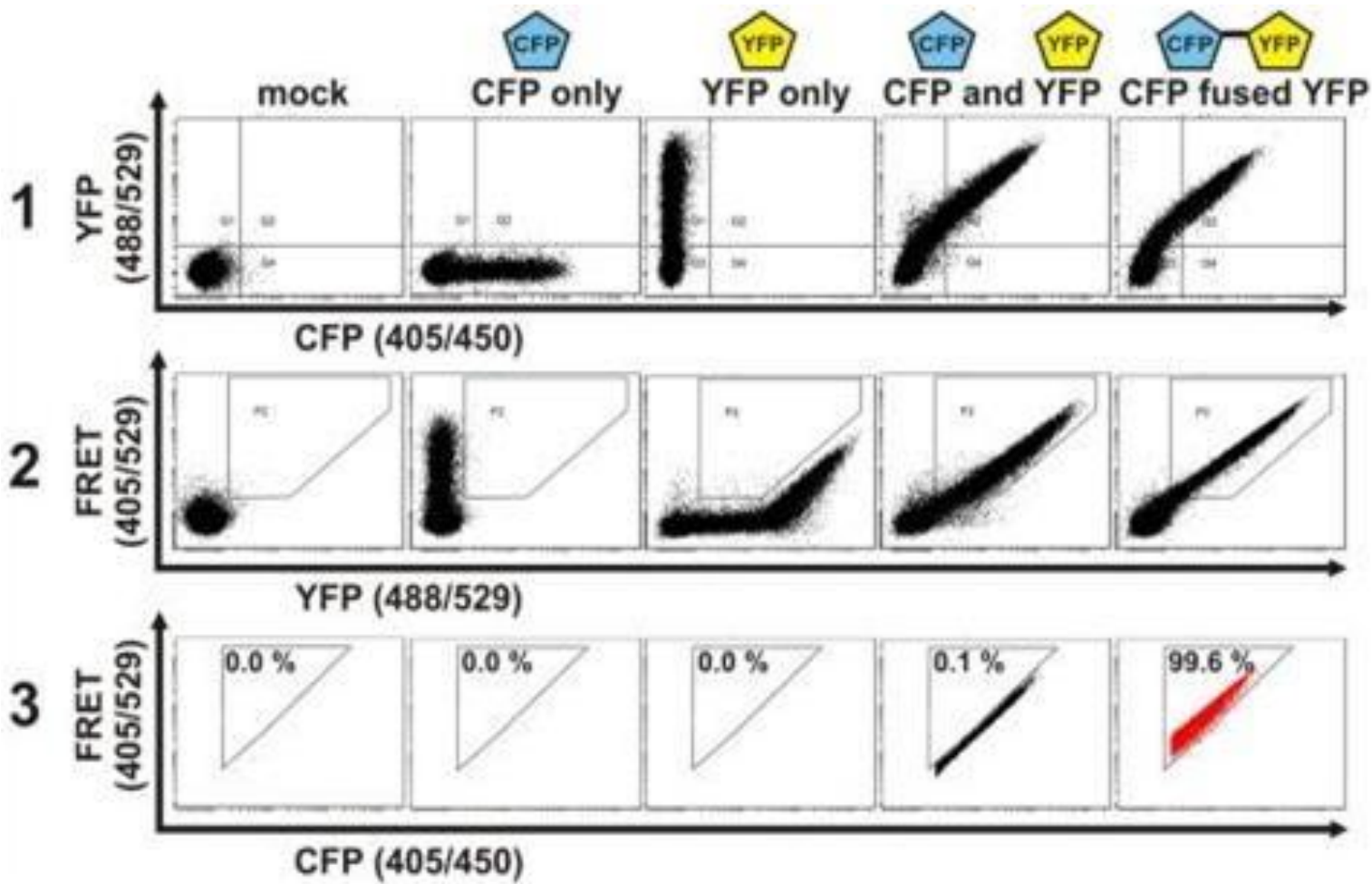

FRET expressos pelas proteínas.

Figura 3.4. Estratégia para medir FRET por FACS. Células $293 \mathrm{~T}$ transfectadas com os controles; apenas CFP, apenas YFP, CFP mais YFP e CFP-YFP fusionadas, foram analisadas por FACS. As células duplo-positivos foram captadas no painel 1, enquanto o falso positivo sinal de FRET, resultado da excitação de YFP ao laser de 405nm, foi excluída no painel 2. Os "plots" com as células restantes foram ajustados para conter apenas as células CFPYFP fusionadas, controles para o sinal de FRET positivo.

\subsection{Microscopia Confocal}

\subsubsection{Transfecção de células para experimentos de microscopia confocal}

Os experimentos de microscopia confocal foram realizados da seguinte maneira: antes 
das células serem plaqueadas para transfecção foram colocadas lamínulas circulares de vidro no fundo de cada poço de placas de seis poços. Posteriormente foram plaqueadas 500.000 células acima de cada lente e 24 horas mais tarde foram realizadas as transfecções, como descrito no tópico “3.6.1. Tansfecção de células para FRET”. De 36 a 48 horas após as transfecções, as lentes foram recolhidas, lavadas em PBS+ paraformaldeído $4 \%$ tamponado a $4^{\circ} \mathrm{C}$, e montadas em lâminas com solução de mowiol (2,4 g polyvinylalcohol, $6 \mathrm{~g}$ de Glicerina e $18 \mathrm{~mL}$ de PBS). As diferentes preparações foram mantidas ao abrigo da luz e umidade até análise, por até 15 dias.

\subsubsection{Imagens de microscopia confocal}

O microscópio utilizado para obter as fotos foi Zeiss LSM510 Meta, e o programa usado para a formatação e captura das imagens foi o software "ImageJ plug-in" [224]. 


\section{Capítulo 4. Resultados e Discussão}


A diminuição da expressão do receptor CD4 da superfície da célula infectada é uma das principais características de infecção pelo vírus da imunodeficiência adquirida humana (HIV-1) [225], [226]. Resultados obtidos por vários grupos inclusive o nosso, mostraram uma clara relação entre a capacidade de diminuir a expressão do receptor viral CD4 e o aumento da infecsiosidade e replicação viral, observados nos estágios finais da infecção, sugerindo a participação deste fenômeno na patogênese e progressão da doença [88], [91]. Nosso grupo mostrou claramente que a inibição da modulação da expressão de CD4 mediada por Nef pode representar um novo alvo terapêutico [222]. Dos três genes virais estão envolvidos com esta função Nef desempenha o papel mais importante na diminuição da expressão de CD4, aumentando a internalização da proteína CD4 sinalizando para degradação lisossomal [48], [227]. Diversas proteínas celulares foram envolvidas na modulação de CD4 mediada por Nef, dentre estas proteínas, o complexo adaptador de clatrina heterotetramérico AP-1 e AP-2 [123], [95], [97], a thioesterase humana (AcoT8), a ATPase (bomba de prótons) vacuolar V1H, a proteína de revestimento formadora de vesículas $(\beta-\mathrm{COP})$, a tirosina cinase, Hck e as proteínas Espn15 e Dynamina 2, foram descritas como necessárias neste mecanismo [129], [228], [126].

Experimentos anteriores para validar o papel de algumas destas proteínas foram realizados usando versões mutantes dominantes, onde a superexpressão das mesmas levou a inibição da função das proteínas endógenas, a qual às vezes foi acompanhada de uma alteração na modulação de CD4 mediada por Nef. No entanto estes estudos não foram validados quanto a sua relevância fisiológica no contexto da infecção viral.

Recentemente, a técnica de short hairpin RNA (shRNA) tem sido utilizada para o estudo da função de inúmeras proteínas em células de mamíferos, silenciando a expressão de genes específicos. Por outro lado, recentemente foi desenvolvida outra poderosa ferramenta para avaliar, quantificar, e caracterizar a interação entre proteínas. Esta técnica baseia-se na análise dos níveis de freqüência relativa de energia transferida (FRET) por meio de citometria de fluxo (FACS) (FACS/FRET) [204].

Neste contexto, e mediante o uso das técnicas de RNA de interferência (RNAi) e (FACS/FRET) nós traçamos como objetivo geral deste trabalho determinar a relevância fisiológica dos putativos parceiros celulares da proteína viral Nef na degradação do receptor CD4.

\subsection{Construção de Vetores}

\subsubsection{Construção de vetores de expressão de proteínas de fusão.}


No primeiro momento os diferentes cDNAs de cada proteína celular, AcoT8, V1H, ßCOP, Ap1 $\sigma$, Ap2 $\sigma, A p 2 \mu$ e CD4, juntamente com alelos da proteína Nef (NA7, mac239, e NL4.3), foram fusionados aos genes codificando as proteínas fluorescentes CFP e YFP (fluorescência ciano e amarela respectivamente) e presentes nos vetores pECFP e pEYFP, respectivamente (gentilmente cedidos pelo Dr. Michael Schindler do Heinrich-Pette-Institut an der Universitat Hamburg).

A especificidade dos diferentes fragmentos amplificados correspondentes aos diferentes genes celulares e virais foi confirmada por eletroforese em gel de agarose e posterior sequênciamento e alinhamento com as sequências de aminoácidos da versão selvagem de cada proteína celular (Anexo I), obtendo-se assim a confirmação da correta amplificação e clonagem dos cDNAs que codificam as proteínas de interesse.

A correta clonagem dos diferentes fragmentos amplificados foi confirmada por digestão dos vetores pEYFP / pECFP com as enzimas de restrição Nhe I e Age I e subsequiente analise em gel de agarose, o que permitiu evidenciar a liberação de fragmentos de tamanho correspondente a sequência de cada gene clonado. (Figura 4.1).

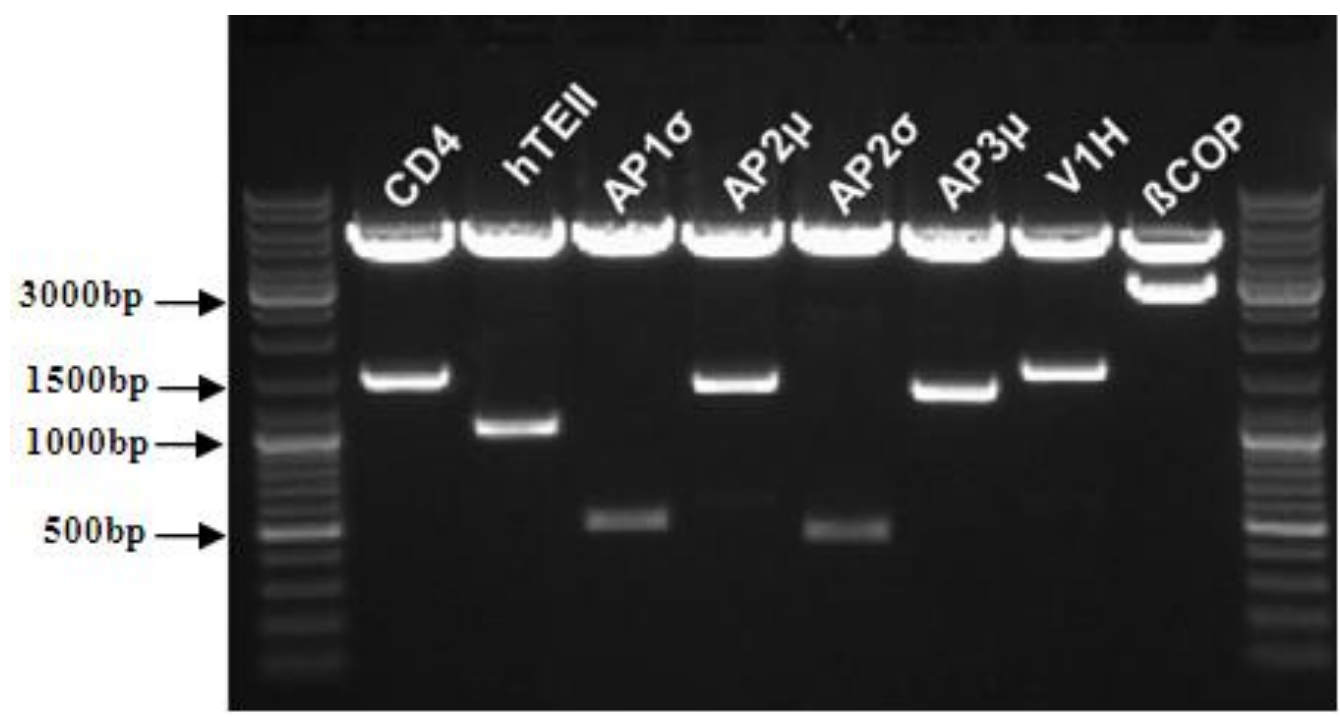

Figura 4.1. Confirmação da construção de vetores de expressão pECFP contendo as diferentes sequências correspondentes aos genes celulares. Os diferentes cDNAs correspondentes as diferentes proteínas celulares foram amplificadas por PCR usando oligonucleotídeos contendo sequências para as enzimas NheI e AgeI. Após a amplificação os fragmentos foram digeridos e clonados nos vetores pEYFP e pECFP. A confirmação da clonagem foi obtida por digestão com as enzimas de restrição NheI e $A g e \mathrm{I}$ e os fragmentos liberados tiveram seu peso molecular comparado com o marcador "GeneRuler DNA Ladder Mix", o que mostrou os tamanhos de fragmentos esperados.

\subsection{Expressão de proteínas celulares fusionadas}


Para confirmar a expressão e localização das proteínas celulares. Células 293T foram transfectadas e analisadas após 36 horas com as diferentes proteínas fusionadas a proteína CFP, por esta ser a florescência melhor captada na microscopia confocal e pelo mesmo motivo a fluorescência para a identificação visual foi em vermelho (Figura 4.2).

CD4

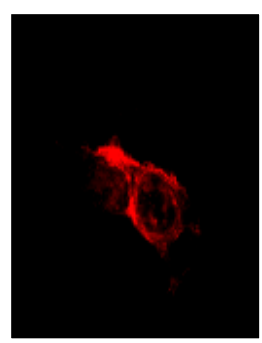

AP1 $1 \sigma$

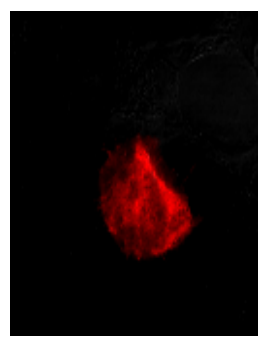

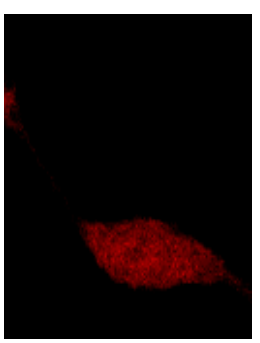

AP2 $\mu$

AP2 $\sigma$

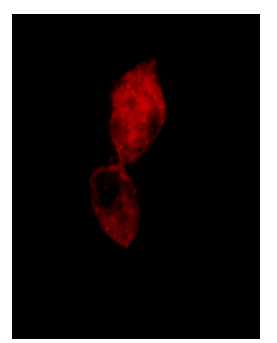

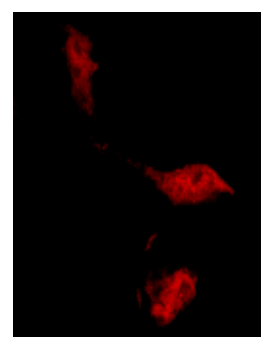
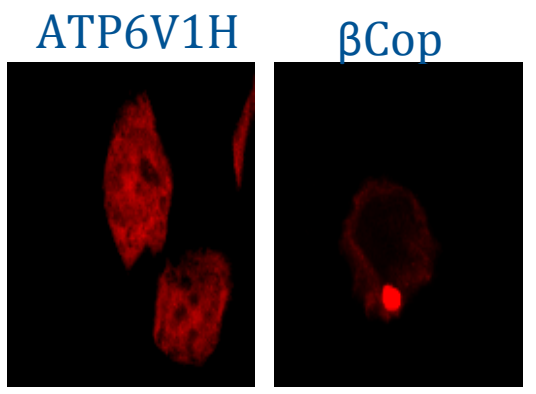

Figura 4.2. Expressão e localização celular de proteínas de fusão. Células $293 \mathrm{~T}$ foram transfectadas apenas com DNAs de vetores expressando as proteínas celulares fusionadas à CFP. A expressão das difeents proteínas foi detectada por Microscopia Confocal.

Como pode ser observado na figura 4.2 foi possível confirmar a expressão e localização das proteínas de fusão com descrito na literatura [165], mostrando que a fusão à proteína "repórter” não afetou a localização endógena das proteínas celulares em estudo.

Enquanto as proteínas: AcoT8, Ap $1 \sigma, \mathrm{Ap} 2 \mu, \mathrm{AP} 2 \sigma$ e V1H, mostraram uma expressão uniformemente distribuída no citoplasma da célula, as células transfectadas com o vetor para expressão de CD4 mostrou uma concentração maior da proteína na membrana celular, enquanto a proteína $\beta \mathrm{COP}$ apresentou uma maior concentração próximo ao núcleo da célula e uma pequena fração na membrana celular.

\subsection{Caracterização da interação entre proteínas celulares e virais}

Com o intuito de determinar o nível de interação das diferentes proteínas celulares com os diferentes alelos da proteína Nef e com a proteína CD4, foram realizados ensaios de FRET entre as proteínas celulares fusionadas a proteína ciano-fluorescente CFP e os alelos da proteína Nef (NA7, Mac239 e NL4.3) e o receptor celular CD4 fusionados a proteína amarelofluorescente YFP.

Tendo em vista que as proteínas de expressão CFP e YFP, não têm afinidade entre si, células $293 \mathrm{~T}$ foram transfectadas com ambos os vetores servindo estas como controle negativo em todos os experimentos de FRET ( $0 \%$ de FRET). Por outro lado, para obter um controle positivo mostrando o máximo de interação entre duas proteínas (100\% de FRET), foram fusionadas as duas proteínas de expressão, CFP com YFP, e transfectadas em células 293T. Estes dois controles foram adotados, como parâmetros de mensuração de FRET (0\% e 100\%).

\subsubsection{Interação entre proteínas celulares e o alelo NA7 da proteína Nef}


Como descrito anteriormente células $293 \mathrm{~T}$ forma co-transfectadas com os vetores de expressão, expressando as proteínas celulares fusionada à fluorescência CFP juntamente com o vetor expressando o alelo NA7 da proteina Nef fusionado a fluorescência YFP. Após 36 horas a interação entre as proteínas celulares e a proteína Nef-NA7 foi analisada por FACS/FRET.

A figura 4.3 mostra os diferentes níveis de interação detectados entre cada proteína celular e o alelo NA7 de Nef expressos como porcentagem de interação. O relativo baixo nível de interação entre o receptor CD4 e Nef-NA7 (39\%), pode ser explicado pela modulação de CD4 pela própria proteína viral, o que levaria a uma queda drástica do sinal detectado. Entretanto foi possível observar uma grande afinidade entre as proteínas Nef-NA7 e a proteína responsável pela depalmitoilação do receptor CD4, a thiosterase II. A interação entre estas duas proteínas atingiu porcentagens de aproximadamente $90 \%$ de sinal de FRET positivo, quando comparada ao controle positivo CFP+YFP, o que traz uma informação importante a respeito da interação de AcoT8 com este alelo de Nef, dado que não existia informação até o momento na literatura [165], [128], [129], [229], [230], [231], [232]. A proteína formadora do complexo clatrina $\mathrm{AP} 2 \mu$, uma das principais responsáveis pela reciclagem endógena do receptor CD4, também mostrou um nível de interação com o alelo NA7 (40\%). O que vem a confirmar dados da literatura que mostram a direta interação da subunidade desta proteína com a proteína viral [148], [109], [143].

Outra proteína que mostrou uma pequena, mas significantiva interação com Nef NA7 foi à proteína $\beta C O P(30 \%)$. É importante salientar que embora não existam dados conclusivos da participação desta proteína na modulação de CD4 mediada por Nef existe uma forte evidencia de sua participação na reciclagem endógena de CD4 na formação de endossomos primários e secundários [149], [150], [151], [95].

Finalmente as proteínas AP1 $\sigma$, AP2 $\sigma$ e V1H não mostraram uma interação relevante com Nef-NA7. A ausência de interação entre Nef-NA7 e as proteínas AP1 $\sigma$ e AP2 $\sigma$, vem a confirmar dados da literatura no sentido de ausência de qualquer tipo de ligação entre estas proteínas celulares com alelos de Nef e a reciclagem endógena de CD4. Já a bomba de prótons ATP6V1H (V1H), foi descrita como uma importante parceira de Nef no processo de modulação de CD4, sendo responsável pela acidificação dos endossomos que carregam moléculas de CD4 [113], [228] o que sugere que esta proteína celular poderia participar deste fenômeno não por interação direta com Nef, mas sim de uma forma indireta, talvez interagindo com proteínas presentes no complexo de reciclagem do CD4, como a proteína Ap2. 


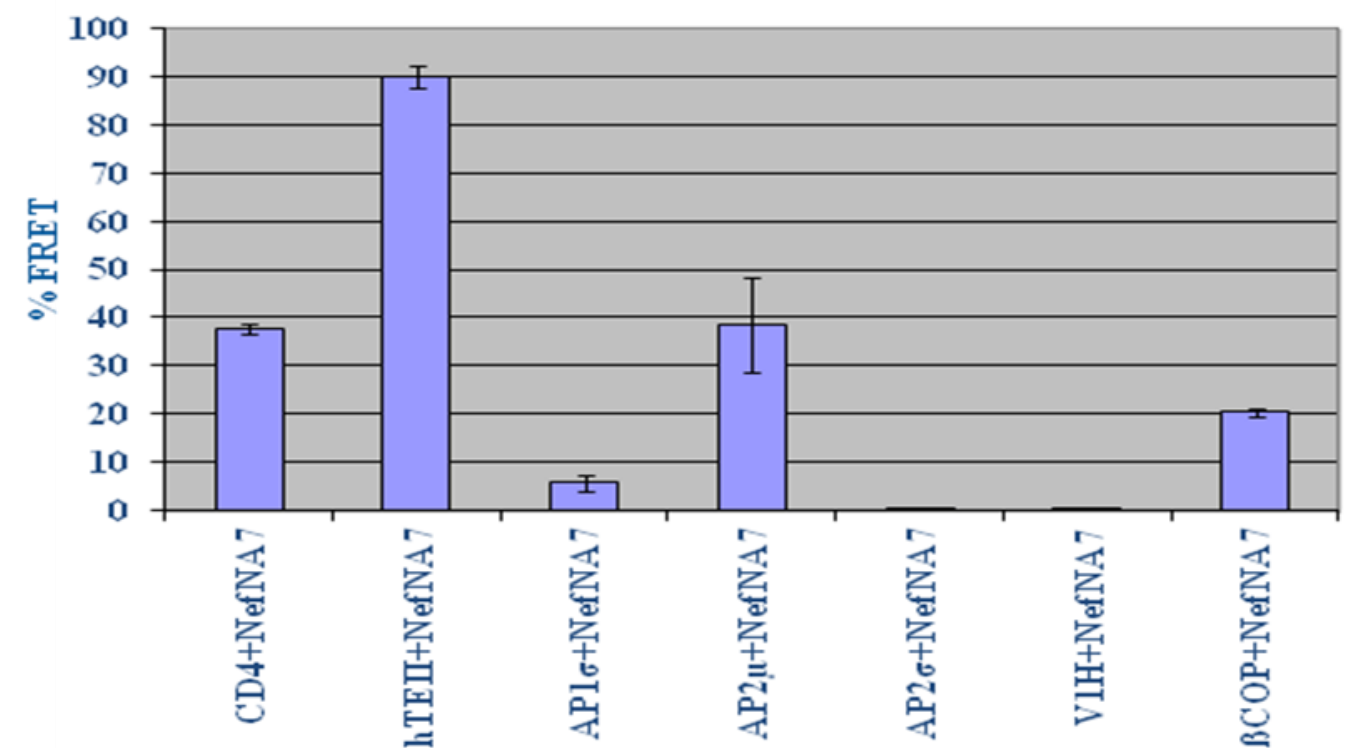

Figura 4.3. Caracterização da interação entre as proteínas celulares e a proteína Nef-NA7 por FRET. Após co-transfecção de células $293 \mathrm{~T}$ com vetores de fusão expressando as proteínas celulares e o alelo Nef- NA7, foram medidos os níveis de FRET entre elas. As proteínas celulares CD4, AcoT8, AP2 $\mu$ e $\beta$ COP, mostraram diferentes níveis de interação com o alelo NA7 da proteína Nef $(39 \%, 89 \%, 45 \%$ e $30 \%$, respectivamente), enquanto AP1 $\sigma$, AP2 $\sigma$ e V1H, não mostraram interação direta com o alelo de Nef.

\subsubsection{Interação entre proteínas celulares e o alelo $N$ L4.3 da proteína Nef}

A figura 4.4 mostra os diferentes níveis de interação entre as proteínas celulares com o alelo NL4.3 da proteína Nef, cepa de referencia mais frequentemente do subtipo B.

Embora o padrão de interação com as diferentes proteínas celulares tenha sido similar ao observado com o alelo NA7, os níveis foram significativamente menores.

A menor interação com a molécula CD4 (22\%) poderia obedecer a uma menor afinidade deste alelo pela molécula CD4 ou uma maior capacidade deste alelo em degradar CD4.

Segundo Ornelas, a cepa NL4.3 da proteína Nef induz uma maior modulação da molécula de CD4, quando comparada a cepa Nef-NA7 em células 293T transfectadas com plasmídeo codificando ambas as proteínas [193]. Esta informação reforça a idéia que a menor interação detectada entre o receptor CD4 e o alelo NL4.3 seria devido na verdade a uma maior degradação do receptor. Por outro lado embora o nível de interação com a AcoT8 tenha sido substancialmente alto (64\%), também foi menor ao observado com o alelo NA7. Sabendo que o sítio de ligação de AcoT8, no alelo Nef-NL4.3 ( $\mathrm{D}_{123}$ ) [128], é conservado em ambos os alelos [165], descarta-se a possibilidade de uma maior afinidade entre AcoT8 e Nef-NA7 por uma alteração na sequência de aminoácidos deste alelo. No entanto, já se encontra bem descrito na literatura que a modulação do receptor CD4, mediada por Nef é resultado da interação entre o receptor CD4, o alelo de Nef e um complexo formado por proteínas celulares [225], o que sugere que mesmo AcoT8 tendo uma interação com Nef-NL4.3 menor do que com Nef-NA7, a maior modulação de CD4 por Nef-NL4.3 pode-se dever a uma maior interação com outras proteínas celulares também envolvidas neste fenômeno, mas sem descartar a interação inicial 
entre CD4 e AcoT8 [129]. Uma alternativa seria que a interação entre este alelo e AcoT8 "in vivo" seja aumentada pela presença de outras proteínas celulares.

Similarmente aos resultados obtidos com o experimento anterior a interação com as proteínas AP2 $\mu$ e $\beta$ COP $(16 \%$ e $12 \%$, respectivamente) foram menores aos observados com o alelo NA7, sendo a interação com $\beta C O P$ quase não significativa. Estes resultados, não significam necessariamente que estas proteínas sejam menos importantes na modulação de CD4 mediada por este alelo, desde que existe uma importante evidencia na literatura a respeito da participação das mesmas na degradação de CD4. [171], [174],[123],[78]. Com base nestes trabalhos embora a baixa interação detectada entre AP2 $\mu$ e $\beta$ COP e o alelo Nef- NL4.3 não seria possível descartar a participação das mesmas na modulação negativa do receptor CD4 por este alelo.

Os níveis de interação com as proteínas celulares AP1 $\sigma, A P 2 \sigma$ e V1H, foram negativos similarmente aos observados com o alelo NA7.

Finalemente na interpretação dos resultados acima descritos é importante se considerar que a baixa interação entre algumas proteínas celulares e os alelos de Nef do HIV-1 pode obedecer a ausência da molécula CD4, desde que as células 293T usadas nos ensaios não expressam este receptor, o qual poderia ser um fator potencializador, na interação das proteínas celulares e Nef.

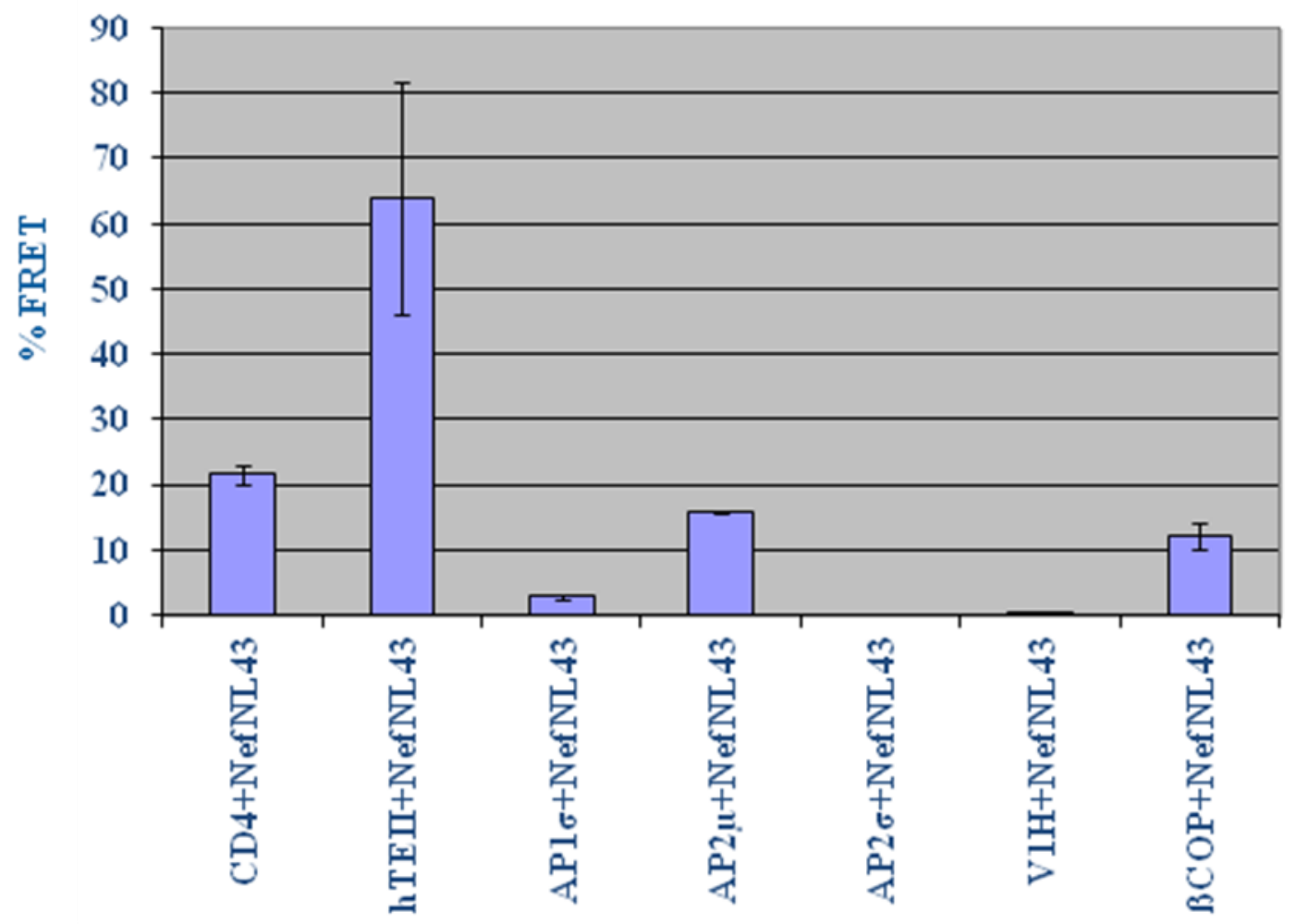

Figura 4.4. Níveis de interação direta entre as proteínas celulares e a proteína Nef NL4.3 por \% de FRET. Co-transfecção de células 293T com vetores de fusão expressando as proteínas celulares e o alelo Nef- NL4.3. O 
resultado da interação entre as proteínas celulares e o alelo NL4.3, medida por FRET, mostra de uma maneira geral uma redução desta interação pelas proteínas CD4, AcoT8, AP2 $\mu$ e $\beta C O P,(22 \%, 64 \%, 16 \%, 12 \%$, respectivamente) quando comparadas com o alelo Nef- NA7, o que mostra uma menor iteração com as proteínas celulares, entretanto talvez uma maior modulação de CD4.

\subsubsection{Interação entre proteínas celulares e o alelo Mac239 da proteína Nef do SIV}

Também foram avaliados os níveis de interação das proteínas celulares com a variante Mac239 de Nef presente no vírus da imunodeficiência simiana (SIV). Ao gene codificando este alelo foi fusionado o gene codificando a florescência YFP e o vetor resultante cotransfectado em células 293T, juntamente com os vetores codificando as proteínas celulares fusionadas a florescência CFP.

Como pode ser observado na figura 4.5 , os padrões de interação entre as proteínas celulares e esta variante de Nef foram diferentes aos obtidos com as variantes presentes no HIV-1. As únicas proteínas que mostraram relevante interação com este alelo foram CD4 e AP2 $\mu$. Sendo que o nível de interação entre a proteína CD4 (13\%) foi menor aos níveis observados com os outros alelos de Nef.

Por outro lado, quando comparada a sequência do alelo Nef- Mac239 de SIV com os demais alelos da proteína Nef do HIV-1 (NL4.3, NA7 e SF2), na figura 1.8, pode-se perceber alterações nos aminoácidos triptofano de posição $57\left(\mathrm{~W}_{57}\right)$ e leucina na posição 58 ( $\left.\mathrm{L}_{58}\right)$, correspondentes ao sítio de ligação entre a proteína Nef e o receptor CD4, os quais são altamente conservados nos alelos da proteína Nef do HIV-1, [165]. Por outro lado em outras regiões desta sequência é possível observar um alto número de inserções/alterações de aminoácidos, como na posição inicial do triptofano em $70\left(\mathrm{~W}_{70}\right)$, a alteração da leucina na posição $71\left(\mathrm{~L}_{71}\right)$ por uma arginina $\left(\mathrm{R}_{71}\right)$, como mostrado por Roeth em 2006. Estas alterações podem estar diretamente relacionadas com o alto nível de modulação de CD4 pelo alelo NefMac239 de SIV (87\%), observados por Ornelas, S., 2007 [193].

Outro fator que poderia ter influenciado na baixa interação entre este alelo e a proteína CD4 poderia ser a diferença nas sequências entre as versões desta proteína presentes em primatas humanos e não humanos.

Entretanto, a interação detectada entre o alelo Nef-Mac239 e a proteína celular AP2 $\mu$ foi claramente maior à observada com os alelos anteriores (89\%), o que poderia ser um fator importante na maior capacidade deste alelo de degradar CD4. Por outro lado esta maior interação vem a confirmar dados da literatura a respeito do critico papel desempenhado por esta proteína na endocitose de CD4 mediada por Nef [171], [174], [123], [78]. 
Esta maior afinidade entre o alelo Nef- Mac239 e a proteína celular AP2 $\mu$, talvez possa ser atribuída às diferenças apresentadas por este alelo no domínio de ligação a AP2 [165] (EXXXLL ${ }_{165}$ ) presente no alelo NL4.3[148], [113], [143]. Já o sítio de ligação desta proteína em Mac239, se encontra da posição 187 à posição 192 com a deleção da leucina 191(-191) e a alteração da leucina encontrada na posição $192\left(\mathrm{~L}_{192} \mathrm{Y}\right)$ por uma tirosina $\left(\mathrm{Y}_{192}\right),\left(\mathrm{EXXX}-\mathrm{Y}_{192}\right)$ [165], como pode ser obsevado no alinhamento da figura 1.8. Dessa forma estas alterações podem estar potencializando o nível de interação entre o alelo Nef-Mac239 e a proteína celular AP2 $\mu$, induzindo assim ao aumento do sinal de FRET.

Já a proteína AcoT8, que mostrou ser a proteína celular com mais afinidade com os alelos de Nef do HIV-1 não mostrou interagir, ao menos diretamente, com a variante NefMac239, o que poderia ser explicado por diferenças na sequencia entre variantes presentes em primatas humanos e não humanos. [233], [234]. Já a alta afinidade entre a proteína celular com variantes presentes no HIV-1, coloca em evidencia a alta capacidade de adaptação deste vírus a diferentes hospedeiros usufruindo de novas proteínas celulares com objetivo de garantir uma alta eficiência em mecanismos patogênicos críticos a sua sobrevivência no novo hospedeiro.

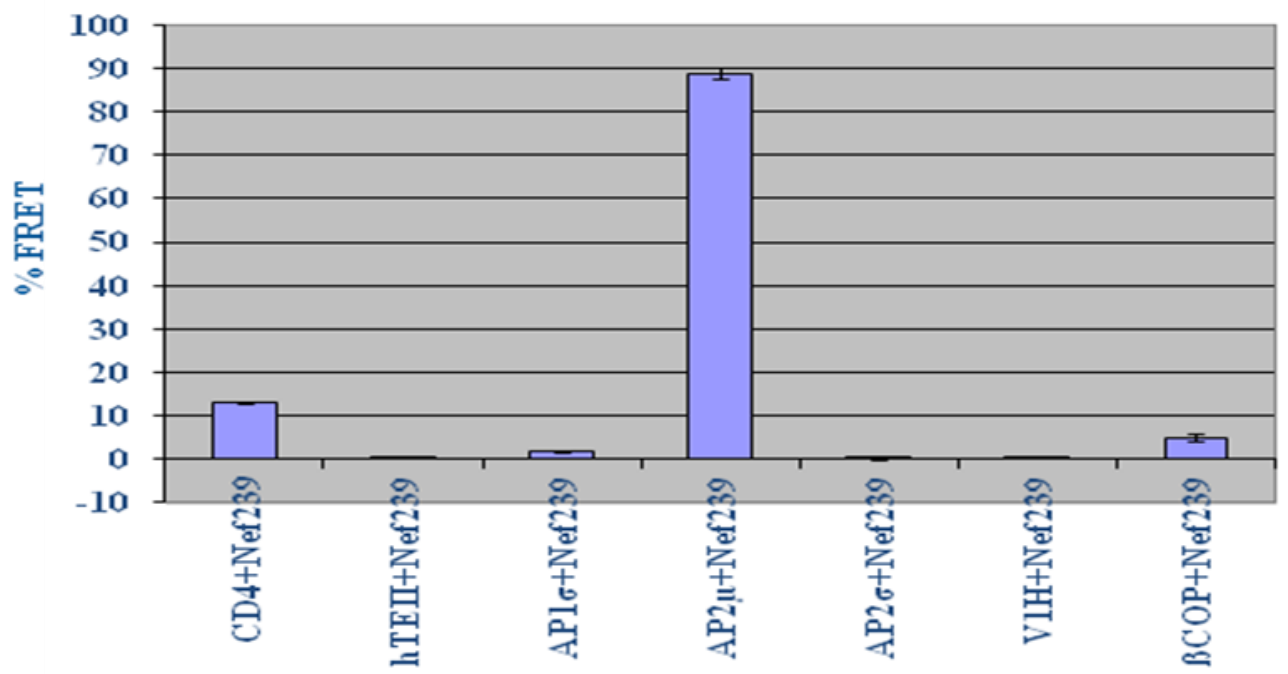

Figura 4.5. Níveis de interação direta entre as proteínas celulares e a proteína Nef-Mac239 por \% de FRET. Foi feita a co-transfecção de células $293 \mathrm{~T}$ com vetores de fusão expressando as proteínas celulares e a variante Nef-Mac239 de SIV. Diferentemente dos experimentos anteriores, Nef-Mac239 de SIV mostrou interação significativa apenas com CD4 e AP2 $\mu$ (13\% e $89 \%$, respectivamente), principalmente a última. Sendo que a interação com a proteína CD4 possa estar baixo justamente pelo nível de modulação do receptor celular ou também as variações na sequência de aminoácidos desta variante.

\subsubsection{Interação entre proteínas celulares e o receptor CD4}

Por fim e com objetivo de avaliar as possíveis interações entre o receptor celular CD4, e as outras proteínas celulares, células 293T foram co-transfectadas com a proteína CD4 fusionada a fluorescência YFP, juntamente com as proteínas celulares fusionadas a CFP, incluindo a própria molécula de CD4 (Figura 4.6). 


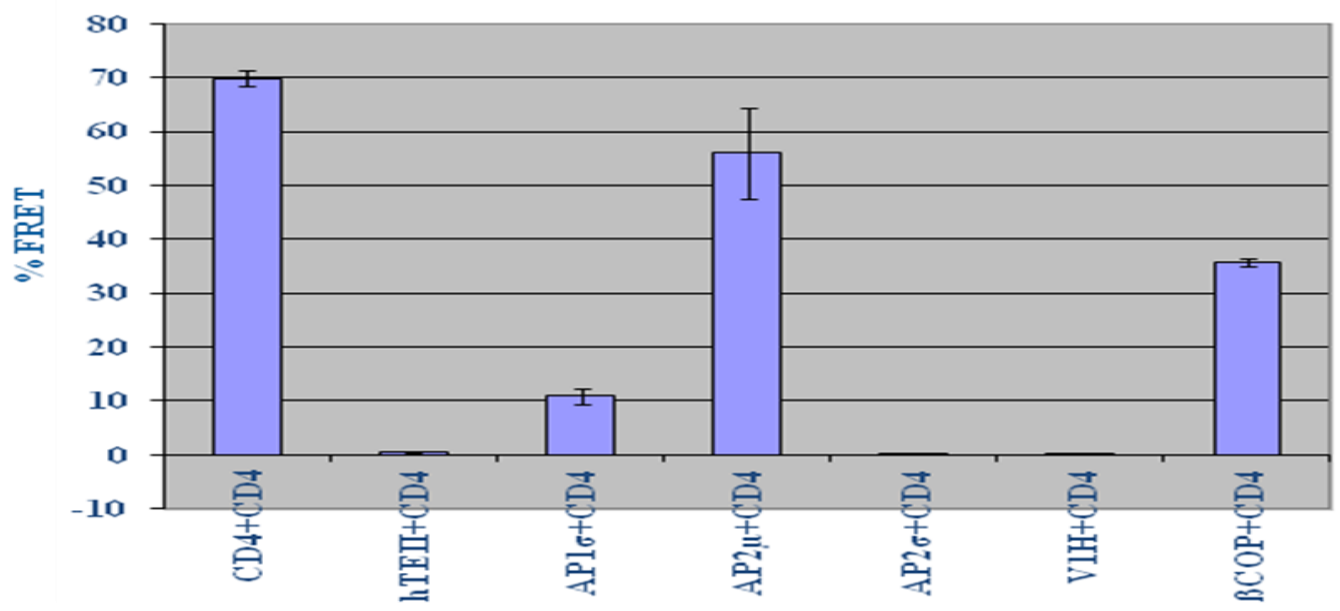

Figura 4.6. Níveis de interação direta entre as proteínas celulares e a proteína celular CD4 por \% de FRET. 48 horas após a transfecção em células 293T, com a proteína CD4 fusionada a YFP juntamente com as diferentes proteínas celulares fusionadas a CFP, incluindo CD4. Foram obtidos grandes níveis de interação entre a proteína CD4 fusionada a CFP e a proteína CD4 fusionada a YFP (75\%), por estarem sendo expressas no mesmo local e na concentração duas vezes maior que nos outros experimentos. A resposta quanto ao nível de interação da proteína AP2 $\mu$ com CD4 (50\%) confirmou a existência de uma necessidade de ligação entre essas duas proteínas celulares. $\beta \mathrm{COP}(33 \%)$ pareceu ter uma maior ligação com CD4 do que os alelos da proteína Nef.

A alta interação observada entre as moléculas de CD4 (70\%) pode obedecer a dimerização desta proteína na membrana plasmática o que levaria a um sinal de FRET, o qual não refletiria necessariamente uma interação fisiológica, pelo que constituiria um falso positivo. Como mencionado anteriormente, a proteína AP2 $\mu$ é uma das principais proteínas envolvidas na reciclagem endógena de CD4, o que ficou evidenciado pelos altos valores de FRET (50\%), confirmando a idéia que $\mathrm{AP} 2 \mu$ pode ser uma das proteínas mais importantes tanto na reciclagem como na modulação de CD4 mediada por Nef.

Outra proteína que mostrou níveis elevados de interação com o receptor CD4 foi a proteína $\beta$ COP (33\%), confirmando a participação desta na reciclagem fisiológica do receptor CD4, na formação e direcionamento de endossomos. Já a proteína AcoT8 não mostrou interagir com o receptor CD4, à diferença do observado com as variantes NL43 e NA7 do HIV-1. Este resultado sugere que na presença da proteína Nef do HIV-1, AcoT8 poderia ser recrutada para potencializar a modulação da molécula de CD4 dependente de Nef, ao menos em células humanas. Na literatura AcoT8 é descrita como uma enzima responsável por despalmitoilar a cauda transmembrânica da proteína CD4 para que esta seja sinalizada para reciclagem [235]. Entretanto, os resultados mostrados aqui sugerem que talvez esta proteína não interaja diretamente com a cauda transmembrânica do receptor CD4, proque tal vez necessite de algum tipo de sinalização prévia ou a participação de uma terceira proteína, para que a despalmitoilação da cauda citoplasmática do receptor de superfície CD4 aconteça. 
Apesar da proteína AP1 $\sigma$ ter mostrado um pequeno sinal de interação com CD4, este resultado não foi considerado significativo, o que se aplica também para as proteínas AP2 $\sigma$ e V1H que não mostraram nenhum tipo de interação direta com o receptor de superfície celular CD4.

É importante salientar a necessidade de repetir os experimentos acima descritos em presença dos alelos de Nef, com objetivo de verificar se os níveis de interação entre CD4 e as proteínas celulares sofrem alterações em presença da proteína viral.

Os resultados de interação por FRET entre as possíveis proteínas celulares parceiras de Nef e os três alelos da proteína viral encontram-se resumidos na Tabela 1 e expressos como porcentagem de interação entre as diferentes proteínas, tomando como referencia de $100 \%$ de sinal de FRET, células 293 T transfectadas com as proteínas repórteres fusionadas entre si, CFP fusionada a YFP, e como 0\% de sinal de FRET, células 293T co-transfectadas com vetores expressando as duas proteínas repórteres separadamente.

Como esperado, com base na literatura, foi possível constatar uma forte interação da proteína celular Ap2 $\mu$ tanto com a proteína celular CD4, como com os alelos Nef-NA7 e Mac239 (50,4; 45,1; 88,9 \%, respectivamente) [236], [237]. Contudo, os níveis de interação desta proteína celular com o alelo NL4.3 não se mostraram tão elevados quanto nos outros alelos (16\%), o que poderia evidenciar a necessidade da presença de outra(s) proteínas celulares, para que esta variante possa ter sua interação com CD4 potencializada. Estes resultados ressaltam a necessidade de repetir os ensaios na presença de outras proteínas celulares como a da própria molécula de CD4, o que poderia ser realizado utilizando linhas celulares de linfócitos $\mathrm{T}$ que expressem de maneira endógena todas as proteínas celulares, como por exemplo, a linha celular SupT-1, dessa forma todas as interações poderiam ser avaliadas num contexto mais próximo do "in vivo". Também foram registradas importantes interações entre a proteína $\beta$ COP com a proteína CD4 (33\%) e com Nef do alelo NA7 (30\%). No entanto, esta mesma proteína registrou uma interação relativamente fraca com a variante presente na cepa NL43 (12\%), resultado similar ao obtido com a proteína Ap2. Diferenças importantes nas sequências entre ambos os alelos, em outros sítios alem do domínio de ligação a $\beta C O P\left(E_{155}\right)$ [95], poderiam explicar estas diferenças de afinidade, tendo em vista [149], [150], [157], [95]. Estas semelhanças e diferenças, não somente na região de ligação das proteínas celulares nos alelos, de uma forma geral podem estar relacionadas a diferenças nos níveis de interação entre os alelos e as proteínas celulares.

Finalmente, é de interesse destacar a fraca interação da proteína celular V1H com todas as variantes de Nef e até com a proteína celular CD4 (3\%, 1\%, 0\% e 2\% respectivamente). Estes 
resultados viriam a confirmar dados da literatura no sentido que esta proteína cumpriria papeis subsidiários no processo de modulação de CD4 mediada por Nef, como por exemplo; aumentando a acidificação interna de endossomos, organelas vesiculares de eucariotos, entre outros [176], [177]. Por sua vez, a literatura também suportam estes resultados de baixa, ou nenhuma, interação entre estas proteínas, sendo que já foi descrito que a proteína V1H aumenta a força de ligação entre a proteína AP2 $\mu$ e CD4 [126], [125], [179]. Estes dados em geral vêm a reforçar a idéia de que mesmo alagumas proteínas celulares não tenham interação direta com os diferentes alelos da proteína Nef, elas podem ter um importante papel no processo e estar interagindo de forma indireta na degradação de CD4, mediada pela proteína Nef do HIV-1.

\begin{tabular}{|c|c|c|c|c|c|c|c|}
\cline { 2 - 8 } \multicolumn{1}{c|}{} & CD4 & AcoT8 & V1H & $\boldsymbol{\beta C O P}$ & Ap1 $\sigma$ & Ap2 $\boldsymbol{\mu}$ & Ap2 $\sigma$ \\
\hline CD4 & $75 \%$ & $2,10 \%$ & $1,50 \%$ & $32,85 \%$ & $16,15 \%$ & $50,40 \%$ & $0,45 \%$ \\
\hline Nef-NA7 & $38,55 \%$ & $89 \%$ & $3,20 \%$ & $30,20 \%$ & $15,10 \%$ & $45,15 \%$ & $0,80 \%$ \\
\hline Nef-239 & $13 \%$ & $0,25 \%$ & $0,55 \%$ & $5,00 \%$ & $1,90 \%$ & $88,95 \%$ & $0,05 \%$ \\
\hline Nef-NL4.3 & $21,55 \%$ & $63,9 \%$ & $0,15 \%$ & $12,15 \%$ & $2,8 \%$ & $15,95 \%$ & $0,15 \%$ \\
\hline
\end{tabular}

Tabela 4.1. Porcentagem de interações entre as proteínas celulares, os alelos de Nef e a proteína CD4, determinados por FRET. Células 293T foram co-tranfectadas com plasmídeos codificando CD4 ou os alelos; NA7, Mac239 e NL4.3 da proteína Nef fusionados a proteína repórter YFP e as diferentes proteínas celulares fusionadas a proteína repórter CFP, juntamente com os plasmídeos CFP fusionado a YFP, como controle positivo (100\% de FRET), e os plasmídeos codificando o gene CFP com plasmídeos codificando o gene YFP por separado, como controles negativos ( $0 \%$ de FRET), (dados não mostrados). Após 36 horas a frequência relativa de energia transferida (FRET) foi quantificada por citometria de fluxo. E a intensidade de energia transferida entre as proteínas foi calculada em porcentagem de interação entre elas.

Em resumo, a partir da interpretação dos resultados obtidos pela técnica de FRET podese fazer as seguintes considerações:

a) Há necessidade de repetir os ensaios para cada proteína na presença, se não de todos os outros possíveis parceiros de Nef, de pelo menos daqueles que participariam como co-fatores, aumentando ou diminuindo a interação entre uma dada proteína celular e Nef, em uma determinada etapa do mecanismo de degradação de CD4 em estudo. O mesmo conceito se aplica a avaliação das interações das proteínas celulares e o receptor CD4, sendo necessária a presença dos diferentes alelos de Nef. Isto nos permitiria não somente a analise da interação entre uma dada proteína com um dado alelo de Nef, mas também avaliar a possibilidade de interação das proteínas celulares entre si e seus efeitos. 
b) Há a importância de confirmar os resultados obtidos com células 293T, em linhas de células T como as; células Jurkat e SupT-1, células que expressam naturalmente a molécula CD4 e outras proteínas de membrana associadas, como as proteínas Hck e Lck, responsáveis por manter a conformação da porção N-terminal de CD4 e pela estabilidade da ligação de CD4 na membrana celular, respectivamente. Fatores estes importantes para ter uma real idéia da interação de cada proteína celular com Nef e a participação de cada proteína celular no mecanismo de modulação de CD4 por Nef.

\subsubsection{Identificação da interação de variatens humanas $e$ não humanas de Nef com as} proteínas celulares que apresentaram direta interação com Nef

Uma vez identificadas quais proteínas celulares têm de fato interação direta com a protein viral Nef, o próximo passo foi avaliar a conservação destas interações dentre os diferentes alelos de Nef encontrados nas diferentes cepas do vírus da Imunodeficiência presentes em primatas humanos e não humanos. Dessa forma os alelos de Nef presentes em HIV-1 (NA7, NL43, SF2) / SIVcpz (Tan3, NL4.3, NA7, Gab2, YBF30, 8161k9) / HIV-2 (BEN, CBL23) / SIVsm (FFm1) e SIV (Mac239, Syk51, AgmSab1, AgmTan1, FWr1) (Tabela 4.2) [223, 238] foram fusionados com o gene repórter EYFP e posteriormente os diferentes níveis de interação com as proteínas celulares; CD4, AcoT8, Ap2 $\mu$ ou $\beta$-Cop foram avaliados pela técnica de FACS-FRET.

\begin{tabular}{lcc}
\hline Linhagem & Clone & Espécie/ sub-espécie \\
HIV-1/M & NL4-3 & Human (Homo sapiens) \\
HIV-1/M & NA7 & Human (Homo sapiens) \\
HIV-1/N & YBF30 & Human (Homo sapiens) \\
HIV-1/O & MVP8161 & Human (Homo sapiens) \\
HIV-2 & BEN & Human (Homo sapiens) \\
HIV-2 & CBL-23 & Human (Homo sapiens) \\
SIVsmm & FWr1 & Sooty mangabey (Cercocebus atys) \\
SIVsmm & FFm1 & Sooty mangabey (Cercocebus atys) \\
SIVcpzPts & TAN3 & Eastern chimpanzee (Pan t. schweinfurthii) \\
SIVcpzPtt & GAB2 & Central chimpanzee (Pan t. troglodytes) \\
SIVsyk & KE51 & Sykes monkey (Cercopithecus albogularis) \\
SIVsab & 1 & Green monkey (Chlorocebus sabaeus) \\
SIVtan & 1 & Tantalus monkey (Chlorocebus tantalus) \\
SIVmac & 239 & Rhesus macaque (Maccaca mulatta)
\end{tabular}

Tabela 4.2. Relação dos alelos da proteína viral Nef previamente descritos serem moduladores dos receptores de superfície celular em PBMC e suas respectivas linhagens. Agrupamento filogenético de proteínas lentivirais Nef em HIV-1, HIV-2, SIVsmm, SIVcpz e outros SIVs. 
Nossos dados mostraram uma interação significativa de $\beta$-Cop com as proteínas de NefAgmSab1, AgmTan1, NL4.3, NA7 (15\%, 13\%, 10\% e 40\%, respectivamente) (Figura 4.10 A). Enquanto AcoT8 mostrou uma interação significativa apenas com os alelos NL4.3 e NA7 do HIV-1 (20\% e 62\% respectivamente) (Figura 4.10 B). Por outro lado, CD4 e Ap2 $\mu$ mostraram os maiores níveis de interação, embora variáveis com a maioria dos alelos da proteina viral Nef, tanto de primatas não humanos como humanos incluindo NL4.3 e NA7, onde mostraram interações $19 \%$ e $37 \%$ com CD4, enquanto que os mesmos alelos mostraram $10 \%$ e $27 \%$ de interação com Ap2 $\mu$ (Figura 4.10 C e D). A interação conservada entre a proteina viral Nef do HIV-1 com as proteínas celulares CD4, AcoT8, Ap2 $\mu$ e $\beta$-Cop sugere que estas proteínas provavelmente podem estar direta ou indiretamente envolvidas na modulação de CD4 induzida por Nef (Figura 4.7) [223].
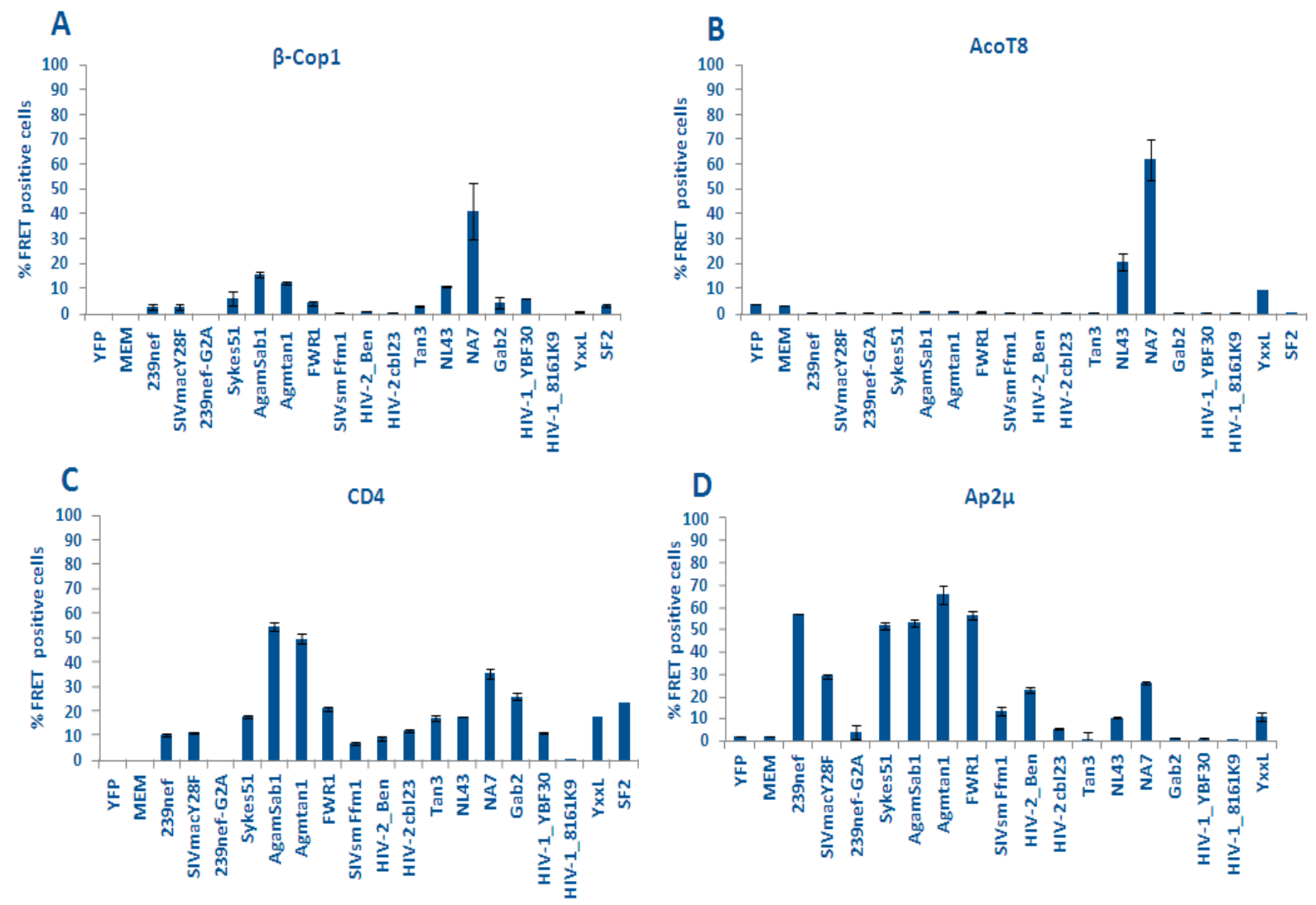

Figure 4.7. Interação das proteínas celulares com os diferentes alelos de Nef. Células Hek $293 \mathrm{~T}$ foram contransfectadas com diferentes alelos de Nef fusionados a EYFP (Nef-YFP) e as proteínas celulares $\beta$-Cop, AcoT8, CD4 ou AP2 $\mu$ fusionadas a CFP. 36 horas após a transfecção, as células transfectadas foram analisadas por FACS-FRET , como descrito anteriormente. (A) $\beta$-Cop-CFP mostrou uma interação significantiva apenas com HIV-1. (B) AcoT8-CFP mostrou uma interação significantiva com os alelos de Nef do HIV-1. (C) CD4 mostrou interação com todos alelos de Nef. (D) AP2 $\mu$-CFP, apesar de parcial em alguns casos, mostrou interação significativa com todos alelos de Nef.

Com objetivo de iniciar caracterização dos principais domínios da proteína Nef envolvidos na interaçãocom os factores celulares foram ralizados ensaios preliminares de 
FRET/FACS os que mostraram que a mutação G2A no domínio míristil de Nef seria crucial para promover interações de CD4, Ap2 $\mu$, e $\beta$-Cop com a proteína Nef do HIV-1 (dados não mostraos). Estes resultados podem ser explicados pela impossibilidade deste mutante para ser ancorar na membrana da célula [112].

Por outro lado, a interacção Nef-AcoT8, foi inibida nas mutantes del 17-26, PD112AA, e L110A-PD112AA (dados não mostraos) confirmando relatórios anteriores [231]. Espera-se que experimentos posteriors com um painel maior de mutantes nos permita identificar os domínios na proteína Nef envolvidos em cada uma das interações com as proteínas celulares descritas anteriormente.

\subsection{Análise de co-localização das proteínas celulares por microscopia confocal}

Posteriormente e com o objetivo de avaliar as consequências fisiológicas da interação das diferentes proteínas celulares com os alelos de Nef no que diz respeito à localização celular de cada proteína, foram realizados experimentos de microscopia confocal. Dessa forma células 293T foram co-transfectadas com vetores codificando as proteínas CD4, Nef-NA7 e Nef-Mac 239, fusionadas à proteína fluorescente YFP, conjuntamente com cada proteína celular de interesse, fusionadas à proteína fluorescente CFP. Os experimentos realizados com a variante NL43 da proteína Nef não foram incluídos por ter apresentado um excessivo "background" impossibilitando a captura da imagem, ajuste de intensidade, e consequentemente não permitindo uma correta interpretação dos resultados. Após 48 horas da transfecção, as células foram colhidas, lavadas com PBS+2\% SFB, fixadas com Mowiol e analisadas em ensaios de co-localização por microscopia confocal. As fluorescências expostas nas imagens (vermelho e azul) não são correspondentes às fluorescências dos genes repórteres fusionados às diferentes proteínas celulares (YFP e CFP), já que os canais utilizados para evidenciar as fluorescências foram escolhidos pelos níveis de nitidez que estes propiciavam na identificação da localização da expressão das proteínas estudadas.

\subsubsection{Caracterização da localização entre proteínas celulares e alelo Nef-NA7 por} microscopia confocal

Após analise dos experimentos de dupla marcação e localização, foi possível observar uma clara co-localização entre as proteínas celulares CD4, AcoT8, AP2 $\mu$ e $\beta C O P$ e o alelo NefNA7 (identificadas por setas), mas com certa variação na afinidade apresentada por cada proteína celular com o alelo, o que demonstrou mudança na localização de expressão da proteína AcoT8 quando na presença de Nef-NA7 (Figura 4.8). 
Os baixos níveis de expressão da proteína CD4, quando expressada simultaneamente com a Nef-NA7 em comparação aos níveis de expressão da proteína só, pode ser explicado pela modulação de CD4 por parte de Nef-NA7, mesmo fenômeno observado nos experimentos de FRET.

Os ensaios de localização realizados com a proteína AcoT8 mostraram claramente uma mudança no padrão de distribuição, após interação com o alelo Nef-NA7, passando de uma localização citoplasmática para uma de membrana (indicado por seta). A co-localizando com a proteína Nefconfirmou os grandes níveis de interação obtidos no experimento de FRET (Figura 4.3).

Em um nível bem mais baixo que o mostrado por AcoT8, entretanto a proteína AP2 $\mu$ também apresentou co-localização com o alelo NA7. No entanto, diferentemente de AcoT8, esta proteína não mostrou nenhum tipo de mudança de localização, ao menos perceptível, de expressão endógena na presença ou ausência do alelo NA7.

A proteína celular $\beta$ COP também co-localizou, mesmo que fracamente, com a proteína Nef-NA7. Este nível de interação também é observado nos ensaios de FACS/FRET, (Figura 4.3), entretanto o nível de interação entre esta proteína celular e o alelo não foi suficientemente elevado ao ponto de alterar a sua localização, como observado na figura 4.8.

Por outro lado, as proteínas celulares V1H e AP2 $\sigma$ não mostraram nenhuma mudança na presença ou ausência do alelo Nef-NA7. Esta ausência de co-localização vem confirmar o experimento da figura 4.3, onde, por FRET, estas proteínas não mostraram interagir diretamente com Nef-NA7. Este resultado reforça a idéia de que a proteína celular V1H, possa ter uma contribuição indireta para a modulação do receptor CD4, mediado por Nef. A proteína heterotetramérica AP2 subunidade $\sigma$, serviu como controle negativo, mostrando que a única subunidade que estaria envolvida diretamente na modulação de CD4 mediada por Nef, seria a proteína adaptadora 2 subunidade $\mu$. 

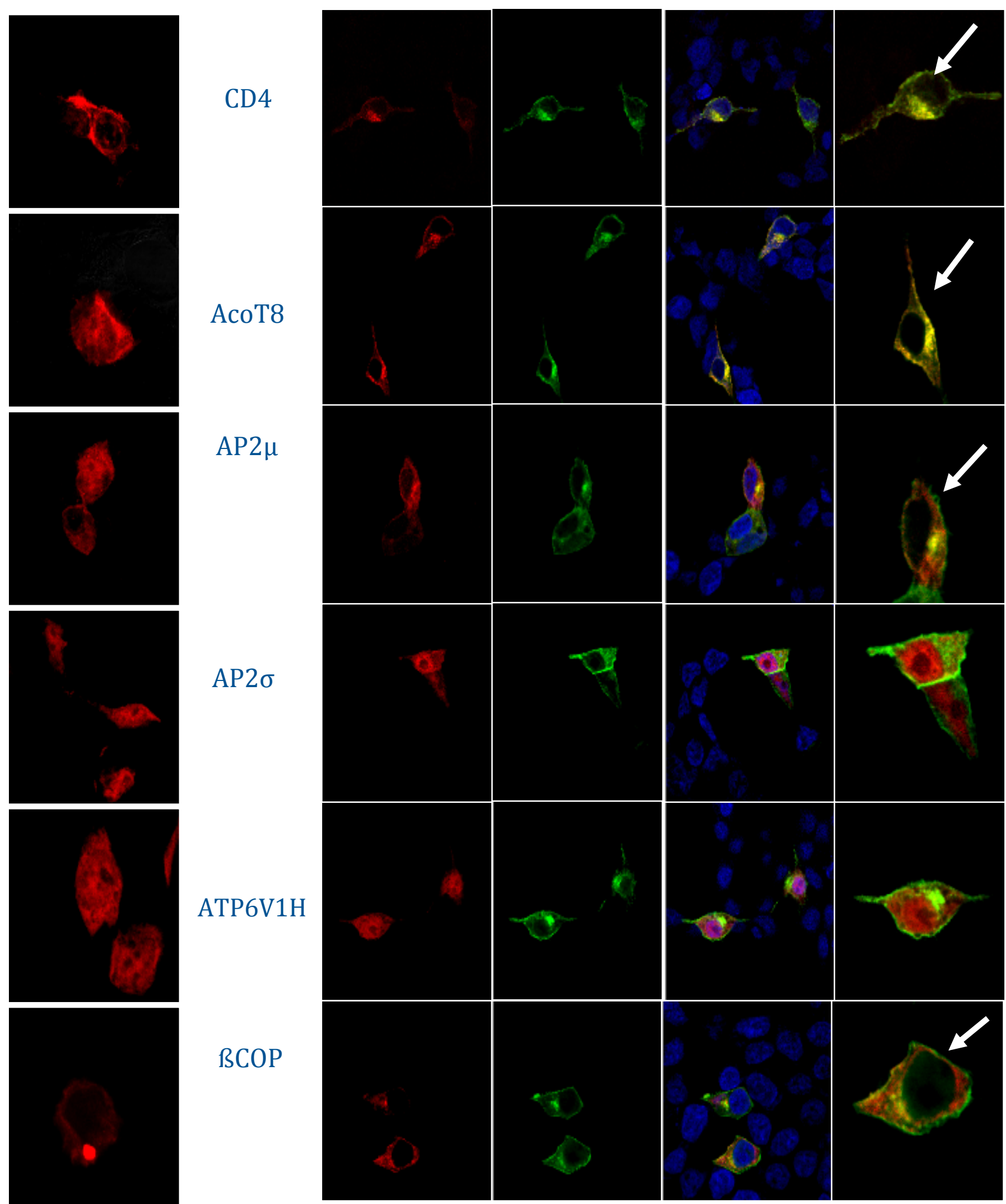

Figura 4.8. Caracterização da localização celular das proteínas celulares parceiras de Nef na presença da variante Nef-NA7 do HIV-1. Células $293 \mathrm{~T}$ foram co-transfectadas com vetores expressando as diferentes proteínas celulares fusionadas a proteína CFP conjuntamente com a proteína Nef-NA7 fusionada a YFP. Após 36 horas de transfecção as células foram fixadas com mowiol e analisadas por microscopia confocal. A figura mostra diferentes níveis de interações entre a proteína Nef-NA7 e as proteínas celulares CD4, AcoT8, AP2 $\mu$ e $\beta C O P$. 
Sendo que a proteína AcoT8 foi a única que mostrou uma mudança do lugar de expressão endógeno e passou a se concentrar mais nas regiões onde o alelo Nef NA7 era expresso.

\subsubsection{Caracterização da localização entre proteínas celulares e alelo Nef-NL4.3 por} microscopia confocal

Adicionalmente, foram avaliadoss os níveis de co-localização entre as proteínas celulares e o alelo da proteína viral Nef- NL4.3 do HIV-1. Como esperado, o alelo de NL4.3 mostrou uma co-localização com a proteina celular AcoT8, contudo em um nível menor quando comparado com o alelo NA7, também do HIV-1. Além disto, o alelo NL4.3 também colocalizou com as proteínas CD4 e $\beta$-Cop Ap2 $\mu$ resultando na translocação desta proteína, para a mesma região onde este alelo é expresso. Estes dados suportam os resultados quantitativos obtidos por FACS-FRET onde o alelo NL4.3 mostrou uma interação significativa com estas duas proteínas. 


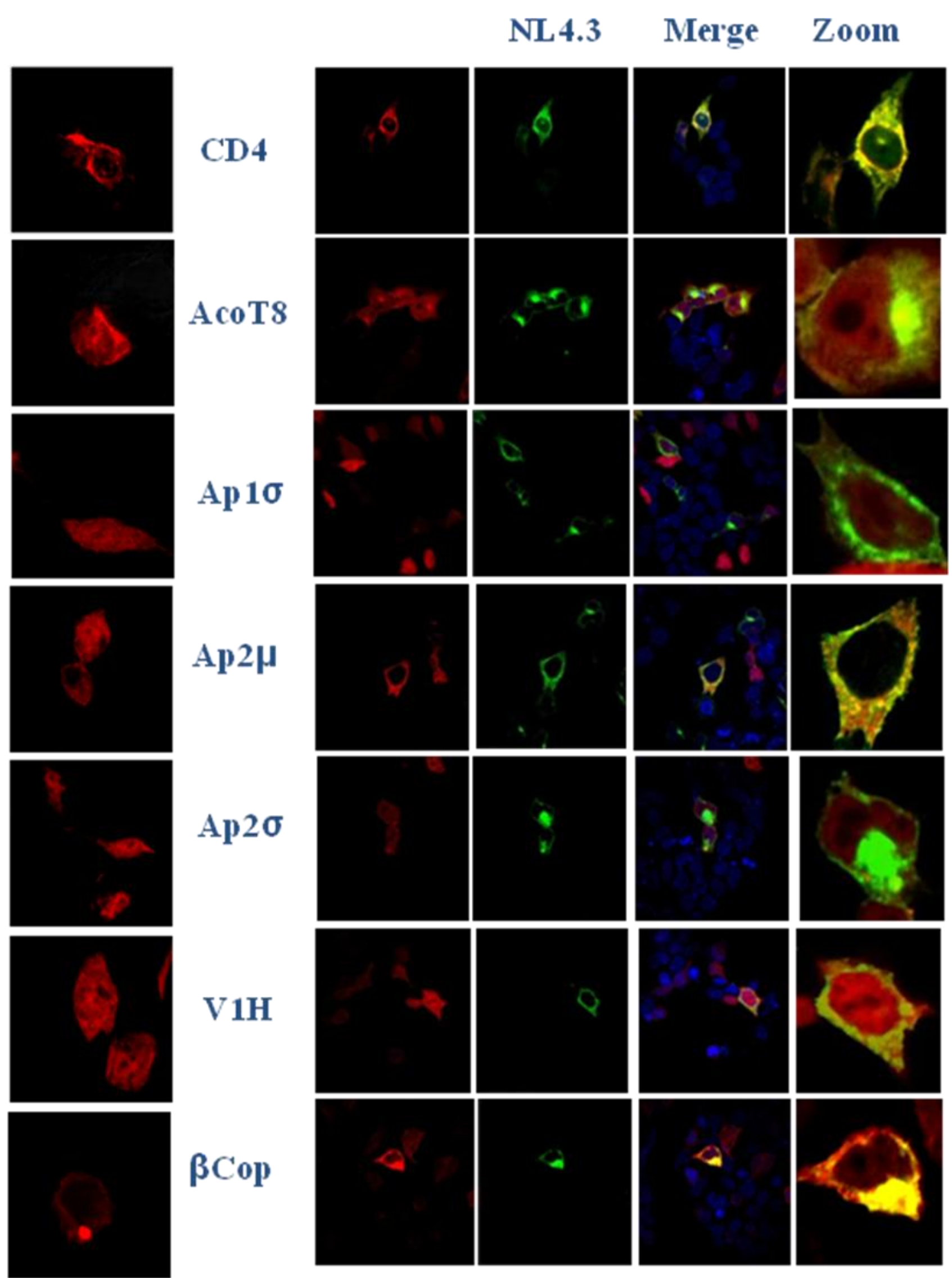

Figura 4.9. Caracterização da localização celular das proteínas celulares parceiras de Nef na presença da variante Nef-NL4.3 do HIV-1. Células Hek 293T foram co-tranfesctadas com vetores pECFP fusionados em cada uma das proteínas celulares, juntamente com o vetor pEYFP fusionado a proteína viral Nef alelo NL4.3 do HIV-1. 
36 horas após a transfecção as células foram analizadas por microscopia confocal, o que mostrou diferentes níveis de interação dentre as diferentes proteínas celulares.

\subsubsection{Caracterização da localização entre proteínas celulares e alelo Nef-Mac239 por} microscopia confocal

Os níveis de co-localização das proteínas celulares também foram avaliados em presença da versão de Nef presente em primatas não humanos, a cepa Mac239. Para isto foram co-transfectadas células $293 \mathrm{~T}$ com as diferentes proteínas celulares fusionadas à CFP, juntamente com o alelo de Nef-Mac239 de SIV (figura 4.10).

Diferentemente do alelo Nef-Na7 presente em humanos, o alelo presente em símios, Nef-Mac239, apresentou diferentes padrões de co-localização com as proteínas celulares.

Uma importante diferença, entre a co-localização do alelo NA7 com as proteínas celulares e a apresentada pelo alelo Mac239 com as mesmas proteínas, foi o nível de colocalização entre este alelo e a proteína AP2 $\mu$. Além desta proteína ter interagido em níveis mais altos com Nef-Mac239 do que com Nef-NA7, também mostrou ter uma alta afinidade com o Nef-Mac239, sofrendo mudança na localização intracelular do citoplasma para a membrana celular, região onde se localiza o alelo Mac239(vide setas da figura 4.10). Este fenômeno não foi observado com o alelo Nef-NA7. Resultados esses concordantes com os obtidos por FRET (figura 4.5).

Contudo, as outras proteínas celulares como; CD4, AcoT8, AP1 $\sigma$, AP2 $\sigma$, V1H e $\beta C O P$; não mostraram relevante co-localização com o alelo de Nef, Mac239, ao contrário de Nef-NA7 o qual mostrou co-localização principalmente com as proteínas CD4, AcoT8 e $\beta C O P$.

Por outro lado, a falta de co-localização entre CD4 e Mac239 pode ser atribuída a quase ausência da expressão do receptor CD4 na célula, já que é possível observar uma queda drástica no nível de expressão quando comparado com células transfectadas apenas com CD4 (controle). Este mesmo resultado, também é observado no ensaio da figura 4.5, o que vem reforçar a ideia de que a modulação de CD4, mediada por este alelo, é tão intensa que os níveis de expressão de CD4 diminuem por serem modulados rapidamente por este alelo.

Em resumo estes resultados mostram que os níveis de co-localização entre as proteínas celulares, envolvidas na modulação de CD4, mediada por Nef, e a proteína viral Nef é bastante variável, o que pode ser explicado pela diferença na sequência de aminoácidos entre os mesmos. 

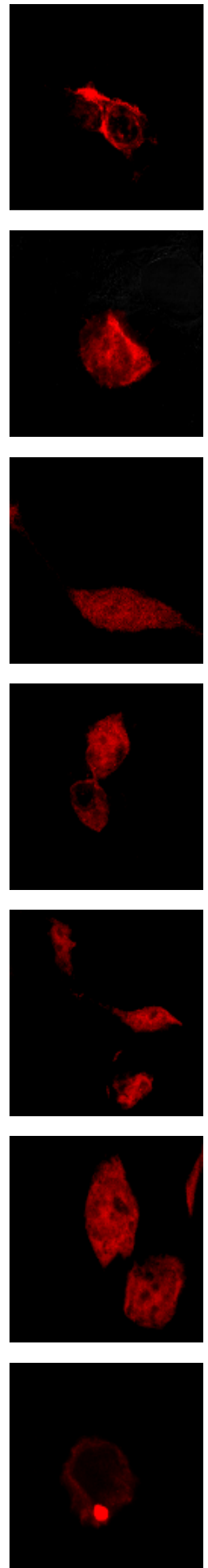

Figura 4.10. Caracterização da localização celular das proteínas celulares parceiras de Nef na presença da variante Nef-Mac239 de SIV. Células $293 \mathrm{~T}$ foram co-transfectadas com vetores expressando as diferentes proteínas celulares fusionadas a proteína CFP conjuntamente com a proteína Nef Mac239 fusionada a YFP. Após 
36 horas de transfecção as células foram fixadas com mowiol e analisadas por microscopia confocal. A proteína celular AP2 $\mu$ foi a única que mostrou interação com o alelo da proteína Nef, Mac239. Esta se mostrou com um nível de afinidade, com o alelo, tão alto que teve a localização endógena modificada para onde o alelo se concentrava.

\subsubsection{Caracterização da localização entre proteínas celulares e o receptor CD4 por}

\section{microscopia confocal}

Da mesma forma que nas analises por FRET foram avaliados os níveis de colocalização entre as proteínas celulares e o próprio receptor celular CD4. Para tanto, as diferentes proteínas celulares, fusionadas a proteína fluorescente CFP, foram transfectadas juntamente com a proteína celular CD4, fusionada a proteína fluorescente YFP, e analisadas por microscopia confocal (Figura 4.11).

De uma forma geral as proteínas celulares não aparentaram mudanças em suas localizações intracelulares. Entretanto, os altos níveis de interação entre moléculas de CD4, já observada nos ensaios de FRET, foram confirmados por microscopia confocal. Da mesma forma os resultados da co-localização entre as proteínas celulares AP2 $\mu$ e CD4 foram altos, igual que os níveis de interação mostrados por FRET.

Outra proteína que mesmo sem mudar sua localização endógena mostrou níveis de colocalização com o receptor CD4 foi a proteína celular $\beta C O P$. Da mesma maneira que AP2 $\mu$, esta proteína é expressa em toda região citoplasmática, sendo também expressa próxima a membrana celular interagindo com a molécula de CD4. No entanto, a proteína celular $\beta C O P$ não mostrou mudar sua localização endógena por interagir com a proteína CD4.

Já as proteínas AcoT8, Ap1 $\sigma$, AP2 $\sigma$ e V1H expressas também no citoplasma celuar como as proteínas $\mathrm{AP} 2 \mu$ e $\beta \mathrm{COP}$, não apresentaram nenhum tipo de co-localização com a proteína celular CD4. 


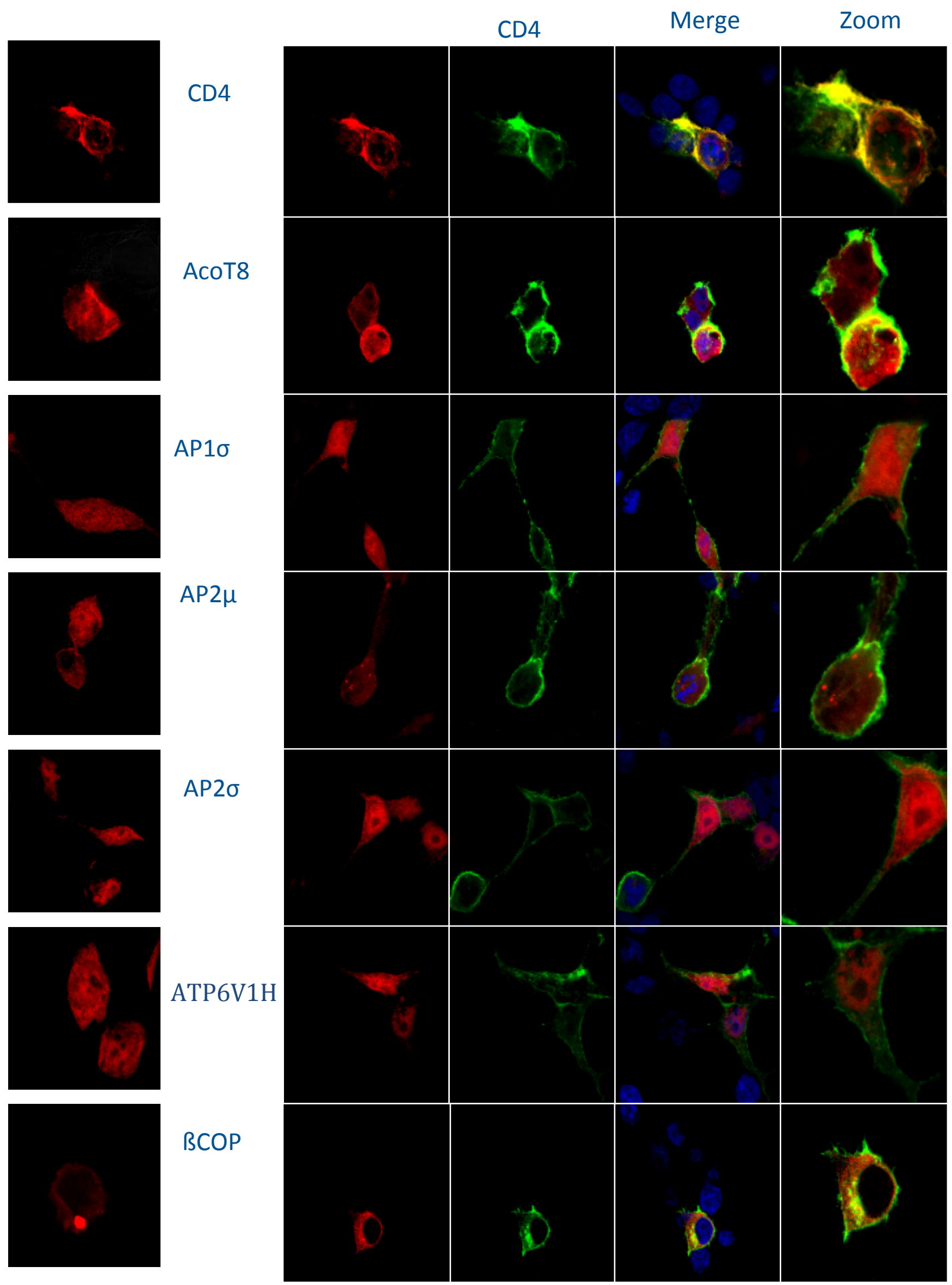

Figura 4.11. Caracterização da localização celular das proteínas celulares parceiras de Nef na presença do receptor de superfície celular CD4. Células 293T foram co-transfectadas com vetores expressando as diferentes proteínas celulares fusionadas a proteína CFP conjuntamente com o receptor celular CD4 fusionado a YFP. Após 36 horas de transfecção as células foram fixadas com mowiol e analisadas por microscopia confocal. As proteínas 
$\mathrm{CD} 4, \mathrm{AP} 2 \mu$ e $\beta \mathrm{COP}$, mostraram interagir com CD4. No entanto não foi observado nenhum tipo de mudança na localização endógena destas proteínas a fim de interagirem com a molécula de CD4.

Os resultados obtidos pela microscopia confocal encontram-se resumidos na tabela 2.

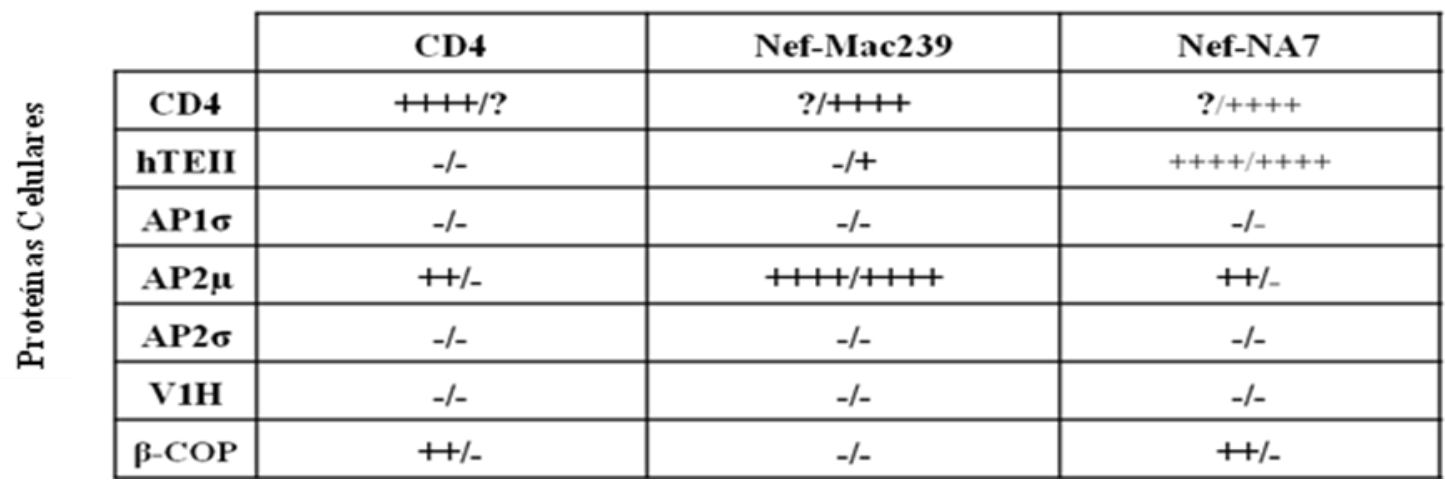

Tabela 4.3. Níveis de co-localização observados pela microscopia confocal. Na presente tabela encontram-se resumidos os resultados, com os níveis de co-localização, observados nos ensaios em microscopia confocal, entre as proteínas celulares e o receptor CD4, e os alelos de Nef (NA7 e Mac239). O sinal (+) indica a intensidade de colocalização, entre as proteínas; o sinal (-) indica ausência de co-localização; e o sinal (?) indica incerteza do nível de co-localização entre os alelos da proteína Nef (NA7 e Mac239) e o receptor CD4, dado os baixos níveis de expressão do receptor celular.

\subsection{Avaliação do bloqueio das proteínas celulares induzido por short hairpin RNA}

\subsubsection{Construção dos vetores codificando short hairpin RNA de interferência}

A confirmação da clonagem dos diferentes shRNA (vide materiais e métodos, figuras 3.2 e 3.3) foi obtida por digestão dos diferentes vetores lentivirais com as enzimas de restrição $X b a$ I e Cla I o que permitiu evidenciar a liberação de um fragmento de aproximadamente 300 pb correspondente às sequências que codificam o promotor H1 mais o shRNA (Figura 4.12).

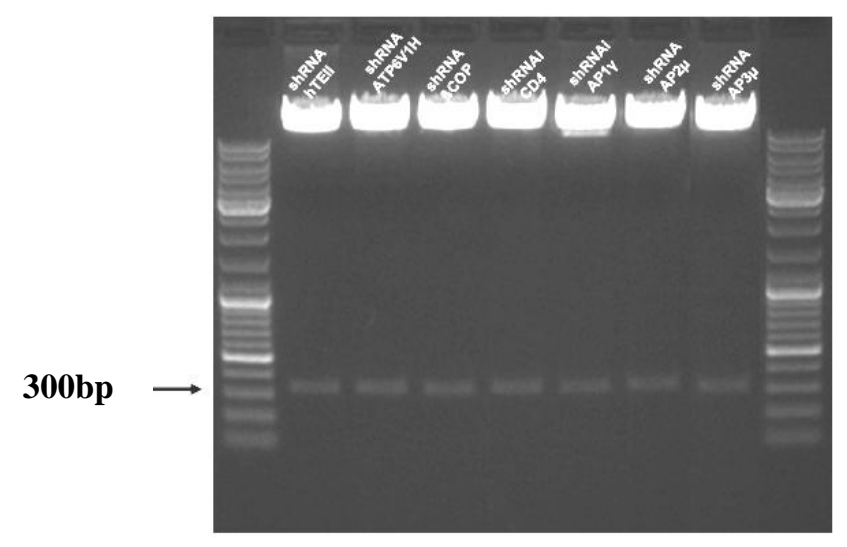

Figura 4.12. Confirmação da construção de vetores lentivirais codificando shRNA contra diferentes proteínas celulares. Os vetores lentivirais codificando os diferentes shRNAs e os genes EGFP-NEO foram obtidos em duas etapas. Brevemente, o cassete PGK-EGFP-NEO presente no vetor pSUPER, foi clonado no vetor lentiviral pNL-SIN utilizando as enzimas Xho I e BamH I. Finalmente os cassetes contendo os diferentes shRNAs sob o controle do promotor $\mathrm{H} 1$ previamente clonados no PSUPER foram clonados no vetor lentiviral pNL-SINPGK-EGFP-NEO utilizando-se as enzimas $C l a$ I e $X b a$ I, obtendo o vetor pNL-SIN-EGFP-NEO-shRNA. A clonagem dos diferentes shRNA foi confirmada por digestão com Xba I e Cla I, observando-se o fragmento de aproximadamente $300 \mathrm{pb}$, contendo as sequencias do promotor H1 e o correpondente shRNA. 


\subsubsection{Silenciamento exógeno das proteínas celulares}

Os níveis de inibição da expressão das diferentes proteínas celulares foram determinados por Citômetria de Fluxo, após co-transfecção de células 293T com os vetores codificando as diferentes proteínas celulares fusionados a proteína "repórter" CFP e o vetor lentiviral codificando o correspondente shRNA, ou alternativamente com o vetor lentiviral vazio.

A figura 4.13 mostra os resultados dos experimentos de inibição expressos como percentagem relativa, tomando como referencia de nível de expressão de $100 \%$ aqueles valores obtidos em células co-transfectadas com o vetor codificando a proteína de fusão e o vetor lentiviral vazio. Dessa forma foi possível observar uma forte inibição da expressão das proteínas celulares AcoT8, V1H, $\beta$-COP, Ap2 $\mu$ e CD4 (77\%, 78\%, 88\%, 99,05\%, 78\%,

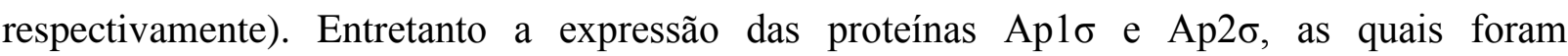
transfectadas juntamente com os vetores que codificam shRNA para AP1Y e Ap2 $\mu$ respectivamente, não foram bloqueadas, demonstrando a especificidade dos shRNA utilizados (dados não mostrados).

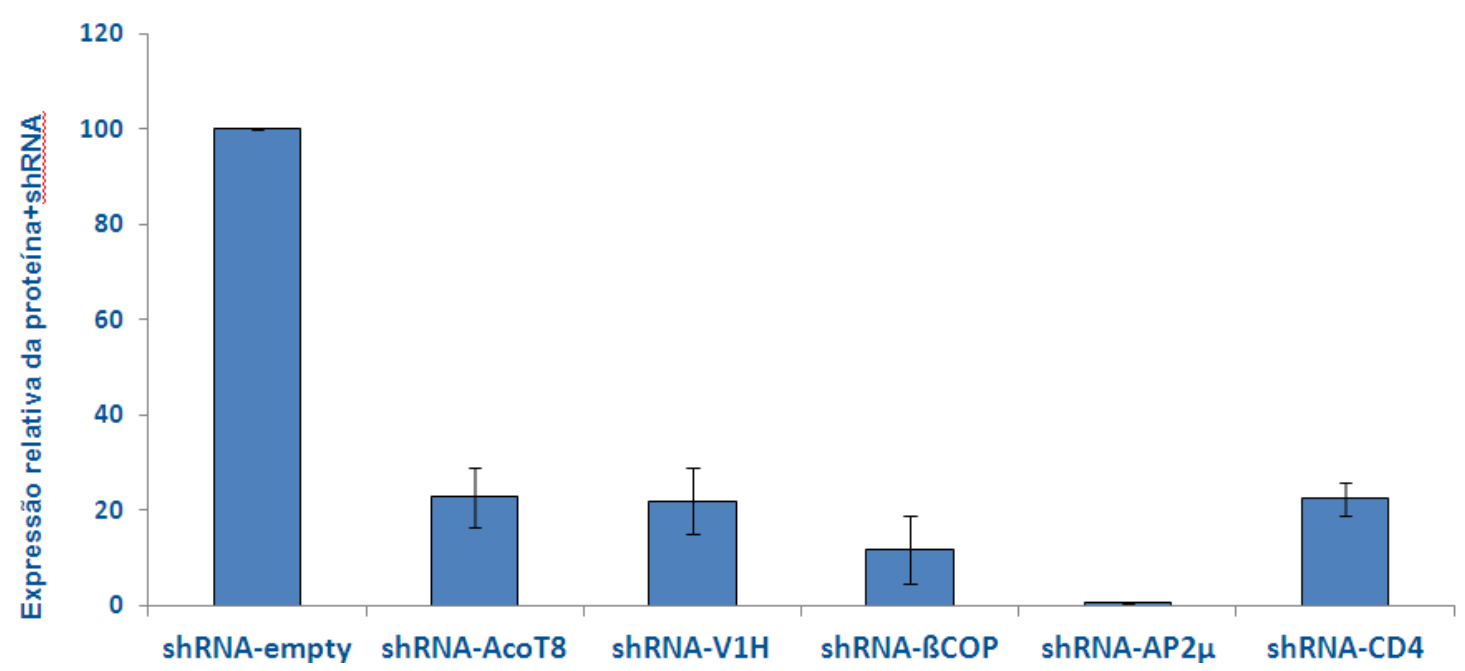

Figura 4.13. Bloqueio da expressão de proteínas celulares fusionadas a CFP mediante o uso de shRNA. Células 293T foram transfectadas com vetores codificando as diferentes proteínas celulares de interesse fusionadas a proteína fluorescente CFP ou conjuntamente com os vetores lentivirais expressando RNai específicos para cada proteína, assim como não específicos. 48horas após a transfecção a intensidade de fluorescência CFP foi determinada por Citômetria de Fluxo.

\subsection{Produção de partículas virais, infecção e superinfecção}

\subsubsection{Quantificação de p24}

48hs após co-transfecção de células 293 T com os vetores lentivirais codificando os diferentes shRNA juntamente com os vetores necessários para a expressão de proteínas virais envolvidas no empacotamento (pCMV $\Delta$ R8.9) e a glicoproteína do envelope do vírus da estomatite vesicular VSVg (pMDG), aproximadamente $1 \mathrm{ml}$ dos sobrenadantes celular foram 
recolhidos, e deste estoque $10 \mu \mathrm{l}$ foram utilizados para quantificação das partículas virais por ELISA.

Foi utilizado como controle positivo o vetor expressando a sequência do vírus HIV, cepa NL4.3, do tipo selvagem - "wild type”, o qual mostrou uma alta concentração da proteína p24 (proteína que constitui o nucleocapsídeo viral) no sobrenadante, o que indica a presença de partículas virais. Utilizando este primeiro resultado como parâmetro, foi possível observar que o nível de p24 obtido no sobrenadante de todos os outros lentivirus transfectados alcançou níveis significativos (dados não mostrados).

\subsubsection{Silenciamento endógeno das proteínas celulares}

Com objetivo de avaliar a inibição da expressão endógena das proteínas celular por meio dos vetores lentivirais, células da linha de linfócito T (SupT-1) foram transduzidas com partículas virais expressando os diferentes shRNA. A eficiência da transdução foi avaliada por microscopia de fluorescência 120 hs após a transdução e posteriormente as células GFP positivas que apresentaram a maior expressão foram separadas das GFP negativas por meio de "sorting" realizado em um aparelho de Citômetria de Fluxo FACS ARIA. Finalmente a expressão das diferentes proteínas celulares foi avaliada no lisado celular por meio de “imunobloting” usando anticorpos específicos (Figura 4.14). Dessa forma foi possível observar altos níveis de inibição da expressão das diferentes proteínas celulares na presença de seus respectivos shRNAs, confirmando a eficiência dos vetores lentivirais no bloqueio da expressão das diferentes proteínas celulares (Figura 4.14).

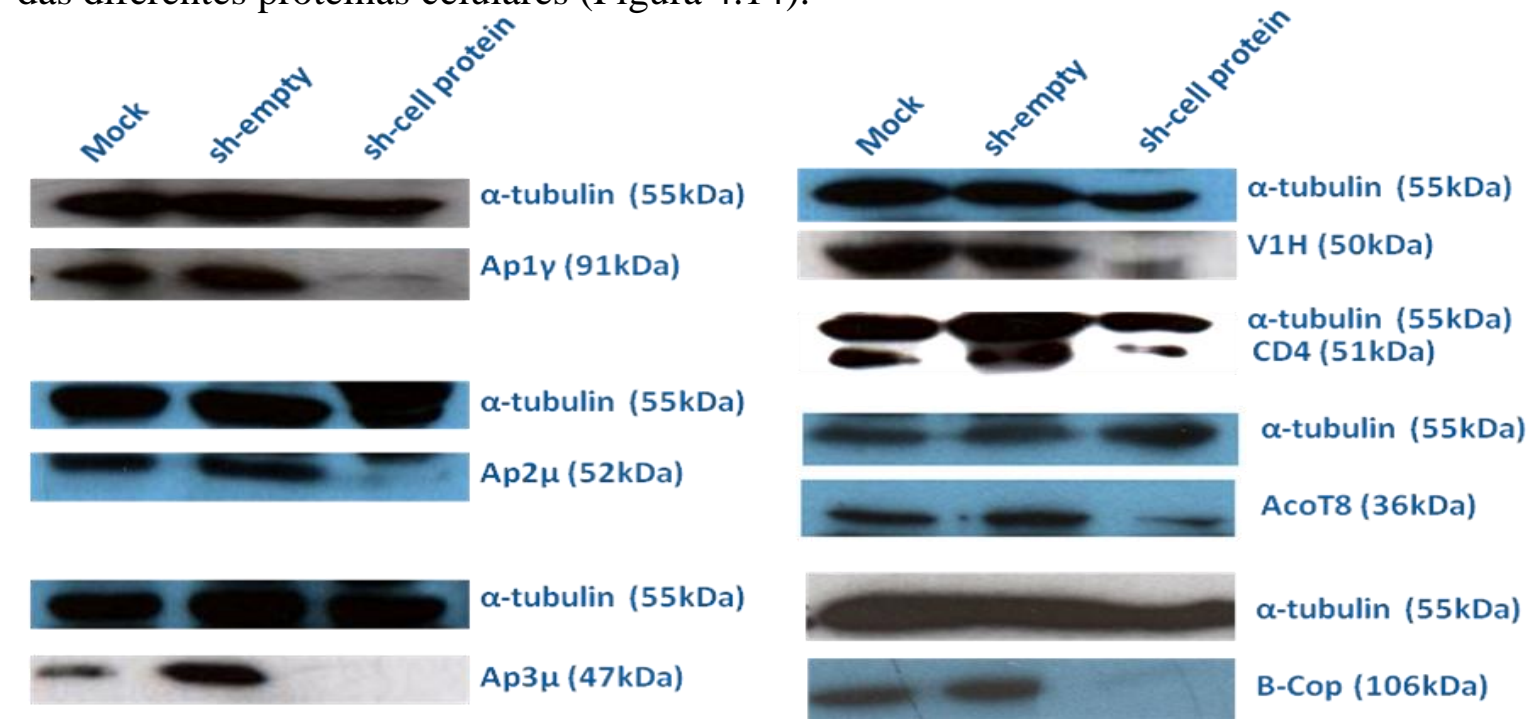

Figura 4.14. Inibição da expressão endógena por shRNA de proteínas celulares envolvidas na modualção de CD4 mediada por Nef. O bloqueio da expressão endógena das proteínas CD4, Ap1 $\gamma$, Ap $2 \mu$, Ap3 $\mu, \beta-C O P$, V1H e AcoT8, pelos diferentes shRNA foi confirmada por immunobloting de lisados provenientes de células SupT-1, transduzidas com os diferentes vetores lentivirais, usando anticorpos específicos. 


\subsubsection{Relevância fisiológica de proteínas celulares na modulação do receptor CD4}

mediada por Nef

Num primeiro momento foi avaliada a participação das proteínas celulares na reciclagem da molécula CD4 em condições fisiológicas. Para isto células da linha de células T Jurkat E6.1 foram transduzidas com os sobrenadantes das células 293T, recolhidos nos experimentos anteriores, contendo partículas virais codificando shRNAs contra cada uma das proteínas celulares em estudo ou apenas codificando a proteína repórter GFP. Quatro dias após a transdução, as células viáveis foram recuperadas e os níveis de expressão de CD4 foram determinados usando anticorpo especifico anti-CD4-APC (florescência azul) e a média de intensidade de fluorescência (Mean Fluorescence Intensity - MFI) de CD4, foi determinado por FACS, apenas naquelas células transduzidas GFP positivas. Os valores de MFI-APC-CD4 obtidos de três experimentos independentes foram graficados em percentagem, considerando $100 \%$ a media de valores de APC-CD4 obtidos em células Jurkat E6.1 transduzidas com o vetor lentiviral codificando apenas a proteína GFP (Figura 4.15).

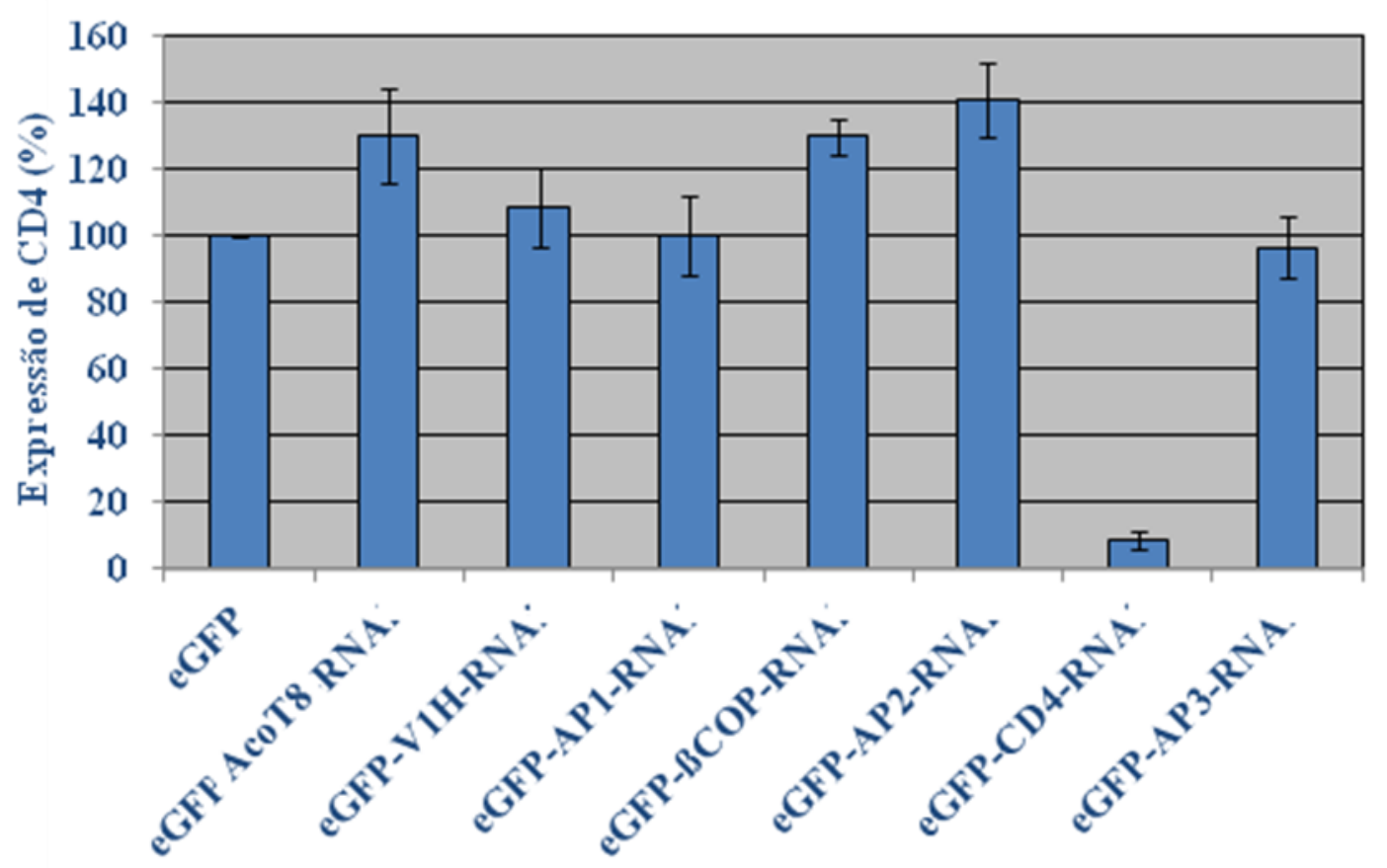

Figura 4.15. Níveis de expressão do receptor CD4 em células Jurkat E6.1 transduzidas com vetores letivirais expressando shRNA. Células Jurkat E6.1 foram transduzidas com partículas virais expressando shRNA para as diferentes proteínas celulares e após 96 horas, os níveis de CD4 foram determinados usando anticorpo especifico (anti-CD4-APC), a media dos valores obtidos de três experimentos independentes foram graficados em percentagem, considerando 100\% a media de valores de CD4 obtidos em Jurkat E6.1 transduzidas com o vetor lentiviral codificando apenas a proteína GFP. 
O bloqueio da expressão das proteínas AcoT8, AP2 $\mu$ e $\beta$-COP levou a um aumento da expressão de CD4 (30\%, 41\% e 30\%, respectivamente) quando comparado ao apresentado pelo controle, mostrando claramente a participação destas proteínas no processo de internalização fisiológica da molécula CD4. Estes resultados vieram a confirmar resultados anteriores obtidos por nosso grupo em células 293T, quanto ao aumento de até $60 \%$ na expressão de CD4 na presença do shRNA para AcoT8 [193]. Já os níveis de expressão de CD4 não foram alterados em células transduzidas com vetores expressando shRNAs para as proteínas AP1 $\gamma$, V1H, e $\mathrm{AP} 3 \mu$. É importante salientar a existência de uma grande discrepância na literatura quanto a participação destas proteinas $[95,127,145,175,186,223,239,240]$. Finalmente os níveis de expressão de CD4 foram diminuídos drasticamente em células transduzidas com vetores expressando shRNA específico para este receptor (controle positivo).

Entretanto em experimentos posteriores não foi possível avaliar o impacto do bloqueio na expressão destas proteínas no contexto da infecção pelo HIV, uma vez que estas células não apresentaram um período de viabilidade suficiente para serem co-transduzidas com partículas virais carregando Nef WT ou Nef truncado (dados não mostrados).

Dadas as limitações apresentadas por esta linha celular a elucidação da participação das diferentes proteínas celulares tanto na reciclagem endógena-fisiologica, assim como a modulação de CD4 mediada pela proteína Nef foram realizados em células SupT-1, uma outra linha de células $\mathrm{T}$ com maior resistência as condições experimentais.

Sendo assim, células SupT-1 foram transduzidas com partículas virais carregando shRNA para cada um dos fatores celulares, contudo os nivieis de expressão de CD4 não mostraram variações significativas na expressão de CD4 na superfície celular, ao contrário ao apresentado pelas Jurkat E6.1 (Figura 4.16). 


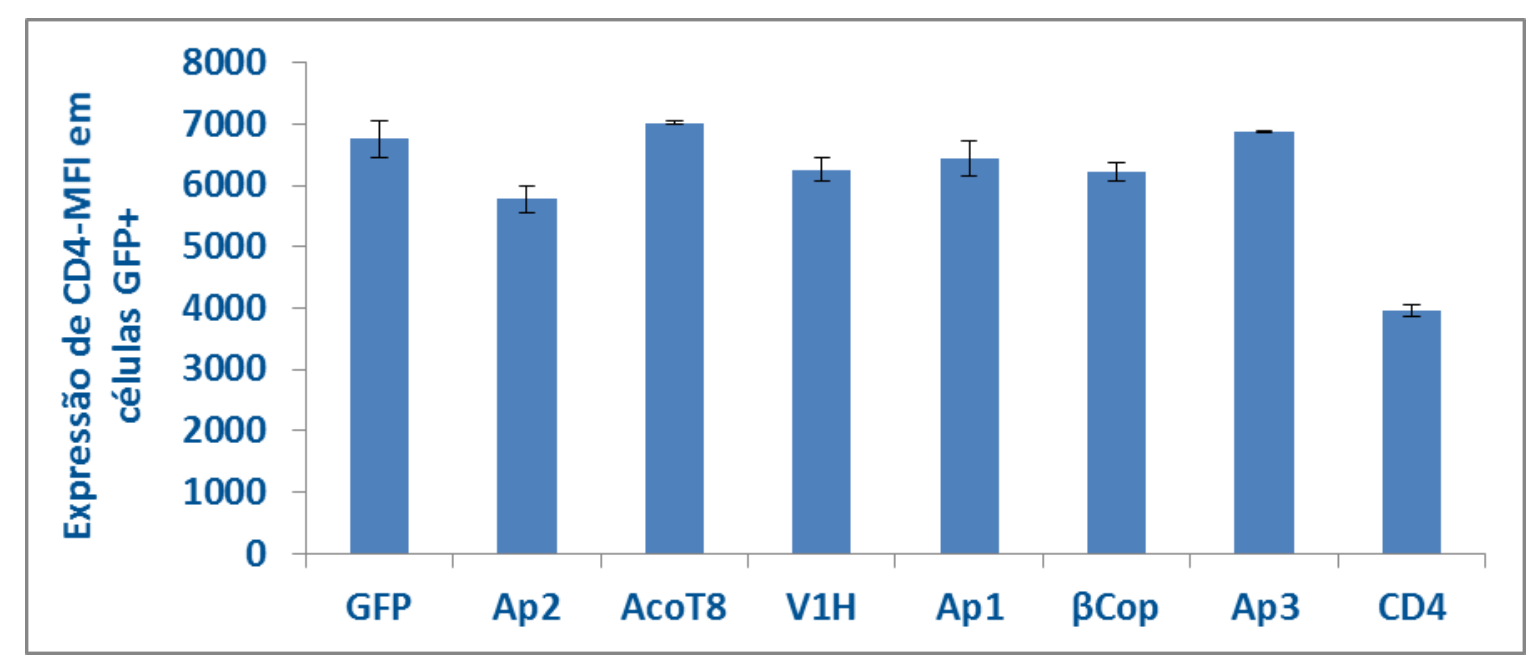

Figura 4.16. Niveis de expressão de CD4 na presença de shRNAs contra diferentes proteínas celulares. Células SupT-1 foram transduzidas com partículas lentivirais pseudotipadas carregando shRNA para as proteínas celulares. Após 5 dias de incubação, os níveis de expressão das proteínas foram determinados por FACS utilizando anticorpos específicos ant-CD4(APC).

Estes resultados podem ser explicados pelos elevados níveis de expressão de CD4 apresentados por estas células quando comparados aos apresentados por outras linhas de células T como as Jurkat e até linfócitos de sangue periférico (Figura 4.17). Os elevados níveis de expressão destas células poderiam mascarar variações na expressão do receptor CD4 impedindo a avaliação da participação fisiológica destes fatores celulares na expressão de CD4 na superfície celular.

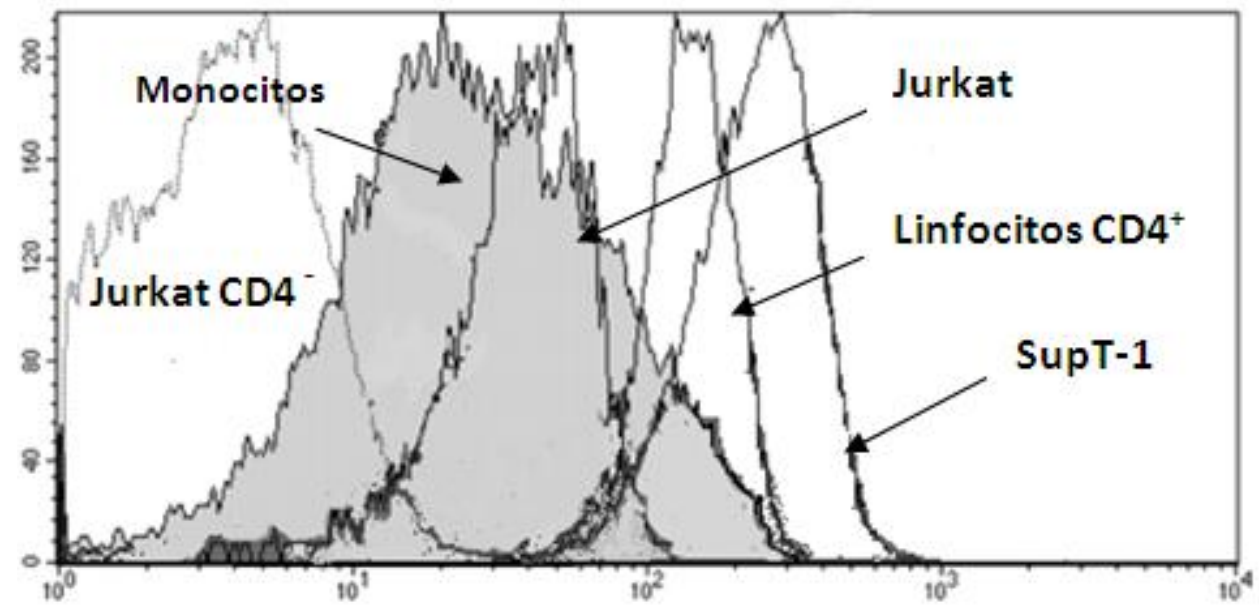

Figura 4.17. Nivies de expressão do receptor CD4 em diferentes linhas de celulas T e linfocitos de sangue periferico. A expressão dos níveis de CD4 na superfície celular das diferentes linhagens e linfócitos de sangue periférico foi determinado por FACS utilizando anticorpo fluorescente especifico para CD4-PE. Os "settings" foram ajustados para corrigir os tamanhos dos diferentes tipos celulares. Todos os tipos celulares mostraram similares níveis de "background" de fluorescência quando usado o anticorpo isotipico controle. Os valores de fluorescência foram obtidos de um simple experimento realizado em paralelo. Os valores médios de fluoescencia foram: Jurkat-T No-CD4 (4), Jurkat-T-CD4 (28),monocytes (39), PBLs (143), and SupT1 (232).

Levando em consideração que estas células também expressam o Complexo Principal de Histocompatibilidade Classe I (MHC-I) em níveis menores aos de CD4 e que esta moelcula 
também é modulada por Nef [241 102, 242 103], o papel desses fatores celulares na reciclagem fisiológica deste outro receptor também foi avalaido. Em contraste a CD4, observamos um claro aumento nos níveis de expressão de MHC-I na apresença dos shRNAs contra cada uma das proteínas celulares. Os maiores níveis de expressão do receptor foram observados na presença dos shRNAs contra as proteínas Ap2 $\mu$, AcoT8, V1H, Ap1 $\gamma$ e $\beta C O P$ (Figura 4.18), sugerindo um relevante envolvimento destes fatores no processo de reciclagem do MHC-I em concordância com a literatura [120, 137, 146, 241-245].

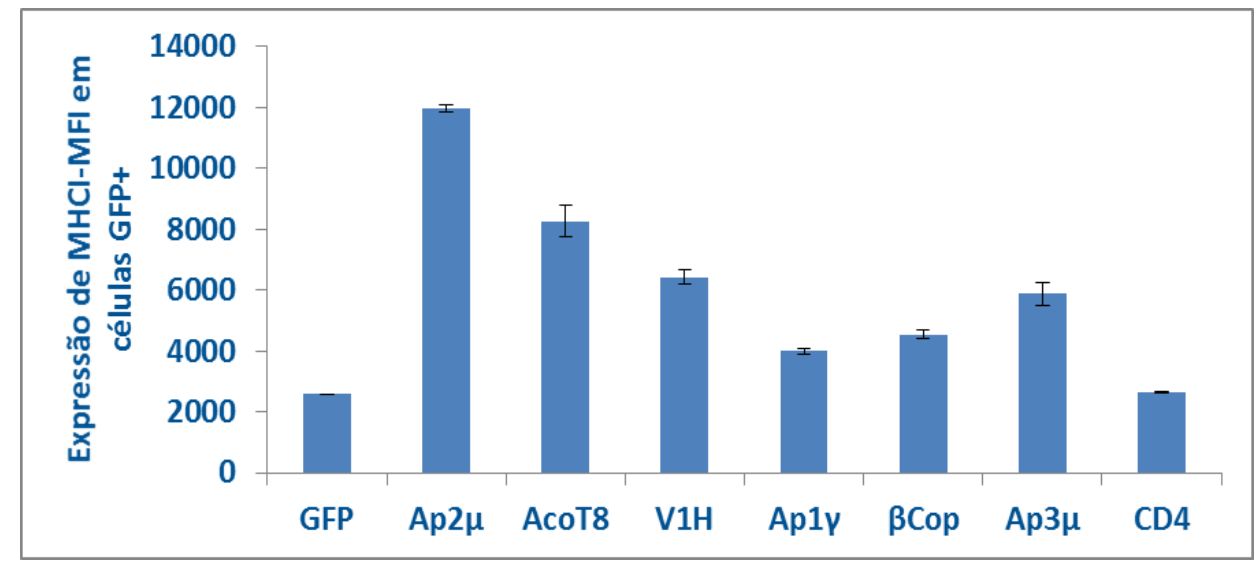

Figura 4.18. Niveis de expressão de MHC-I na presença de shRNAs contra diferentes proteínas celulares. Células SupT-1 foram transduzidas com partículas lentivirais pseudotipadas carregando shRNA para as proteínas celulares. Após 5 dias de incubação, os níveis de expressão das proteínas foram determinados por FACS utilizando anticorpos específicos ant-MHC-I(PE)

Com o objetivo de avaliar a relevância fisiológica da depleção das diferentes proteínas celulares na modulação de CD4 mediada por Nef no contexto da infecção viral, células SupT-1 foram transduzidas com partículas lentivirais pseudotipadas codificando os shRNAs específicos para cada proteína celular. Após 5 dias de incubação as células foram co-transduzidas com partículas lentivirais pseudotipadas codificando o provirus da cepa NL4.3 do HIV-1 (Nef "wild type" ou Nef deficiente), onde os genes que codificam as proteínas Vpu e Env, as quais também participam na degradação intracelular de CD4, foram deletados para evitar qualquer viés na interpretação dos resultados. Após incubação por 72h, os níveis de expressão de CD4 e MHC-I foram determinados por FACS usando anticorpos específicos anti-CD4(APC) e anti-MHC$\mathrm{I}(\mathrm{PE})$.

Com o propósito de analisar a degradação destas duas proteínas mediada exclusivamente por Nef e no contexto da inibição de expressão de cada parceiro celular, por seu correspondente shRNA, células duplamente transduzidas foram selecionadas pela dupla expressão das fluorescências GFP e BFP, correspondentes a expressão dos vetores lentivirais, pNL-shRNA e pBR-Nef respectivamente, e os níveis de expressão das proteínas de superfície CD4 e MHC-I 
foram determinados pela marcação com anticorpos fluorescentes específicos. A partir do valor de MFI presente no grupo duplo positivo, a modulação dos receptores celulares foi avaliada tendo como base de cálculo $\mathrm{NEF}^{\mathrm{N}} / \mathrm{NEF}$ - na presença de cada um dos diferentes shRNAs. Por exemplo, na inibição do fator celular Ap2 a expressão de CD4 na superfície celular foi calculada dividindo o valor de MFI obtido na presença do vírus selvagem "wild type", $\left(\mathrm{Nef}^{+} / \mathrm{Vpu}^{-} / \mathrm{Env}^{-}\right)$, pelo valor de MFI obtido na presença de vírus defetivos na proteína Nef (Nef $\left./ \mathrm{Vpu}^{\top} / \mathrm{Env}^{-}\right)$. As médias dos valores correspondentes a 3 "sets" de experimentos $(\mathrm{n}=9)$, foram plotados em gráfico analítico proveniente da análise do "software" Graph Pad Prism 6 (Figura 4.19 A e B).
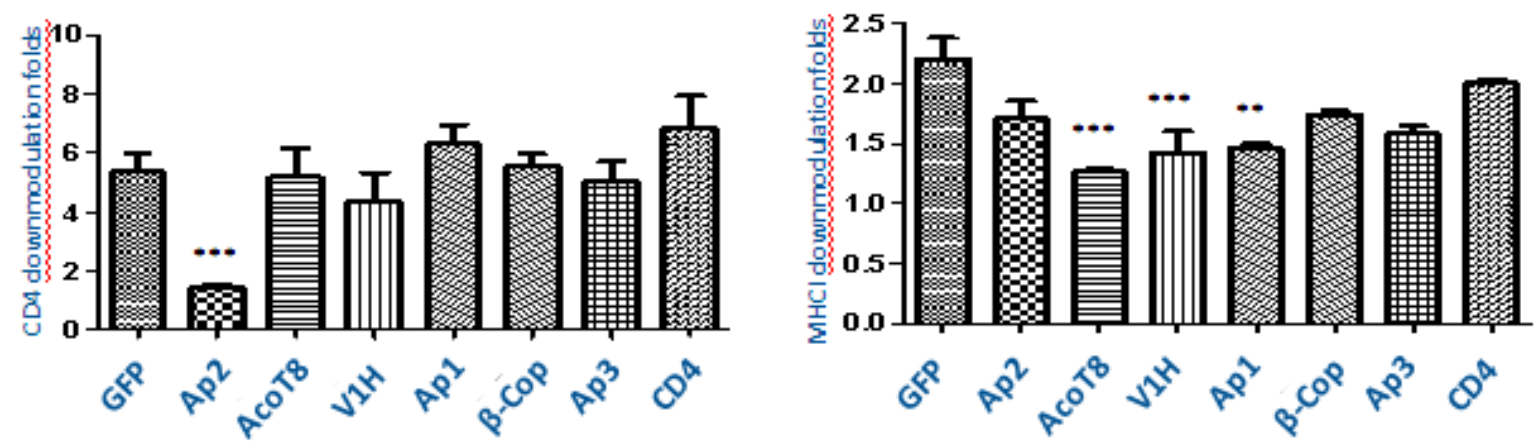

Figura 4.19. Modulação de CD4 e MHC-I pela proteína Nef em células transduzidas com shRNAs para diferentes proteínas celulares. Os níveis da modulação de CD4 e MHC-I mediado por Nef, foram determinados em células SupT-1 transduzidas com partículas lentivirais pseudotipadas carregando shRNA para as proteínas celulares e com a proteína viral Nef, células duplo positivas (vide desenho experimental e metodologia) Aquisição e análise obtidas por Citometria de Fluxo.

Após o "Knock-down" das proteínas celulares em células SupT-1 a modulação do receptor CD4 mediada por Nef foi fortemente afetada em presença do shRNA contra a proteína celular Ap2, uma vez que a degradação do receptor celular foi inibida em aproximadamente cinco vezes quando comparado aos níveis de degrdação do controle negativo, células transduzidas com partículas virais não codificando nenhum shRNA (figura 4.19 A). Estes resultados apontaram à proteína Ap2 com o principal fator celular envolvido na modulação de CD4 mediada por Nef. A relevância AP2 na modulação CD4 foi previamente relatada por Wolf Lindwasser e colaboradores, e outros, [78, 243, 246]. Por outro lado foi possível observar uma modesta diminuição da modulação de CD4 em presença do shRNA contra a proteína V1H, entretanto esta diminuição não atingiu significância estatística. Este ultimo resultado vem ao encontro de resultados prévios relacionados a participação desta proteina celular no aumento da eficiência de ligação Nef-Ap2[78, 126, 239].

Já a ausência de qualquer efeito no mecanismo de degradação de CD4 quanto da diminuição da expressão das proteínas $\beta$-COP e AcoT8, se contrapõe a resultados prévios da literatura [129, 149]. Entretanto é importante salientar que estas discrepâncias têm sido cada 
vez mais frequentes na literatura $[165,247]$. O papel de $\beta$-COP no transporte endosomal normal ou dependente de Nef não é bem entendido. Existem evidencias que o trafego endosomal de CD4 Nef dependente envolve o motivo com dois ácidos glutâmicos [188, 227]. Por outro lado as proteínas $\beta$-COP, ARF1 e Nef foram co-imunoprecipitadas em células Hela, onde estas proteínas foram overexpressas [188]. Entretanto em outros estudos não foram observados estes resultados [145] o que realça na necessidade de maiores estudos para elucidar o real papel desta proteína na modulação de CD4 mediada por Nef.

Outro exemplo são os resultados obtidos por Rose e colaboradores, onde por meio do uso da técnica de RNAi contra a proteína Ap2, não observaram nenhum efeito na modulação de CD4 mediada por Nef, ainda que tenha afetado a modulação de CD4 mediada por Nef de SIV, assim como bloqueado a internalização do receptor de transferrina [248]. Em contraposição, outros dois estudos, ao igual que o nosso, reportaram que a proteína Ap2 seria um fator importante na degradação de CD4 [136, 249], ainda que em um deles tenha observado que a dependência de Ap2 era observada só na presença da proteína Eps-15 [136].

Estes dados vem a reforçar a necessidade de padronização quanto ao uso de linhas celulares e alelos de Nef, assim como a utilização de abordagens onde sejam avaliados o papel das diferentes proteínas celulares em conjunto, permitindo uma maior aproximação das condições fisiológicas da acorrencia deste mecanismo “in vivo” [247].

Já o impacto do "Knock-down" destas proteínas celulares, na modulação de MHC-I mediado por Nef nos possibilitou confirmar dados da literatura como os reportados por Roeth et al, 2004, a respeito do envolvimento de AP1 no processo de modulação da proteína de superfície celular MHC-I [243, 247]. Além disto, AcoT8 também mostrou ter um impacto significantivo na modulação de MHC-I mediada por Nef, como descrito por Liu et al, 2000 [231]. Curiosamente, a proteína celular V1H também mostrou ser importante fator neste mecanismo, uma vez que até o momento não há informações na literatura sobre a participação desta proteína celular na degradação de MHC-I (Figura 4.19 B). A princípio estes resultados sugerem fortemente que estes fatores celulares estão envolvidos na reciclagem endógena de MHC-I e abrem novas perspectivas para o estudo de novas proteínas, ate agora não estudas e que podriam ter um papel importante neste mecanismo.

Finalmente com o objetivo de verificar a relevância fisiológica destas proteínas celulares em condições mais próximas à infecção "in vivo", linfócitos $\mathrm{CD}^{+}\left(\mathrm{LT}-\mathrm{CD} 4^{+}\right)$derivados de Células Mononucleadas de Sangue Periférico foram isolados e transduzidos com partículas lentivirais pseudotipadas carregando shRNAs específicos contra cada proteína celular. Cinco dias após a transdução, o silenciamento da expressão endógenas nas proteínas celulares foi 
confirmado por "imunostainning" com anticorpos específicos utilizando uma alíquota da cultura celular (dados não mostrados). As células em cultura restantes foram infectadas com

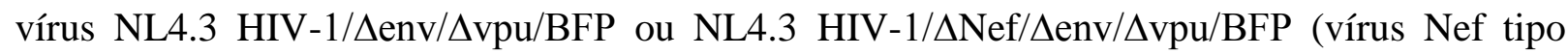
selvagem ou Nef deficiente, respectivamente) e incubadas por mais 2 dias. Finalmente, a expressão dos níveis de CD4 foram avaliadas por FACS (como descrito previamente), utilizando o programa Graph Pad Prism 6 (Figure 4.19).

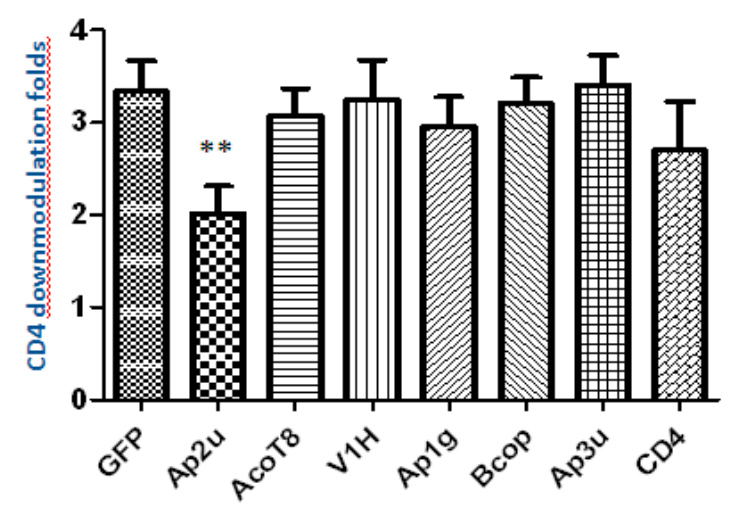

Figure 4.20. Modulação de CD4 mediada pela proteína Nef em linfócitos CD4 positivos isolados. A modulação de CD4 mediada por Nef foi avaliada na população de linfócitos CD4+isoldos de PBMCs duplamente infectados. Os linfócitos CD4+ foram transduzidos com particulas lentivirais codificando shRNAs e posteriormente infectados com partículas virais pseudotipadas de $\mathrm{HIV}-1 \mathrm{Nef}^{+/-}$. Os níveis de expressão de CD4 foram determinados por FACS, as células duplamente infectadas e os valores de MFI expressos foram analisadoas por Graph Pad Prism 6.

A relevância fisiológica da proteina AP2 na modulação de CD4 foi novamente confirmada em linfócitos de sangue periférico, desde que foi observada uma diminuição de aproximadamente duas vezes nos níveis de degradação de CD4 quando comparado com os apresentados pelo controle negativo, confrmando novamente dados prévios da literatura [78, 243, 246]. Já quanto a diminuição da expressão das outras proteínas celulares não foi possível identificar nenhuma redução significantiva na capacidade de Nef de degradar o receptor CD4. A falta de detecção de um efeito significativo na diminuição da expressão de CD4 mediada por Nef na presença de shRNAs específicos para outras proteínas celulares, envolvidas no trafego intracelular de vesículas, tal como $\beta$-COP, como observado com células SupT-1 [250], poderia obedecer a um menor requerimento por parte dos LT-CD $4^{+}$de sangue periférico, em termos de concentração desta proteína para a verificação deste fenomento, levando em consideração que nas condições experimentais do estudo o bloqueio da expressão das mesmas não é completo. Por outro lado é importante ressaltar que a completa depleção destas proteínas adaptadoras é tecnicamente difícil em células primarias já que a completa depleção destes fatores pode levar a morte celular. 
A respeito do exato mecanismo de modulação de CD4 mediada por Nef e a participação da proteína celular Ap2, dados da literatura têm se mostrado controversos quanto a participação destas proteínas no fenômeo de modulação de CD4 mediado por Nef, assim como suas consequências fisiológicas [247]. Dentre os principais pontos controversos, foi questionado se Nef levaria a modulação de CD4 da superfície celular por meio da degradação do complexo CD4/p56 $6^{\text {lck }}$ ou através da disrupção deste complexo [143, 251, 252]. Em estudos recentes foi demosntrado que a modulação de CD4 seria dependente da interação deste receptor com a proteína $\mathrm{p} 56^{\mathrm{lck}}$ sendo que a expressão de Nef diminuiria a interação entre ambas as proteínas [253]. De fato os niveis de internalização fisiológica de CD4 na presença de $\mathrm{p} 56^{\text {lck }}$ foram consideravelmente menores que na ausência desta proteína na superfície celular. Já na presença de Nef não foi possível observar nenhum aumento considerável na internalização de CD4 na ausência de $556^{\mathrm{lck}}$. Estes dados sugerem que a presença de Nef na membrana celular [254, 255], por um lado levaria a um aumento da concentração de Ap2 na superfice celular e pelo outro, a desestabilizar a interação $\mathrm{CD} 4 / \mathrm{p} 56^{\text {lck }}$, permitindo a exposição do motivo EXXXLL-165 da calda de CD4 e consequentemtne a interação com a proteína AP2 o que por sua vez levaria a internalização do receptor viral.

Por outro lado também existem importantes controvérssas quanto as consequências fisiológicas da modulação de CD4. Embora a endocitose de CD4 seja uma resposta fisiológica à ativação do receptor TCR, a modulação de CD4 mediada por Nef foi descrita com um fenômeno independente da ativação de linfócitos T e responsável pela modulação dos iniciais eventos no recrutamento de Lck e consequentemente a transdução de sinal via TCR. De fato estudos mostram que a modulçao de CD4 poderia alterar a sinalização mediada pela ativação do TCR [256, 257]. Entretanto outros estudos mostraram que a inibição da ativação de TCR por Nef é um fenômeno independente da modulação de CD4 [258-260].

Finalmente é importante ressaltar que os resultados deste estudo foram obtidos em linfócitos de sangue periférico e em condições naturais de infecção pelo HIV-1. Acreditamos que estas condições experimentais são o principal diferencial deste estudo, desde que para nosso conhecimento os trabalhos publicados até o momento objetivando o estudo deste mecanismo foram realizados utilizando apenas linhas de células T transformadas.

Em resumo, a partir dos resultados obtidos pelos experimentos do "Knock-down" dos putativos parceiros celulares de Nef na modulação de CD4 foi possível verificar que a interação AP2-Nef seria crucial para promover a modulação da proteína CD4 tanto na linha de células T, SupT1, como em linfócitos primários no contexto da infecção por HIV-1. 
Capítulo 5. Conclusões e Perspectivas 


\subsection{Conclusões}

As principais conclusões deste trabalho são resumidas a seguir:

As proteínas celulares mostraram diferentes níveis de interação com os alelos da proteína Nef NL4.3, NA7 e Mac239. As proteínas; AcoT8, AP2 $\mu$ e $\beta$-COP, foram as que apresentaram maiores níveis de interação com os alelos NA7 e NL4.3, do HIV-1, sendo que com o alelo NA7 mostraram um nível de interação maior do que com o alelo NL4.3. Entretanto a proteína $\mathrm{V} 1 \mathrm{H}$ não mostrou nivieis significativos de interação tanto com estes alelos como com o alelo Mac 239. Já com o alelo Mac239 de SIV, a proteína AP2 $\mu$ mostro um nível elevado de interação, ao contrário do apresentado pelas outras proteínas celulares, que não evidenciaram interação com este alelo. Por outro lado, a proteína celular CD4 mostrou relevante interação apenas com as proteínas celulares AP $2 \mu$ e $\beta$-COP. Estes resultados mostraram claramente a necessidade de realizar os ensaios entre cada proteína celular/alelo de Nef/CD4 em presença das outras proteínas celulares, com o intuito de verificar uma possível participação destas em cada ensaio, assim como usar células de linhas $\mathrm{T}$ que expressem o receptor CD4 (como explicado em Resultados \& Discussão).

A avaliação da conservação das interações antes descritas entre as diferentes cepas do vírus da Imunodeficiência presentes em primatas humanos e não humanos, mostrou uma interação significativa de $\beta$-Cop com as proteínas de Nef- AgmSab1, AgmTan1, NL4.3, NA7. Enquanto a proteína AcoT8 mostrou uma interação significativa apenas com os alelos NL4.3 e NA7. Já as moléculas CD4 e Ap2 $\mu$ mostraram os maiores níveis interação com a maioria dos alelos da protein viral Nef, tanto de primatas não humanos como primatas humanos, incluindo NL4.3 e NA7. A conservação nas interações entre a proteina viral Nef do HIV-1 com as proteínas celulares CD4, AcoT8, Ap2 $\mu$ e $\beta$-Cop sugeriu que estas proteínas poderiam estar direta ou indiretamente envolvidas na modulação de CD4 induzida por Nef.

Os valores de FRET resultantes dos experimentos de interação foram de uma maneira geral confirmados na microscopia confocal. Entretanto, nova informação foi obtida com estes experimentos, no que se refere a identificação de mudanças na localização endógena de certas proteínas celulares para regiões onde os alelos de Nef se localizavam. Claros exemplos são as proteínas AcoT8 na presença do alelo NA7, e a proteína AP2 $\mu$ na presença do alelo Mac239.

- O "know down" da expressão endógena dos putativos parceiros celulares de Nef na modulação de CD4 tanto na linhagem de células T, SupT-1, assim como em linfócitos de sangue periférico mostrou claramente a proteína Ap2 como o mais importante fator celular envolvido no mecanismo de modulação de CD4. 
- O impacto do "Knock-down" destas proteínas celulares, na modulação de MHC-I mediado por Nef mostrou as proteínas AP1, AcoT8 e VIH como fatores celulares envolvidos e importantes na modulação deste receptor de superfície celular. Dentre estes fatores a participação da proteína celular V1H é de particular interesse desde que, em nosso conhecimento, não existem descrições prévios na literatura sobre a participação desta proteína celular neste processo.

\subsection{Perspectivas}

Em base aos dados obtidos neste trabalho nós traçamos os seguintes objetivos:

1. Construir vetores de fusão e lentivirais que expressem shRNA para outras proteínas celulares também propostas como importantes no mecanismo de modulação de CD4 mediada por Nef como são as proteínas Epsin 15, Dynamina 2 e ARF1,

2. Reavaliar os níveis de interação de cada proteína celular com os diferentes alelos de Nef em presença de outras proteínas celulares que possam influenciar nas ditas interações.

3. Determinar a relevância fisiológica das proteínas Epsin 15, Dynamina 2 e ARF1 na modulação de CD4 mediada pelos diferentes alelos de Nef em linhas de celulas T e linfoitos de sangue periférico infectados pelo HIV-1.

4. Elucidar o papel das proteinas celulares ACOT8, Ap1 e V1H na modulação do receptor MHC-I mediada por Nef.

5. Determinar a relevância fisiológica das proteínas ACOT8 15 e V1H na modulação de MHC-I mediada pelos diferentes alelos de Nef em linfoitos de sangue periférico infectados pelo HIV-1. 


\section{PARTE II}




\section{Lista de Figuras}

Figura 1.1. Modulação de CD4 mediada pela proteina viral Vpu

Figura 1.2. Modulação da proteina celular Bst2-Tetherin mediada pela proteinaVpu e liberação de particulas virais. .6

Figura 1.3. Inibição da ativação do fator de transcrição NFK-B pela proteina Vpu do HIV-1...7

Figura 4.1. Alinhamento das sequências de aminoácidos das cepas B, C, F e os recombinantes BF. .20

Figura 4.2. Caracterização da expressão dos isolados e recombinantes da proteína Vpu .22

Figura 4.3. Interação entre CD4 e isolados da proteína viral Vpu. .23

Figura 4.4. Interação entre Bst-2 e a proteína Vpu. .24

Figura 4.5. Modulação de CD4 por alelos de Vpu. .25

Figura 4.6. Degradação de Bst-2 por isolados de Vpu. .25

Figura 4.7. Nivies de infecção de partículas virias produzidas na presença de diferentes isolados de $\mathrm{Vpu}$. .26

Figura 4.8. Níveis de inibição do NFK-B por isolados de Vpu .27 


\section{Lista de Tabelas}

Tabela 3.1. Listagem de anticorpos.

Tabela4.1. Alelos de Vpu e suas cepas primárias. .21 


\section{Sumário}

\section{CAPÍTULO 1.}

1.1. Introdução .5

\section{CAPÍTULO 2. Relevância da Pesquisa e Objetivos}

2.1. Relevância da Pesquisa..................................................................................................... 10

2.2. Objetivos

2.2.1. Objetivo geral

2.2.2. Objetivos específicos

\section{CAPÍTULO 3. Materiais e Métodos}

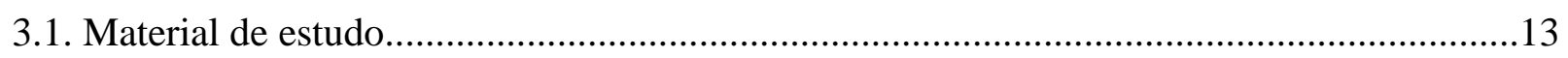

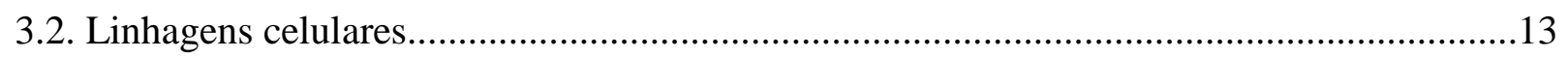

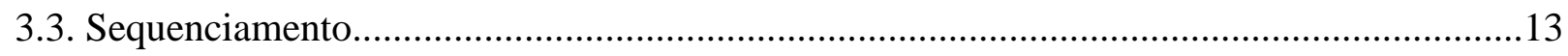

3.4. Produção e quantificação de partículas virais..................................................................14

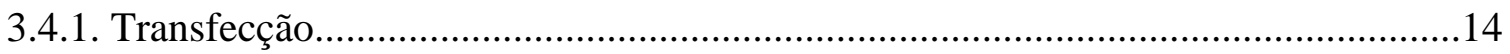

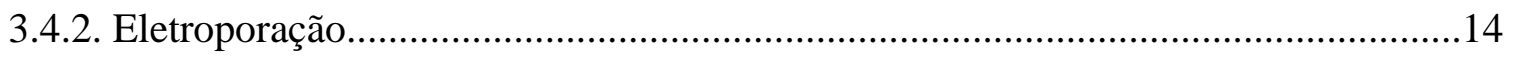

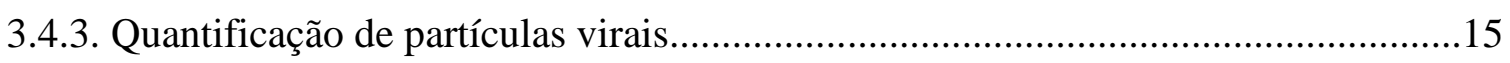

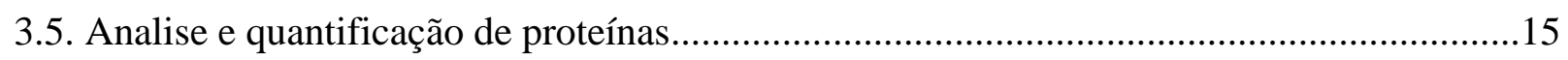

3.5.1. Preparação de extrato proteico......................................................................... 15

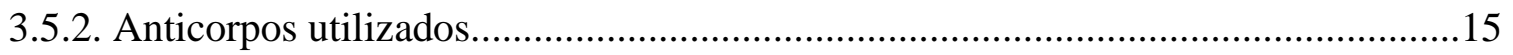

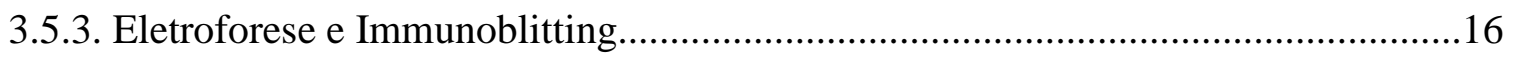

3.6. Frequência Ressoante de Energia Transferida - FRET ....................................................17

3.6.1. Transfecção de células para FRET .................................................................... 17

3.6.2. Frequência Ressoante de Energia Transferida (FRET/FACS)................................17

3.7. Avaliação da modulação da expressão das moléculas de superfície CD4 e BST-2, infectividade e ativação do fator NFK-B pelos diferentes alelos de Vpu..................................17

3.7.1. Determinação dos níveis de modulação de CD4 e BST-2 por Vpu........................17

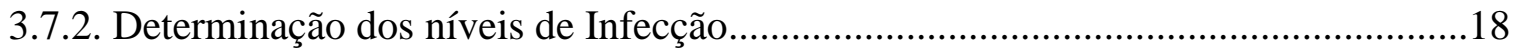

3.7.3. Determinação dos níveis de inibição do fator NFK-B por Vpu..............................18

\section{CAPITULO 4. Resultados e Discussão}

4.1. Sequenciamento e alinhamento dos diferentes alelos do gene Vpu..................................20

4.2. Construção de vetores de expressão de proteínas de fusão................................................21 
4.3. Caracterização da expressão dos isolados e recombinantes da proteína Vpu.

4.4. Caracterização da interação das proteínas celulares CD4 e Bst-2 com os isolados primeiros e recombinantes da proteína $\mathrm{Vpu}$. .23

4.5. Determinação dos níveis de modulação de CD4 e Bst-2 pelos diferentes alelos de Vpu....24

4.6. Determinação dos níveis de infecção induzidos pelos diferentes alelos de Vpu.................26

4.7. Determinação dos níveis de inibição do fator de trarnscrição NFK-B induzidos pelos diferentes isolados de $\mathrm{Vpu}$

\section{CAPITUlO 5. Conclusões e Perspectivas}

5.1. Conclusões. 30

5.2. Perspectivas... .30

CAPITULO 6. Referências Bibliográficas .31

\section{CAPITULO 7. Anexos}

7.1. Alinhamentos das proteínas celulares fusionadas. .59

7.2. Lista de vetores fusionados a CFP/YFP. .62

7.3. Lista de plasmídeos para produção de partículas virais. 
Caracterização de Alelos da Proteína Vpu Presentes em Recombinantes BF do HIV-1 Circulantes na América do Sul 


\section{RESUMO}

A Proteína acessória Vpu, do vírus da imunodeficiência adquirida humana (HIV-1), exerce um importante papel na infecção, replicação e patogênese viral. Dentre as principais funções biológicas atribuídas a esta proteína viral encontram-se a liberação de partículas virais; a indução da degradação do receptor viral CD4, Bst-2, dos ligantes CD1d, NK-T de células NK e NTB-A de células B e a inibição da ativação do fator de transcrição NFK- $\beta$. Por outro lado o gene Vpu é uma das regiões mais variáveis do genoma do HIV-1. Estas propriedades tornam esta proteína um excelente alvo de estudo visando o entendimento dos mecanismos envolvidos na interação vírus - célula hospedeira e consequentemente na identificação de novos alvos e abordagens terapêuticas.

Achados epidemiológicos na América do Sul mostraram o surgimento de recombinantes entre os subtipos B e F. Estudos moleculares posteriores mostraram que a recombinação entre ambos os subtipos afetou o gene vpu, dentre outras regiões do genoma viral, resultando em alterações funcionais vantajosas para replicação desses recombinantes. Entretanto, importantes questões ainda permanecem sem resposta, tais como: a) quais são as implicações da recombinação entre subtipos virais na atividade biológica de Vpu?; b) Como podem estas modificações influenciar a infectividade e replicação viral? Nesse contexto, neste projeto caracterizamos algumas funções dos alelos de Vpu derivados de cepas dos subtipos B, C, F e isolados, assim como seus respectivos recombinantes BF. Os alelos recombinantes BF mostraram se ligar e degradar o receptor CD4 com a mesma eficiência que seus parentais. Por outro lado, embora estes recombinantes se liguem com mais eficiência a proteína Bst2 e sejam mais eficientes na indução de infectividade e possivelmente na promoção da liberação viral que seus parentais, eles não mostraram diferenças quanto a degradação desta proteína celular. Finalmente, um recombinante $\mathrm{BF}$ foi mais eficiente na ativação do NFK-B, o que poderia permitir uma maior sobrevida celular e consequentemente replicação viral. Estes resultados nos permitem chegar a conclusão parcial que a maior capacidade de se ligar a Bst2 e promover infecção, assim como no caso de de um dos recombinantes de não inibir a ativação do fator NFK-B, poderia explicar, ao menos em parte, a maior infectividade apresentada por estes vírus em relação a seus parentais e consequentemente a propagação destes na américa do sul. Em próximos estudos esperamos avaliar a capacidade destes recombinantes em degradar os receptores CD1d, NKT e NTB, assim como elucidar o mecanismo pelo qual os recombinantes induzem uma maior liberação viral ainda que não apresentem uma maior degradação do inibidor Bst2.

Palavras chave: Vpu, Recombinante BF, Subtipos de Vpu B, C, F; HIV-1; Bst-2; Teterina, CD317; NFK-B 


\begin{abstract}
The accessory Vpu protein of the human immunodeficiency virus (HIV-1) plays an important role during the infection, viral replication, and pathogenesis. Among the most important biological roles assigned to this viral protein are: the release of viral particles; inducing the viral receptor CD4 degradation of BST-2, CD1d ligands, NK T-NK cells NTB-A and B-cells, and the inhibition of activation of NFK- $\beta$ transcription factor. On the other hand, the $\mathrm{Vpu}$ gene is one of the most variable regions of the HIV-1 genome. These properties make this protein an excellent subject of study in order to understand the mechanisms involved in the interaction virus-host cell, and therefore, the identification of new targets and therapeutic approaches.
\end{abstract}

Epidemiological findings in South America have shown the appearance of recombinants between subtypes B and F. Subsequent studies have shown that the molecular recombination between the two subtypes affect the vpu gene, among other regions of the viral genome. This yield recombinant alterations resulting in advantages in functional replication. However, important questions still remain unanswered; such as: a) what are the implications of recombination between viral subtypes in the biological activity of Vpu? b) How can these changes influence the infectivity and viral replication? In this project features various functions of the $\mathrm{Vpu}$ alleles derived from strains of subtypes B, C, F, and isolates, as well as their BF recombinants. BF Recombinant alleles showed bind and degrade the CD4 receptor with the same efficiency as their parental strains. Moreover, these recombinant showed an increased efficiency to bind Bst 2 protein, along with a higher infectivity, and was possibly promoted by an increased viral release than their parents. Even though they did not show more efficiency to degrade Bst2 protein. Lastly, one recombinant BF was more efficient in the NFK-B activation. These results allowed us to obtain the main conclusion that the ability to bind to Bst 2 and viral infectivity, could explain, at least in part, their spread in South America. In further studies, we expect to evaluate other $\mathrm{Vpu}$ functions, such as the CD1d receptor and the NTB NKT degradation, and elucidate the mechanism by which viral recombinants induce increased release, but have not shown further degradation of Bst 2 inhibitor.

Key-words: Vpu, Recombinant BF, Vpu subtipes B, C, F; HIV-1; Bst-2; Thetherin CD317; NFK-B 


\section{Capítulo 1. Introdução}


Há mais de 30 anos da descoberta do vírus da imunodeficiência humana (HIV) como agente etiológico da síndrome da imunodeficiência adquirida (AIDS), a pandemia da AIDS continua a superar todas as expectativas em termos de gravidade e impacto sócio global. Assim, cerca de 60 milhões de pessoas já foram infectadas, 20 milhões de pessoas morreram como consequência da infecção pelo HIV, e mais de 2 milhões de mortes relacionadas com a AIDS ocorrem a cada ano [20].

Apesar dos evidentes benefícios da terapia antiviral (ART) na diminuição da carga viral, taxa de mortalidade e no índice de pacientes infectados, diversas limitações, tais como: aparecimento de variantes virais resistentes a drogas anti-retrovirais [261], a formação de reservatórios virais latentes no hospedeiro, bem como o efeito tóxico do tratamento [217-219] são responsáveis pela persistência do patógeno ainda em pacientes tratados.

Dentro deste contexto é crucial o entendimento dos mecanismos envolvidos na complexa interação vírus - célula hospedeira e consequentemente a identificação de novos alvos e abordagens terapêuticas.

A proteína viral "u” (Vpu), é uma proteína acessória associada à membrana e pode ser dividida em dois domínios: de transmembrana (1-27 aa) e citoplasmáticos (hélice $\alpha-1$, resíduos 32-51 aa; hélice $\alpha-2$, resíduos 57 -72 aa) [262, 263]. Estes domínios estão relacionados às duas principais funções biológicas, a liberação de partículas virais e a degradação do receptor CD4, respectivamente.

Entre os importantes mecanismos patogênicos virais em que participa esta proteína se pode citar: a) a diminuição da expressão da molécula CD4 na célula hospedeira [99, 264, 265] [48] [266](Figura 1).

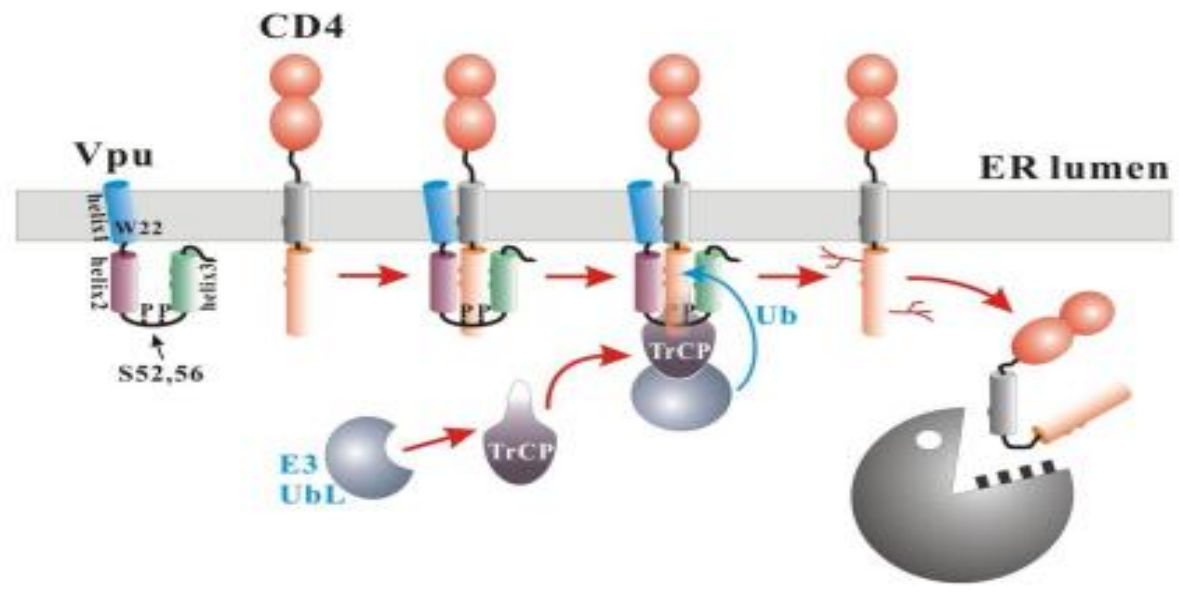


Figura 1.1. Degradação de CD4 mediada pela proteina viral Vpu. O processo de degradação de CD4 mediado por Vpu envolve múltiplos passos, começando pela ligação de Vpu à calda citoplasmática de CD4 [265]. Posteriormente a fosforilação dos resíduos de Ser52 e Ser56, e principalmente por meio da pSer52, por uma caseína cinase II celular, permite a Vpu se ligar a uma proteína contendo repetições de F-box- $\beta$-transducina ( $\beta$ $\operatorname{TrCP}$ ), um componente do complexo de ligação ao complexo E3 ubiquitina, o $\operatorname{SCF} \beta^{-\operatorname{TrCP}}$ o que permite o direcionamento da molécula CD4 para degradação proteassomica [267] (Figura retirada de [266]).

b) a liberação das partículas virais das células infectadas mediante a formação de canais de íons [265, 268] e pela inibição de duas proteínas celulares inibitórias da liberação viral, Tetherin/Bst-2/CD317, induzida por interferon- $\alpha$ [52] (Figura 1.2) e a proteína integral de membrana ligante de ciclofilina B [52, 269]

A

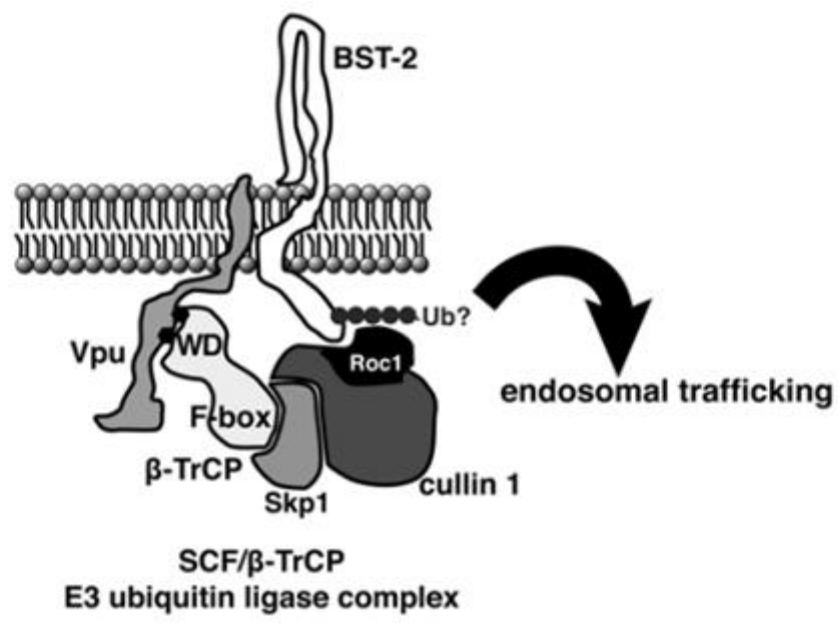

B

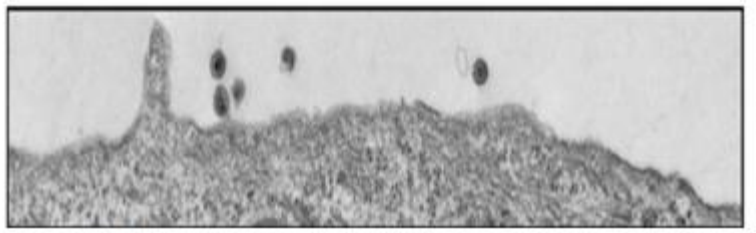

HIV-I (WT)

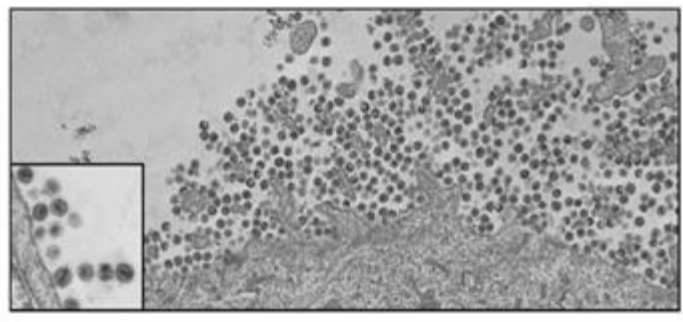

HIV-I (delVpu)

Figura 1.2. Degradação da proteina celular Bst2-Tetherin mediada pela proteinaVpu e liberação de particulas virais. A)Após a ligação de Vpu na porção transmembrânica de Bst2, a proteina Vpu recruta o complexo $\beta$-Transducin E3 ubiquitin ligase e promove a degradação de Bst-2 presente no golgi por via lisossômica ou proteassômica, promovendo o bloqueio da atividade negativa de Bst-2 e favorecendo a liberação viral (Figura retirada de[270]). B) Fotografia eletronica de células infectadas com virus contendo a proteina Vpu WT (a direita) e virus com esta proteina viral defeituosa ( a esquerda) (Figura retirada de [52]).

c) a inibição da expressão da molécula apresentadora de antígeno CD1d [271] e dos ligantes de ativação de células NK, NK-T [272, 273] e das células B (NTB-A) [274, 275], d) a inibição da 
ativação do fator de transcrição NFK- $\beta$ [266, 276, 277] (Figura 1.3) e e) a diminuição da expressão da molécula de complexo principal de histocompatibilidade clase II (MHC-II) [278].

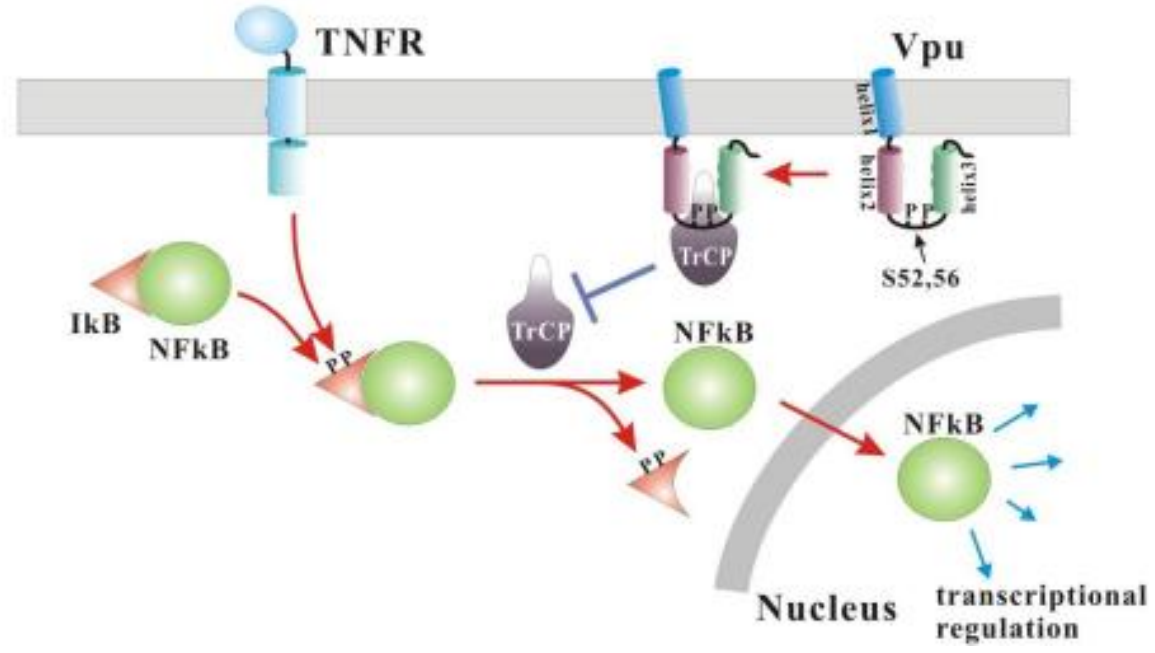

Figura 1.3. inibição da ativação do fator de transcrição NFK-B pela proteina Vpu do HIV-1. O fator NFkB esta presente de forma inativa no citoplasma e ligado ao seu inibidor IkB. Após ativação celular pelo fator de necrose tumoral (TNF), o inibidor IkB é fosforilado desligando-se do NFK-B_e segue para a degradação proteassomica via $\beta$-TrCP por indução de ubiquitinização. Após liberaçao de seu inibidor o fator NFkB migra ao nucleo e é responsável pela ativação do processo transcricional. O bloqueio da ativação do NFkB por Vpu obedece ao secuestro do complexo $\beta$-TrCP por parte da proteina viral e conseqeuente inibição da degradação do IKB (Figura retirada de [266]).

A sequência de Vpu é uma das regiões mais variáveis do genoma do HIV-1 e foi mostrado que diferenças na função desta proteína entre os principais grupos do HIV-1, grupo $\mathrm{M}$ vs $\mathrm{N}$ e $\mathrm{O}$, podem ter tido um impacto importante na patogenicidade e transmissão destas variantes virais [279, 280]. Achados epidemiológicos na Argentina sugerem um cenário semelhante quanto às variações detectadas nos recombinantes entre os subtipos B e F [281287]. Estudos moleculares posteriores mostraram que a recombinação entre os subtipos BF afetou o gene da proteína $\mathrm{Vpu}$, dentre outras regiões do genoma viral, resultando em alterações funcionais vantajosas para replicação viral [288]. Entretanto, é atualmente desconhecido se a variabilidade e a diversidade dos alelos de $\mathrm{Vpu}$ destes recombinantes afetam a função da proteína e, portanto, a patogenicidade viral. Além disso, a maioria dos estudos estruturais e funcionais existentes sobre $\mathrm{Vpu}$ foram realizados apenas em cepas adaptadas de laboratório do subtipo B (NL4-3 ou HXB2) [266] ou subtipo C, [289].

A pesar do amplo conhecimento molecular sobre diferentes subtipos genéticos e a dinâmica do surgimento dos recombinantes, importantes questões ainda permanecem sem 
resposta, tais como: a) quais são as implicações da recombinação entre subtipos virais, na atividade biológica de Vpu?; b) Como podem estas modificações influenciar a infectividade e replicação viral?

Neste contexto neste projeto nos propomos determinar o impacto das variações detectadas nos alelos Vpu presentes em cepas de referência dos subtipos B, C e F, isolados primários e seus respectivos recombinantes BF derivados de pacientes infectados, nas funções relacionadas a modulação das proteínas celulares CD4 e BST-2 e liberação viral, assim como na regulação da ativação do fator NFK-B. 


\section{Capítulo 2. Relevância da Pesquisa e Objetivos}




\section{Relevância da Pesquisa e Objetivos}

\subsection{Relevância da pesquisa}

A implantação da terapia antiviral (ART) proporcionou um grande avanço no tratamento da infecção pelo HIV-1, levando à diminuição na carga viral, na taxa de mortalidade e no índice de pacientes infectados. Apesar dos evidentes benefícios do tratamento, surgiram diversos inconvenientes relacionados à terapia, tais como: aparecimento de variantes virais resistentes a drogas anti-retrovirais [261] a formação de reservatórios virais latentes no hospedeiro, bem como o efeito tóxico do tratamento [217-219], sendo estes responsáveis pela persistência deste patógeno ainda em pacientes tratados.

Dentro deste contexto se faz necessária a identificação de novos alvos e desenvolvimento de novas abordagens terapêuticas. Sendo assim é crucial o entendimento dos mecanismos envolvidos na complexa interação vírus - célula hospedeira durante as diferentes fases da infecção [290].

Os diferentes níveis de progressão à AIDS observados nos pacientes infectados pelo HIV-1 é talvez um dos mais intrigantes fenômenos desta doença [291-294] e certamente são determinados por uma complexa interação entre fatores genéticos do hospedeiro e do vírus [295-297]. Para o vírus, o ambiente é variável sofrendo constantes flutuações no tempo e espaço. Certamente os mecanismos de defesa do hospedeiro destinados a erradicar o vírus e evitar o estabelecimento de uma infecção crônica (imunidade inata e adaptativa), juntamente com a terapia antirretroviral, representam as principais forças modificadoras [298, 299]. Estas forças exercem uma enorme pressão seletiva que levam a recombinações, alterações no material genético e consequentemente no "fitness" viral, o que finalmente define a habilidade de certos genótipos de produzirem progênies virais em determinados microambientes [300] [301].

Por esse motivo, o estudo das modificações genéticas virais e suas consequências biológicas são de vital importância no entendimento da dinâmica evolucionária da população viral e dos mecanismos patogênicos envolvidos na infecção pelo HIV-1 [290, 302, 303]. Dentre os fatores virais, encontra-se a presença de mutações - alterações em domínios de regiões biologicamente ativas de várias proteínas virais. 
Dessa forma, a determinação da relevância fisiológica das alterações presentes nos alelos Vpu em diferentes recombinantes derivados de pacientes infectados na América do Sul e sua correlação com os parâmetros clínicos, nos poderá permitir numa etapa posterior estabelecer protocolos, nos quais as análises genotípicas e fenotípicas das populações virais possam ser usadas no prognóstico da evolução da infecção, assim como no estabelecimento de novas abordagens terapêuticas.

\subsection{Objetivos}

\section{Geral}

Avaliar a capacidade dos alelos Vpu presentes nos subtipos (B, C e F), isolados primários e seus recombinantes BF do HIV-1 em modular a expressão das moléculas de superfície CD4, BST-2, liberação viral e regular a ativação do fator NFK-B.

\section{$>$ Específicos}

1. Caracterizar as sequências dos alelos Vpu derivados de diferentes subtipos do HIV-1 (B, C e F), isolados primários e as variantes recombinantes BF,

2. Avaliar, comparativamente, a capacidade dos alelos de Vpu dos subtipos (B, C e F), isolados primários e dos recombinantes $\mathrm{BF}$ de se ligar, assim como de modular a expressão das proteínas CD4 e BST-2 da superfície celular;

3. Avaliar, comparativamente, a capacidade dos alelos de Vpu dos subtipos (B, C e F), isolados primários e dos recombinantes BF de promover infecção celular;

4. Avaliar a regulação da ativação do fator NFK-B mediada pelos alelos de Vpu dos diferentes subtipos $\mathrm{B}, \mathrm{C}$ e F e isolados primários em relação a recombinante BF; 


\section{Materiais e Métodos}




\subsection{Material de estudo}

Os diferentes alelos do gene Vpu derivados de diferentes subtipos de HIV (B, C e F) e as variantes recombinantes BF clonados no vetor pCG-6His-IRES-GFP foram cedidos gentilmente pelo Dr. Mauricio Carobene da Faculdade de Medicina da Universidade de Buenos Aires, como parte de um projeto em colaboração com o citado pesquisador e o Dr. Michael Schindler do Centro Helmholtz de Munique.

\subsection{Linhagens celulares}

Para a produção de partículas virais foi utilizada a linhagem celular aderente de fibroblastos de rim humano denominada $293 \mathrm{~T}$ foi cultivada a $37^{\circ} \mathrm{C}$ em atmosfera de $5 \%$ de $\mathrm{CO}_{2}$ em meio de cultura Dulbecco Modified Eagle Medium (DMEM) suplementado com 10\% de Soro Bovino Fetal inativado (SFB). Os experimentos de avaliação da capacidade dos alelos Vpu dos subtipos (B, C e F) e dos recombinantes BF do HIV-1 em modular a expressão das moléculas de superfície CD4, BST-2, e regular a ativação do fator NFK-B foram realizados na linha celular de linfócitos T, SupT-1. Esta linhagem celular foi cultivada a $37^{\circ} \mathrm{C}$ em atmosfera de $5 \%$ de $\mathrm{CO}_{2}$ em meio de cultura Roswell Park Memorial Institute (RPMI 1640) suplementado com 10\% de Soro Bovino Fetal inativado (SFB).

A infectividade dos vírus produzidos a partir de vetores pCG-GFP carregando os diferentes alelos de Vpu foi avaliada em células "repórter" LC5-RIC-R5. Esta linha celular foi derivada de uma sub-linha celular HeLa modificada para expressar o receptor viral CD4 (LC5-CD4) [304] e o co-receptor viral CCR5 na superfície celular [305]. Esta linha celular contém como gene repórter a proteína fluorescente vermelha dependente da expressão das proteínas virais Rev e Tat.

\subsection{Sequenciamento}

Os diferentes alelos de Vpu clonados no vetor pCG-His6 foram sequenciados em ambas as direções pela empresa de sequenciamento "SeqLab" e as sequencias obtidas analisadas pelo software Multalin Interface. 


\subsection{Produção e quantificação de partículas virais}

A produção de partículas virais obedece ao protocolo descrito no item 3.1 da primeira parte desta tese, "Adaptador de Clatrina AP2, é fator celular crítico para a modulação do receptor celular CD4 mediada pela proteína viral Nef do Virus da Imunodeficiência Humana Tipo 1, em células primárias de linfócitos". Contudo o acréscimo e/ou substituição de vetores específicos à cada um dos experimentos deste trabalho serão descritos abaixo.

\subsubsection{Transfecção}

As partículas virias foram obtidas por transfecção de células 293T pela técnica de precipitação de fosfato de cálcio. Resumidamente, 24 horas antes do experimento as células foram ressuspensas em solução de tampão fosfato (PBS) 1X e colocadas em

placas de transfecção de vinte e quatro poços a densidade de $4 \times 10^{4}$ células/poço em 500 $\mu 1$ de meio de cultura DMEM suplementado.

Todos os experimentos foram realizados em triplicata colocando em cada poço, 1 $\mu \mathrm{g}$ total de DNA plasmideal em uma relação de: $0,2 \mu \mathrm{g} / 0,02 \mu \mathrm{g} / 0,8 \mu \mathrm{g}$, distribuídas entre o vetores pCG-EGFP (carregando os diferentes alelos da proteína viral Vpu), adicionalmente com vetor pCG para expressão de CD4 ou Bst-2 e conjuntamente com o vetor lentiviral $\mathrm{pBR}-\mathrm{NL} 43 / \Delta$ nef/ $\Delta$ vpu para expressão do vírus HIV-1 deficiente, diluídos em $270 \mu 1$ de água destilada e 52,5 $\mu 1 \mathrm{de}^{\mathrm{CaCl}_{2}}$ 0,5 M. Paralelamente, para a formação dos cristais de fosfato de cálcio, a solução contendo o DNA plasmideal foi acrescentada gota a gota a $375 \mu \mathrm{l}$ de uma solução $2 \mathrm{X} \mathrm{HBS}\left(\mathrm{NaCl} 280 \mathrm{mM}\right.$; KCl $10 \mathrm{mM} ; \mathrm{Na}_{2} \mathrm{HPO}_{4} 1.5$ mM; dextrose $12 \mathrm{mM}$; Hepes $50 \mathrm{mM}$ ) sob agitação. Finalmente, a solução de transfecção foi espalhada gota a gota sobre a camada de células. Entre 8-16 horas após transfecção, o meio de cultura inicial foi retirado e adicionado meio novo. Após 72 horas da transfecção, os sobrenadantes contendo as partículas virais foram recolhidos e estocados à $-86^{\circ} \mathrm{C}$.

\subsubsection{Eletroporação}

Células SupT-1 foram infectadas por eletroporação com DNA proviral correspondente a cada cepa ou isolado. Brevemente dez milhões de células SupT-1 ( $1 \times 10^{7}$ células $\left./ \mathrm{ml}\right)$ foram eletroporadas sobre as seguintes condições; $420 \mathrm{~V}$ de voltagem, 960 uF de capacitância e resistência de 100 ohms obtendo-se entre 40-50\% de células 
vivas e uma eficiência de transfecção acima de 50\%. O equipamento empregado para eletroporação foi Gene Pulser I (Bio-Rad). A avaliação da viabilidade celular tanto antes quanto após o pulso foi realizada empregando teste de exclusão por azul tripan. A eficiência de transfecção foi observada 48 hs após eletroporação, sendo então as células analisadas através de citometria de fluxo quanto a expressão da proteína EGFP.

\subsubsection{Quantificação de partículas virias}

A quantificação da produção das partículas lentivirais foi realizada pela técnica de ELISA utilizando o kit "HIV-1 p24 Antigen ELISA" (RETROtek ZeptoMetrix Corporation - USA) e anticorpo específico para a proteína viral p24.

\subsection{Analise e quantificação de proteínas}

\subsubsection{Preparação do extrato proteico}

A extração de proteínas celulares foi realizada através da adição de tampão RIPA (50 mM Tris-HCl, pH 7.4; 1\% NP-40; 0.25\% deoxicolato de sódio; $150 \mathrm{mM} \mathrm{NaCl;} 1$ mM EGTA; $1 \mathrm{mM}$ PMSF; $1 \mu \mathrm{g} / \mathrm{ml}$ cada de aprotinina, leupeptina, pepstatina; $1 \mathrm{mM}$ $\mathrm{Na}_{3} \mathrm{VO}_{4} ; 1 \mathrm{mM} \mathrm{NaF}$ ) sob vigorosa agitação e subsequente centrifugação a $14.500 \mathrm{rpm}$ para eliminação de restos celulares que ficaram no fundo do tubo.

As determinações das concentrações de cada extrato proteico foram realizadas pelo método descrito por "Bradford Protocol - 1976" utilizando-se albumina sérica bovina (Sigma $\left.{ }^{\circledR}\right)$ como padrão.

\subsubsection{Anticorpos utilizados.}

Os anticorpos utilizados neste trabalho se encontram listados abaixo (tabela 3.1), assim como suas respectivas companhias.

\begin{tabular}{llcc}
\hline Reagente & Produzido & Produzido & Número de catálogo \\
\hline Anti CD4 & camundongo & BD Biosciences & 555347 \\
Anti-Bst-2 & coelho & ABCAM & $\underline{\text { ab109854 }}$ \\
Anti-Vpu & camundongo & BD Biosciences & 578975 \\
Anti-YFP & rato & ABCAM & $\underline{\text { ab290 }}$
\end{tabular}

Tabela 3.1. Listagem de anticorpos. Lista de anticorpos utilizados, demonstrando em que animal foi produzido, se o anticorpo está conjugado com alguma enzima ou fluorocromo, a companhia produtora do 
reagente e o número de catálogo.

\subsubsection{Eletroforese e Immunoblotting}

Aproximadamente $15 \mu \mathrm{g}$ dos diferentes extratos proteicos foram submetidos à eletroforese em gel de poliacrilamida na presença de dodecil sulfato de sódio (SDSPAGE), sob condições desnaturantes e redutoras, conforme método originalmente descrito por "Laemmili Protocol - 1970”. Para isso utilizou-se o sistema de eletroforese vertical e os géis foram preparados com concentração de $10 \%$ para o gel separador e $4 \%$ para o gel concentrador (Current Protocols in Molecular Biology). As amostras foram diluídas em tampão de amostra 5x (Tris- $\mathrm{HCl} 50 \mathrm{mM}, \mathrm{pH}$ 6,8; SDS 2\%; azul de bromofenol 0,1\%; $\beta$-mercaptoetanol (2-Me) $15 \mathrm{mM}$ e glicerol 10\%) e fervidas por $5 \mathrm{~min}$. antes de serem aplicadas no gel. A eletroforese foi realizada em tampão de corrida (Tris$\mathrm{HCl} 25$ mM, pH 8,8; glicina $250 \mathrm{mM}$ e SDS 0,1\%) à voltagem constante de $70 \mathrm{~V}$ e de $150 \mathrm{~V}$ durante a passagem das amostras pelo gel concentrador e separador, respectivamente. Como padrão de massas moleculares para o experimento de eletroforese, utilizou-se o marcador comercial da Bio-Rad: Precision Plus Protein Kaleidoscope Standards (MW: $10-250 \mathrm{kDa}$ ).

Após eletroforese, as proteínas foram transferidas para uma membrana de nitrocelulose em sistema semisseco de transferência horizontal (Trans-Blot SD Semi-Dry Transfer Cell, Bio-Rad), conforme as recomendações do fabricante. A transferência teve duração de $80 \mathrm{~min}$. a corrente constante de $0,8 \mathrm{~mA} / \mathrm{cm}^{2}$, em tampão de transferência (Tris-HCl 48,4 mM; Glicna 39 mM; SDS 0,037\% e Metanol 20\%). Após a transferência, a membrana foi incubada em tampão de bloqueio (PBS 1X, Twen20 0,2\% e Leite em pó desnatado 5\%) por 1 hora a temperatura ambiente em agitação constante.

A membrana foi lavada três vezes em tampão de lavagem (PBS adicionado de Tween 20 0,2\%) e então incubado com o anticorpo primário especifico para cada proteína diluído 1:200 em PBS 1X contendo 1\% de leite em pó desnatado (PBS-Leite), por 1 hora. Após duas lavagens de 10 min. cada, com tampão de lavagem, a membrana foi incubada com o anticorpo secundário conjugado com fosfatase alcalina, na diluição de 1:2000 em tampão PBS Leite por 1 hora à temperatura ambiente. Após três lavagens com tampão de lavagem, de 10 min. cada, foi adicionado à membrana solução reveladora contendo $66 \mu \mathrm{l}$ de p-nitro azul tetrazólico (NBT) (Gibco-BRL) e $33 \mu$ de 5-bromo-4cloro-3-indolil- 
fosfato (BCIP) (Gibco-BRL) em $10 \mathrm{ml}$ de tampão Tris-HCl 100mM pH 9,5; NaCl 100 $\mathrm{mM} ; \mathrm{MgCl}_{2} 5 \mathrm{mM}$. A reação de revelação foi interrompida com lavagens sucessivas com água destilada. As massas moleculares das proteínas eram conferidas de acordo com o marcador utilizado no gel.

\subsection{Fluorescence Resonance Energy Transfer - FRET}

\subsubsection{Transfecção de células para ensaios de FRET}

Células 293T foram transfectadas por técnica de fosfato de cálcio (técnica citada no tópico "3.4.1. Transfecção de células"), onde $1,5 \times 10^{5}$ células foram plaqueadas em placas de 12 poços com $1 \mathrm{~mL}$ de meio de cultura DMEM suplementado. Para cada poço, $2,5 \mu \mathrm{g}$ (quantidade total) de DNA plasmideal foram distribuídas, sendo 1,25 $\mu \mathrm{g}$ do vetor CFP e 1,25 $\mu \mathrm{g}$ do vetor YFP, fusionados às sequências de genes que expressam as diferentes proteínas celulares. Após 24-36 horas os sobrenadantes dos poços foram descartados e as células foram recolhidas e lavadas duas vezes com PBS+EDTA. Após a última lavagem, as células foram ressuspensas em $200 \mu \mathrm{l}$ de paraformaldehido $2 \%$ à $4^{\circ} \mathrm{C}$.

\subsubsection{Frequence Resonance Energy Transfer (FRET/FACS).}

Nas medições de FACS/FRET foram feitas utilizando o aparelho FACS CANTO III (BD Bioscience) equipado com os lasers de $405 \mathrm{~nm}, 488 \mathrm{~nm}$ e $633 \mathrm{~nm}$. Para medir ECFP e FRET as células foram excitadas com o laser de $405 \mathrm{~nm}$. O resultado foi "plotado" no canal ECFP com o filtro padrão 450/40, enquanto o sinal de FRET foi medido com o filtro 529/24 (Semrock). Para medir EYFP, as células foram excitadas com o laser de 488nm, entretanto a emissão também era captada no filtro 529/24 (Semrock).

\subsection{Avaliação da modulação da expressão das moléculas de superfície CD4 e BST-2, infectividade e ativação do fator NFK-B pelos diferentes alelos de Vpu}

\subsubsection{Determinação dos níveis de modulação de CD4 e BST-2 por Vpu}

Os níveis de expressão dos receptores CD4 e Bst2 foram avaliados em células transfectadas e eletroporadas (SupT-1 e Hela, respectivamente) com vetores codificando os diferentes alelos de Vpu e quantificados por FACS utilizando anticorpos fluorescentes específicos, 48 horas após. Para isto as células foram lavadas duas vezes com solução de PBS 1X e incubadas por 45 min no gelo com os anticorpos específicos para cada proteína 
celular a uma concentração de $2 \mu \mathrm{L} / \mathrm{ml}$ em PBS. Posteriormente, as células foram lavadas duas vezes com PBS 1X e ressuspensas em $200 \mu \mathrm{l}$ de PBS $+2 \%$ SFB. Os dados foram analisados por citometria de fluxo, FACS CANTO III, utilizando as seguintes florescências e seus respectivos filtros: GFP (530/30), PE (585/42) e APC (660/20), sendo GFP referente a expressão dos alelos de Vpu, PE referente a a expressão da proteína Bst-2 e APC referente a a expressão do receptor CD4. Os resultados foram analisados com o programa Diva (BD Biosciences).

\subsubsection{Determinação dos níveis de Infecção}

Com objetivo de avaliar o nível infeccioso das partículas virais produzidas em células HEK 293T codificando os diferentes alelos de Vpu, (descrito no item 3.4.1 deste capítulo), células Hela-LC5-RICR5 foram semeadas em placa de 96 poços e infectadas com as diferentes partículas virais. Brevemente, no $1^{\circ}$ dia (final da tarde) 10.000 células Hela-Ric foram semeadas [306] em placas "Grainer 96-Black flat" e infectadas com $20 \mu 1$ sobrenadante viral em concentração final de $1 \mu \mathrm{g}$ de p24, 48 após a infecção se procedeu a remoção do meio e a leitura dos níveis de infecção em leitor de placas - Tecan respeitando os seguintes parâmetros: Excitação do comprimento de onda: 552 nm; Emissão do comprimento de onda: 596 nm e 25 flashes e "Força" em "ótima".

\subsubsection{Determinação dos níveis de inibição do fator NFK-B por Vpu}

A inibição da ativação de NFk-B pelos diferentes alelos de Vpu foi analisada através de ensaio de luciferase. Brevemente, no primeiro dia células HEK 293 foram transfectadas por método de precipitação com fosfato de cálcio (descrito no "Item 3.4.1") com plasmídeos contendo os diferentes alelos da proteína viral Vpu (pCG-GFPaleloVpu) ou com o vetor vazio como controle (pCG-GFP), passadas 8 horas o meio DMEM em que as células se encontravam na transfecção foi trocado por DMEM fresco, no segundo dia pós transfecção pela manhã as células foram estimuladas com o indutor da ativação do NFK-B, o fator de necrose tumoral- NF- $\alpha$, na concentração final de 30 $\mathrm{ng} / \mathrm{ml}$ e incubadas novamente à $37 \mathrm{C}^{\circ} \mathrm{em} 5 \%$ de $\mathrm{CO}_{2}$. Passadas 8 horas as células foram lisadas, transferidas para placas "96 Flat Bottom White Polystyrol LumiNunc FluoroNunc" e a atividade luciferase determinada usando o kit Dual Luciferase Assay. Finalmente, a Unidade Relativa de Luminescência foi avaliada utilizando Tecan. 


\section{Capítulo 4. Resultados e Discussão}




\subsection{Sequenciamento e alinhamento dos diferentes alelos do gene Vpu}

Os diferentes alelos do gene Vpu clonados no vetor pCG-6His-IRES-GFP derivados de diferentes subtipos de HIV (B, C e F) e as variantes recombinantes BF (cedidos gentilmente pelo Dr. Mauricio Carobene da Faculdade de Medicina da Universidade de Buenos Aires) foram sequenciados e posteriormente alinhados com a sequência consenso do vírus selvagem subtipo B - NL4.3, utilizando o programa Bioedit 7.0.9 (2007) [307] por meio do algoritmo ClustalW [308]. Os diferentes alelos do gene vpu presentes nos recombinantes BF revelaram uma alta conservação no padrão de recombinação (Figura 4 A). Este padrão foi semelhante ao observado na recombinante BF, típico CRF12_BF, disponível no banco de dados no endereço eletrônico dos Los Alamos http://www.hiv.lanl.gov/content/sequence, que apresenta a sequência do subtipo B no domínio de transmembrana e na $\alpha$-hélice I, e a sequência do subtipo F1 na $\alpha$ - hélice II (Figura 4 B).

A

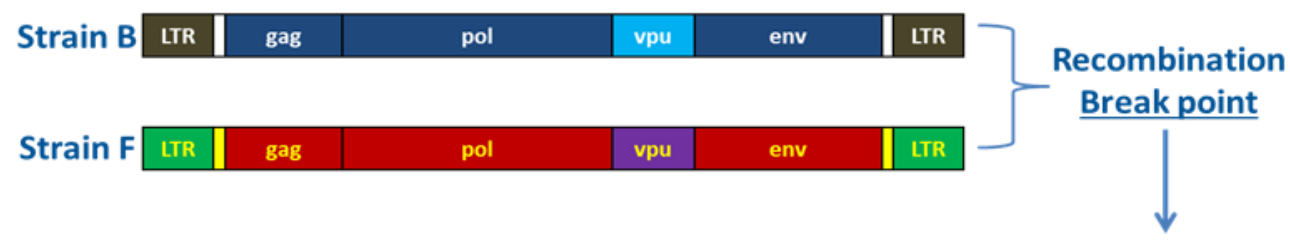

\begin{tabular}{l|l||l|l|l|l||l}
\cline { 2 - 5 } Strain BF & LTR & gag & pol & vpu & env & LTR \\
\hline
\end{tabular}

B Dominio de Transmembrana

Dominio Citoplasmatico

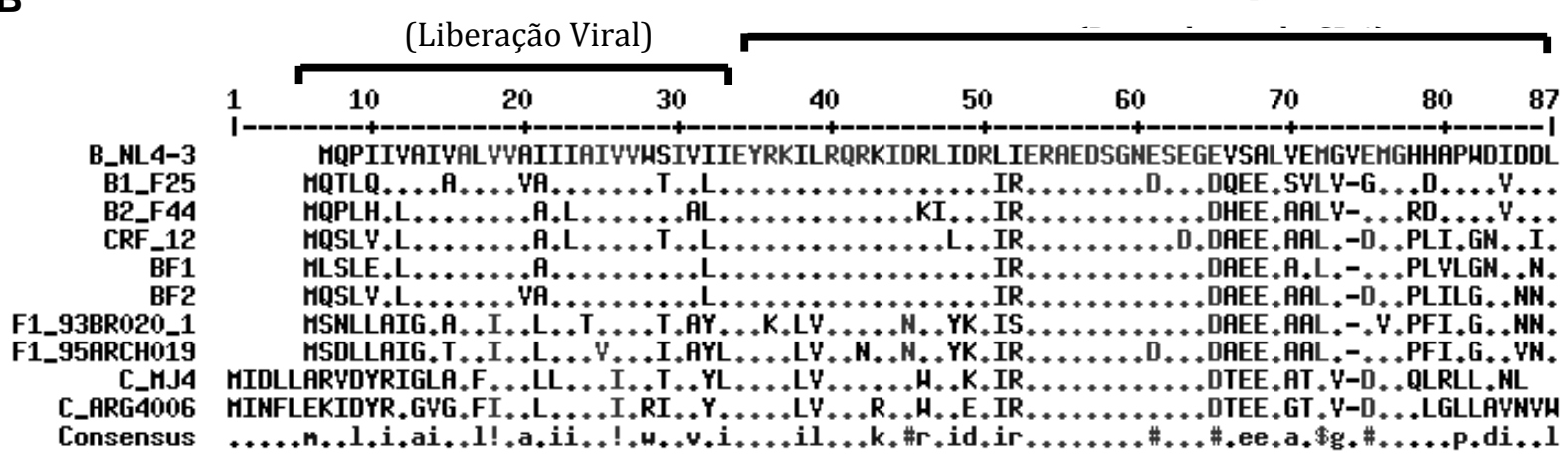

Figura 4.1. Alinhamento das sequências de aminoácidos das cepas B, C, F e os recombinantes BF. A. Desenho esquemático do sitio de recombinação do gene vpu entre cepas do subtipo B e F. B. Alinhamento das sequências de aminoácidos das cepas B, C, F e os recombinante BF. Os diferentes alelos da proteína viral Vpu clonados no vetor pCG foram sequenciados e a sequencia de aminoácidos correspondente foram alinhadas com a sequência consenso do vírus selvagem do subtipo B - NL4.3 do HIV-1. Similaridades nas sequencias de aminoácidos são indicadas por pontos e as diferenças são indicadas com a letra do aminoácido correspondentes. 
Estudos prévios mostraram um aumento da liberação de partículas virais por parte dos recombinantes $\mathrm{BF}$ quando comparado com uma variante selvagem do subtipo B em células que expressam Bst-2. Adicionalmente ensaios de competição "in vitro" sugeriram que essa diferença na produção viral poderia representar uma vantagem em termos de capacidade replicativa e adaptação viral [288].

\subsection{Construção de vetores de expressão de proteínas de fusão.}

Com objetivo de avaliar os níveis de interação entre os diferentes alelos de Vpu e as proteínas celulares por ensaios de FRET, os diferentes alelos de Vpu foram também clonados no vetor de expressão pEYFP e as proteínas celulares CD4 e Bst- 2 no vetor de expressão pECFP. As diferentes cepas de referencia, isolados primários e seus respectivos recombinates encontram-se descritos na tabela 1.

\begin{tabular}{|c|c|}
\hline Subtipo & Cepa/Isolado \\
\hline \multirow{3}{*}{ B } & $\underline{\text { NL4.3 }}$ \\
& B1 \\
B2 \\
\hline C & $\underline{\text { C }}$ \\
& MJ4 \\
\hline F1 & $\underline{\text { 93BR020.1 }}$ \\
\hline \multirow{2}{*}{ BF } & $\underline{\text { FR1 }}$ \\
& BF1 BFlike \\
& BF2 \\
\hline
\end{tabular}

Tabela4.1. Alelos de Vpu e suas cepas primárias. Lista dos alelos de Vpu correspondentes as cepas de referencia (sublinhadoa), isolados primários/parentais e isolados recombinantes foram clonados nos vetores pEYFP e pCG-Vpu-6His-IRES-GFP. 


\subsection{Caracterização da expressão dos isolados e recombinantes da proteína Vpu}

Após clonagem a expressão dos diferentes isolados e recombinantes foi confirmada por "imunobloting" em lisados de células 293T transfectadas com os diferentes vetores e utilizando anticorpos especificos para a calda de Histidina e a proteína YFP (como descrito em Materiais e Métodos) (Figura 5A). Adicionalmente a expressão dos vetores foi também confirmada por citometria de fluxo - FACS mediante a determinação dos níveis de fluorescência GFP (Figura 5B). Dessa forma foi possível observar altos níveis de expressão dos diferentes alelos de Vpu confirmando a eficiência de expressão em partículas virias.

A

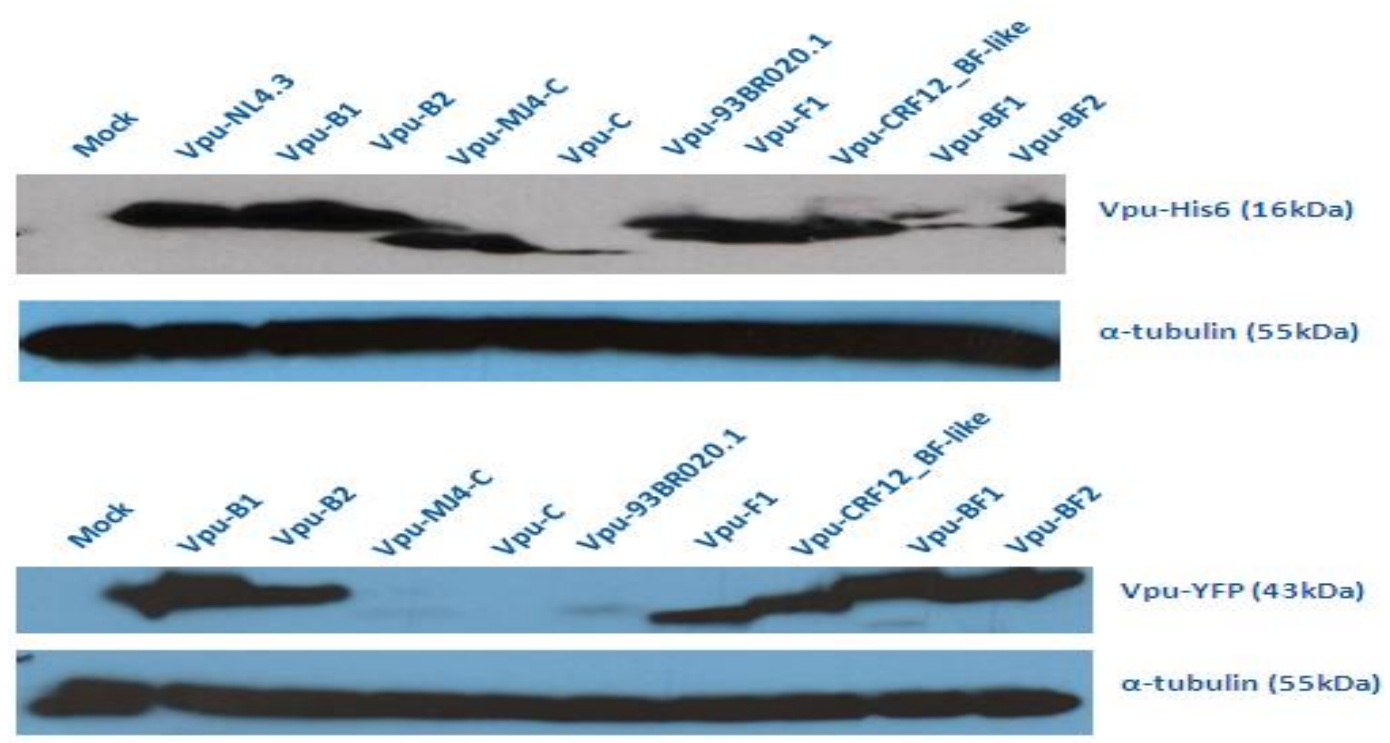

B

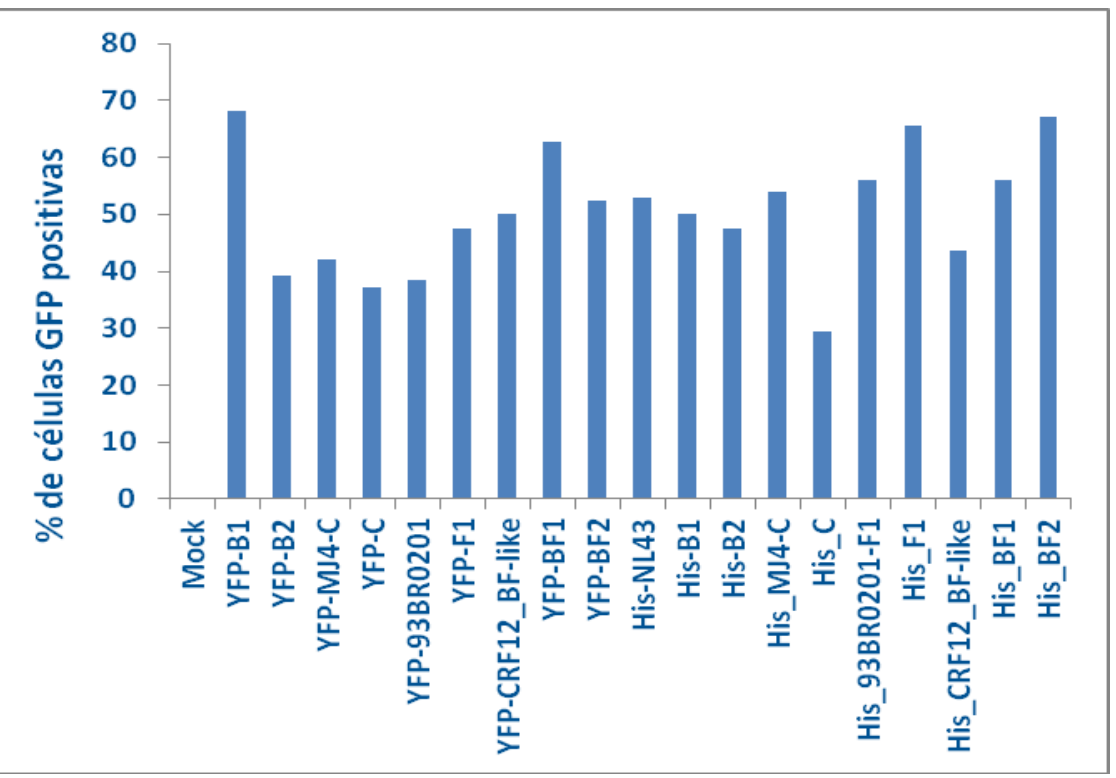


Figura 4.2. Caracterização da expressão dos isolados e recombinantes da proteína Vpu. A - expressão da expressão dos diferentes e isolados e recombinantes de Vpu clonados nos diferentes vetores foi confirmada por immunobloting de lisados provenientes de células 293T transfectadas com os diferentes vetores lentivirais, usando anticorpos específicos. B - A expressão da expressão dos diferentes e isolados e recombinates de Vpu foi também confirmada mediante medição dos níveis de expressão da proteína fluorescente GFP por citometria de fluxo -FACS.

\subsection{Caracterização da interação das proteínas celulares CD4 e Bst-2 com os isolados primeiros e recombinantes da proteína $V p u$}

Com o intuito de determinar o nível de interação entre CD4, Bst-2 e os diferentes isolados primeiros e recombinantes da proteína Vpu, foram realizados ensaios de FRET entre as proteínas celulares fusionadas a proteína fluorescente CFP e os diferentes isolados de Vpu fusionados a proteína fluorescente YFP.

Como descrito anteriormente células 293T foram co-transfectadas com os vetores de expressão e após 36 horas a interação entre as proteínas celulares e os diferentes alelos da proteína Vpu foi analisada por FACS/FRET.

A figura 7 mostra os diferentes níveis de interação detectados entre cada isolado de Vpu e a proteína CD4 expressos como porcentagem de interação. Foi verificado um baixo nível de interação entre CD4 e a cepa e isolado de Vpu do subtipo C (MJ4), assim como com o isolado 93BR020.1 do subtipo F1. Estes resultados estão de acordo ao descrito na literatura [309]. Já as cepas dos subtipos B e F e recombinantes BF apresentaram similares níveis de interação.

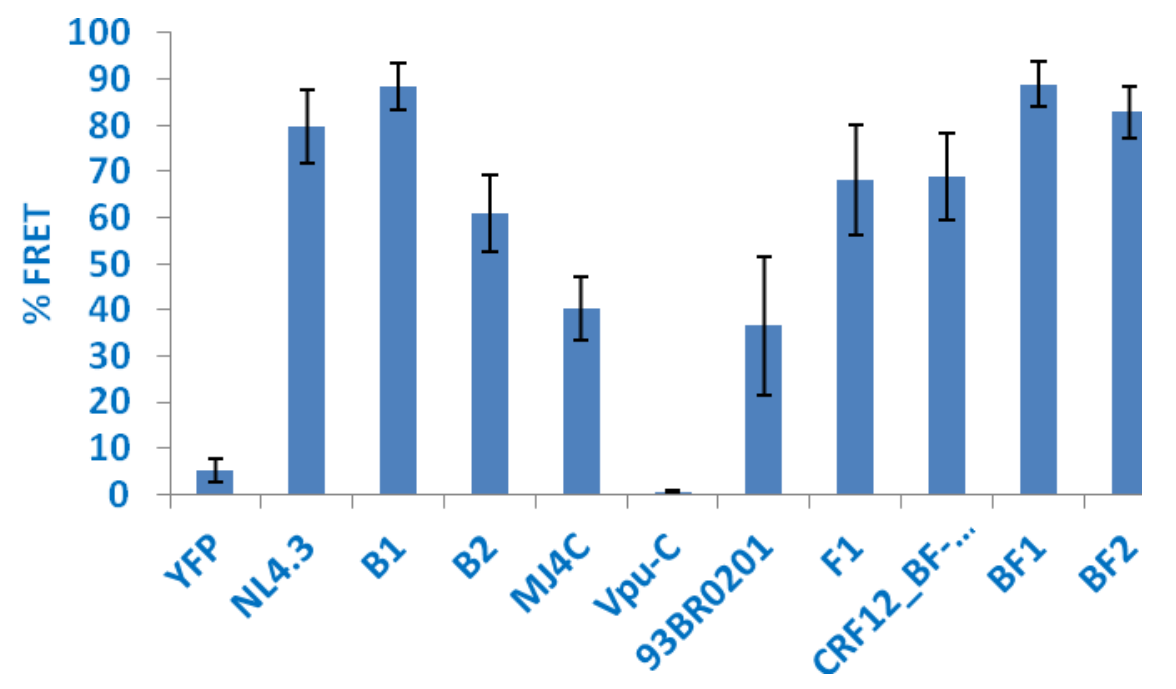


Figura 4.3. Interação entre CD4 e isolados da proteína viral Vpu. Os níveis de interação direta entre a proteína celular CD4 e os diferentes alelos de Vpu foram determinados por FRET, mediante co-transfecção em células $293 \mathrm{~T}$ com os diferentes vetores de fusão YFP (Vpu) e CFP (CD4).

Quando avaliada a interação dos diferentes isolados de Vpu com a proteína Bst-2, foi possível observar novamente uma baixa ou nula interação com a cepa do subtipo $\mathrm{C}$ e seu isolado primário, assim como o do subtipo F1. Curiosamente a cepa de referência CRF12_BF like e os recombinantes BF (BF1 e 2) apresentaram níveis de interação superiores aos observados com as cepas de referencia e seus parentais do subtipo B (Figura 8). Este último resultado, seria a princípio, foi um indicativo de uma provável maior modulação do inibidor celular da liberação viral por parte destes recombinantes.

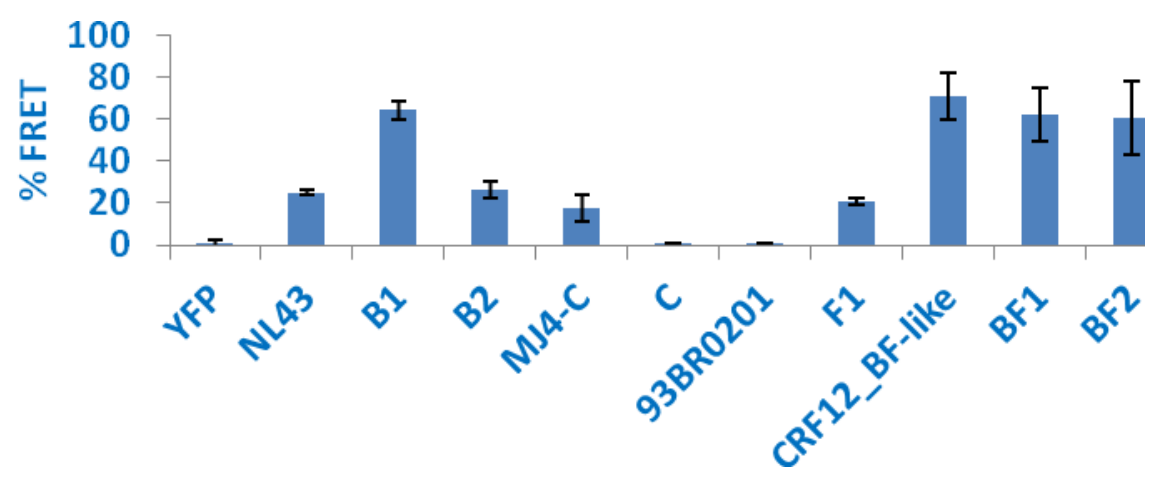

Figura 4.4. Interação entre Bst-2 e a proteína Vpu. Os níveis de interação direta entre a proteína celular Bst-2 e os diferentes alelos de Vpu foram determinados por FRET, mediante co-transfecção em células 293T com os diferentes vetores de fusão YFP (Vpu) e CFP (bst-2).

\subsection{Determinação dos níveis de degradação de CD4 e Bst-2 pelos diferentes alelos de $\mathrm{Vpu}$}

Com o objetivo de avaliar a relevância fisiológica das interações detectadas de CD4 com os diferentes alelos de $\mathrm{Vpu}$, células SupT-1 foram eletroporadas com vetores codificando os diferentes alelos de Vpu e 36 hs depois os níveis de expressão de CD4 foram avaliados por FACS usando anticorpo anti-CD4-APC em células GFP positivas (Figura 9). Os maiores níveis de modulação de CD4 foram detectados com a cepa NL43 do subtipo B e seus isolados B1 e B2, assim como pela cepa de referencia do subtipo F e os recombinantes BF. Já os alelos de Vpu do subtipo C mostraram uma pobre capacidade de degradar CD4. Estes últimos resultados vem a confirmar resultados prévios obtidos com este subtipo víral [266, 274, 309-311]. 


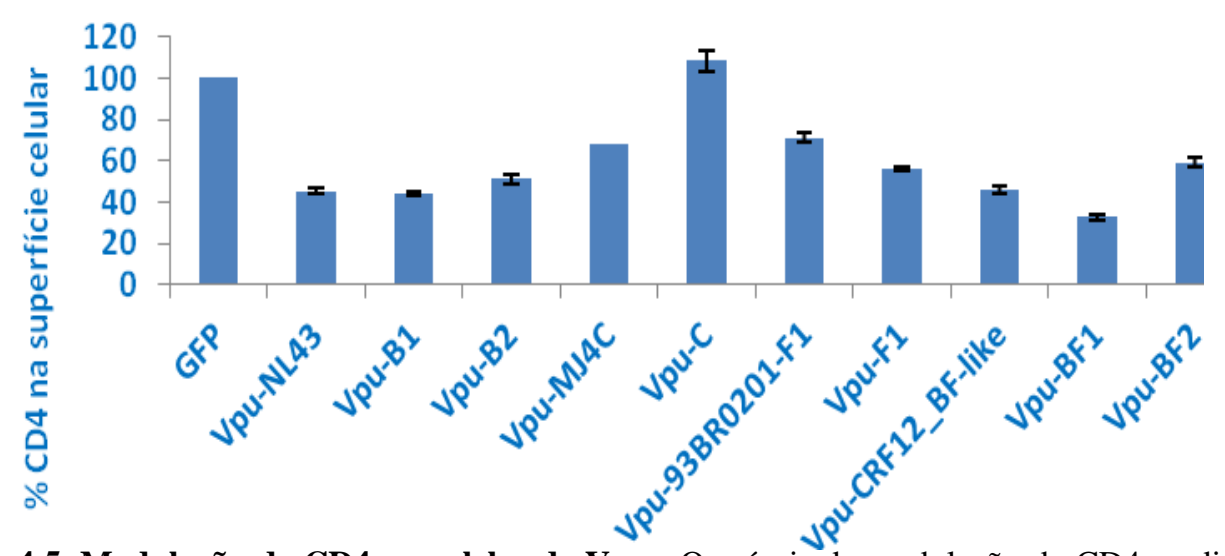

Figura 4.5. Modulação de CD4 por alelos de Vpu. Os níveis da modulação de CD4 mediado pelos diferentes isolados de Vpu foram determinados em células SupT-1 eletroporadas com vetores pCG-GFP específicos para cada um dos diferentes alelos. Os níveis de CD4 na superfície celular foram avaliados por Citometria de Fluxo, após marcação com anticorpos anti-CD4-APC.

Já os níveis de expressão da proteína Bst-2 na presencia dos diferentes alelos de Vpu foram avaliados em células Hela, uma vez que esta linha celular apresenta altos níveis de expressão deste inibidor viral. Desta forma foi possível observar novamente uma menor capacidade da cepa do subtipo C e o isolado 93BR020.1 do subtipo F1 de diminuir a expressão desta proteína na superfície celular. Estes resultados correlacionaram fortemente com os baixos níveis de interação detectados por FRET (Figura 10). Entretanto, os maiores níveis de interação observados pelos recombinantes não se traduziram em maiores níveis de diminuição da expressão desta proteína celular, quando comparados aos níveis de modulação observados pelo isolados do subtipo B. Uma possível explicação pra esta falta de correlação seria que a proteína viral Vpu exerceria seus efeitos não tão só mediante degradação de Bst-2, com o descrito em [309], mas também pela retenção da proteína celular Bst-2 no trans golgi. Este mecanismo já foi claramente mostrado na inibição da expressão do receptor NTB-A em células NK por esta mesma proteína viral [274].

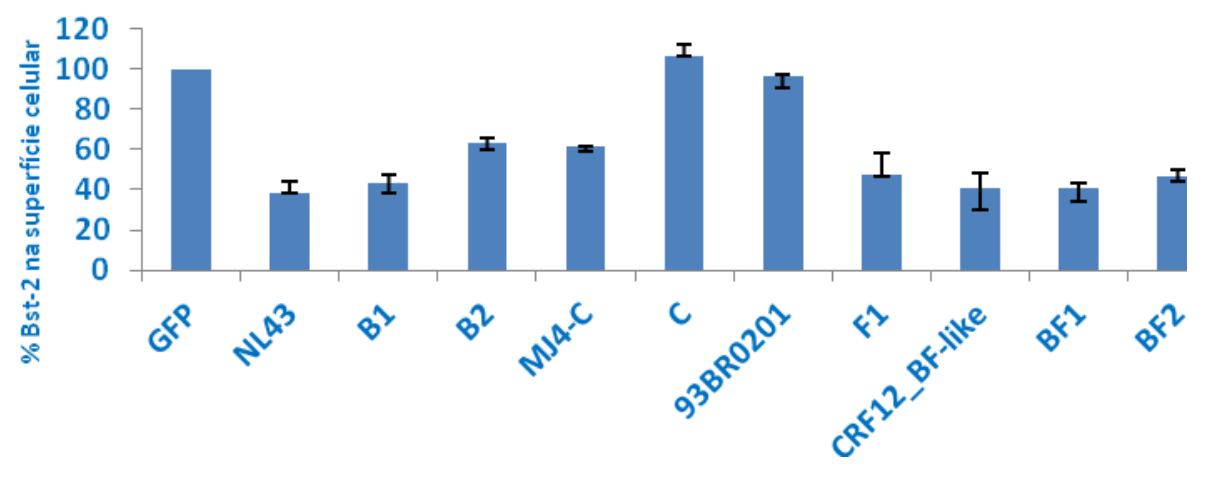


Figura 4.6. Modulação de Bst-2 por isolados de Vpu. Os níveis da modulação de Bst-2 pelos diferentes alelos de Vpu foram determinados em células Hela transfectadas com vetores pCG-GFP específicos para cada um dos diferentes alelos. Os níveis de Bst-2 na superfície celular foram avaliados por Citometria de Fluxo, após marcação com anticorpos anti-Bst2-PE.

\subsection{Determinação dos níveis de infecção induzidos pelos diferentes alelos de Vpu.}

Com o intuito de avaliar a relevância fisiológica da expressão dos recombinantes e seus isolados parentais quanto à infectividade como uma medida indireta da liberação viral, foram utilizadas células indicadoras de infecção Hela-RIG. Brevemente, células $293 \mathrm{~T}$ foram co-transfectadas com provirus $\mathrm{pBR} . \mathrm{NL} 43 / \Delta \mathrm{Nef} / \Delta \mathrm{Vpu}$ e os diferentes alelos de Vpu clonados no vetor pCG-GFP e o vetor pCG-Bst2. 36 hs depois os sobrenadantes foram recolhidos e utilizados para infectar células Hela-RIG. 48hs depois os níveis de infecção foram avaliados pela determinação dos níveis de fluorescência vermelha, dsRED [306].

Como mostrado em experimentos anteriores os isolados do suptipo C e F1 mostraram baixos níveis de infecciosidade. Curiosamente foi possível observar maiores índices de infecção pelos recombinantes BF quando comparado aos níveis observados pelos seus parentais (B1, B2 e F1). Estes maiores níveis de infecciosidade podem refletir maiores níveis de liberação viral, já que não foi possível medir os níveis de p24 no sobrenadante.

Estes dados sugerem fortemente que a maior interação por parte destes recombinantes com Bst-2, detectada pelos ensaios de FRET, podem ser o fator responsável pela maior infeciosidade viral observada. Por outro lado reforçam a ideia que a proteína Vpu exerceria seu efeito inibitório no bloqueio da liberação viral por meio de dois mecanismos; favorecendo a internalização de Bst-2 da superfície celular e retendo esta molécula no trans-golgi. Neste contexto os isolados recombinantes possuíram uma maior capacidade de reter Bst-2 no trans golgi que seus parentais.

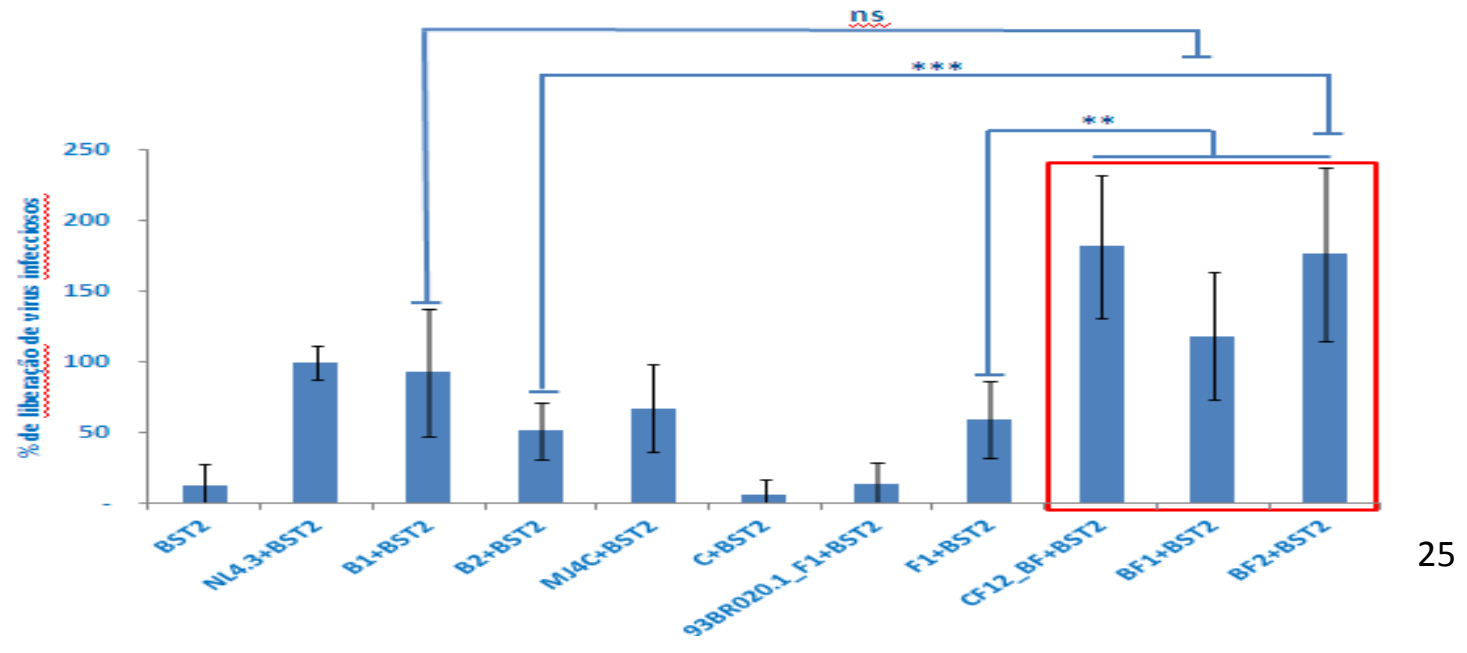


Figura 4.7. Nivies de infecção de partículas virias produzidas na presença de diferentes isolados de Vpu. Os níveis de infeciosidade das partículas virais, produzidas em células $293 \mathrm{~T}$ em presença dos diferentes alelos de Vpu forma comparados por ensaios de infecção utilizando as células indicadoras Hela-RIG [306]. O nível relativo de infecção estão representados comparativamente.

\subsection{Determinação dos níveis de inibição do fator de trarnscrição NFK-B induzidos pelos diferentes isolados de Vpu.}

Finalmente foram avaliados os níveis de bloqueio da ativação do fator de transcrição NFk-B pelos diferentes alelos de Vpu. Brevemente, células 293-NFK-B (que expressam constitutivamente o NFk-B/ IkB e o gene "repórter" da proteína lucifearse sobre o controle da expressão dos genes rev/tat, foram transfectadas com vetores pCGHis-GFP expressando os diferentes alelos de Vpu. Após 24 hs foi adicionado TNF- $\alpha$, indutor da atividade do fator NFk-B e 6 hs após os níveis de ativação do NFK-B foram determinados pela intensidade de expressão do gene "repórter" da proteína luciferase (como descrito em "Materiais e Métodos" deste capítulo).

Quando comparados os níveis de inibição da ativação deste fator de transcrição foi possível observar que o recombinante BF1 apresentou um nível de ativação aproximadamente 4 vezes maior que seu parental. Entretanto não foi observada nenhuma diferença significativa entre o outro recombinante e seu parental.

Dentro desde contexto, estes resultados sugerem que ao menos no caso do recombinante BF1, a perda da capacidade de inibir a ativação do NFK-B poderia estar relacionada a uma maior sobrevida da célula hospedeira e consequentemente a uma maior replicação e infectividade viral. Esta propriedade apresentada por este recombinante poderia favorecer sua propagação.

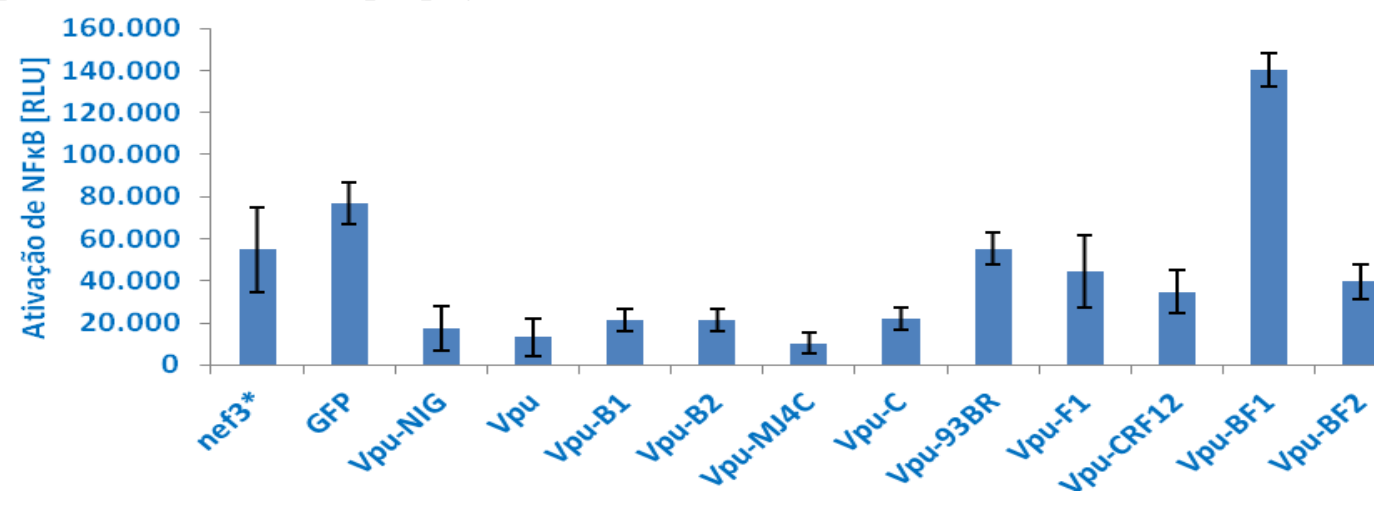

Figura 4.8. Níveis de inibição do NFK-B por isolados de Vpu. Células HEK 293 NFkB, contendo o gene para expressão de luciferase com promotor CMV, foram transfectadas com vetores pCG-His-GFP 
expressando os diferentes alelos de Vpu. 36 horas após transfecção as células foram lisadas e por ensaios de luciferase foi quantificada a Unidade Relativa de Luz (RLU).

O bloqueio da ativação deste fator transcricional se dá pelo sequestro da proteína $\beta$-TrCP, importante componente do complexo proteassômico, e dessa forma evitando a degradação do inibidor do fator NFK-B a proteína IkB. A inibição da ativação do NFK-B levaria à inibição de componentes da família das proteínas anti-poptotica Bcl-2 e do complexo de proteínas TNF-R $[312,313]$ e por outro lado, à ativação da caspase 3 e consequentemente à morte celular. Dessa forma $\mathrm{Vpu}$, ao igual que outras proteínas do HIV-1, tais como Nef, Tat, Vpr e Env, induziria apoptose de células infectadas e não infectadas. Recentes estudos têm sugerido que a ativação do sistema imune induzida pela infeção poderia facilitar a replicação viral e a prejudicar a função dos LTCD4+, levando a morte dos mesmos [314, 315]. Entretanto não se sabe ainda se a apoptose induzida por Vpu e as outras proteínas virais, nas células infectadas está associada a patogênese do HIV.

Dois estudos recentes revelam que a inibição de Bst2 por Vpu exerceria adicionalmente outra função não menos importante, permitindo que as células infectadas escapem da resposta imune de citotoxicidade celular anticorpo dependente, conhecida como ADCC [316] [317]. Foi observado que na ausência de Vpu as células infectadas apresentaram até cinco vezes maior expressão da glicoproteína Env na superfície celular e se mostraram até 60 vezes mais sensíveis à ADCC por células "Natural killer" (NK) mediada principalmente pela sinalização através do receptor Fc $\gamma$ RIIIa, e a consequente liberação de grânulos líticos nas células alvo opsonizadas com anticorpos.

Em resumo estes estudos sugerem fortemente que a maior capacidade apresentada pelos recombinantes $\mathrm{BF}$ em inibir a proteína celular Bst2 pode ser um fator crítico não tão só aumento de infectividade e liberação das partículas virias, como também na inibição da destruição das células infectadas pelo sistema imune de pacientes infectados por estas variantes. Acreditamos que a maior eficiência nestas funções apresentadas por estes recombinantes, podem conferir vantagens evolutivas auxiliando na propagação destas variantes na América do Sul. 


\section{Capítulo 5. Conclusões e Perspectivas}




\subsection{Conclusões}

As principais conclusões deste trabalho são resumidas a seguir:

- Os recombinantes BF de Vpu circulantes na Argentina e seus parentais interagem e degradam eficientemente o receptor viral CD4;

- Embora os recombinantes BF apresentem uma maior interação com Bst-2 quando comparado seus parentais, estes não se mostraram mais eficientes na diminuição da expressão desta proteína da superfície celular;

- Os recombinantes BF se mostraram mais eficientes na indução de infecciosidade entretanto não foi possível determinar o exato mecanismo envolvido;

- Quanto a inibição da ativação do fator de transcrição NFk-B, todos os isolados estudados se mostraram eficientes nesta função exceto o isolado recombinante BF1, o que poderia ser um fator importante na maior replicação e infectividade viral observada nas amostras clinicas carregando este recombinante;

- A maior capacidade de interação com Bst-2 por parte dos recombinantes BF poderia explicar, ao menos em parte, a maior infectividade e consequentemente maior capacidade de propagação destes recombinantes na américa do sul

\subsection{Perspectivas}

Em base aos dados obtidos neste trabalho nos traçamos os seguintes objetivos:

- Avaliar outras funciones biológicas dos recombinantes BF como a capacidade de degradar os receptores CD1d, NKT e NTB-A;

- Investigar o mecanismo pelo qual os recombinantes BF induzem uma maior infectividade viral apesar de não apresentar uma maior eficiência na modulação de Bst-2.

- Avaliar comparativamente a capacidade de vírus carregando os diferentes alelos de Vpu de induzir a resposta imune citotóxica anticorpo dependente (ADCC). 
Referências Bibliográficas:

1. Prusiner, S.B., Historical essay. Discovering the cause of AIDS. Science, 2002. 298(5599): p. 1726.

2. Montagnier, L., Historical essay. A history of HIV discovery. Science, 2002. 298(5599): p. 1727-8.

3. Montagnier L, C.J., Barré-Sinoussi F, Chamaret S, Gruest J, Nugeyre M, Rey F, Dauguet C, Axler-Blin C, Brun-Vezinet F, Rouzi- oux C, Saimot GA, Rozenbaum W, Gluckman JC, Klatzman D, Vilmer E, Griscelli C, FoyerGazengel C, Brunet JB, A new human T-lympho- tropic retrovirus: Characterization and possible role in lymphadenopathy and acquired immune deficiency syndromes, ed. C.S.H.-b. Laboratory. 1984, New York.

4. Gallo, R.C., Historical essay. The early years of HIV/AIDS. Science, 2002. 298(5599): p. 1728-30.

5. Wigg, Vírus da imunodeficiência humana. Introdução à Virologia Humana, ed. G. Koogan. 2002, Rio de Janeiro.

6. Gallo, R.C. and L. Montagnier, Historical essay. Prospects for the future. Science, 2002. 298(5599): p. 1730-1.

7. Levy, J.A., HIV and the pathogenesis of AIDS. Washington DC, 1998.

8. Regenmortel, v., Virus Taxonomy. Seventh Report of International Comitte on Taxonomy of Viruses, ed. A. Press. 2000, San Diego: Elsevier.

9. Votteler, Human Immunodeficiency Viruses: Molecular Biology, in Desk Encyclopedia of General Virology, A. Press, Editor. 2008: San Diego.

10. UNAIDS, Global Report on the Global AIDS epidemic 2013, in GLOBAL REPORT. 2013.

11. Saúde, M.d., HIV e AIDS no Brasil. Boletim Epidemiológico DST/AIDS, 2013.

12. Prevention, C.f.D.C.a. 2013 [cited; Available from: www.cdc.gov. 
13. Dodds, J.P., et al., Increase in high risk sexual behaviour among homosexual men, London 1996-8: cross sectional, questionnaire study. BMJ, 2000. 320(7248): p. 1510-1.

14. Selik, R.M., S.Y. Chu, and J.W. Ward, Trends in infectious diseases and cancers among persons dying of HIV infection in the United States from 1987 to 1992. Ann Intern Med, 1995. 123(12): p. 933-6.

15. Younai, F.S., Oral HIV transmission. J Calif Dent Assoc, 2001. 29(2): p. 142-8.

16. Baba, T.W., et al., Infection and AIDS in adult macaques after nontraumatic oral exposure to cell-free SIV. Science, 1996. 272(5267): p. 1486-9.

17. Ruprecht, R.M., et al., Oral SIV, SHIV, and HIV type 1 infection. AIDS Res Hum Retroviruses, 1998. 14 Suppl 1: p. S97-103.

18. Quinn, T.C., Global burden of the HIV pandemic. Lancet, 1996. 348(9020): p. 99-106.

19. Wiktor, S.Z., E. Ekpini, and R.W. Nduati, Prevention of mother-to-child transmission of HIV-1 in Africa. AIDS, 1997. 11 Suppl B: p. S79-87.

20. UNAIDS, UNAIDS report on the global AIDS epidemic 2012. Global Report, 2012.

21. Saúde, M. 2011 [cited 2011.

22. Stevenson, M., HIV-1 pathogenesis. Nat Med, 2003. 9(7): p. 853-60.

23. Perreau, M., et al., Follicular helper T cells serve as the major CD4 T cell compartment for HIV-1 infection, replication, and production. J Exp Med, 2013. 210(1): p. 143-56.

24. Buchbinder, S.P., et al., Long-term HIV-1 infection without immunologic progression. AIDS, 1994. 8(8): p. 1123-8.

25. Lefrere, J.J., et al., Even individuals considered as long-term nonprogressors show biological signs of progression after 10 years of human immunodeficiency virus infection. Blood, 1997. 90(3): p. 1133-40.

26. Cao, Y., et al., Clinical evaluation of branched DNA signal amplification for quantifying HIV type 1 in human plasma. AIDS Res Hum Retroviruses, 1995. 11(3): p. 353-61. 
27. Walker, B.D. and X.G. Yu, Unravelling the mechanisms of durable control of HIV-1. Nat Rev Immunol, 2013. 13(7): p. 487-98.

28. Madec, Y., et al., Undetectable viremia without antiretroviral therapy in patients with HIV seroconversion: an uncommon phenomenon? Clin Infect Dis, 2005. 40(9): p. 1350-4.

29. Brantly, M., T. Nukiwa, and R.G. Crystal, Molecular basis of alpha-1antitrypsin deficiency. Am J Med, 1988. 84(6A): p. 13-31.

30. Goujard, C., et al., Spontaneous control of viral replication during primary HIV infection: when is "HIV controller" status established? Clin Infect Dis, 2009. 49(6): p. 982-6.

31. Crisp, H.C., et al., Successful treatment of severe pneumocystis pneumonia with clindamycin-primaquine in an HIV-negative patient. South Med J, 2009. 102(11): p. 1161-3.

32. Mandalia, S., et al., Are long-term non-progressors very slow progressors? Insights from the Chelsea and Westminster HIV cohort, 1988-2010. PLoS One. 7(2): p. e29844.

33. Yerly, S., et al., Transmission of antiretroviral-drug-resistant HIV-1 variants. Lancet, 1999. 354(9180): p. 729-33.

34. Furtado, M.R., et al., Persistence of HIV-1 transcription in peripheral-blood mononuclear cells in patients receiving potent antiretroviral therapy. $N$ Engl J Med, 1999. 340(21): p. 1614-22.

35. De Clercq, E., Antiviral drugs in current clinical use. J Clin Virol, 2004. 30(2): p. 115-33.

36. Dimmock NJ, E.A., Leppard KN, Introduction to modern virology. $6^{a}$ ed. 2007, Malden, EUA: Blackwell Publishing.

37. Janeway CA, T.P., Walport M, Shlomchik M., O sistema imune na saúde e na doença, in Imunobiologia. 2004, Artmed: São Paulo.

38. Flint, S.J.E., L.W.; Krug R.M.; Racaniello, V.R.; Skalka, A.M., Virology: Molecular Biology, Pathogenesis, and Control, ed. E.A. Press. 2004.

39. Carter, J.B.S., V.A., Virology : principles and applications, ed. J.W.S. Ltd. 2007, Cichester, Inglaterra. 
40. Larder, B.R., D.; Vella, S., HIV Resistance and Implications for Therapy, ed. M. Inc. Vol. $2^{a}$ ed. 2001, Atlanta.

41. Cann, A.J., Principles of Molecular Virology, ed. Elsevier. Vol. $4^{a}$ ed. 2005, Oxford.

42. Greene, W.C., The brightening future of HIV therapeutics, ed. N. Immunology. Vol. 5. 2004. p.867-71.

43. Malim, M.H., APOBEC proteins and intrinsic resistance to HIV-1 infection. Philos Trans R Soc Lond B Biol Sci, 2009. 364(1517): p. 675-87.

44. Göttlinger, H.G., HIV-1 Gag: a Molecular Machine Driving Viral Particle Assembly and Release, in HIV Sequence Compendium, F.B. Kuiken C, Hahn B, Marx P, McCutchan F, Mellors JW, Wolinsky S, Korber B., Editor. 2001, Theoretical Biology and Biophysics Group, Los Alamos National Laboratory.p. pp. 2-28.

45. Moore, J.P. and R.W. Doms, The entry of entry inhibitors: a fusion of science and medicine. Proc Natl Acad Sci U S A, 2003. 100(19): p. 10598-602.

46. Miller, R.J., et al., Human immunodeficiency virus and AIDS: insights from animal lentiviruses. J Virol, 2000. 74(16): p. 7187-95.

47. Kirchhoff, F., et al., Sequence variations in human immunodeficiency virus type 1 Nef are associated with different stages of disease. J Virol, 1999. 73(7): p. 5497-508.

48. Margottin, F., et al., A novel human WD protein, h-beta TrCp, that interacts with HIV-1 Vpu connects CD4 to the ER degradation pathway through an Fbox motif. Mol Cell, 1998. 1(4): p. 565-74.

49. Sheehy, A.M., N.C. Gaddis, and M.H. Malim, The antiretroviral enzyme APOBEC3G is degraded by the proteasome in response to HIV-1 Vif. Nat Med, 2003. 9(11): p. 1404-7.

50. Hrecka, K., et al., Lentiviral Vpr usurps Cul4-DDB1[VprBP] E3 ubiquitin ligase to modulate cell cycle. Proc Natl Acad Sci U S A, 2007. 104(28): p. 11778-83.

51. Schubert, U., et al., Identification of an ion channel activity of the Vpu transmembrane domain and its involvement in the regulation of virus release from HIV-1-infected cells. FEBS Lett, 1996. 398(1): p. 12-8. 
52. Neil, S.J., T. Zang, and P.D. Bieniasz, Tetherin inhibits retrovirus release and is antagonized by HIV-1 Vpu. Nature, 2008. 451(7177): p. 425-30.

53. Van Damme, $N$., et al., The interferon-induced protein BST-2 restricts HIV-1 release and is downregulated from the cell surface by the viral Vpu protein. Cell Host Microbe, 2008. 3(4): p. 245-52.

54. Andersen, J.L. and V. Planelles, The role of Vpr in HIV-1 pathogenesis. Curr HIV Res, 2005. 3(1): p. 43-51.

55. Le Rouzic, E. and S. Benichou, The Vpr protein from HIV-1: distinct roles along the viral life cycle. Retrovirology, 2005. 2: p. 11.

56. Holmes, R.K., et al., APOBEC3F can inhibit the accumulation of HIV-1 reverse transcription products in the absence of hypermutation. Comparisons with APOBEC3G. J Biol Chem, 2007. 282(4): p. 2587-95.

57. Soros, V.B., W. Yonemoto, and W.C. Greene, Newly synthesized APOBEC3G is incorporated into HIV virions, inhibited by HIV RNA, and subsequently activated by RNase H. PLoS Pathog, 2007. 3(2): p. e15.

58. Milich, L., B. Margolin, and R. Swanstrom, V3 loop of the human immunodeficiency virus type 1 Env protein: interpreting sequence variability. J Virol, 1993. 67(9): p. 5623-34.

59. Feng, Y., et al., HIV-1 entry cofactor: functional cDNA cloning of a seventransmembrane, G protein-coupled receptor. Science, 1996. 272(5263): p. 8727.

60. Clapham, P.R. and A. McKnight, Cell surface receptors, virus entry and tropism of primate lentiviruses. J Gen Virol, 2002. 83(Pt 8): p. 1809-29.

61. Spijkerman, I.J., et al., Lower prevalence and incidence of HIV-1 syncytiuminducing phenotype among injecting drug users compared with homosexual men. AIDS, 1995. 9(9): p. 1085-92.

62. Franke, E.K., H.E. Yuan, and J. Luban, Specific incorporation of cyclophilin A into HIV-1 virions. Nature, 1994. 372(6504): p. 359-62.

63. Schaeffer, E., R. Geleziunas, and W.C. Greene, Human immunodeficiency virus type 1 Nef functions at the level of virus entry by enhancing cytoplasmic delivery of virions. J Virol, 2001. 75(6): p. 2993-3000. 
64. Ohagen, A. and D. Gabuzda, Role of Vif in stability of the human immunodeficiency virus type 1 core. J Virol, 2000. 74(23): p. 11055-66.

65. Chen, H., S.Q. Wei, and A. Engelman, Multiple integrase functions are required to form the native structure of the human immunodeficiency virus type I intasome. J Biol Chem, 1999. 274(24): p. 17358-64.

66. Miller, M.D., C.M. Farnet, and F.D. Bushman, Human immunodeficiency virus type 1 preintegration complexes: studies of organization and composition. J Virol, 1997. 71(7): p. 5382-90.

67. Fackler, O.T., et al., Activation of Vav by Nef induces cytoskeletal rearrangements and downstream effector functions. Mol Cell, 1999. 3(6): p. 729-39.

68. Pulkkinen, K., et al., Nef associates with p21-activated kinase 2 in a p21GTPase-dependent dynamic activation complex within lipid rafts. J Virol, 2004. 78(23): p. 12773-80.

69. Bushman, F., A new cellular system opposing HIV infection: implications for gene transfer? Mol Ther, 2002. 6(4): p. 441-2.

70. Zennou, V., et al., HIV-1 genome nuclear import is mediated by a central DNA flap. Cell, 2000. 101(2): p. 173-85.

71. Lodish, H.B., A.; Matsuraida, P.; Kaiser, C.A.; Krieger, M.; Scott, M.P.; Zipursky, S.L. \& Darnell, J., Molecular Cell Biology. Vol. 6th. 2005, New York: WH Freeman and Company.

72. Yang, Z., et al., The 7SK small nuclear RNA inhibits the CDK9/cyclin T1 kinase to control transcription. Nature, 2001. 414(6861): p. 317-22.

73. Powell, D.M., et al., HIV Rev-dependent binding of SF2/ASF to the Rev response element: possible role in Rev-mediated inhibition of HIV RNA splicing. Proc Natl Acad Sci U S A, 1997. 94(3): p. 973-8.

74. Pornillos, O., et al., HIV Gag mimics the Tsg101-recruiting activity of the human Hrs protein. J Cell Biol, 2003. 162(3): p. 425-34.

75. Levy, J.A., Pathogenesis of human immunodeficiency virus infection. Microbiol Rev, 1993. 57(1): p. 183-289. 
76. Hammonds, J., et al., Gp120 stability on HIV-1 virions and Gag-Env pseudovirions is enhanced by an uncleaved Gag core. Virology, 2003. 314(2): p. 636-49.

77. Douek, D.C., et al., HIV preferentially infects HIV-specific CD4+ T cells. Nature, 2002. 417(6884): p. 95-8.

78. Chaudhuri, R., et al., Downregulation of CD4 by human immunodeficiency virus type 1 Nef is dependent on clathrin and involves direct interaction of Nef with the AP2 clathrin adaptor. J Virol, 2007. 81(8): p. 3877-90.

79. Appay, V., et al., Memory CD8+ T cells vary in differentiation phenotype in different persistent virus infections. Nat Med, 2002. 8(4): p. 379-85.

80. Iyer, S.B., et al., Quantitation of CD38 expression using QuantiBRITE beads. Cytometry, 1998. 33(2): p. 206-12.

81. Sereti, I., et al., In vivo expansion of CD4CD45RO-CD25 T cells expressing foxP3 in IL-2-treated HIV-infected patients. J Clin Invest, 2005. 115(7): p. 1839-47.

82. Emu, B., et al., Phenotypic, functional, and kinetic parameters associated with apparent $T$-cell control of human immunodeficiency virus replication in individuals with and without antiretroviral treatment. J Virol, 2005. 79(22): p. 14169-78.

83. Klatt, N.R., et al., Limited HIV infection of central memory and stem cell memory CD4+ T cells is associated with lack of progression in viremic individuals. PLoS Pathog. 10(8): p. e1004345.

84. Lapham, C.K., et al., Evidence for cell-surface association between fusin and the CD4-gp120 complex in human cell lines. Science, 1996. 274(5287): p. $602-$ 5.

85. Stevens, T.H. and M. Forgac, Structure, function and regulation of the vacuolar (H+)-ATPase. Annu Rev Cell Dev Biol, 1997. 13: p. 779-808.

86. Guy, B., et al., HIV F/3' orf encodes a phosphorylated GTP-binding protein resembling an oncogene product. Nature, 1987. 330(6145): p. 266-9.

87. Foster, J.L., et al., Specific suppression of human CD4 surface expression by Nef from the pathogenic simian immunodeficiency virus SIVmac239open. Virology, 1994. 201(2): p. 373-9. 
88. Cortes, M.J., F. Wong-Staal, and J. Lama, Cell surface CD4 interferes with the infectivity of HIV-1 particles released from T cells. J Biol Chem, 2002. 277(3): p. $1770-9$.

89. Coleman, S.H., J.R. Day, and J.C. Guatelli, The HIV-1 Nef protein as a target for antiretroviral therapy. Expert Opin Ther Targets, 2001. 5(1): p. 1-22.

90. Chen, B.K., R.T. Gandhi, and D. Baltimore, CD4 down-modulation during infection of human $T$ cells with human immunodeficiency virus type 1 involves independent activities of vpu, env, and nef. J Virol, 1996. 70(9): p. 6044-53.

91. Arganaraz, E.R., et al., Enhanced CD4 down-modulation by late stage HIV-1 nef alleles is associated with increased Env incorporation and viral replication. J Biol Chem, 2003. 278(36): p. 33912-9.

92. Harper, M.E., et al., Detection of lymphocytes expressing human Tlymphotropic virus type III in lymph nodes and peripheral blood from infected individuals by in situ hybridization. Proc Natl Acad Sci U S A, 1986. 83(3): p. 772-6.

93. Schwartz, O., et al., Human immunodeficiency virus type 1 Nef induces accumulation of CD4 in early endosomes. J Virol, 1995. 69(1): p. 528-33.

94. Mangasarian, A., et al., The HIV-1 Nef protein acts as a connector with sorting pathways in the Golgi and at the plasma membrane. Immunity, 1997. 6(1): p. 67-77.

95. Piguet, V., et al., Mechanism of Nef-induced CD4 endocytosis: Nef connects CD4 with the mu chain of adaptor complexes. EMBO J, 1998. 17(9): p. 247281.

96. Le Gall, S., et al., Nef interacts with the mu subunit of clathrin adaptor complexes and reveals a cryptic sorting signal in MHC I molecules. Immunity, 1998. 8(4): p. 483-95.

97. Craig, H.M., et al., Interactions of HIV-1 nef with the mu subunits of adaptor protein complexes 1, 2, and 3: role of the dileucine-based sorting motif. Virology, 2000. 271(1): p. 9-17.

98. Stevenson, M., et al., Envelope glycoprotein of HIV induces interference and cytolysis resistance in CD4+ cells: mechanism for persistence in AIDS. Cell, 1988. 53(3): p. 483-96. 
99. Geleziunas, R., S. Bour, and M.A. Wainberg, Cell surface down-modulation of CD4 after infection by HIV-1. FASEB J, 1994. 8(9): p. 593-600.

100. Cohen, E.A., et al., Identification of a protein encoded by the vpu gene of HIV1. Nature, 1988. 334(6182): p. 532-4.

101. Newell, M.K., et al., Death of mature T cells by separate ligation of CD4 and the T-cell receptor for antigen. Nature, 1990. 347(6290): p. 286-9.

102. Wassmer, P., et al., Role of the L3T4-antigen in T cell activation. II. Inhibition of $T$ cell activation by monoclonal anti-L3T4 antibodies in the absence of accessory cells. J Immunol, 1985. 135(4): p. 2237-42.

103. Tobiume, M., et al., Inefficient enhancement of viral infectivity and CD4 downregulation by human immunodeficiency virus type 1 Nef from Japanese long-term nonprogressors. J Virol, 2002. 76(12): p. 5959-65.

104. Potash, M.J. and D.J. Volsky, Viral interference in HIV-1 infected cells. Rev Med Virol, 1998. 8(4): p. 203-211.

105. Benson, R.E., et al., Downregulation of cell-surface CD4 expression by simian immunodeficiency virus Nef prevents viral super infection. J Exp Med, 1993. 177(6): p. 1561-6.

106. Bour, S., C. Perrin, and K. Strebel, Cell surface CD4 inhibits HIV-1 particle release by interfering with Vpu activity. J Biol Chem, 1999. 274(47): p. 33800-6.

107. Lama, J., A. Mangasarian, and D. Trono, Cell-surface expression of CD4 reduces HIV-1 infectivity by blocking Env incorporation in a Nef- and Vpuinhibitable manner. Curr Biol, 1999. 9(12): p. 622-31.

108. Marshall, W.L., et al., High level of surface CD4 prevents stable human immunodeficiency virus infection of T-cell transfectants. J Virol, 1992. 66(9): p. 5492-9.

109. Geyer, M., O.T. Fackler, and B.M. Peterlin, Structure--function relationships in HIV-1 Nef. EMBO Rep, 2001. 2(7): p. 580-5.

110. Saksela, K., G. Cheng, and D. Baltimore, Proline-rich (PxxP) motifs in HIV-1 Nef bind to SH3 domains of a subset of Src kinases and are required for the enhanced growth of Nef+ viruses but not for down-regulation of CD4. EMBO J, 1995. 14(3): p. 484-91. 
111. Arold, S.T. and A.S. Baur, Dynamic Nef and Nef dynamics: how structure could explain the complex activities of this small HIV protein. Trends Biochem Sci, 2001. 26(6): p. 356-63.

112. Geyer, M., et al., Structure of the anchor-domain of myristoylated and nonmyristoylated HIV-1 Nef protein. J Mol Biol, 1999. 289(1): p. 123-38.

113. Geyer, M. and B.M. Peterlin, Domain assembly, surface accessibility and sequence conservation in full length HIV-1 Nef. FEBS Lett, 2001. 496(2-3): p. 91-5.

114. Kestler, H.W., 3rd, et al., Importance of the nef gene for maintenance of high virus loads and for development of AIDS. Cell, 1991. 65(4): p. 651-62.

115. Kirchhoff, $F$., et al., Brief report: absence of intact nef sequences in a long-term survivor with nonprogressive HIV-1 infection. $N$ Engl J Med, 1995. 332(4): p. 228-32.

116. Deacon, N.J., et al., Genomic structure of an attenuated quasi species of HIV-1 from a blood transfusion donor and recipients. Science, 1995. 270(5238): p. 988-91.

117. Miller, M.D., et al., The human immunodeficiency virus-1 nef gene product: a positive factor for viral infection and replication in primary lymphocytes and macrophages. J Exp Med, 1994. 179(1): p. 101-13.

118. Swigut, T., N. Shohdy, and J. Skowronski, Mechanism for down-regulation of CD28 by Nef. EMBO J, 2001. 20(7): p. 1593-604.

119. Aiken, C., et al., Nef induces CD4 endocytosis: requirement for a critical dileucine motif in the membrane-proximal CD4 cytoplasmic domain. Cell, 1994. 76(5): p. 853-64.

120. Schwartz, O., et al., Endocytosis of major histocompatibility complex class I molecules is induced by the HIV-1 Nef protein. Nat Med, 1996. 2(3): p. 338-42.

121. Stumptner-Cuvelette, P., et al., HIV-1 Nef impairs MHC class II antigen presentation and surface expression. Proc Natl Acad Sci U S A, 2001. 98(21): p. 12144-9.

122. Hrecka, K., et al., Nef proteins from diverse groups of primate lentiviruses downmodulate CXCR4 to inhibit migration to the chemokine stromal derived factor 1. J Virol, 2005. 79(16): p. 10650-9. 
123. Greenberg, M.E., et al., Co-localization of HIV-1 Nef with the AP-2 adaptor protein complex correlates with Nef-induced CD4 down-regulation. EMBO J, 1997. 16(23): p. 6964-76.

124. Bresnahan, P.A., W. Yonemoto, and W.C. Greene, Cutting edge: SIV Nef protein utilizes both leucine- and tyrosine-based protein sorting pathways for down-regulation of CD4. J Immunol, 1999. 163(6): p. 2977-81.

125. Bresnahan, P.A., et al., A dileucine motif in HIV-1 Nef acts as an internalization signal for CD4 downregulation and binds the AP-1 clathrin adaptor. Curr Biol, 1998. 8(22): p. 1235-8.

126. Geyer, M., et al., Subunit $H$ of the V-ATPase binds to the medium chain of adaptor protein complex 2 and connects Nef to the endocytic machinery. J Biol Chem, 2002. 277(32): p. 28521-9.

127. Erdtmann, L., et al., Two independent regions of HIV-1 Nef are required for connection with the endocytic pathway through binding to the mu 1 chain of AP1 complex. Traffic, 2000. 1(11): p. 871-83.

128. Liu, L.X., et al., Binding of HIV-1 Nef to a novel thioesterase enzyme correlates with Nef-mediated CD4 down-regulation. J Biol Chem, 1997. 272(21): p. 13779-85.

129. Cohen, G.B., et al., The human thioesterase II protein binds to a site on HIV-1 Nef critical for CD4 down-regulation. J Biol Chem, 2000. 275(30): p. 23097105.

130. Watanabe, $H$., et al., A novel acyl-CoA thioesterase enhances its enzymatic activity by direct binding with HIV Nef. Biochem Biophys Res Commun, 1997. 238(1): p. 234-9.

131. Pizzato, M., et al., Dynamin 2 is required for the enhancement of HIV-1 infectivity by Nef. Proc Natl Acad Sci U S A, 2007. 104(16): p. 6812-7.

132. Bentham, M., S. Mazaleyrat, and M. Harris, The di-leucine motif in the cytoplasmic tail of CD4 is not required for binding to human immunodeficiency virus type 1 Nef, but is critical for CD4 down-modulation. J Gen Virol, 2003. 84(Pt 10): p. 2705-13.

133. Cheng-Mayer, C., et al., Differential effects of nef on HIV replication: implications for viral pathogenesis in the host. Science, 1989. 246(4937): $p$. 1629-32. 
134. Grzesiek, S., et al., The solution structure of HIV-1 Nef reveals an unexpected fold and permits delineation of the binding surface for the SH3 domain of Hck tyrosine protein kinase. Nat Struct Biol, 1996. 3(4): p. 340-5.

135. Gu, F. and J. Gruenberg, ARF1 regulates $p H-d e p e n d e n t$ COP functions in the early endocytic pathway. J Biol Chem, 2000. 275(11): p. 8154-60.

136. Jin, Y.J., et al., HIV Nef-mediated CD4 down-regulation is adaptor protein complex 2 dependent. J Immunol, 2005. 175(5): p. 3157-64.

137. Piguet, V., et al., HIV-1 Nef protein binds to the cellular protein PACS-1 to downregulate class I major histocompatibility complexes. Nat Cell Biol, 2000. 2(3): p. 163-7.

138. Preusser, A., et al., Direct in vitro binding of full-length human immunodeficiency virus type 1 Nef protein to CD4 cytoplasmic domain. J Virol, 2001. 75(8): p. 3960-4.

139. Rossi, F., A. Gallina, and G. Milanesi, Nef-CD4 physical interaction sensed with the yeast two-hybrid system. Virology, 1996. 217(1): p. 397-403.

140. Cohen, G.B., et al., The selective downregulation of class I major histocompatibility complex proteins by HIV-1 protects HIV-infected cells from NK cells. Immunity, 1999. 10(6): p. 661-71.

141. Craig, H.M., et al., Analysis of the SH3-binding region of HIV-1 nef: partial functional defects introduced by mutations in the polyproline helix and the hydrophobic pocket. Virology, 1999. 262(1): p. 55-63.

142. Eichholtz, T., et al., Activation of protein kinase C accelerates internalization of transferrin receptor but not of major histocompatibility complex class I, independent of their phosphorylation status. J Biol Chem, 1992. 267(31): p. 22490-5.

143. Gratton, S., et al., Molecular analysis of the cytoplasmic domain of CD4: overlapping but noncompetitive requirement for lck association and downregulation by Nef. J Immunol, 1996. 157(8): p. 3305-11.

144. Janardhan, A., et al., HIV-1 Nef binds the DOCK2-ELMO1 complex to activate rac and inhibit lymphocyte chemotaxis. PLoS Biol, 2004. 2(1): p. E6.

145. Janvier, K., et al., Nef-induced CD4 downregulation: a diacidic sequence in human immunodeficiency virus type 1 Nef does not function as a protein 
sorting motif through direct binding to beta-COP. J Virol, 2001. 75(8): p. 3971 6.

146. Le Gall, S., et al., Distinct trafficking pathways mediate Nef-induced and clathrin-dependent major histocompatibility complex class I down-regulation. J Virol, 2000. 74(19): p. 9256-66.

147. Pelchen-Matthews, A., I.J. Parsons, and M. Marsh, Phorbol ester-induced downregulation of $\mathrm{CD} 4$ is a multistep process involving dissociation from p56lck, increased association with clathrin-coated pits, and altered endosomal sorting. J Exp Med, 1993. 178(4): p. 1209-22.

148. Costa, L.J., et al., Nef binds p6* in GagPol during replication of human immunodeficiency virus type 1. J Virol, 2004. 78(10): p. 5311-23.

149. Benichou, S., et al., Physical interaction of the HIV-1 Nef protein with betaCOP, a component of non-clathrin-coated vesicles essential for membrane traffic. J Biol Chem, 1994. 269(48): p. 30073-6.

150. Fauci, A.S., The human immunodeficiency virus: infectivity and mechanisms of pathogenesis. Science, 1988. 239(4840): p. 617-22.

151. Janvier, K., et al., HIV-1 Nef stabilizes the association of adaptor protein complexes with membranes. J Biol Chem, 2003. 278(10): p. 8725-32.

152. Lee, C.H., et al., A single amino acid in the SH3 domain of Hck determines its high affinity and specificity in binding to HIV-1 Nef protein. EMBO J, 1995. 14(20): p. 5006-15.

153. Baur, A.S., et al., The N-terminus of Nef from HIV-1/SIV associates with a protein complex containing Lck and a serine kinase. Immunity, 1997. 6(3): p. 283-91.

154. Sandrin, V. and F.L. Cosset, Intracellular versus cell surface assembly of retroviral pseudotypes is determined by the cellular localization of the viral glycoprotein, its capacity to interact with Gag, and the expression of the Nef protein. J Biol Chem, 2006. 281(1): p. 528-42.

155. Jin, Y.J., et al., Lysine 144, a ubiquitin attachment site in HIV-1 Nef, is required for Nef-mediated CD4 down-regulation. J Immunol, 2008. 180(12): p. 7878-86. 
156. Tokunaga, K., et al., Inhibition of human immunodeficiency virus type 1 virion entry by dominant-negative Hck. J Virol, 1998. 72(7): p. 6257-9.

157. Janvier, K., et al., Recognition of dileucine-based sorting signals from HIV-I Nef and LIMP-II by the AP-1 gamma-sigma1 and AP-3 delta-sigma3 hemicomplexes. J Cell Biol, 2003. 163(6): p. 1281-90.

158. Stewart, S.J., J. Fujimoto, and R. Levy, Human Thmphocytes and monocytes bear the same Leu-3(T4) antigen. J Immunol, 1986. 136(10): p. 3773-8.

159. Thomas, Y., L. Rogozinski, and L. Chess, Relationship between human T cell functional heterogeneity and human $T$ cell surface molecules. Immunol Rev, 1983. 74: p. 113-28.

160. Doyle, C. and J.L. Strominger, Interaction between CD4 and class II MHC molecules mediates cell adhesion. Nature, 1987. 330(6145): p. 256-9.

161. Rosoff, P.M., S.J. Burakoff, and J.L. Greenstein, The role of the L3T4 molecule in mitogen and antigen-activated signal transduction. Cell, 1987. 49(6): p. 84553.

162. Dalgleish, A.G., et al., The CD4 (T4) antigen is an essential component of the receptor for the AIDS retrovirus. Nature, 1984. 312(5996): p. 763-7.

163. Shaw, A.S., et al., Short related sequences in the cytoplasmic domains of CD4 and CD8 mediate binding to the amino-terminal domain of the p56lck tyrosine protein kinase. Mol Cell Biol, 1990. 10(5): p. 1853-62.

164. Turner, J.M., et al., Interaction of the unique $N$-terminal region of tyrosine kinase p56lck with cytoplasmic domains of CD4 and CD8 is mediated by cysteine motifs. Cell, 1990. 60(5): p. 755-65.

165. Roeth, J.F. and K.L. Collins, Human immunodeficiency virus type 1 Nef: adapting to intracellular trafficking pathways. Microbiol Mol Biol Rev, 2006. 70(2): p. 548-63.

166. Robinson, M.S., Adaptable adaptors for coated vesicles. Trends Cell Biol, 2004. 14(4): p. 167-74.

167. Doray, B., et al., Cooperation of GGAs and AP-1 in packaging MPRs at the trans-Golgi network. Science, 2002. 297(5587): p. 1700-3. 
168. Peden, A.A., et al., Localization of the AP-3 adaptor complex defines a novel endosomal exit site for lysosomal membrane proteins. J Cell Biol, 2004. 164(7): p. 1065-76.

169. Traub, L.M., Sorting it out: AP-2 and alternate clathrin adaptors in endocytic cargo selection. J Cell Biol, 2003. 163(2): p. 203-8.

170. Waguri, S., et al., Visualization of TGN to endosome trafficking through fluorescently labeled MPR and AP-1 in living cells. Mol Biol Cell, 2003. 14(1): p. 142-55.

171. Marsh, M. and H.T. McMahon, The structural era of endocytosis. Science, 1999. 285(5425): p. 215-20.

172. Hirst, J., et al., EpsinR: an ENTH domain-containing protein that interacts with AP-1. Mol Biol Cell, 2003. 14(2): p. 625-41.

173. Wasiak, S., et al., Enthoprotin: a novel clathrin-associated protein identified through subcellular proteomics. J Cell Biol, 2002. 158(5): p. 855-62.

174. De Matteis, M.A. and A. Godi, PI-loting membrane traffic. Nat Cell Biol, 2004. 6(6): p. 487-92.

175. Odorizzi, G., C.R. Cowles, and S.D. Emr, The AP-3 complex: a coat of many colours. Trends Cell Biol, 1998. 8(7): p. 282-8.

176. Morel, N., Neurotransmitter release: the dark side of the vacuolar-H+ATPase. Biol Cell, 2003. 95(7): p. 453-7.

177. Smith, A.N., et al., Revised nomenclature for mammalian vacuolar-type $\mathrm{H+}$ ATPase subunit genes. Mol Cell, 2003. 12(4): p. 801-3.

178. Mandic, R., et al., Negative factor from SIV binds to the catalytic subunit of the $V$-ATPase to internalize CD4 and to increase viral infectivity. Mol Biol Cell, 2001. 12(2): p. 463-73.

179. Garcia, J.V. and A.D. Miller, Serine phosphorylation-independent downregulation of cell-surface CD4 by nef. Nature, 1991. 350(6318): p. 508-11.

180. Barlowe, C., Traffic COPs of the early secretory pathway. Traffic, 2000. 1(5): p. 371-7. 
181. Aniento, $F$., et al., An endosomal beta COP is involved in the pH-dependent formation of transport vesicles destined for late endosomes. J Cell Biol, 1996. 133(1): p. 29-41.

182. Daro, E., et al., Inhibition of endosome function in $\mathrm{CHO}$ cells bearing a temperature-sensitive defect in the coatomer (COPI) component epsilon-COP. J Cell Biol, 1997. 139(7): p. 1747-59.

183. Gu, F., et al., Functional dissection of COP-I subunits in the biogenesis of multivesicular endosomes. J Cell Biol, 1997. 139(5): p. 1183-95.

184. Beron, W., et al., Recruitment of coat-protein-complex proteins on to phagosomal membranes is regulated by a brefeldin A-sensitive ADPribosylation factor. Biochem J, 2001. 355(Pt 2): p. 409-15.

185. Botelho, R.J., et al., Role of COPI in phagosome maturation. J Biol Chem, 2000. 275(21): p. 15717-27.

186. Johannes, L., et al., Effects of HIV-1 Nef on retrograde transport from the plasma membrane to the endoplasmic reticulum. Traffic, 2003. 4(5): p. 323-32.

187. Llorente, A., et al., Induction of direct endosome to endoplasmic reticulum transport in Chinese hamster ovary (CHO) cells (LdlF) with a temperaturesensitive defect in epsilon-coatomer protein (epsilon-COP). J Biol Chem, 2003. 278(37): p. 35850-5.

188. Faure, J., et al., ARF1 regulates Nef-induced CD4 degradation. Curr Biol, 2004. 14(12): p. 1056-64.

189. Madrid, R., et al., Nef-induced alteration of the early/recycling endosomal compartment correlates with enhancement of $\mathrm{HIV}-1$ infectivity. J Biol Chem, 2005. 280(6): p. 5032-44.

190. Sanfridson, A., S. Hester, and C. Doyle, Nef proteins encoded by human and simian immunodeficiency viruses induce the accumulation of endosomes and lysosomes in human T cells. Proc Natl Acad Sci U S A, 1997. 94(3): p. 873-8.

191. Stumptner-Cuvelette, P., et al., Human immunodeficiency virus-1 Nef expression induces intracellular accumulation of multivesicular bodies and major histocompatibility complex class II complexes: potential role of phosphatidylinositol 3-kinase. Mol Biol Cell, 2003. 14(12): p. 4857-70. 
192. Vigerust, D.J., B.S. Egan, and V.L. Shepherd, HIV-1 Nef mediates posttranslational down-regulation and redistribution of the mannose receptor. $J$ Leukoc Biol, 2005. 77(4): p. 522-34.

193. Ornelas, S.S., Estudo da Relevância Fisiológica da tiosterase humana II (hTEII) na modulação de CD4, mediada pela proteína Nef HIV-1., in PósGraduação em Patologia Molecular. 2007, Universidade de Brasília: BrasíliaDF.p. 83.

194. Schmid, E.M., et al., Role of the AP2 beta-appendage hub in recruiting partners for clathrin-coated vesicle assembly. PLoS Biol, 2006. 4(9): p. e262.

195. Chen, H., et al., Epsin is an EH-domain-binding protein implicated in clathrinmediated endocytosis. Nature, 1998. 394(6695): p. 793-7.

196. Kasai, K., et al., Dynamin II is involved in endocytosis but not in the formation of transport vesicles from the trans-Golgi network. J Biochem, 1999. 125(4): p. 780-9.

197. Quentin, Y., Fusion of a free left Alu monomer and a free right Alu monomer at the origin of the Alu family in the primate genomes. Nucleic Acids Res, 1992. 20(3): p. 487-93.

198. Vila-Coro, A.J., et al., Characterization of RANTES-and aminooxypentaneRANTES-triggered desensitization signals reveals differences in recruitment of the G protein-coupled receptor complex. J Immunol, 1999. 163(6): p. 3037-44.

199. Shoemaker, B.A. and A.R. Panchenko, Deciphering protein-protein interactions. Part I. Experimental techniques and databases. PLoS Comput Biol, 2007. 3(3): p. e42.

200. Piehler, J., New methodologies for measuring protein interactions in vivo and in vitro. Curr Opin Struct Biol, 2005. 15(1): p. 4-14.

201. Selvin, P.R., The renaissance of fluorescence resonance energy transfer. Nat Struct Biol, 2000. 7(9): p. 730-4.

202. Chan, F.K., et al., Fluorescence resonance energy transfer analysis of cell surface receptor interactions and signaling using spectral variants of the green fluorescent protein. Cytometry, 2001. 44(4): p. 361-8. 
203. Siegel, R.M., et al., Measurement of molecular interactions in living cells by fluorescence resonance energy transfer between variants of the green fluorescent protein. Sci STKE, 2000. 2000(38): p. pll.

204. Banning, C., Votteler, J., Hoffmann, D., Koppensteiner, H., Warmer, M., Reimer, R., Kirchhoff, F., Schubert, U., Hauber, J. and Schindler, M., A Flow Cytometry-based FRET Assay to Identify and Analyse Protein-Protein Interactions in Living Cells. . PLoS ONE 2010. in press.

205. Fire, A., et al., Potent and specific genetic interference by double-stranded RNA in Caenorhabditis elegans. Nature, 1998. 391(6669): p. 806-11.

206. Ketting, R.F., et al., Mut-7 of C. elegans, required for transposon silencing and RNA interference, is a homolog of Werner syndrome helicase and RNaseD. Cell, 1999. 99(2): p. 133-41.

207. Tomari, Y. and P.D. Zamore, Perspective: machines for RNAi. Genes Dev, 2005. 19(5): p. 517-29.

208. Elbashir, S.M., W. Lendeckel, and T. Tuschl, RNA interference is mediated by 21- and 22-nucleotide RNAs. Genes Dev, 2001. 15(2): p. 188-200.

209. Jacque, J.M., K. Triques, and M. Stevenson, Modulation of HIV-1 replication by RNA interference. Nature, 2002. 418(6896): p. 435-8.

210. Novina, C.D., et al., siRNA-directed inhibition of HIV-1 infection. Nat Med, 2002. 8(7): p. 681-6.

211. Brisibe, E.A., et al., RNA interference: potentials for the prevention of HIV infections and the challenges ahead. Trends Biotechnol, 2003. 21(7): p. 306-11.

212. Brown, A.E. and F. Catteruccia, Toward silencing the burden of malaria: progress and prospects for RNAi-based approaches. Biotechniques, 2006. Suppl: p. 38-44.

213. Fritz, J.H., S.E. Girardin, and D.J. Philpott, Innate immune defense through RNA interference. Sci STKE, 2006. 2006(339): p. pe27.

214. Simmons, K.J., et al., Stable RNA interference of host thrombospondin-1 blocks Trypanosoma cruzi infection. FEBS Lett, 2006. 580(9): p. 2365-70.

215. Tong, A.W., Small RNAs and non-small cell lung cancer. Curr Mol Med, 2006. 6(3): p. 339-49. 
216. Cohen, M.S., Preventing transmission of HIV: a biological and medical perspective. AIDS Patient Care STDS, 2001. 15(8): p. 427-9.

217. Chun, T.W., et al., Early establishment of a pool of latently infected, resting CD4(+) T cells during primary HIV-1 infection. Proc Natl Acad Sci U S A, 1998. 95(15): p. 8869-73.

218. Pierson, T., J. McArthur, and R.F. Siliciano, Reservoirs for HIV-1: mechanisms for viral persistence in the presence of antiviral immune responses and antiretroviral therapy. Annu Rev Immunol, 2000. 18: p. 665-708.

219. Blankson, J.N., D. Persaud, and R.F. Siliciano, The challenge of viral reservoirs in HIV-1 infection. Annu Rev Med, 2002. 53: p. 557-93.

220. Carl, S., et al., Modulation of different human immunodeficiency virus type 1 Nef functions during progression to AIDS. J Virol, 2001. 75(8): p. 3657-65.

221. Learmont, J.C., et al., Immunologic and virologic status after 14 to 18 years of infection with an attenuated strain of HIV-1. A report from the Sydney Blood Bank Cohort. N Engl J Med, 1999. 340(22): p. 1715-22.

222. Pham, H.M., et al., Lentiviral vectors interfering with virus-induced CD4 downmodulation potently block human immunodeficiency virus type 1 replication in primary lymphocytes. J Virol, 2004. 78(23): p. 13072-81.

223. Koppensteiner, H., et al., Lentiviral Nef suppresses iron uptake in a strain specific manner through inhibition of Transferrin endocytosis. Retrovirology. 11: p. 1.

224. Hachet-Haas, M., et al., FRET and colocalization analyzer--a method to validate measurements of sensitized emission FRET acquired by confocal microscopy and available as an ImageJ Plug-in. Microsc Res Tech, 2006. 69(12): p. 941-56.

225. Lama, J., The physiological relevance of CD4 receptor down-modulation during HIV infection. Curr HIV Res, 2003. 1(2): p. 167-84.

226. Levesque, K., et al., Role of CD4 receptor down-regulation during HIV-1 infection. Curr HIV Res, 2004. 2(1): p. 51-9.

227. Piguet, V., et al., Nef-induced CD4 degradation: a diacidic-based motif in Nef functions as a lysosomal targeting signal through the binding of beta-COP in endosomes. Cell, 1999. 97(1): p. 63-73. 
228. Lu, X., et al., Interactions between HIV1 Nef and vacuolar ATPase facilitate the internalization of CD4. Immunity, 1998. 8(5): p. 647-56.

229. Hunt, M.C., et al., Characterization of an acyl-coA thioesterase that functions as a major regulator of peroxisomal lipid metabolism. J Biol Chem, 2002. 277(2): p. 1128-38.

230. Hunt, M.C., et al., A revised nomenclature for mammalian acyl-CoA thioesterases/hydrolases. J Lipid Res, 2005. 46(9): p. 2029-32.

231. Liu, L.X., et al., Mutation of a conserved residue (D123) required for oligomerization of human immunodeficiency virus type 1 Nef protein abolishes interaction with human thioesterase and results in impairment of Nef biological functions. J Virol, 2000. 74(11): p. 5310-9.

232. Westin, M.A., S.E. Alexson, and M.C. Hunt, Molecular cloning and characterization of two mouse peroxisome proliferator-activated receptor alpha (PPARalpha)-regulated peroxisomal acyl-CoA thioesterases. J Biol Chem, 2004. 279(21): p. 21841-8.

233. Jones, J.M., et al., Identification of peroxisomal acyl-CoA thioesterases in yeast and humans. J Biol Chem, 1999. 274(14): p. 9216-23.

234. Hunt, M.C., et al., Analysis of the mouse and human acyl-CoA thioesterase (ACOT) gene clusters shows that convergent, functional evolution results in a reduced number of human peroxisomal ACOTs. FASEB J, 2006. 20(11): p. 1855-64.

235. Lu, J.Y., L.A. Verkruyse, and S.L. Hofmann, Lipid thioesters derived from acylated proteins accumulate in infantile neuronal ceroid lipofuscinosis: correction of the defect in lymphoblasts by recombinant palmitoyl-protein thioesterase. Proc Natl Acad Sci U S A, 1996. 93(19): p. 10046-50.

236. Wei, X., et al., Negative effect of the M184V mutation in HIV-1 reverse transcriptase on initiation of viral DNA synthesis. Virology, 2003. 311(1): p. 202-12.

237. Glushakova, S., et al., CD4 down-modulation by human immunodeficiency virus type 1 Nef correlates with the efficiency of viral replication and with CD4(+) T-cell depletion in human lymphoid tissue ex vivo. J Virol, 2001. 75(21): p. 10113-7. 
238. Schindler, M., et al., Nef-mediated suppression of $T$ cell activation was lost in a lentiviral lineage that gave rise to HIV-1. Cell, 2006. 125(6): p. 1055-67.

239. Geyer, M., O.T. Fackler, and B.M. Peterlin, Subunit H of the V-ATPase involved in endocytosis shows homology to beta-adaptins. Mol Biol Cell, 2002. 13(6): p. 2045-56.

240. Owen, D.J., B.M. Collins, and P.R. Evans, Adaptors for clathrin coats: structure and function. Annu Rev Cell Dev Biol, 2004. 20: p. 153-91.

241. Schaefer, M.R., et al., HIV-1 Nef targets MHC-I and CD4 for degradation via a final common beta-COP-dependent pathway in T cells. PLoS Pathog, 2008. 4(8): p. e1000131.

242. Mangasarian, A., et al., Nef-induced CD4 and major histocompatibility complex class I (MHC-I) down-regulation are governed by distinct determinants: $N$-terminal alpha helix and proline repeat of Nef selectively regulate MHC-I trafficking. J Virol, 1999. 73(3): p. 1964-73.

243. Roeth, J.F., et al., HIV-1 Nef disrupts MHC-I trafficking by recruiting AP-1 to the MHC-I cytoplasmic tail. J Cell Biol, 2004. 167(5): p. 903-13.

244. Schindler, M., et al., Down-modulation of mature major histocompatibility complex class II and up-regulation of invariant chain cell surface expression are well-conserved functions of human and simian immunodeficiency virus nef alleles. J Virol, 2003. 77(19): p. 10548-56.

245. Sol-Foulon, N., et al., The effects of HIV-1 Nef on CD4 surface expression and viral infectivity in lymphoid cells are independent of rafts. J Biol Chem, 2004. 279(30): p. 31398-408.

246. Lindwasser, $O . W$., et al., A diacidic motif in human immunodeficiency virus type 1 Nef is a novel determinant of binding to AP-2. J Virol, 2008. 82(3): p. 1166-74.

247. Markle, T.J., M. Philip, and M.A. Brockman, HIV-1 Nef and T-cell activation: a history of contradictions. Future Virol. 8(4).

248. Rose, J.J., et al., CD4 down-regulation by HIV-1 and simian immunodeficiency virus (SIV) Nef proteins involves both internalization and intracellular retention mechanisms. J Biol Chem, 2005. 280(9): p. 7413-26. 
249. Stove, V., et al., Human immunodeficiency virus Nef induces rapid internalization of the T-cell coreceptor CD8alphabeta. J Virol, 2005. 79(17): p. 11422-33.

250. Leonard, J.A., et al., HIV-1 Nef disrupts intracellular trafficking of major histocompatibility complex class I, CD4, CD8, and CD28 by distinct pathways that share common elements. J Virol. 85(14): p. 6867-81.

251. Kim, Y.H., et al., HIV-1 Nef plays an essential role in two independent processes in CD4 down-regulation: dissociation of the CD4-p56(lck) complex and targeting of CD4 to lysosomes. Virology, 1999. 257(1): p. 208-19.

252. Marracci, G.H., et al., Lipoic acid downmodulates CD4 from human T lymphocytes by dissociation of p56(Lck). Biochem Biophys Res Commun, 2006. 344(3): p. 963-71.

253. Laguette, $N$., et al., Nef-induced CD4 endocytosis in human immunodeficiency virus type 1 host cells: role of p56lck kinase. J Virol, 2009. 83(14): p. 7117-28.

254. Burtey, A., et al., Dynamic interaction of HIV-1 Nef with the clathrin-mediated endocytic pathway at the plasma membrane. Traffic, 2007. 8(1): p. 61-76.

255. Foti, M., et al., Nef-mediated clathrin-coated pit formation. J Cell Biol, 1997. 139(1): p. 37-47.

256. Mariani, R. and J. Skowronski, CD4 down-regulation by nef alleles isolated from human immunodeficiency virus type 1-infected individuals. Proc Natl Acad Sci U S A, 1993. 90(12): p. 5549-53.

257. Skowronski, J., D. Parks, and R. Mariani, Altered T cell activation and development in transgenic mice expressing the HIV-1 nef gene. EMBO J, 1993. 12(2): p. 703-13.

258. Thoulouze, M.I., et al., Human immunodeficiency virus type-1 infection impairs the formation of the immunological synapse. Immunity, 2006. 24(5): p. 547-61.

259. Manninen, A., et al., Activation of NFAT-dependent gene expression by Nef: conservation among divergent Nef alleles, dependence on SH3 binding and membrane association, and cooperation with protein kinase $C$-theta. J Virol, 2001. 75(6): p. 3034-7. 
260. Iafrate, A.J., S. Bronson, and J. Skowronski, Separable functions of Nef disrupt two aspects of $T$ cell receptor machinery: CD4 expression and CD3 signaling. EMBO J, 1997. 16(4): p. 673-84.

261. Cohen, O.J. and A.S. Fauci, Current strategies in the treatment of HIV infection. Adv Intern Med, 2001. 46: p. 207-46.

262. Tiganos, E., et al., Structural and functional analysis of the membranespanning domain of the human immunodeficiency virus type 1 Vpu protein. Virology, 1998. 251(1): p. 96-107.

263. Binette, J. and E.A. Cohen, Recent advances in the understanding of HIV-1 Vpu accessory protein functions. Curr Drug Targets Immune Endocr Metabol Disord, 2004. 4(4): p. 297-307.

264. Crise, B., L. Buonocore, and J.K. Rose, CD4 is retained in the endoplasmic reticulum by the human immunodeficiency virus type 1 glycoprotein precursor. J Virol, 1990. 64(11): p. 5585-93.

265. Bour, S., U. Schubert, and K. Strebel, The human immunodeficiency virus type 1 Vpu protein specifically binds to the cytoplasmic domain of CD4: implications for the mechanism of degradation. J Virol, 1995. 69(3): p. 1510-20.

266. Strebel, K., HIV-1 Vpu - an ion channel in search of a job. Biochim Biophys Acta. 1838(4): p. 1074-81.

267. Coadou, G., et al., NMR studies of the phosphorylation motif of the HIV-1 protein Vpu bound to the F-box protein beta-TrCP. Biochemistry, 2003. 42(50): p. 14741-51.

268. Hsu, K., et al., Mutual functional destruction of HIV-1 Vpu and host TASK-1 channel. Mol Cell, 2004. 14(2): p. 259-67.

269. Varthakavi, V., et al., Identification of calcium-modulating cyclophilin ligand as a human host restriction to HIV-1 release overcome by Vpu. Nat Med, 2008. 14(6): p. 641-7.

270. Mitchell, R.S., et al., Vpu antagonizes BST-2-mediated restriction of HIV-1 release via beta-TrCP and endo-lysosomal trafficking. PLoS Pathog, 2009. 5(5): p.e1000450. 
271. Kelly, H., et al., Effects of HIV-1-induced CD1c and CD1d modulation and endogenous lipid presentation on CD1c-restricted T-cell activation. BMC Immunol. 14: $p .4$.

272. Alter, G., et al., HIV-1 adaptation to NK-cell-mediated immune pressure. Nature. 476(7358): p. 96-100.

273. Kramski, M., I. Stratov, and S.J. Kent, The role of HIV-specific antibodydependent cellular cytotoxicity in HIV prevention and the influence of the HIV1 Vpu protein. AIDS. 29(2): p. 137-44.

274. Shah, A.H., et al., Degranulation of natural killer cells following interaction with HIV-1-infected cells is hindered by downmodulation of NTB-A by Vpu. Cell Host Microbe. 8(5): p. 397-409.

275. Sandberg, J.K., et al., HIV-1 Vpu interference with innate cell-mediated immune mechanisms. Curr HIV Res. 10(4): p. 327-33.

276. Bour, S., et al., The human immunodeficiency virus type 1 Vpu protein inhibits NF-kappa B activation by interfering with beta TrCP-mediated degradation of Ikappa B. J Biol Chem, 2001. 276(19): p. 15920-8.

277. Strebel, K., HIV accessory proteins versus host restriction factors. Curr Opin Virol. 3(6): p. 692-9.

278. Hussain, A., et al., Human immunodeficiency virus type 1 Vpu protein interacts with CD74 and modulates major histocompatibility complex class II presentation. J Virol, 2008. 82(2): p. 893-902.

279. Schindler, M., et al., Vpu serine 52 dependent counteraction of tetherin is required for HIV-1 replication in macrophages, but not in ex vivo human lymphoid tissue. Retrovirology. 7: p. 1.

280. Goffinet, C., et al., HIV-1 antagonism of CD317 is species specific and involves Vpu-mediated proteasomal degradation of the restriction factor. Cell Host Microbe, 2009. 5(3): p. 285-97.

281. Avila, M.M., et al., Two HIV-1 epidemics in Argentina: different genetic subtypes associated with different risk groups. J Acquir Immune Defic Syndr, 2002. 29(4): p. 422-6.

282. Carr, J.K., et al., Diverse BF recombinants have spread widely since the introduction of HIV-1 into South America. AIDS, 2001. 15(15): p. F41-7. 
283. Dilernia, D.A., et al., HIV type 1 genetic diversity surveillance among newly diagnosed individuals from 2003 to 2005 in Buenos Aires, Argentina. AIDS Res Hum Retroviruses, 2007. 23(10): p. 1201-7.

284. Gomez Carrillo, M., et al., Mother-to-child HIV type 1 transmission in Argentina: $B F$ recombinants have predominated in infected children since the mid-1980s. AIDS Res Hum Retroviruses, 2002. 18(7): p. 477-83.

285. Pando, M.A., et al., First report of an HIV-1 triple recombinant of subtypes B, $C$ and $F$ in Buenos Aires, Argentina. Retrovirology, 2006. 3: p. 59.

286. Thomson, M.M., et al., Analysis of near full-length genome sequences of HIV type 1 BF intersubtype recombinant viruses from Brazil reveals their independent origins and their lack of relationship to CRF12_BF. AIDS Res Hum Retroviruses, 2004. 20(10): p. 1126-33.

287. Thomson, M.M., et al., Widespread circulation of a B/F intersubtype recombinant form among $\mathrm{HIV}$-1-infected individuals in Buenos Aires, Argentina. AIDS, 2000. 14(7): p. 897-9.

288. De Candia, C., et al., Viral replication is enhanced by an HIV-1 intersubtype recombination-derived Vpu protein. Virol J. 7: p. 259.

289. Rossenkhan, $R$., et al., Viral diversity and diversification of major nonstructural genes vif, vpr, vpu, tat exon 1 and rev exon 1 during primary $\mathrm{HIV}-\mathrm{I}$ subtype C infection. PLoS One. 7(5): p. e35491.

290. Michael, N.L., Host genetic influences on HIV-1 pathogenesis. Curr Opin Immunol, 1999. 11(4): p. 466-74.

291. Pantaleo, G., et al., Studies in subjects with long-term nonprogressive human immunodeficiency virus infection. N Engl J Med, 1995. 332(4): p. 209-16.

292. Deeks, S.G. and B.D. Walker, Human immunodeficiency virus controllers: mechanisms of durable virus control in the absence of antiretroviral therapy. Immunity, 2007. 27(3): p. 406-16.

293. Lambotte, O., et al., HIV controllers: a homogeneous group of HIV-1-infected patients with spontaneous control of viral replication. Clin Infect Dis, 2005. 41(7): $p$. 1053-6.

294. Betts, M.R., et al., HIV nonprogressors preferentially maintain highly functional HIV-specific CD8+T cells. Blood, 2006. 107(12): p. $4781-9$. 
295. Lama, J. and V. Planelles, Host factors influencing susceptibility to HIV infection and AIDS progression. Retrovirology, 2007. 4: p. 52.

296. Simm, M., The innate cellular responses to HIV-1 invasion: emerging molecules of ancient defense mechanisms. Arch Immunol Ther Exp (Warsz), 2007. 55(3): p. 131-8.

297. Brass, A.L., et al., Identification of host proteins required for HIV infection through a functional genomic screen. Science, 2008. 319(5865): p. 921-6.

298. Collins, K.L. and D. Baltimore, HIV's evasion of the cellular immune response. Immunol Rev, 1999. 168: p. 65-74.

299. Stremlau, M., et al., The cytoplasmic body component TRIM5alpha restricts HIV-1 infection in Old World monkeys. Nature, 2004. 427(6977): p. 848-53.

300. Coffin, J.M., HIV population dynamics in vivo: implications for genetic variation, pathogenesis, and therapy. Science, 1995. 267(5197): p. 483-9.

301. Overbaugh, J. and C.R. Bangham, Selection forces and constraints on retroviral sequence variation. Science, 2001. 292(5519): p. 1106-9.

302. Sheehy, A.M., et al., Isolation of a human gene that inhibits HIV-1 infection and is suppressed by the viral Vif protein. Nature, 2002. 418(6898): p. 646-50.

303. Weiss, R.A., How does HIV cause AIDS? Science, 1993. 260(5112): p. 1273-9.

304. Kremb, S., et al., EASY-HIT: HIV full-replication technology for broad discovery of multiple classes of HIV inhibitors. Antimicrob Agents Chemother. 54(12): p. 5257-68.

305. Jones, J., et al., Optimization of HIV-1 infectivity assays. Biotechniques, 2007. 43(5): p. 589-90, $592,594$.

306. Helfer, M., et al., The root extract of the medicinal plant Pelargonium sidoides is a potent HIV-1 attachment inhibitor. PLoS One. 9(1): p. e87487.

307. Altschul, S.F., et al., Basic local alignment search tool. J Mol Biol, 1990. 215(3): p. 403-10.

308. Thompson, J.D., D.G. Higgins, and T.J. Gibson, CLUSTAL W: improving the sensitivity of progressive multiple sequence alignment through sequence 
weighting, position-specific gap penalties and weight matrix choice. Nucleic Acids Res, 1994. 22(22): p. 4673-80.

309. Hill, M.S., et al., Modulation of the severe CD4+ T-cell loss caused by a pathogenic simian-human immunodeficiency virus by replacement of the subtype B vpu with the vpu from a subtype C HIV-1 clinical isolate. Virology, 2008. 371(1): p. 86-97.

310. Roy, N., et al., Mechanisms underlying HIV-1 Vpu-mediated viral egress. Front Microbiol. 5: p. 177.

311. Kuhl, B.D., et al., Tetherin restricts direct cell-to-cell infection of HIV-1. Retrovirology. 7: p. 115.

312. Bour, S. and K. Strebel, The HIV-1 Vpu protein: a multifunctional enhancer of viral particle release. Microbes Infect, 2003. 5(11): p. 1029-39.

313. Akari, $H$., et al., The human immunodeficiency virus type 1 accessory protein $V$ pu induces apoptosis by suppressing the nuclear factor kappaB-dependent expression of antiapoptotic factors. J Exp Med, 2001. 194(9): p. 1299-311.

314. Rawson, P.M., et al., Cross-presentation of caspase-cleaved apoptotic self antigens in HIV infection. Nat Med, 2007. 13(12): p. 1431-9.

315. Grossman, Z., et al., Pathogenesis of HIV infection: what the virus spares is as important as what it destroys. Nat Med, 2006. 12(3): p. 289-95.

316. Arias, J.F., et al., Tetherin antagonism by Vpu protects $H I V$-infected cells from antibody-dependent cell-mediated cytotoxicity. Proc Natl Acad Sci U S A. 111(17): p. 6425-30.

317. Alvarez, R.A., et al., HIV-1 Vpu antagonism of tetherin inhibits antibodydependent cellular cytotoxic responses by natural killer cells. J Virol. 88(11): p. 6031-46. 


\section{Capítulo 7. Anexo}




\subsection{Alinhamento das proteínas celulares fusionadas}

\section{$\beta-\operatorname{COP}:$}

1270

3-COR_WT MTAMENVCYT LINVPMDSEP PSEISLKNDL EKGDVKSKTE ALKKVIIMIL NGEKLPGLIM TIIRFVTRL

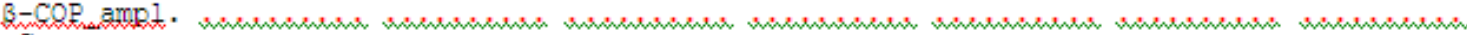

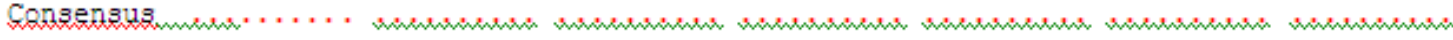

71

140

3-COR_WT DHTIKKLLLV FWEIVPKTTP DGRLLHEIL VCDAYRKDLQ HPNEFIRGST LRFLCKLKEA ELLEPLMPAI

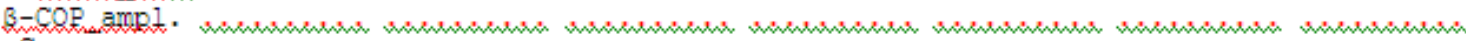

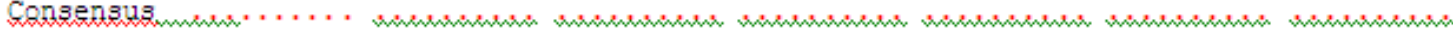

141210

3-COR WT RACLEHRHSY VRRNAVLAY TIYRNEEHLI PDAPELIHDF LVNEKDASCK RNAFMIIHA DQDRALDIS

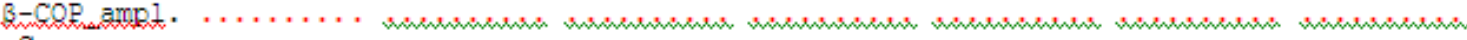

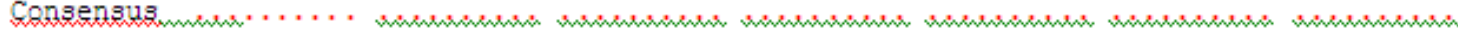

2112280

3-COR WI TCIDQVOTFG DILQLVIVEL IYKVCHANPS ERARFIRCIY NLIQSSSPAV KYEAMGTLVT LSSAPTAIKA

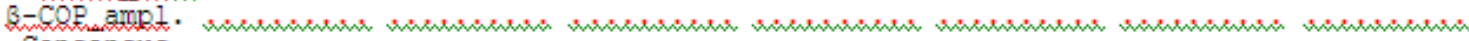

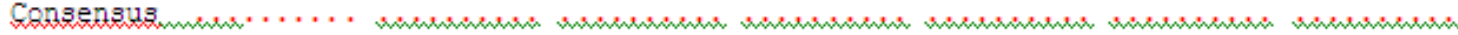

281350

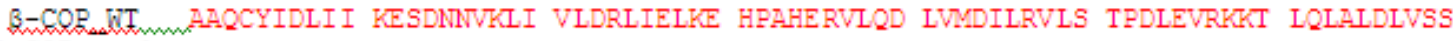

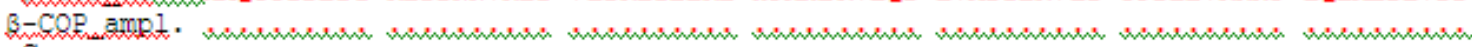

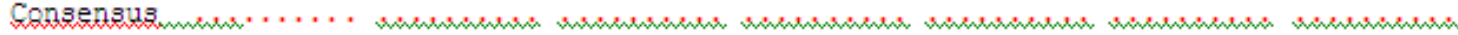

$351 \quad 420$

B-COR_WT RNVELVIVL KKEVIKTMNV SEHEDTDKYR QLLVRTLHSC SVRFPDMAN VIPVLMEFLS DMNEAMADV

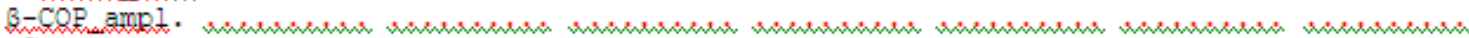

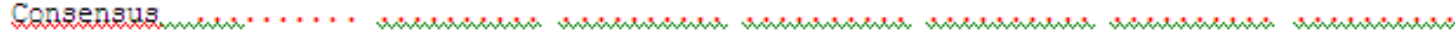

$421 \quad 490$

B-COR.WT LEFVREAIQR FDNLRMIIVE KMLEVFHAIK SVKIYRGALW ILGEYCSTKE DIQSVMTEIR RSLGEIPIVE

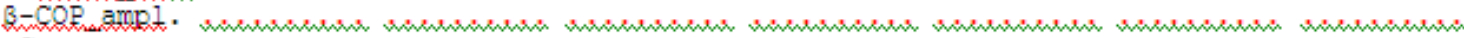

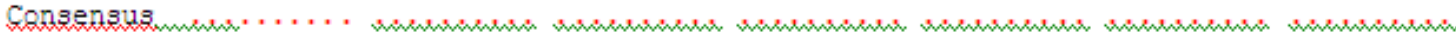

$491 \quad 560$

3-COP.WT SEIKKEAGEL KPEEEITVGP VQKLVTEMGT YATQSALSSS RPTKKEEDRP PLRGFLDGD FFVAASLAT

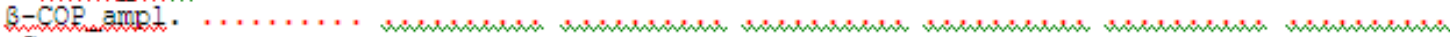

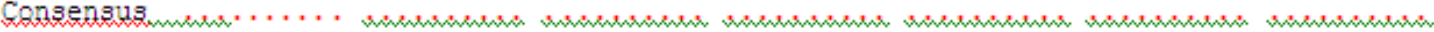

$561 \quad 630$

3-COR WT LTKIALRYVA LVQEKKKONS FVAEAMLIMA TILHLGKSSL PKKPITDDDV DRISLCLKVL SECSPLMNDI

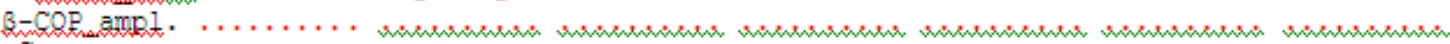

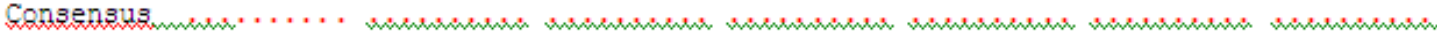

631

700

B-COR.WT FNKECRQSLS HMLSAKLEEE KLSQKKESEK RNVTVQPDDP ISFMQLTAKN EMTCKEDQFQ LSLLAMMGNT

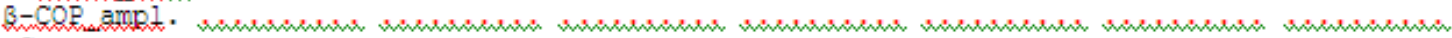

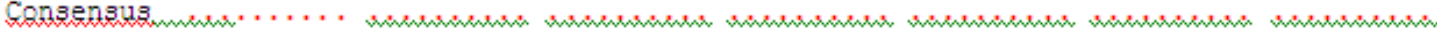

701

B-COR。WT ORKEAADPLA SKLNKVTOLT GFSDPVYAEA YVHVNQYDIV LDVLVMNQTS DTLONCTLEL ATLGDLKLVE

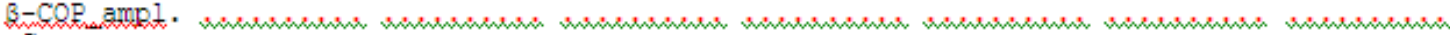

Consensus

77

840

3-COP.WT KPSPLTLAPH DFANIKANVK VASTENGIIF GNIVYDVSGA ASDRNCVVLS DIHIDIMDYI QPATCTDAEF

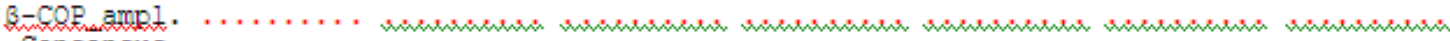

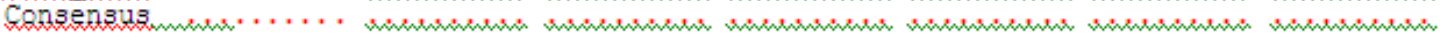

8412910

3-COR WT RQMWAEFEWE NKVTVITINV DLNDYLOHIL KSTNMKCLTP EKALSGYCGF MAMLYARSI FGEDALANS

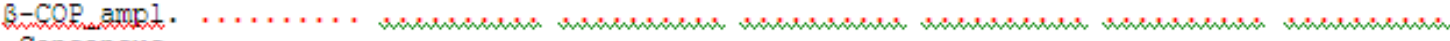

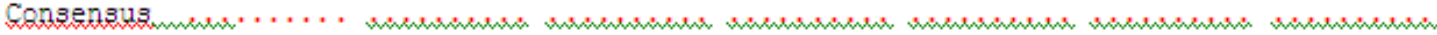

911

961

3-COR WT IEKPIHQGPD AMVTGHIRIR AKSQGMISL GDKINLSQKK TSI

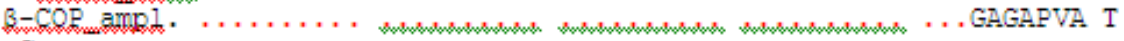

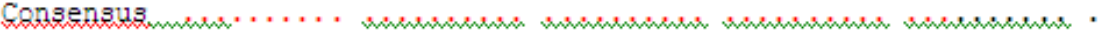


1270

API $\sigma$ WT MQFMLIFSRQ GKLRLQKWYV PLSDKEKKKI TRELVQTVLA RKPKMCSFLE WRDLKIVYKR YASLYFCCAI

A.P10_ampl.

Cons̄ensus

71

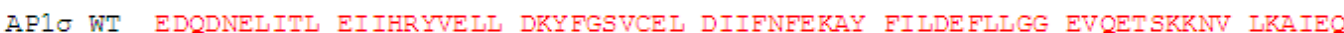

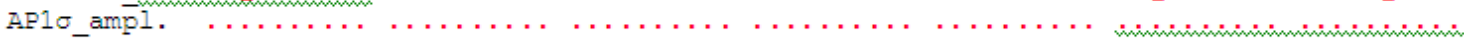

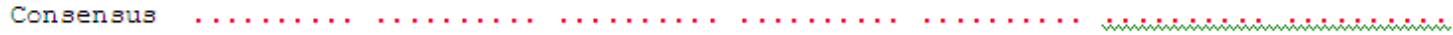

141

155

AP1 $\sigma$ WT OEEAETPRSW LEEIGLT

AP1 $\sigma$ ampl.

Consensus

AP $2 \mu$ :

A.P2 $\mu_{\text {WT }}$ AP2 $\mu$ ampl.

Consensus

$$
281
$$

211

KFGMNDKIVI EKQGKGTADE TSKSGKQSIA IDDCTFHQCV RLSKFDSERS ISFIPPDGEF ELMRYRTTKD

A.P $2 \mu$ WT A.P2 $2 \mu$ ampl. Consensus

AP2 $\mu$ WT A.P2 $\mu$ ampl. Consensus

WKIKRMAGMK ESQISAEIEL LPTNDKKKWA RPPISMNFEV PFAPSGLKVR YLKVFEPKLN YSDHDVIKWV

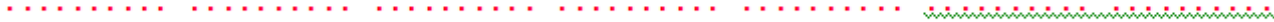

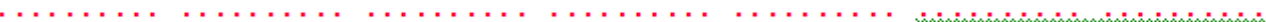

421 441

AP2 2 WT R RYTGRSGIYE TRC

A.P2 $\mu$ ampl.

Consensus

.......... - GAgAPVA T

AP2 $\sigma$ :

A.P2 $\sigma$ WT A.P2 $\sigma$ ampin. Consensus

AP2 $\sigma$ WT A.P2 $\sigma$ ampi 1 . Consensus

141

1170 MIRFILIQNR AGKTRLARWY MQEDDDEKQK LIEEVHAVVT VRDAKHTNFV EFRNFKIIYR RYAGLYFCIC

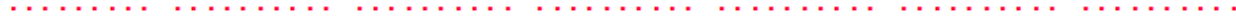
712140 VDVNDNNLAY LEAIHNFVEV LNEYFHNVCE LDLVFNFYKV YTVVDEMFLA GEIRETSQTK VLKQLLMLQS

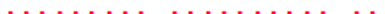

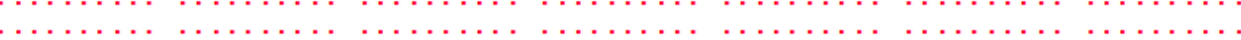

$141 \quad 150$

AP2 $\sigma_{-}$WT LE

AR2 $\sigma$ ampil. . GAGAPVAT

Consensus min. i......

\section{AP $3 \mu$ :}

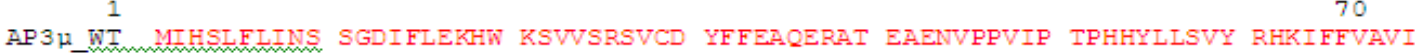

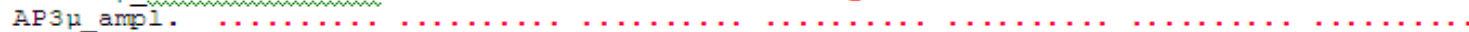
Consensu

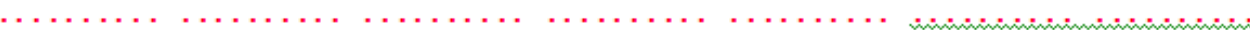

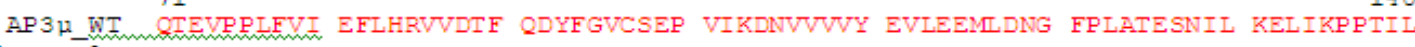
AP 3p_amp 1 . Consensus

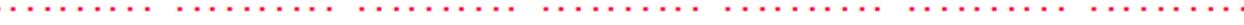

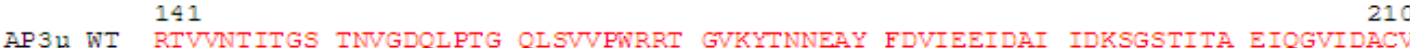

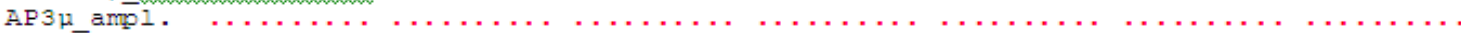

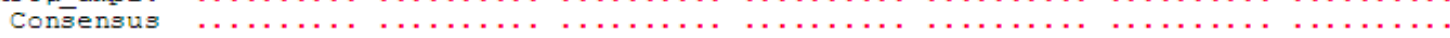

211280

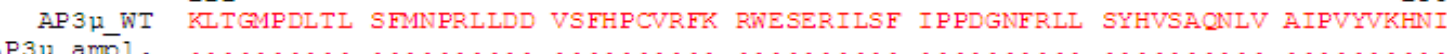
AP $3 \mu$ amp 1 . Cons̄ensus AP3 $\mu$ WT SFRDSSSLGR FEITVGPKQT MGKTIEGVTV TSQMPKGVLN MSLTPSQGTH TFDPVTKMLS WDVGKINPQK AP3 3 ampl. Consensus

AP $3 \mu$ WT AP 3 म Cons̄ensus

351
LPSLKGMSL QAGASKPDEN PTINLQFKIQ QLAISGLKVN RLDMYGEKYK PFKGIKYMTK AGKFQVRT

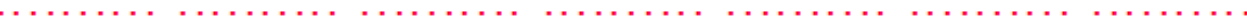

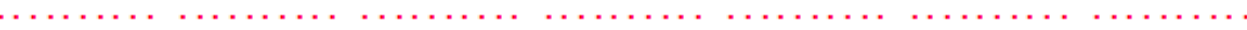

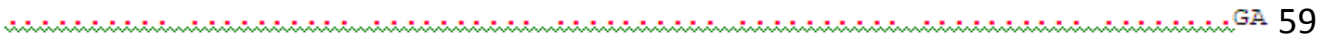

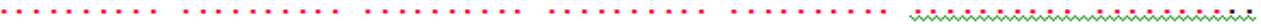


$\underline{\text { VH1: }}$

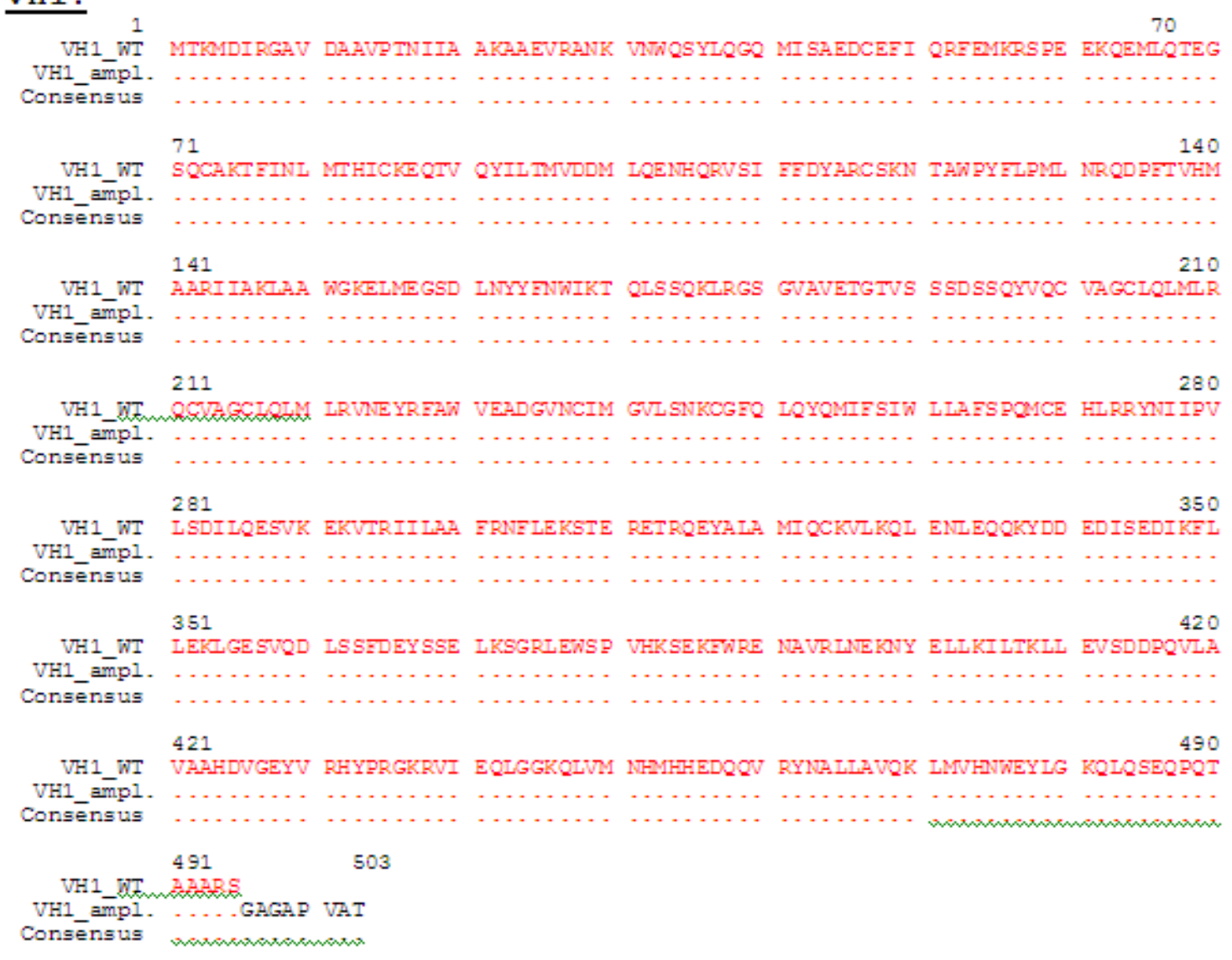

Anexo 7.1. Análise de homologia das sequências dos diferentes genes clonados nos vetores pECFP e pEYFP.. As sequencias dos diferentes genes clonados foi confirmada por analise de homologia em banco de dados NCBI. 


\subsection{Lista de vetores fusionado a CFP/YFP}

\begin{tabular}{|c|c|}
\hline Plasmídeo & Enzimas \\
\hline pECFP-CD4 & Age I and Nhe I \\
\hline pEYFP-CD4 & Age I and Nhe I \\
\hline pECFP-ßCOP & Age I and Nhe I \\
\hline pEYFP-ßCOP & Age I and Nhe I \\
\hline pECFP-AP $1 \sigma$ & Age I and Nhe I \\
\hline pEYFP-AP1 $\sigma$ & Age I and Nhe I \\
\hline pECFP-AP $2 \sigma$ & Age I and Nhe I \\
\hline pEYFP-AP2 $\sigma$ & Age I and Nhe I \\
\hline pECFP-AP $2 \mu$ & Age I and Nhe I \\
\hline $\mathrm{pEYFP-AP} 2 \mu$ & Age I and Nhe I \\
\hline pECFP-V1H & Age I and Nhe I \\
\hline pEYFP-V1H & Age I and Nhe I \\
\hline pECFP-Nef NL43 & Age I and Nhe I \\
\hline pEYFP-Nef NL43 & Age I and Nhe I \\
\hline pECFP-Nef NA7 & Age I and Nhe I \\
\hline pEYFP-Nef NA7 & Age I and Nhe I \\
\hline pECFP-hTEII & Age I and Nhe I \\
\hline pEYFP-hTEII & Age I and Nhe I \\
\hline pECFP-Nef 239 & Age I and Nhe I \\
\hline pEYFP-Nef 239 & Age I and Nhe I \\
\hline
\end{tabular}

Anexo 7.2. Lista de vetores de expressão com as proteínas celulares fusionados aos vetroes pECFP ou pEYFP. 


\subsection{Lista de plasmideos para produção de partículas virais}

\begin{tabular}{|c|c|}
\hline Plasmídeo & Enzima ou referência \\
\hline pNL-SIN-CMV-eGFP-hTEII-RNAi & $X b a \mathrm{I}$ and $\mathrm{ClaI}$ \\
\hline pNL-SIN-CMV-eGFP-ATP6V1H-RNAi & $X b a \mathrm{I}$ and $C l a \mathrm{I}$ \\
\hline pNL-SIN-CMV-eGFP-AP1 $\gamma$-RNAi & $X b a \mathrm{I}$ and $C l a \mathrm{I}$ \\
\hline pNL-SIN-CMV-eGFP-AP2 $\mu$-RNAi & $\mathrm{XbaI}$ and $\mathrm{ClaI}$ \\
\hline pNL-SIN-CMV-eGFP-AP3 $\mu$-RNAi & $X b a \mathrm{I}$ and $\mathrm{Cla \textrm {I }}$ \\
\hline pNL-SIN-CMV-eGFP-BCOP-RNAi & $X b a \mathrm{I}$ and $C l a \mathrm{I}$ \\
\hline pNL-SIN-CMV-eGFP-NEF RNAi & $X b a \mathrm{I}$ and $\mathrm{ClaI}$ \\
\hline pNL-SIN-CMV-eGFP-CD4-RNAi & $X b a \mathrm{I}$ and $C l a \mathrm{I}$ \\
\hline pNL-SIN-CMV-eGFP & BamHI and XhoI \\
\hline pCG-Tat & $M l u \mathrm{I}$ and $\mathrm{Xba \textrm {I }}$ \\
\hline pRSV-Rev & Dull et al., J. Virol., 1998 \\
\hline pCMV-VSV-G & Beyer et al.,J. Virol. 76, 2002 \\
\hline pBR_IRES_dsred2_Nef & $M l u \mathrm{I}$ and $H p a \mathrm{I}$ \\
\hline pBR-NefMac239_IRES_dsred2 & $M l u \mathrm{I}$ and $H p a \mathrm{I}$ \\
\hline pBR-NejNA7_IRES_dsred2 & $M l u \mathrm{I}$ and $H p a \mathrm{I}$ \\
\hline
\end{tabular}

7.3. Lista de vetores utilizados para a produção de partículas virais codificando RNAi para proteínas celulares. 